University of South Florida

DIGITAL COMMONS @ UNIVERSITY OF SOUTH FLORIDA
Digital Commons @ University of South Florida

$4-1-2015$

\title{
Identifying and Satisfying the Mobility Needs of North Dakota's Transit System
}

CUTR

Follow this and additional works at: https://digitalcommons.usf.edu/cutr_nctr

\author{
Recommended Citation \\ "Identifying and Satisfying the Mobility Needs of North Dakota's Transit System," National Center for \\ Transit Research (NCTR) Report No. CUTR-NCTR-RR-2015-02, Center for Urban Transportation Research, \\ University of South Florida, 2015. \\ DOI: https://doi.org/10.5038/CUTR-NCTR-RR-2015-02 \\ Available at: https://scholarcommons.usf.edu/cutr_nctr/76
}

This Technical Report is brought to you for free and open access by the National Center for Transit Research (NCTR) Archive (2000-2020) at Digital Commons @ University of South Florida. It has been accepted for inclusion in Research Reports by an authorized administrator of Digital Commons @ University of South Florida. For more information, please contact digitalcommons@usf.edu. 


\section{IDENTIFYING AND SATISFYING THE MOBILITY NEEDS OF NORTH DAKOTA'S TRANSIT SYSTEM}

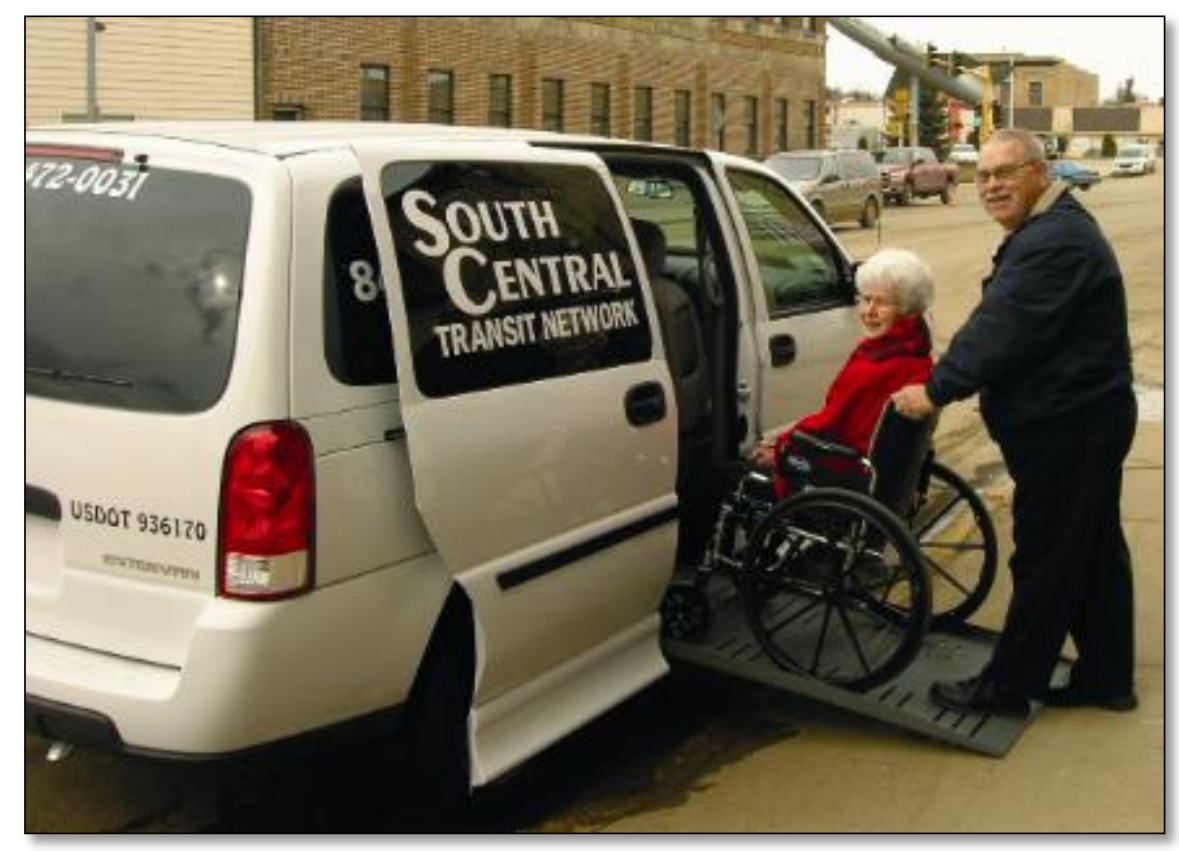

Prepared for:

North Dakota Department of Transportation

Prepared by:

Jeremy Mattson

Jill Hough, Ph.D.

Small Urban and Rural Transit Center

Upper Great Plains Transportation Institute

North Dakota State University, Fargo

UGPTI Department Publication No. 280

April 2015 


\section{Acknowledgements}

This research was funded by the North Dakota Department of Transportation. It was conducted by the Small Urban and Rural Transit Center, a program of the Upper Great Plains Transportation Institute at North Dakota State University.

The authors acknowledge the guidance provided by Stacey Hanson and Becky Hanson of the North Dakota Department of Transportation and the members of the project steering committee: Adam Altenburg, Fargo-Moorhead Metro COG; Dale Bergman, Cities Area Transit; Julie Bommelman, City of Fargo Metro Area Transit; Janis Cheney, AARP North Dakota; Darrell Francis, Souris Basin Transportation; Paul Grindeland, Valley Senior Services; Pat Hanson, South Central Adult Services; Colleen Rodakowski, Dickinson Public Transit; Steve Saunders, Bismarck-Mandan MPO; and Robin Werre, Bis-Man Transit Board. Thanks also to the transit agencies and human service agencies across the state for providing input. 


\section{ABSTRACT}

This study identifies the needs of transit agencies in North Dakota, gaps in transit service, and additional services and funding needed to meet current demand as well as projected future demand. Objectives are to construct a demographic profile of the state of North Dakota, develop a mobility needs index, describe existing levels of transit service across the state, identify base levels of required transit service and gaps in existing service, develop recommendations for meeting mobility needs, determine the level of funding needed to maintain the current level of service, and determine the level of funding needed to expand the existing level of service. North Dakota transit providers and human service agencies were surveyed to gather information about existing transit services, how well those services are meeting the needs of the state's residents, and the issues and challenges facing transit providers across the state. The study identified days and hours that transit service is currently being provided, rides provided per capita, and vehicle miles and vehicle hours per capita across the state. Target levels of transit service were identified, and the funding needed to reach those targets, including funds to cover increased operating expenses and vehicle purchases, was estimated. Projections were also made based on expected population growth. A series of recommendations were made regarding expansion of service, staffing needs, facilities and vehicle needs, and funding increases. Findings show a need for expansion of services across the state, especially in areas experiencing population growth, improvements in staffing, and additional vehicles. 


\section{EXECUTIVE SUMMARY}

The intent of this study is to provide North Dakota policy makers with a guide to future development of personal mobility options and to identify gaps that either exist now in mobility services or are likely to exist in the near future as the result of service modifications or changing demographics and population growth. The scope of the study includes local and regional passenger transportation.

Results can be used to identify programmatic and funding needs related to personal mobility, determine funding priorities for the use of state funds and federal funds under state control, and provide guidance to city and county governments for addressing personal mobility needs. Further, the data collected can be used by local and regional agencies to plan for new or revised local services. Lastly, the shrinking transit trust fund could mean reduced federal funding for North Dakota systems resulting in either reduced services or an increased requirement for state and local funding. This study illustrates how this uncertainty regarding federal funding could impact state funding needs.

The objective of this study is to determine the financial needs of the state transit providers. Specific tasks include the following:

1. Construct a demographic profile of the state of North Dakota

2. Develop a mobility needs index

3. Describe existing levels of transit service across the state

4. Identify base levels of required transit service and gaps in existing service

5. Develop recommendations for meeting mobility needs

6. Determine the level of funding needed to maintain the current level of service

7. Determine the level of funding needed to expand the existing level of service

\section{Population Growth, Demographic Profiles, and Mobility Needs Index}

Population growth and demographic trends are impacting the needs for public transportation services across the state. The estimated statewide population climbed to 723,393 in 2013 , an $8 \%$ increase from the 2010 census. Population is projected to increase to 841,820 by 2025, a $16 \%$ increase from 2013 estimates. Significant growth is expected in the western and north central parts of state, as well as in Burleigh and Cass Counties, while some counties in the northeast, southeast, and central parts of the state are expected to lose population (Figure ES1). 


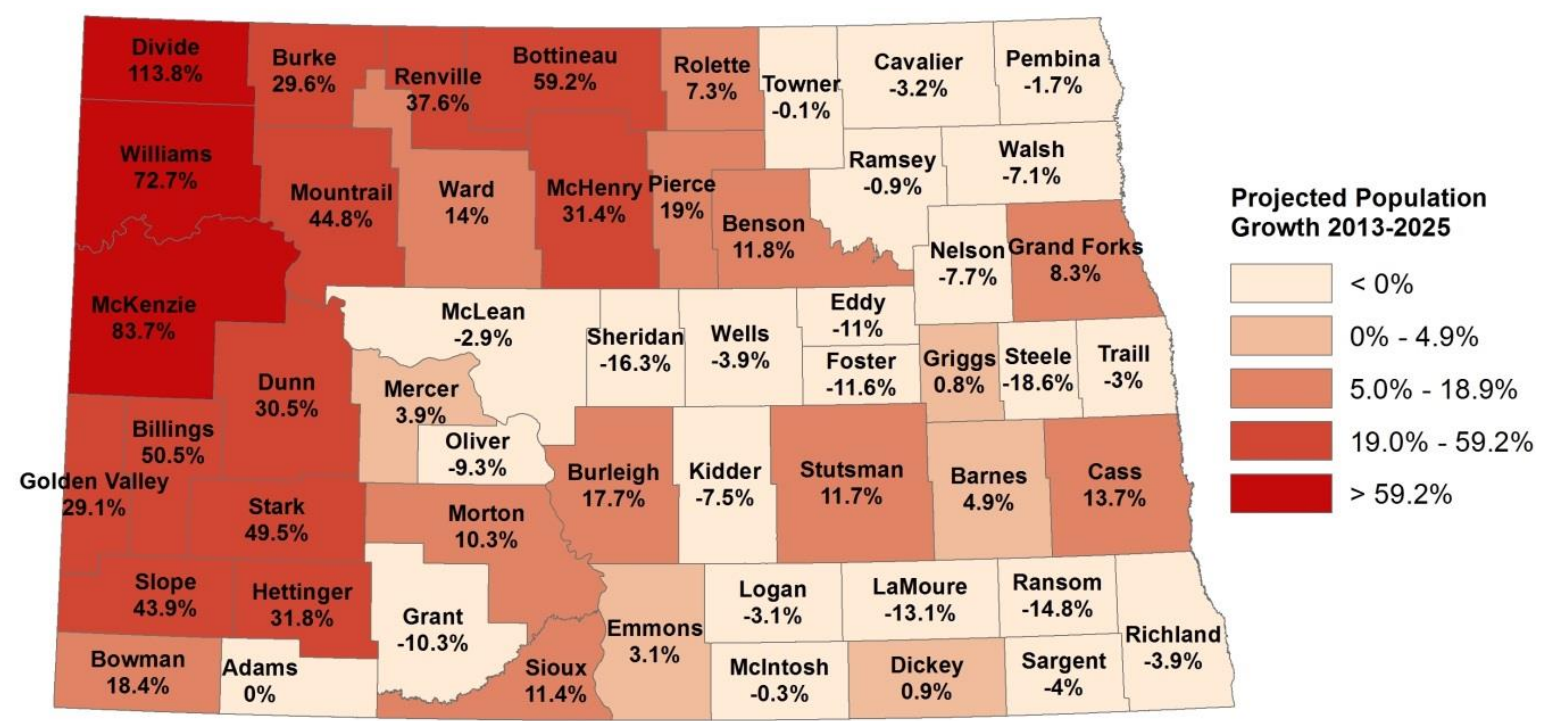

Figure ES1. Projected Population Growth from 2013 to 2025

The demographic characteristics of the population are also important determinants of the need for transit services. Older adults, people with disabilities, low-income individuals, and those without access to a vehicle are more likely to need transit services. Some of the low-population rural counties have a higher percentage of older adults or other groups that have a greater need for transit services. For example, in McIntosh, Sheridan, and Wells counties, $29 \%$ or more of the population is 65 or older; in Sioux, Rolette, and Benson counties, the population below the poverty line ranges from $35 \%$ to $43 \%$ and the population with a disability ranges from $44 \%$ to $49 \%$. With $8.4 \%$ of workers without access to a vehicle, Sioux county has the highest percentage of individuals without a vehicle to drive to work.

One trend expected to increase demand for transit services is the growth of the elderly population. Statewide, the population aged 65 or older is projected to increase 52\%, from 97,477 in 2010 to 148,060 in 2025. In 2010, 14.5\% of the state's population was aged 65 or older, and by 2025, it is expected that $17.9 \%$ will be 65 or older.

Total population, population aged 65 or older, population with a disability, population below the poverty line, and population of workers without access to a vehicle are important factors for determining mobility needs. Using these variables, a mobility need index, expressed with a 1-5 scale, was estimated to identify areas with the greatest needs for mobility services. The values calculated for each of North Dakota's counties are presented in Figure ES2. The results are fairly intuitive, as the more highly populated counties have the highest values. Some lower-population counties rank higher because of high concentrations of transportation-disadvantaged populations. 


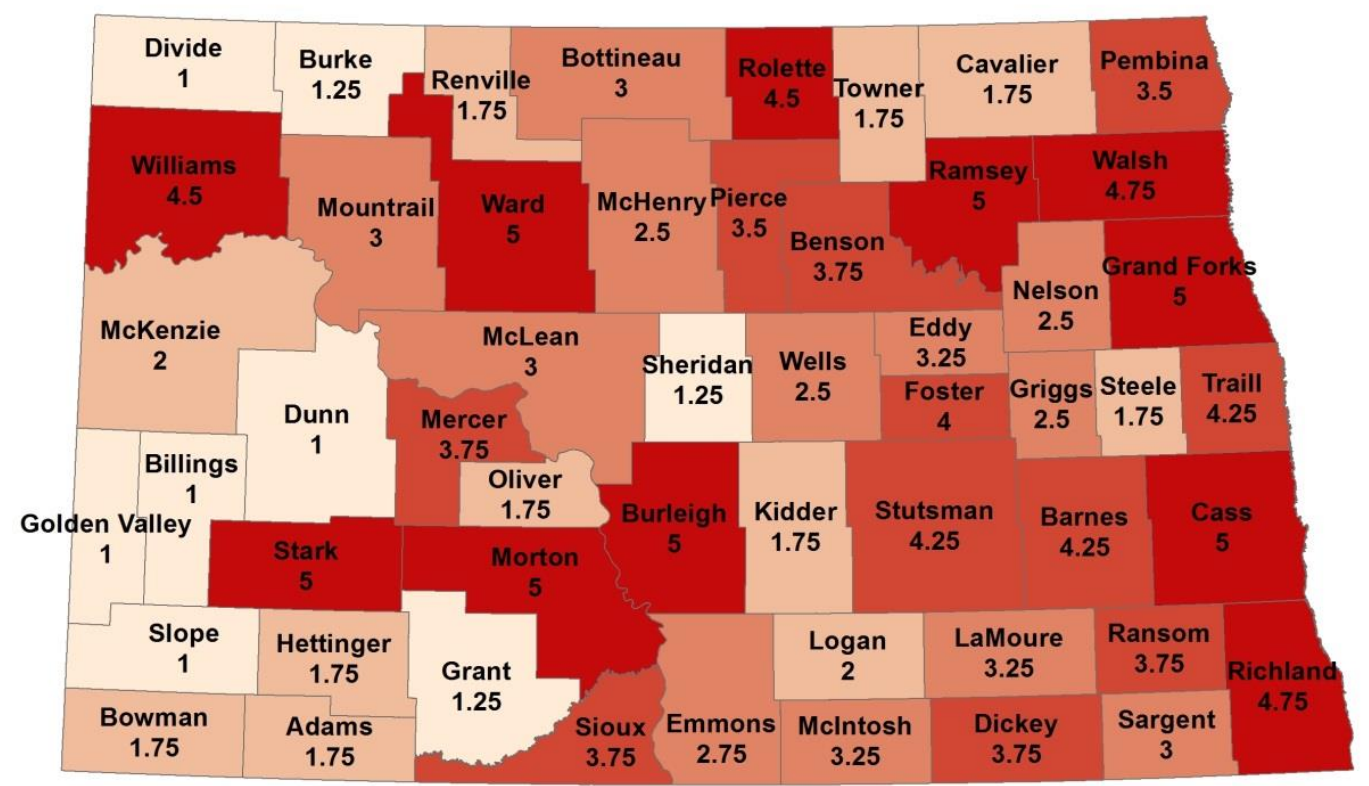

Figure ES2. Mobility Needs Index Map, County Level

\section{Mobility Gaps and Transit Needs}

\section{Transit Agency Needs}

Two surveys were conducted to gather information about existing transit services, how well those services are meeting the needs of the state's residents, and the issues and challenges facing transit providers across the state. The first was a survey of all transit agencies in the state and the second was a survey of human service agencies. The transit agency survey collected information regarding needed facility upgrades, the capacity for transit agencies to meet service requests, need for new services, and staffing needs. The survey of human service agencies also collected information regarding the need for new services to meet the demands of their clients.

Survey results suggest a need for an expansion of service. Sixteen transit agencies said there are some types of transportation services needed by their service area residents that are not currently available. Nearly all of respondents from human service agencies that were surveyed said that there are types of transportation services needed by their clients that are not currently available. Respondents from both transit agencies and human service agencies most commonly mentioned a need for longer hours of service, weekend service, and an expansion of currently available services. Six transit agencies mentioned a need for new fixed-route service, including agencies serving Fargo, Grand Forks, Minot, Dickinson, Williston, and Sioux County. The greatest needs are for medical and work trips.

A major finding from the survey of transit agencies is the need to improve staffing. Most indicated that their staffing is inadequate for current or future needs. Many agencies mentioned difficulties in finding enough qualified staff. Transit agencies, especially those in the western part of the state, have to 
compete with the oil industry, which pays much higher wages, for qualified drivers. Respondents from eastern regions of the state also commented on staffing issues, such as many of their employees being at or near retirement age and difficulties in finding qualified bus operators. Some transit providers have recently increased wages in an effort to keep good drivers. Transit agencies statewide may need to continue increasing wages to attract and maintain a qualified staff that is of sufficient size. Such wage increases would increase operating costs.

Other issues facing transit agencies include the need to replace vehicles and upgrade facilities. A substantial percentage of vehicles statewide have surpassed their useful life and need to be replaced. Regarding facility upgrades, there is a significant need for improving vehicle storage facilities. A majority of transit agencies indicated a need to upgrade vehicle storage facilities, either now or within the next five years.

\section{Transit Gaps}

Many counties have service at least 3-5 days per week. However, some areas have service just once or twice a week, and this might not be considered an adequate level of service, as reflected in the comments received by transit providers and human service agencies. Many respondents mentioned a need for more frequent service in rural areas, especially for medical trips.

Cities with a population of 4,500 to 20,000 all have demand-response service at least five days per week, but weekend services and evening services are limited. The greatest need in these communities is for evening and weekend service.

Among cities with a population of more than 20,000, Fargo-West Fargo, Bismarck-Mandan, and Grand Forks have fixed-route service six days per week, and Minot has fixed-route service five days per week. In Minot, there is demand for expanding the fixed-route service, as reflected in the survey comments. Fixed-route service in Minot is currently limited, with no weekend or evening service. As the city continues to grow, it is anticipated that demand for expanding the service will grow as well. The cities of Williston and Dickinson do not have fixed-route service but may have the demand to support such service. These cities may need to begin planning for fixed-route service. Fixed-route service in BismarckMandan is also limited.

To identify gaps in service and estimate the need for additional transit services across the state, this study examined three performance measures: trips per capita, vehicle miles of service per capita, and vehicle hours per capita. Figures ES3 and ES4 show 2013 data for trips provided and vehicle miles per capita for different regions of the state. These figures are useful for identifying regions of the state that currently have higher levels of service and other areas in need of service improvements. 


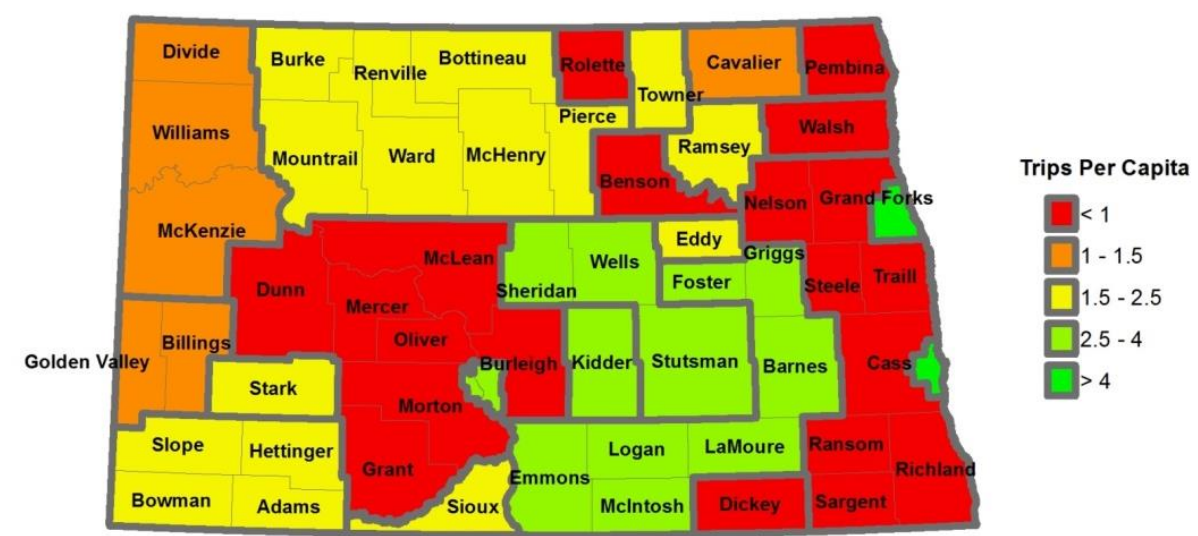

Figure ES3. Trips Provided Per Capita, by Region

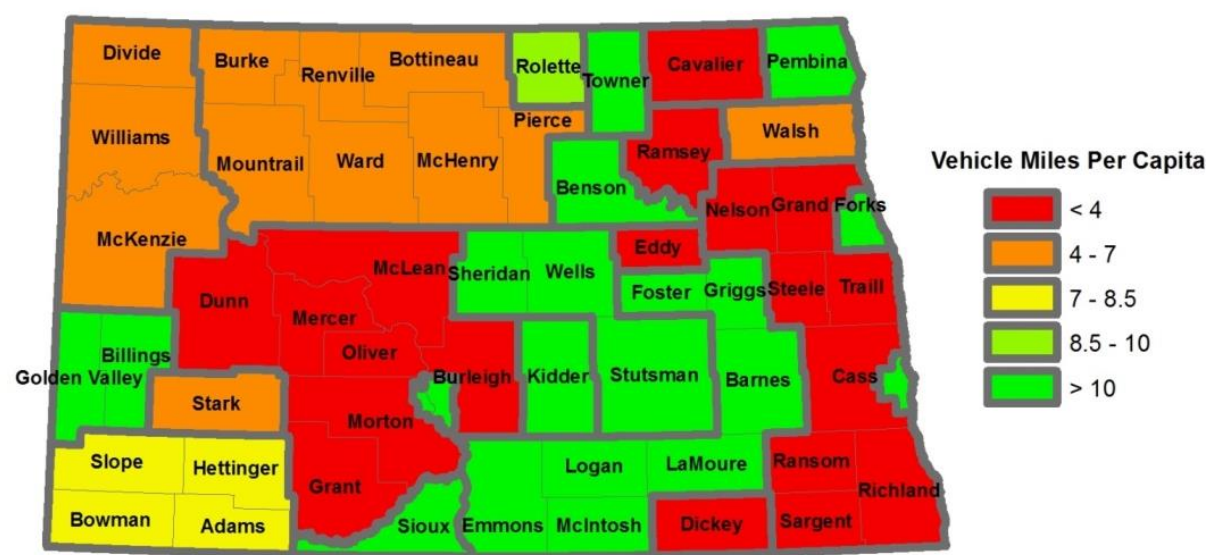

Figure ES4. Vehicle Miles of Service Per Capita, by Region

\section{Expanded Mobility Options}

The performance measures were compared to national averages for similar types of transit agencies which were used as benchmarks. Scenarios were estimated to determine increases in services needed for regions to meet the benchmark values. These scenarios also considered the impact of population growth and the growing senior population on future transit needs, and attention was given to improving hours and days of service in areas where service is currently most limited.

Four scenarios were analyzed to determine needed increases in service and the funding required to provide that service. Scenario 1 requires that each region meets at least one of the three benchmark values. Scenario 2 adds requirements that transit services increase at a rate equal to or greater than population growth, and it also considers the senior population and requires service increases in areas with limited days and hours of service. Scenario 3 includes the requirements of Scenario 2 and requires that each region must meet at least two of the three benchmarks. Scenario 4 includes the requirements of Scenario 3 and requires that each region must increase service by at least $10 \%$. Scenario 2 is the least costly scenario that meets the most basic transit needs. Justification can also be made for Scenarios 3 and 4 , as there are needs for additional services throughout the state. 
Table ES1 provides a summary of the increased operating and new vehicle expenses estimated in each of the scenarios. These estimates assume a $20 \%$ increase in per mile operating costs, needed to increase employee wages, and 2020 projected population, accounting for likely population growth within the next few years. These estimates are total increased expenses without consideration of funding source. In recent years, federal funds have accounted for $47 \%$ and $39 \%$ of rural and urban operating expenses, respectively, and $80 \%$ of capital expenses. However, state and local shares may need to increase to fund expanded transit services, given that federal transit funding may become stagnant.

Table ES1. Summary of Estimated Increase in Operating and Vehicle Expenses for Expanded Mobility Options, Assuming Projected 2020 Population

\begin{tabular}{|c|c|c|c|c|}
\hline & Scenario 1 & Scenario 2 & Scenario 3 & Scenario 4 \\
\hline \multicolumn{5}{|l|}{ Rural Transit } \\
\hline Annual operating expense & $\$ 2,836,425$ & $\$ 4,026,537$ & $\$ 5,657,762$ & $\$ 5,957,448$ \\
\hline \% increase over 2012 & $30 \%$ & $42 \%$ & $60 \%$ & $63 \%$ \\
\hline Vehicle expense (one-time cost) & $\$ 1,800,000$ & $\$ 2,550,000$ & $\$ 3,600,000$ & $\$ 3,800,000$ \\
\hline \multicolumn{5}{|l|}{ Urban Fixed-Route Transit } \\
\hline Annual operating expense & $\$ 2,173,276$ & $\$ 2,622,757$ & $\$ 3,244,377$ & $\$ 3,276,157$ \\
\hline \% increase over 2012 & $7 \%$ & $9 \%$ & $11 \%$ & $11 \%$ \\
\hline Vehicle expense (one-time cost) & $\$ 6,750,000$ & $\$ 8,100,000$ & $\$ 9,450,000$ & $\$ 9,450,000$ \\
\hline \multicolumn{5}{|l|}{ Urban Demand-Response Transit } \\
\hline Annual operating expense & $\$ 0$ & $\$ 345,648$ & $\$ 345,648$ & $\$ 382,239$ \\
\hline \% increase over 2012 & $0 \%$ & $2 \%$ & $2 \%$ & $3 \%$ \\
\hline Vehicle expense (one-time cost) & $\$ 0$ & $\$ 260,000$ & $\$ 260,000$ & $\$ 260,000$ \\
\hline \multicolumn{5}{|l|}{ Total } \\
\hline Annual operating expense & $\$ 5,009,701$ & $\$ 6,994,942$ & $\$ 9,247,787$ & $\$ 9,615,844$ \\
\hline \% increase over 2012 & $9 \%$ & $13 \%$ & $17 \%$ & $18 \%$ \\
\hline Vehicle expense (one-time cost) & $\$ 8,550,000$ & $\$ 10,910,000$ & $\$ 13,310,000$ & $\$ 13,510,000$ \\
\hline
\end{tabular}

The estimated vehicle expenses are one-time costs needed to increase fleet sizes across the state to allow for improved service levels. However, these vehicles will need to be replaced periodically, increasing annual capital expenditures. In addition, there currently are a significant number of vehicles in the state that have surpassed their useful life and are in need of replacement.

Table ES2 provides an estimate of the number of vehicles that will need to be replaced annually, on average, and the estimated cost of replacement. The table considers the current fleet, additional vehicles required under Scenario 2, assuming 2020 population, and the combined total. These are costs 
to be incurred in addition to the annual operating cost increases and new vehicle costs summarized in the previous table. All expenses are expressed in 2014 dollars.

Table ES2. Estimated Long-Term Annual Vehicle Replacement Costs

\begin{tabular}{lccc}
\hline & $\begin{array}{c}\text { Number } \\
\text { Replaced } \\
\text { Annually }\end{array}$ & $\begin{array}{c}\text { Average } \\
\text { Annual Cost }\end{array}$ & $\begin{array}{c}\text { Non-Federal } \\
\text { Share (20\%)* }\end{array}$ \\
\hline Current Fleet & 51 & $\$ 3,933,248$ & $\$ 786,650$ \\
Additional Vehicles & 11 & $\$ 1,022,085$ & $\$ 204,417$ \\
Total & 62 & $\$ 4,955,332$ & $\$ 991,066$ \\
\hline
\end{tabular}

*Assumes current $80 \%$ federal share continues. However, state and local shares may need to increase to fund vehicle purchases, given that federal transit funding may become stagnant.

Lastly, there are also significant needs for facility improvements across the state. This study does not provide a cost estimate of needed statewide facility upgrades, and prioritizing these projects is beyond the scope of this study. 


\section{TABLE OF CONTENTS}

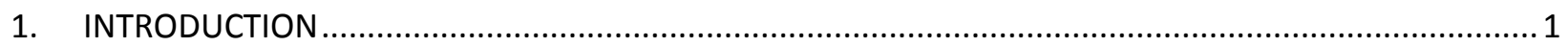

2. POPULATION GROWTH AND DEMOGRAPHIC PROFILES .......................................................... 3

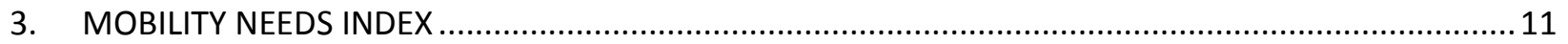

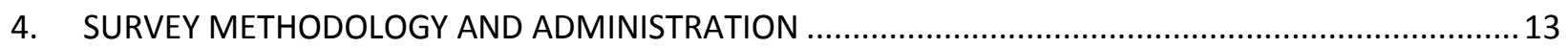

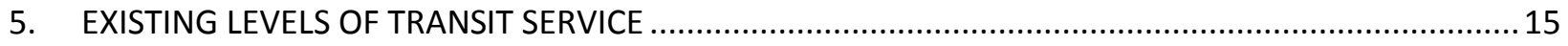

5.1 Data from the National Transit Database ….......................................................................... 15

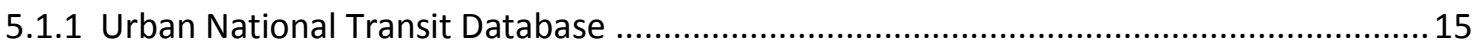

5.1.2 Rural National Transit Database .............................................................................. 18

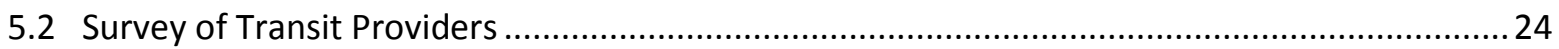

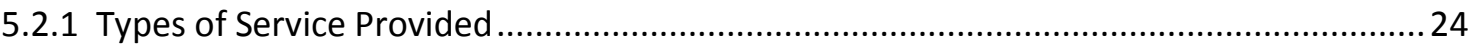

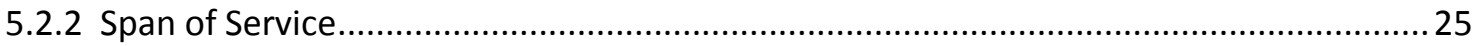

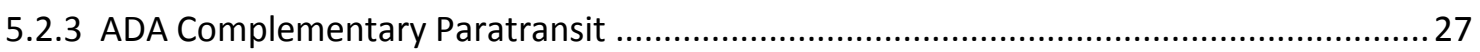

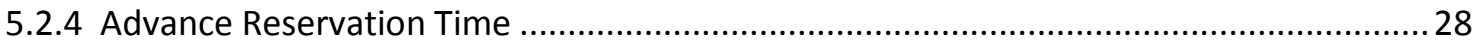

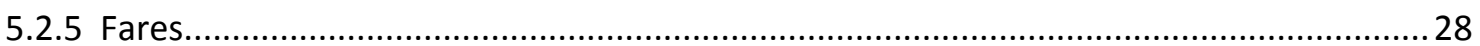

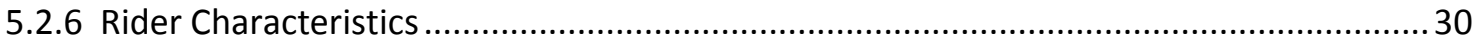

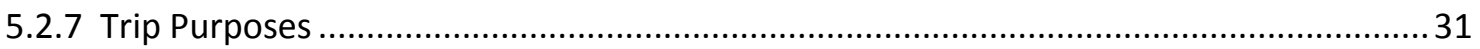

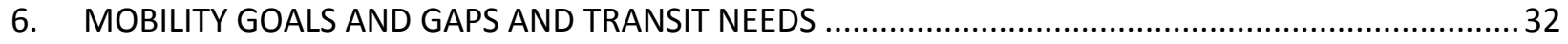

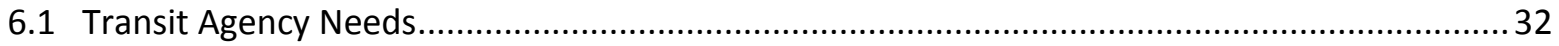

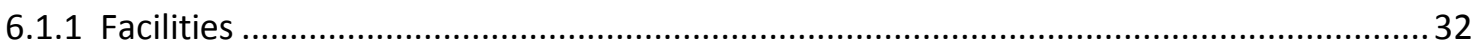

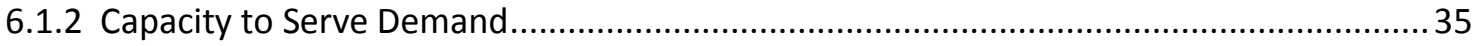

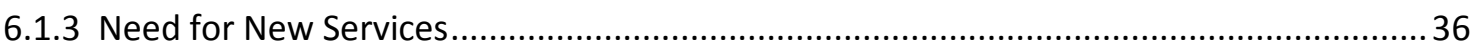

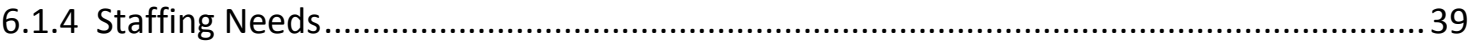

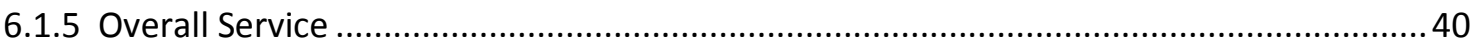

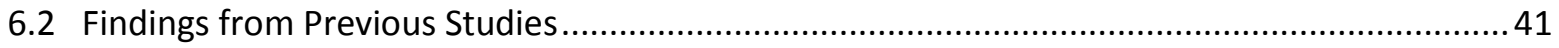

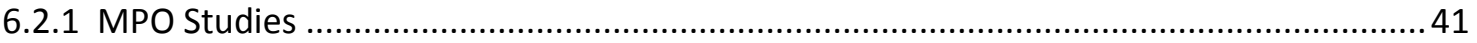

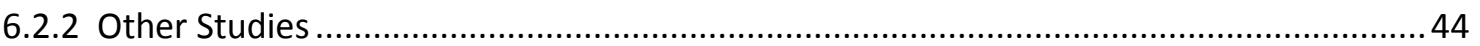

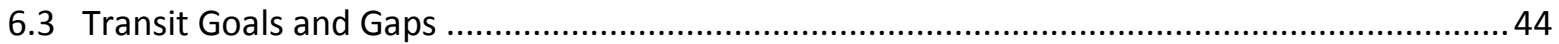

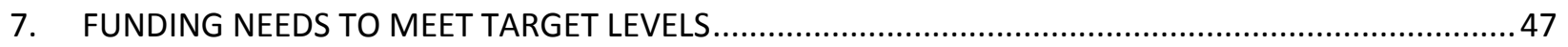

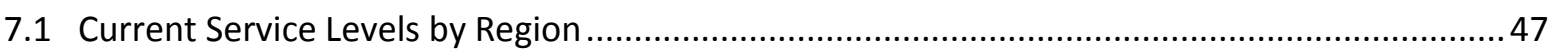

7.2 Estimated Increases in Services to Meet Target Levels .......................................................... 51

7.3 Estimated Operating and Vehicles Expenses for Expanded Mobility Options ..........................56

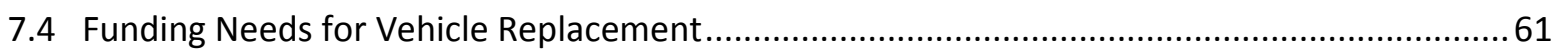

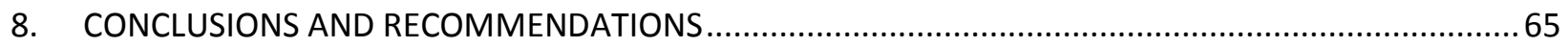

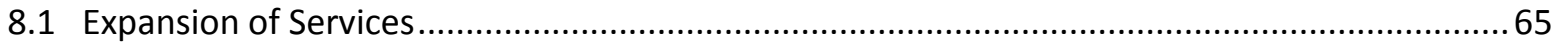




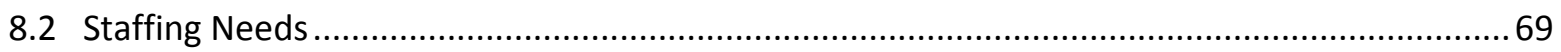

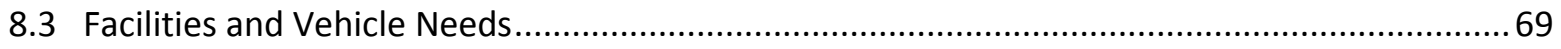

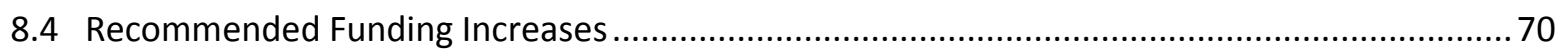

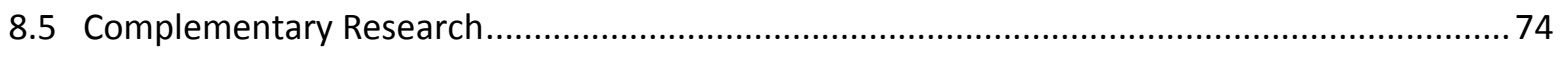

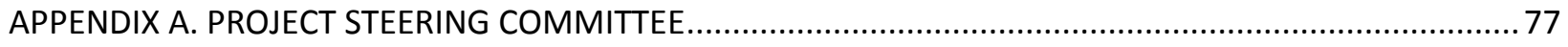

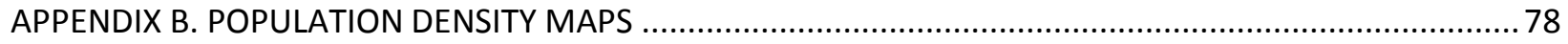

APPENDIX C. PERCENTAGE OF POPULATION CONSISTING OF TRANSPORTATION-DISADVANTAGED

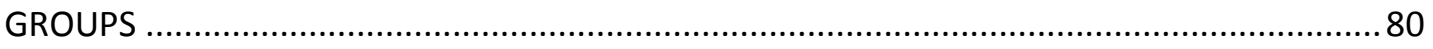

APPENDIX D. RESULTS FROM SURVEY OF HUMAN SERVICE AGENCIES …......................................... 82

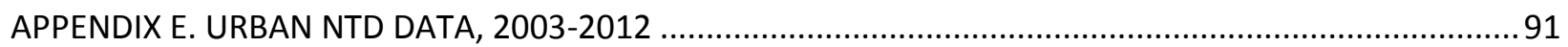

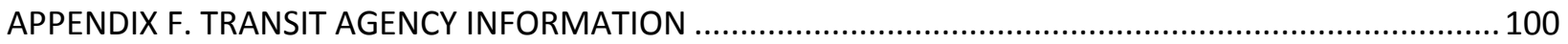

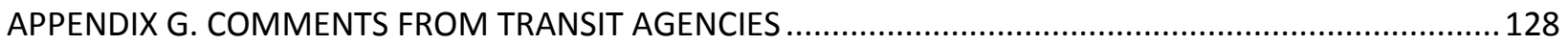




\section{LIST OF FIGURES}

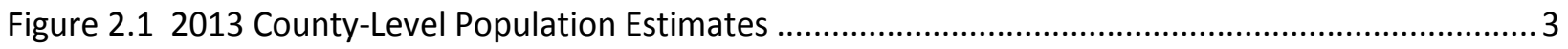

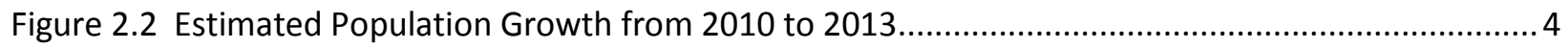

Figure 2.3 Projected Population Growth from 2013 to 2025 ................................................................... 4

Figure 2.4 Population Aged 65 or Older, 2008-2012 ACS 5-Year Estimates ........................................... 5

Figure 2.5 Population below the Poverty Level, 2008-2012 ACS 5-Year Estimates.................................. 5

Figure 2.6 Population with a Disability, 2008-2012 ACS 5-Year Estimates ............................................. 5

Figure 2.7 Workers without Access to a Vehicle, 2008-2012 ACS 5-Year Estimates ................................ 6

Figure 2.8 Projected Growth of Population Aged 65 or Older, 2010 - 2025......................................... 7

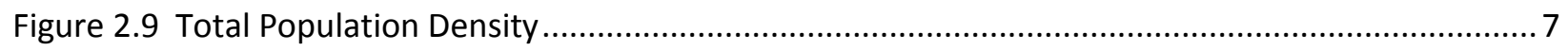

Figure 2.10 Population Aged 65 or Older per Square Mile .................................................................

Figure 2.11 Population with Disability per Square Mile .................................................................... 8

Figure 2.12 Population below Poverty Line per Square Mile ............................................................

Figure 2.13 Workers without Access to a Vehicle per Square Mile ........................................................ 9

Figure 3.1 Mobility Needs Index Map, County Level ......................................................................... 12

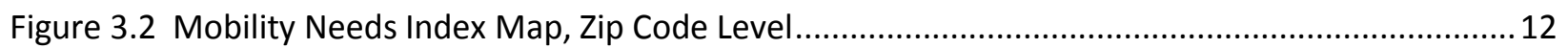

Figure 4.1 Responses to Survey of Human Service Agencies by County ................................................ 14

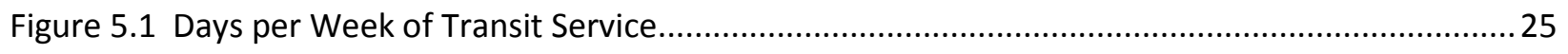

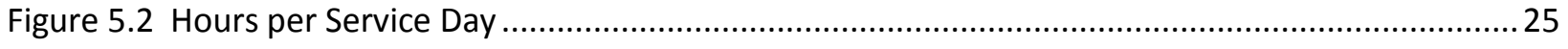

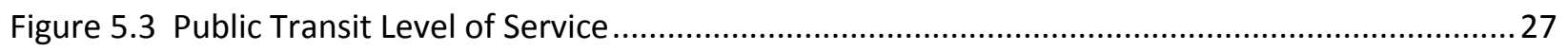

Figure 6.1 Adequacy of Facilities for Needs ....................................................................................... 33

Figure 6.2 Survey results: Are there any types of transportation services needed by your clients or service area residents that are not currently available? ......................................................................... 36

Figure 6.3 Types of Services Needed, Responses from Transit Agencies .............................................. 37

Figure 6.4 Need for More Service for Specific Types of Trips, Responses from Transit Agencies..............38

Figure 6.5 Need for More Service for Specific Types of Trips, Responses from Human Service

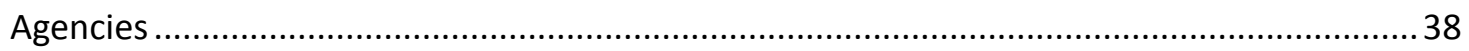

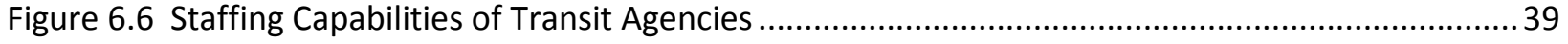

Figure 6.7 How Well the Needs of Residents are Being Met ............................................................... 40

Figure 6.8 Responses from Human Service Agencies on How Well Transportation Needs are Being

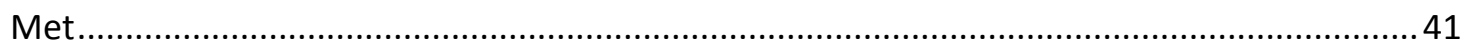

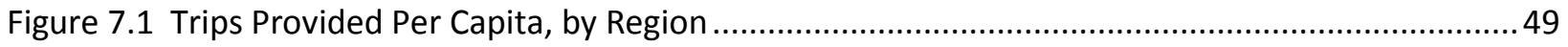

Figure 7.2 Vehicle Miles of Service Per Capita, by Region ................................................................... 49

Figure 7.3 Vehicle Hours of Service Per Capita, by Region ...............................................................5

Figure 7.4 Vehicles Per 1,000 Population, by Region............................................................................50 


\section{LIST OF TABLES}

Table 2.1 City-Level Population and Demographic Data, 2008-2012 Estimates ................................10

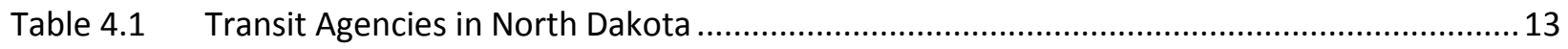

Table 5.1 Urban Fixed-Route Transit Data, 2012 ............................................................................ 16

Table 5.2 Urban Demand-Response Transit Data, 2012 .............................................................. 17

Table 5.3 Urban Transit Funding Data, by Source, 2012 .................................................................. 18

Table 5.4 Rural Transit Agencies: Statewide Data........................................................................ 19

Table 5.5 Rural Transit Agencies: Agency-Level Operating Statistics, 2009-2013..............................20

Table 5.6 Rural Transit Agencies: Agency-Level Fleet Statistics and Performance Measures,

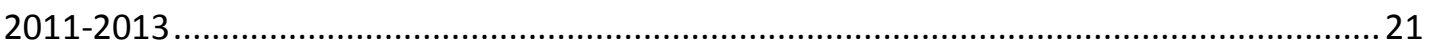

Table 5.7 Rural Transit Agencies: Agency-Level Operating Expenses and Performance Measures, .........

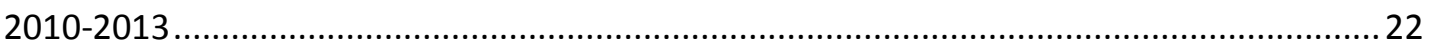

Table 5.8 Rural Transit Agencies: Trips Per Vehicle Mile and Trips Per Vehicle Hour, 2009-2013 ....... 23

Table 5.9 What type of transportation services does your organization provide

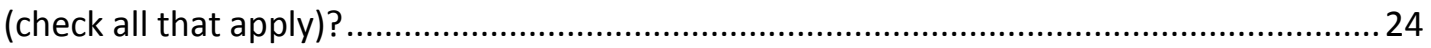

Table 5.10 Do you provide the following types of service (check all that apply)? ................................24

Table 5.11 Framework for Measuring Service Span Level of Service ...................................................26

Table 5.12 What is the minimum advance reservation time for your agency operating demand-

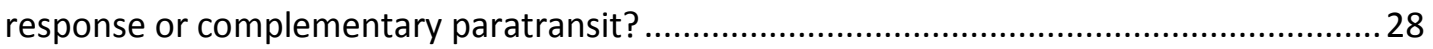

Table 5.13 One-Way Fares Charged by Demand-Response Transit Providers.....................................29

Table 5.14 Fares Charged by Fixed-Route Transit Providers...............................................................29

Table 5.15 Percentage of Riders that are Older Adults, People with Disabilities, or Youth ...................30

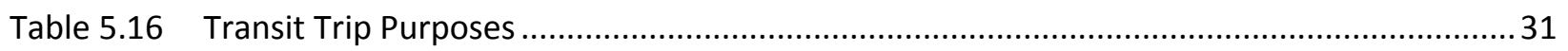

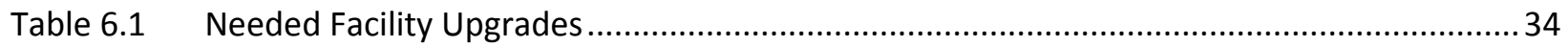

Table 6.2 Percentage of Demand-Response Transit Trip Requests Turned Down Because of Lack

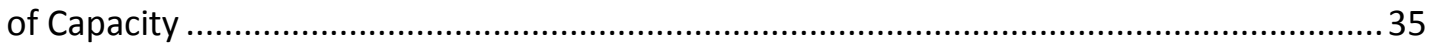

Table 6.3 Mobility Goals for North Dakota Developed by Mielke et al. (2005) .................................. 45

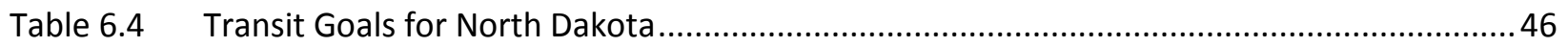

Table 7.1 Regional Transit Service Areas and Population Data.........................................................47

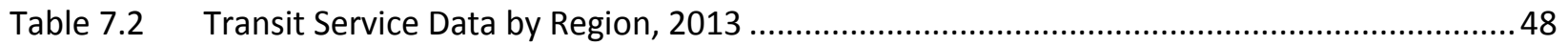

Table 7.3 Rural and Small Urban Transit Service Benchmarks: National Averages ..............................52

Table 7.4 Increase in Vehicle Miles Needed in each Scenario, Given Current Population ...................54

Table 7.5 Increase in Vehicle Miles Needed in Each Scenario, Given Projected Population for

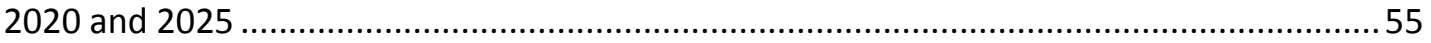

Table 7.6 Estimated Increases in Operating and Vehicle Expenses for Expanded Mobility

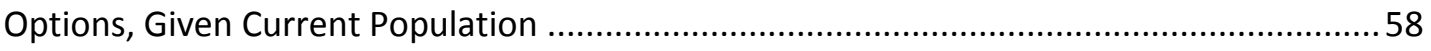

Table 7.7 Estimated Increases in Operating and Vehicle Expenses for Expanded Mobility

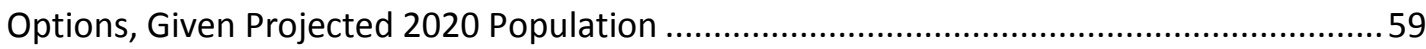

Table 7.8 Estimated Increases in Operating and Vehicle Expenses for Expanded Mobility

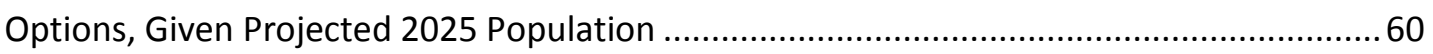

Table 7.9 Sources of North Dakota Transit Funding, 2009-2012 .....................................................61 


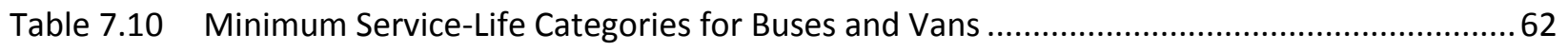

Table 7.11 Estimated Current Vehicle Replacement Needs.................................................................63

Table 7.12 Long-Term Annual Average Vehicle Replacement Costs....................................................64

Table 8.1 Summary of Estimated Increase in Expenses for Expanded Mobility Options.......................71

Table 8.2 Rural Transit: Estimated Increase in Operating and Vehicle Expenses by Funding Source for 2020 Projected Population Scenarios, Assuming Current Funding Shares* ...................... 72

Table 8.3 Urban Fixed-Route Transit: Estimated Increase in Operating and Vehicle Expenses by Funding Source for 2020 Projected Population Scenarios, Assuming Current Funding Shares*

Table 8.4 Urban Demand-Response Transit: Estimated Increase in Operating and Vehicle Expenses by Funding Source for 2020 Projected Population Scenarios, Assuming Current Funding Shares*

Table 8.5 Total Rural and Urban Transit: Estimated Increase in Operating and Vehicle Expenses by Funding Source for 2020 Projected Population Scenarios, Assuming Current Funding Shares* .73

Table 8.6 Estimated Long-Term Annual Vehicle Replacement Costs................................................. 74

Table E.1 Urban Transit Agencies: Unlinked Passenger Trips ...........................................................91

Table E.2 Urban Transit Agencies: Vehicle Revenue Miles ............................................................. 91

Table E.3 Urban Transit Agencies: Vehicle Revenue Hours ................................................................. 92

Table E.4 Urban Transit Agencies: Passenger Miles Traveled ............................................................92

Table E.5 Urban Transit Agencies: Vehicles Available for Maximum Service .................................... 93

Table E.6 Urban Transit Agencies: Average Fleet Age.................................................................. 93

Table E.7 Urban Transit Agencies: Total Operating Expenses........................................................... 94

Table E.8 Urban Transit Agencies: Unlinked Passenger Trips per Vehicle Revenue Mile .....................94

Table E.9 Urban Transit Agencies: Unlinked Passenger Trips per Vehicle Revenue Hour .................... 95

Table E.10 Urban Transit Agencies: Unlinked Passenger Trips per Vehicle ...........................................95

Table E.11 Urban Transit Agencies: Vehicle Revenue Miles per Vehicle ..............................................96

Table E.12 Urban Transit Agencies: Vehicle Revenue Hours per Vehicle ..............................................96

Table E.13 Urban Transit Agency: Operating Cost per Trip................................................................97

Table E.14 Urban Transit Agency: Operating Cost per Vehicle Revenue Mile ......................................97

Table E.15 Urban Transit Agencies: Farebox Recovery Ratio......................................................... 98

Table E.16 Urban Transit Agencies: Operating Funds by Source ...................................................... 98

Table E.17 Urban Transit Agencies: Capital Funds by Source ...........................................................99

Table G.1 Challenges to Providing New Services ....................................................................... 128

Table G.2 Staffing Needs........................................................................................................ 129

Table G.3 Comments on How Well Transportation Needs of Service Area Residents are

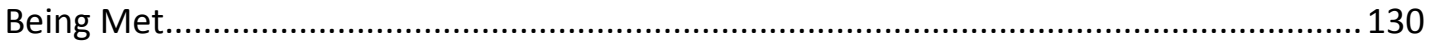

Table G.4 Additional Comments from Transit Agencies ............................................................ 131 


\section{INTRODUCTION}

The state of North Dakota recognizes the need for a transportation system that allows for optimum personal mobility. This need was addressed in one of the goals originally established in the North Dakota Department of Transportation's (NDDOT) TransAction Statewide Strategic Transportation Plan in 2002. It was reiterated when TransAction was updated in 2007 and 2012. In the latest plan, TransAction III, Initiative 3 is to improve the performance of the transportation system - both infrastructure and services. Included among the strategies for this initiative are monitoring key trends affecting personal mobility, promoting personal mobility, and developing personal mobility performance measures. NDDOT previously contracted with the Small Urban and Rural Transit (SURTC) to prepare a report, "Personal Mobility in North Dakota: Trends, Gaps, and Recommended Enhancements," in 2005. The current study addresses the issues identified in TransAction III and updates information developed in previous studies.

This study provides North Dakota policy makers with a guide to future development of personal mobility options and identifies gaps that either exist now in mobility services or are likely to exist in the near future as the result of service modifications or changing demographics and population growth. The scope of the mobility study includes local and regional passenger transportation.

Results can be used to identify programmatic and funding needs related to personal mobility, determine funding priorities for the use of state funds and federal funds under state control, and provide guidance to city and county governments for addressing personal mobility needs. Further, the data collected can be used by local and regional agencies to plan for new or revised local services. Finally, the shrinking transit trust fund could mean reduced federal funding for North Dakota transit systems, resulting in either reduced services or an increased need for state and local funding. This study illustrates how this uncertainty regarding federal funding could impact state funding needs.

The objective of this study is to determine the financial needs of the state transit providers. Specific objectives include the following:

1. Construct a demographic profile of the state of North Dakota

2. Develop a mobility needs index

3. Describe existing levels of transit service across the state

4. Identify base levels of required transit service and gaps in existing service

5. Develop recommendations for meeting mobility needs

6. Determine the level of funding needed to maintain the current level of service

7. Determine the level of funding needed to expand the existing level of service

A project steering committee was created, comprised of staff from the NDDOT and representatives from transit operators, metropolitan planning organizations, and a constituent group. The steering committee provided input regarding the scope of work and survey development, helped identify important issues, and reviewed drafts of the report. A list of the steering committee members is provided in Appendix A. 
This report is organized as follows. Section 2 provides county-level population growth and demographic data, as well as some zip-code-level data. These data were used to construct a mobility needs index, which is presented in Section 3. Two surveys were conducted to gather information about existing transit services, how well those services are meeting the needs of the state's residents, and the issues and challenges facing transit providers across the state. The first was a survey of all transit agencies in the state, and the second was a survey of human service agencies. The development of these surveys is described in Section 4. A description of existing levels of transit service across the state, based on survey responses from transit agencies and National Transit Database (NTD) data, is provided in Section 5, and Section 6 discusses transit agency needs and mobility goals and gaps. Target levels of transit service are identified, and the funding needed to reach those targets, including funds to cover increased operating expenses and vehicle purchases, are estimated in Section 7. Section 8 provides conclusions and recommendations and a summary of findings. 


\section{POPULATION GROWTH AND DEMOGRAPHIC PROFILES}

Population growth and demographic trends are impacting the needs for public transportation services across the state. Estimated statewide population for North Dakota climbed to 723,393 in 2013, an 8\% increase from the 2010 census. Previously, the statewide population grew 5\% from 2000 to 2010. Population is projected to increase to 841,820 by 2025 , a $16 \%$ increase from 2013 estimates (Center for Social Research 2012). Figure 2.1 shows county-level population estimates for 2013.

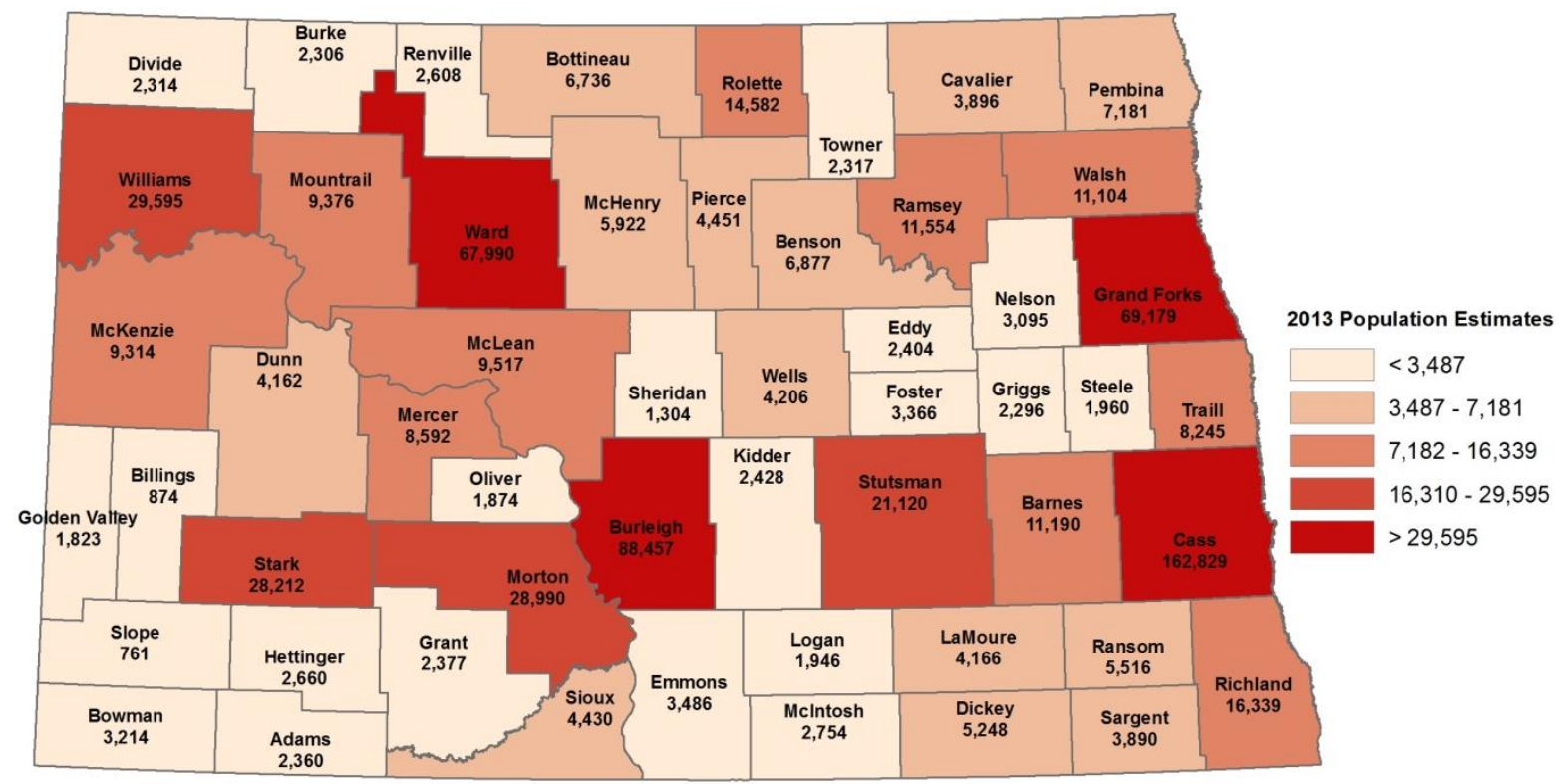

Figure 2.12013 County-Level Population Estimates

The greatest population growth in recent years occurred in the western part of the state, as shown in Figure 2.2. Population in McKenzie and Williams counties is estimated to have increased $46 \%$ and $32 \%$, respectively, from the 2010 census to 2013. There has also been significant growth in Cass and Burleigh counties, the most populous counties in the state.

Current population growth trends are expected to continue over the next decade. The Center for Social Research at North Dakota State University has made population projections through the year 2025.

Figure 2.3 shows projected population growth from 2013 to 2025. Significant growth is expected in the western and north central parts of state, as well as Burleigh and Cass Counties, while some counties in the northeast, southeast, and central parts of the state are expected to lose population. 


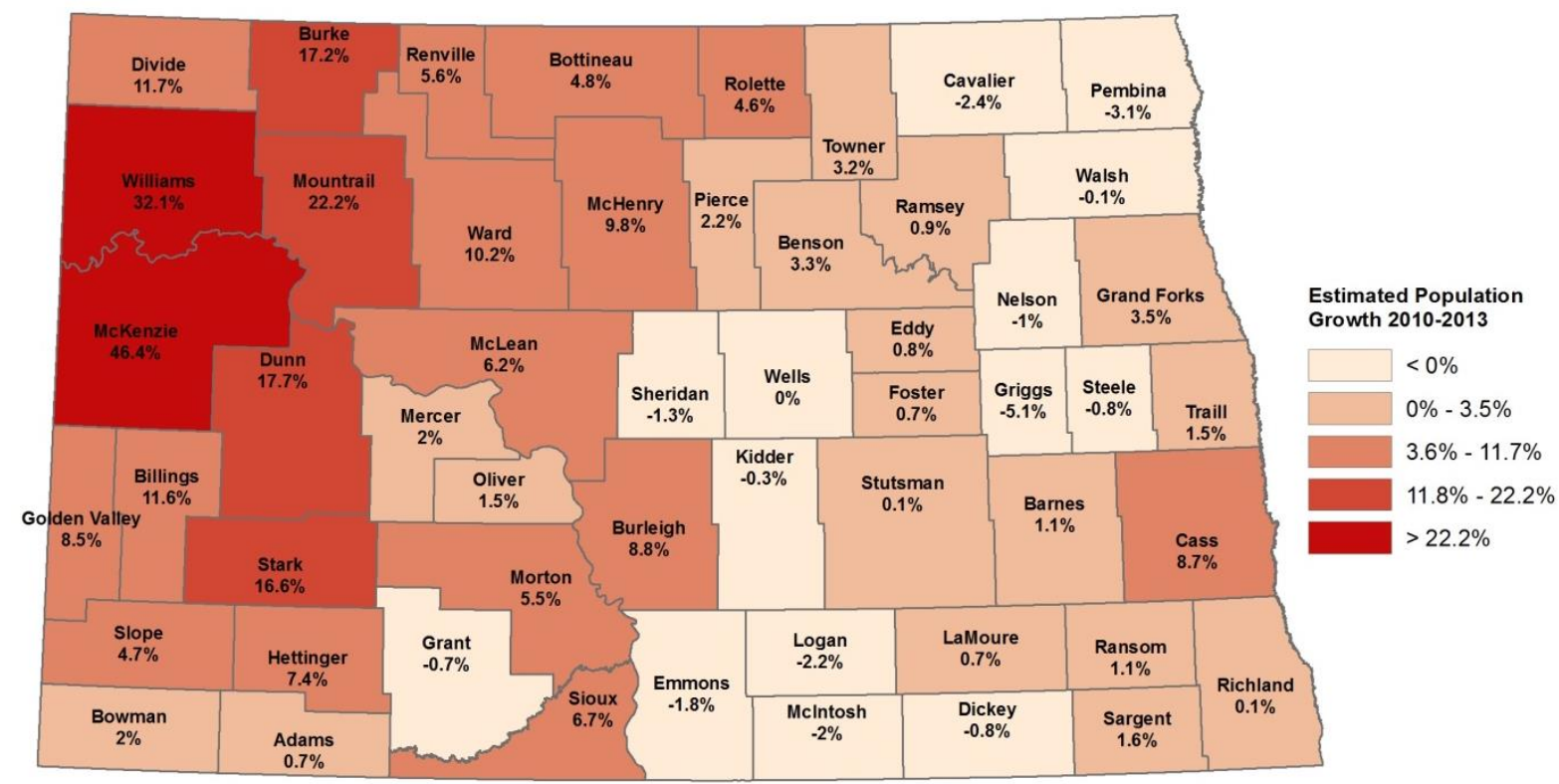

Figure 2.2 Estimated Population Growth from 2010 to 2013

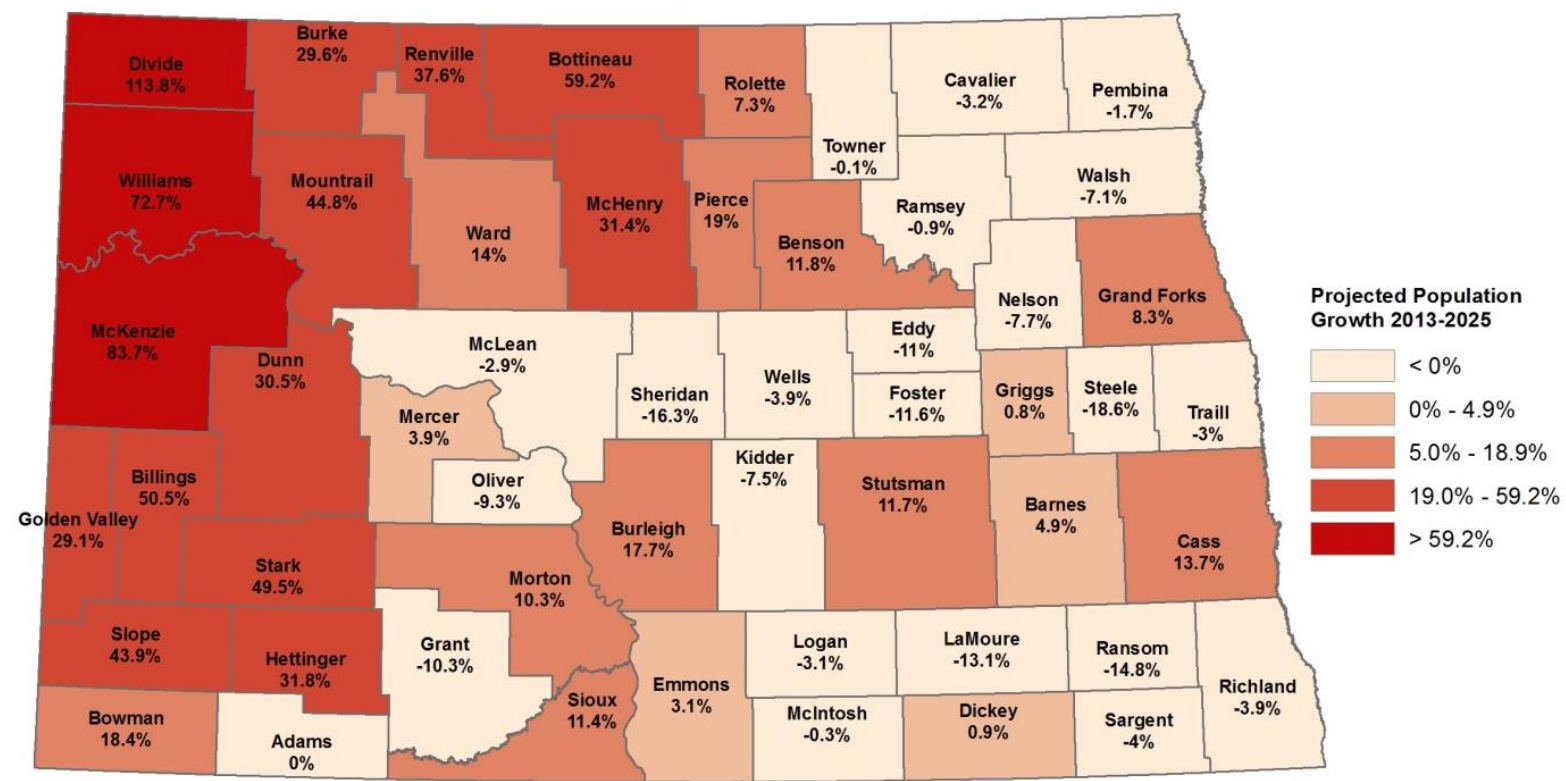

Figure 2.3 Projected Population Growth from 2013 to 2025

Need for transit services is impacted by both total population and the demographic characteristics of the population. Older adults, people with disabilities, low-income individuals, and those without access to a vehicle are more likely to need transit services.

Data from the American Community Survey (ACS) were used to develop demographic profiles and identify the population of these transportation-disadvantaged groups. Data were used from the 20082012 ACS five-year estimates. Figures 2.4-2.7 show the county-level population data for adults aged 65 or older, individuals living below the poverty line, people with disabilities, and workers without access to a vehicle. 


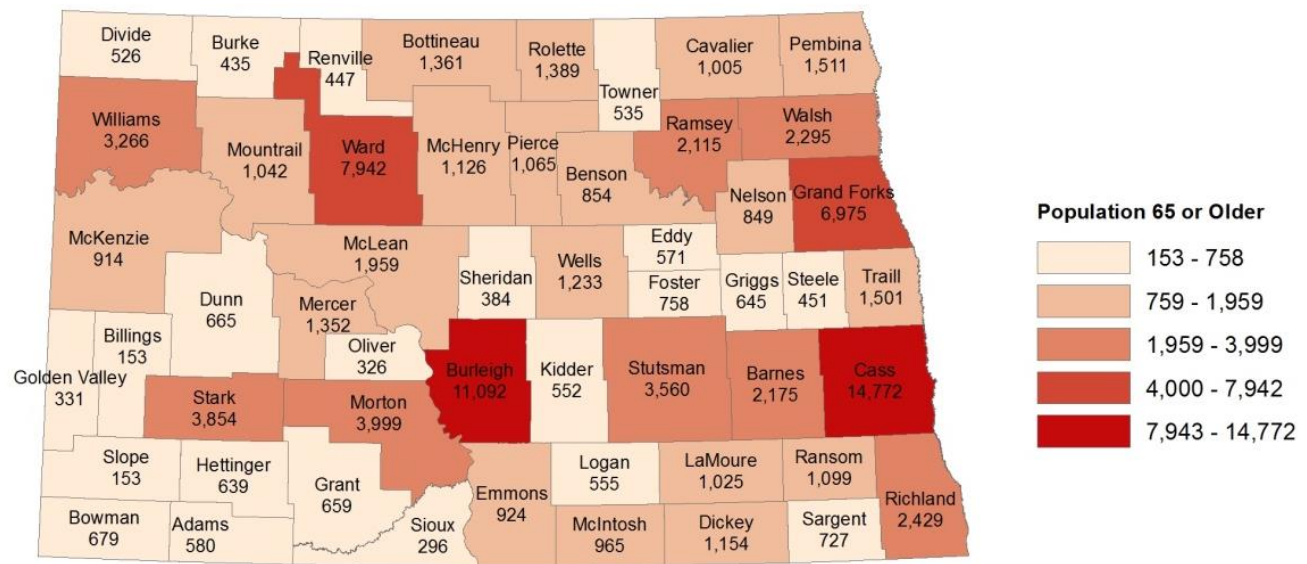

Figure 2.4 Population Aged 65 or Older, 2008-2012 ACS 5-Year Estimates

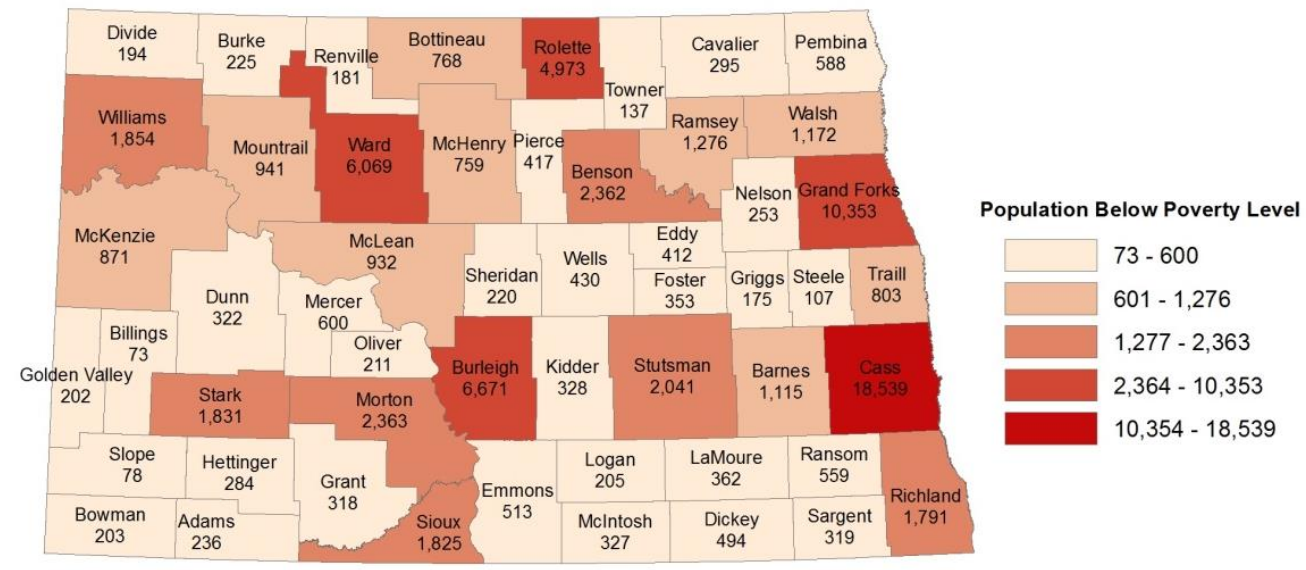

Figure 2.5 Population below the Poverty Level, 2008-2012 ACS 5-Year Estimates

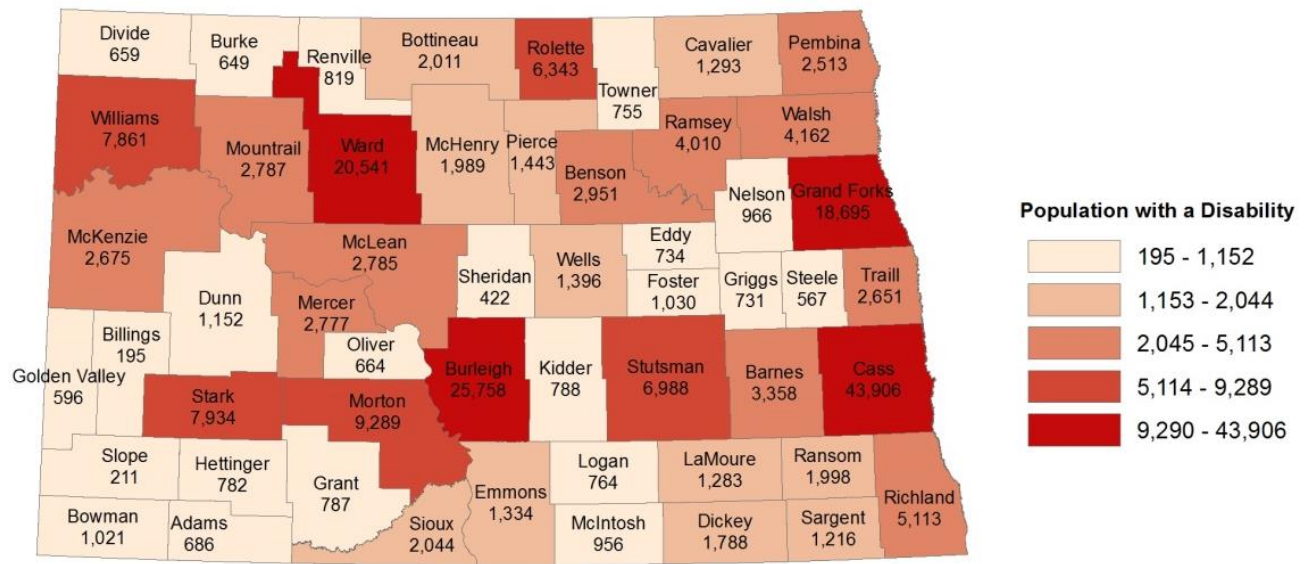

Figure 2.6 Population with a Disability, 2008-2012 ACS 5-Year Estimates 


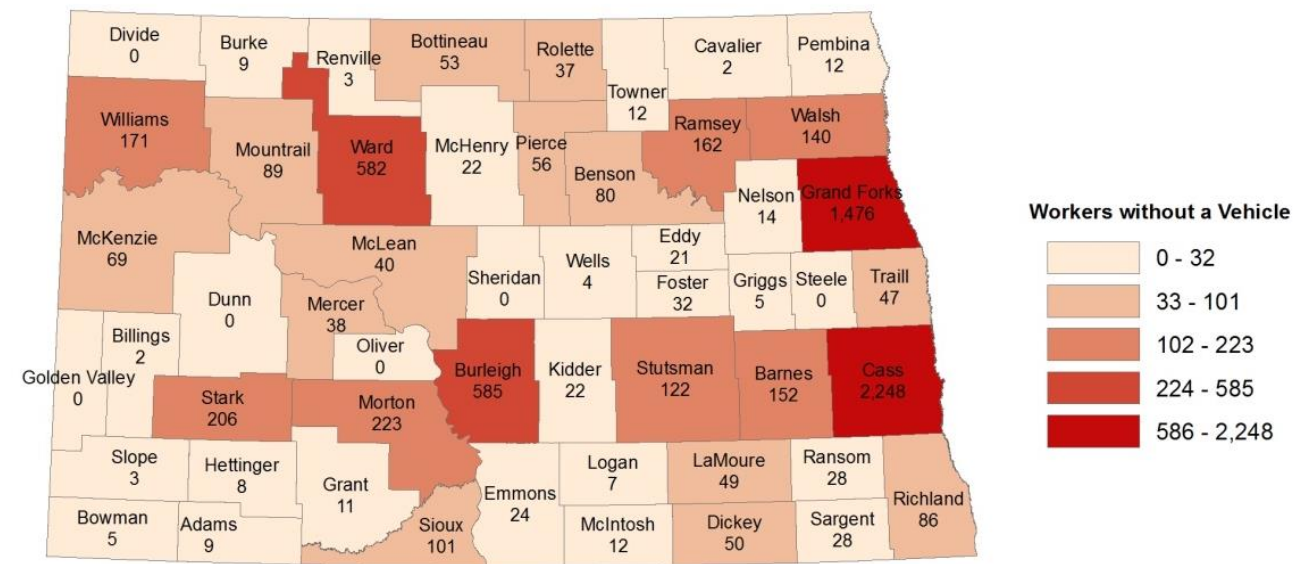

Figure 2.7 Workers without Access to a Vehicle, 2008-2012 ACS 5-Year Estimates

Additional maps showing population densities are presented in Appendix B. Appendix C shows the percentage of county population consisting of these transportation-disadvantaged groups. In some lowpopulation rural counties there are higher percentages of older adults or other groups that have a greater need for transit services. For example, in McIntosh, Sheridan, and Wells counties, $29 \%$ or more of the population is 65 or older. In Sioux, Rolette, and Benson counties, the population below the poverty line ranges from $35 \%$ to $43 \%$ and the population with a disability ranges from $44 \%$ to $49 \%$. With $8.4 \%$ of workers without access to a vehicle, Sioux county has the highest percentage of individuals without a vehicle to drive to work.

One trend expected to increase demand for transit services is the growth of the elderly population. Figure 2.8 shows the projected increase in the population 65 or older from 2010 to 2025. Statewide, the population for this group is projected to increase 52\% over this period, from 97,477 in 2010 to 148,060 in 2025. Growth in the elderly population is outpacing total population growth. In $2010,14.5 \%$ of the state's population was 65 or older, and by 2025 , it is expected that $17.9 \%$ will be 65 or older. The population 65 or older is projected to more than double in the northwest counties of Divide, Williams, and McKenzie, while significant increases are also projected elsewhere throughout the state, including a $94 \%$ increase in Cass County, the state's most populous county.

Though counties in the western part of North Dakota are experiencing major population growth, the population densities will still be relatively low, making it difficult to provide conventional fixed-route or demand-response services. Likewise, some already sparsely settled counties are projected to lose population, presenting a challenge to offering cost-effective transit, especially since residents of these counties are more likely to be elderly, have disabilities, or live in low-income households that need transit. 


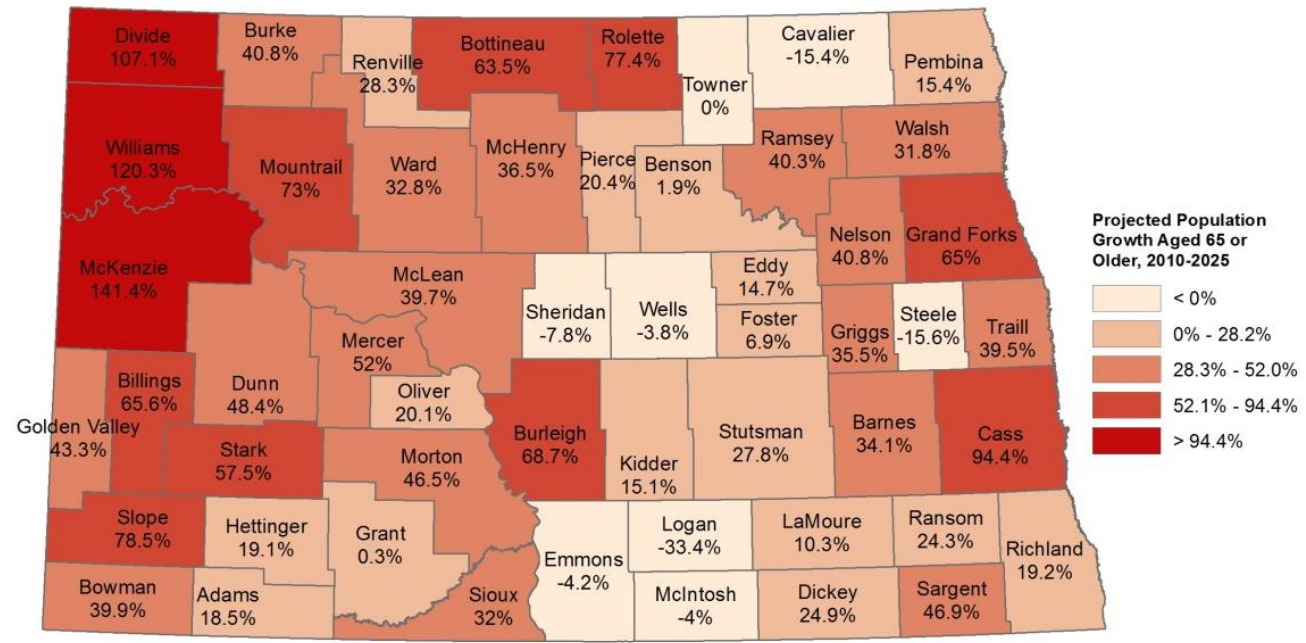

Figure 2.8 Projected Growth of Population Aged 65 or Older, 2010 - 2025

Examining data at a finer detail than the county level and analyzing population density data provides more information for identifying areas where the greatest needs for public transit services exist. Figures 2.9-2.13 show population density data represented at the zip code level. Figure 2.9 shows total population density, while Figures 2.10-2.13 show densities of different transportation-disadvantaged populations.

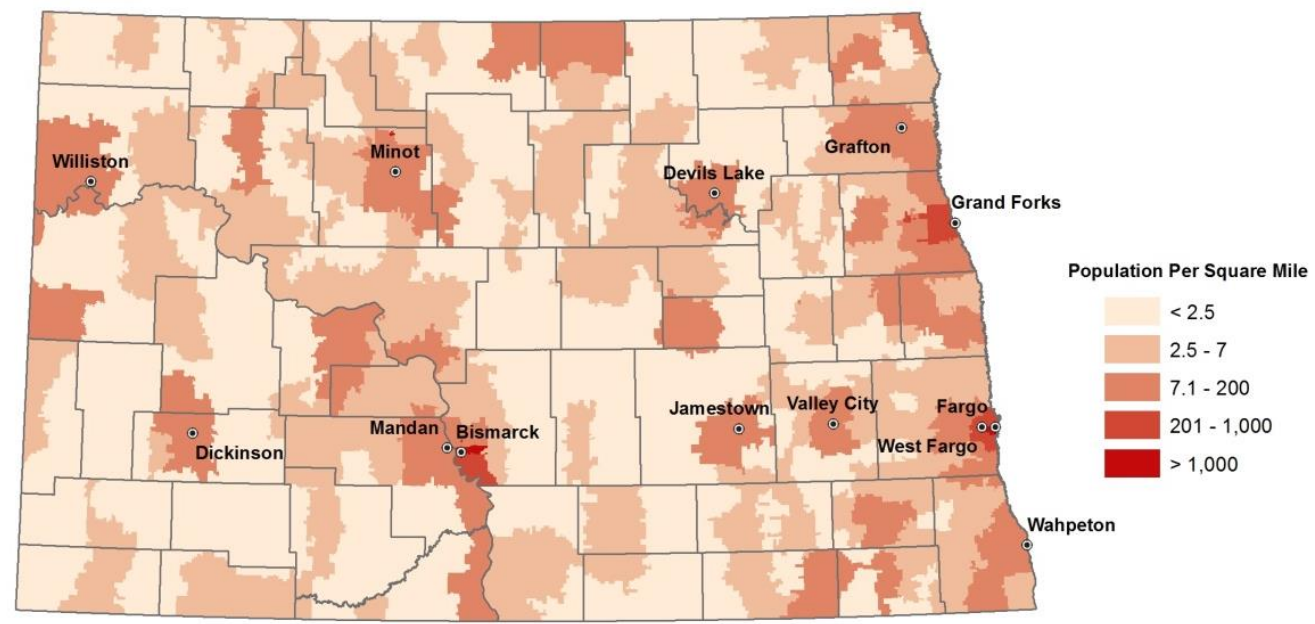

Figure 2.9 Total Population Density 


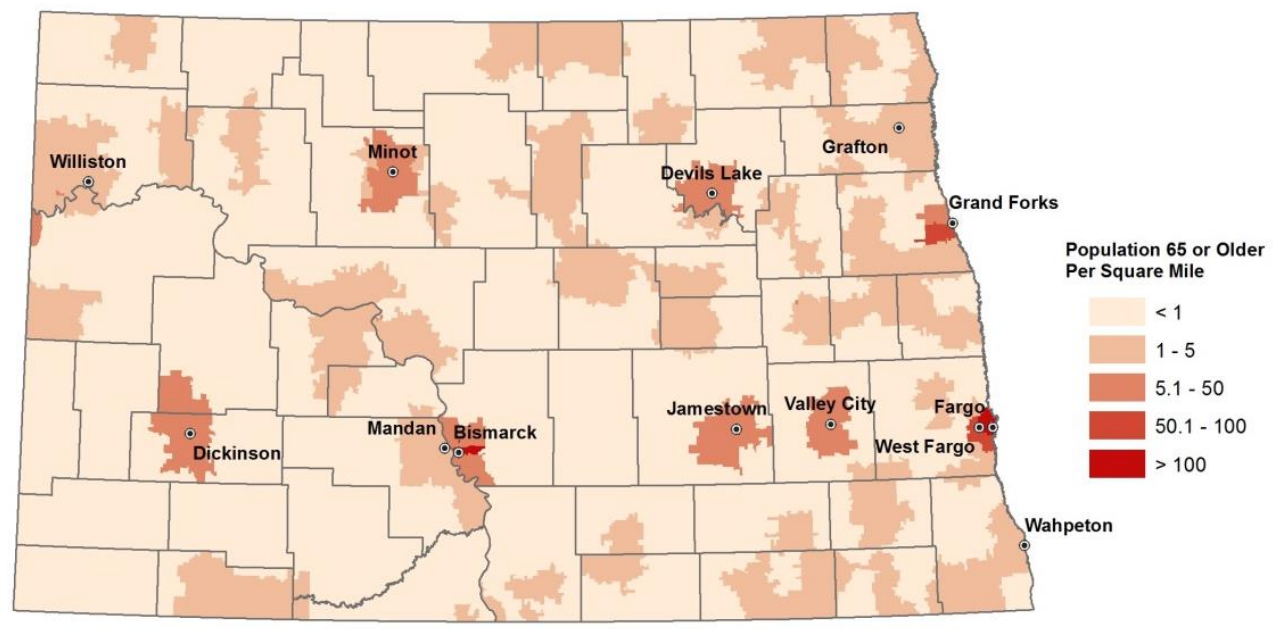

Figure 2.10 Population Aged 65 or Older per Square Mile

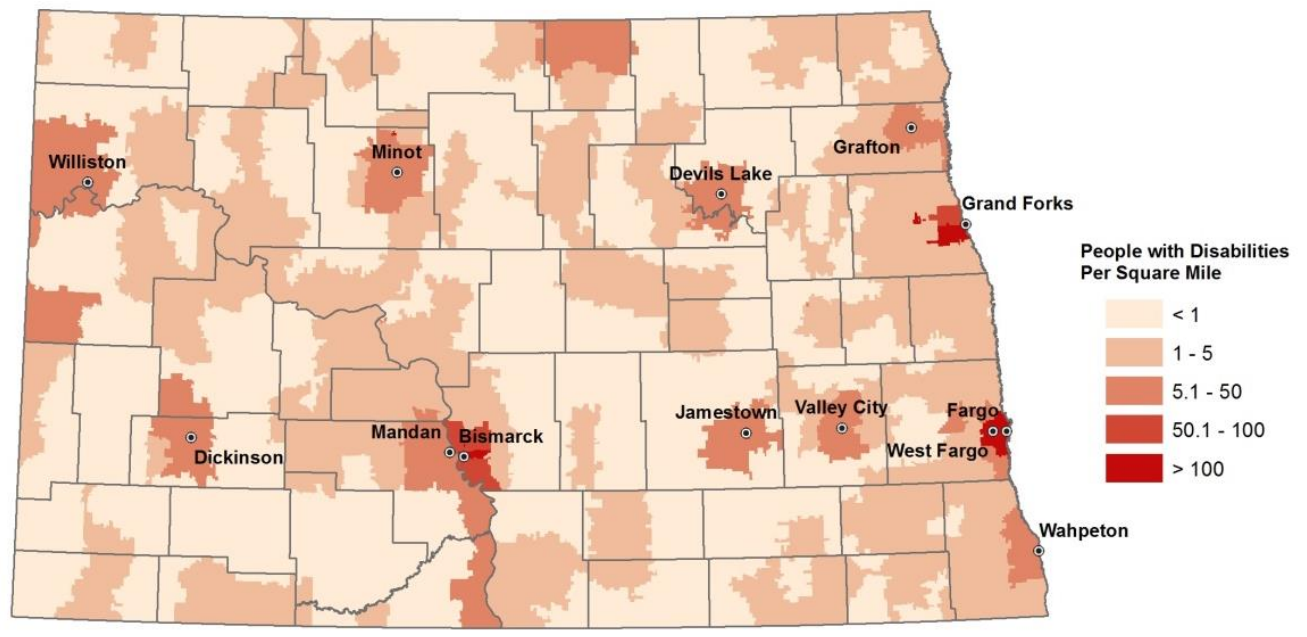

Figure 2.11 Population with Disability per Square Mile

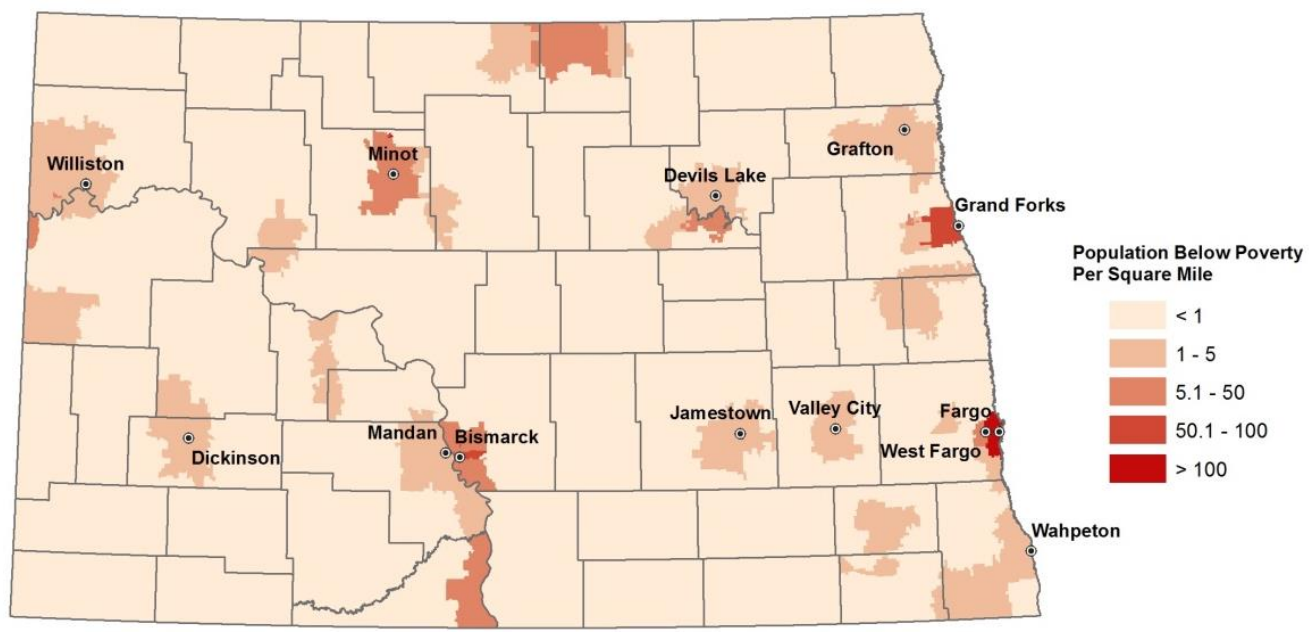

Figure 2.12 Population below Poverty Line per Square Mile 


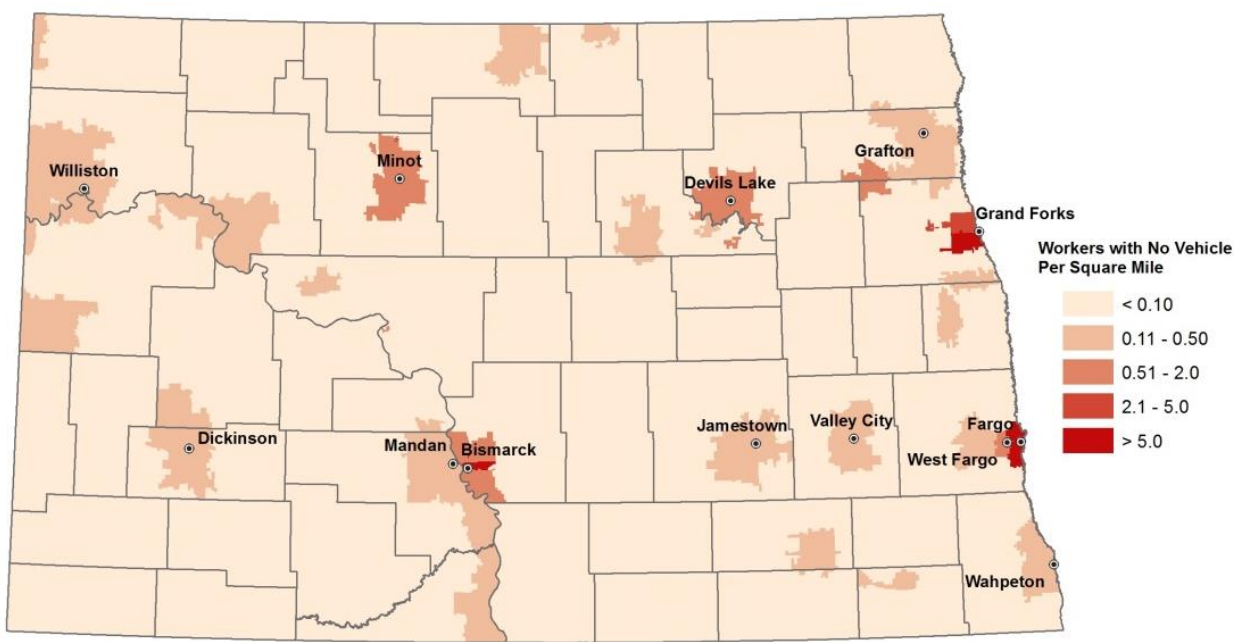

Figure 2.13 Workers without Access to a Vehicle per Square Mile

Table 2.1 provides community-specific data for all cities or places in the state with an estimated population above 1,000. These data are based on the 2008-2012 ACS 5-Year Estimates, which underestimates cities that have experienced significant growth in recent years, such as Williston, but more recent demographic data are not available. 
Table 2.1 City-Level Population and Demographic Data, 2008-2012 Estimates

\begin{tabular}{|c|c|c|c|c|c|c|c|c|c|}
\hline Place & $\begin{array}{c}\text { Total } \\
\text { Population }\end{array}$ & $\begin{array}{l}\text { Population } \\
\text { per Square } \\
\text { Mile }\end{array}$ & $\begin{array}{l}\text { Population } \\
65 \text { or Older }\end{array}$ & $\begin{array}{l}\text { Population } \\
\text { with a } \\
\text { Disability }\end{array}$ & $\begin{array}{l}\text { Population } \\
\text { Below } \\
\text { Poverty Line }\end{array}$ & $\begin{array}{c}\text { Total } \\
\text { Workers }\end{array}$ & $\begin{array}{l}\text { Workers } \\
\text { with No } \\
\text { Vehicle }\end{array}$ & $\begin{array}{c}\text { Pop } \% 65 \\
\text { or older }\end{array}$ & $\begin{array}{c}\text { Pop } \% \\
\text { Below } \\
\text { Poverty }\end{array}$ \\
\hline Fargo & 106,005 & 2,178 & 10,596 & 28,962 & 16,231 & 60,616 & 2,184 & 10.0 & 15.3 \\
\hline Bismarck & 61,941 & 1,978 & 9,455 & 19,121 & 5,824 & 33,990 & 488 & 15.3 & 9.4 \\
\hline Grand Forks & 52,773 & 2,628 & 5,414 & 13,943 & 9,466 & 28,714 & 1,262 & 10.3 & 17.9 \\
\hline Minot & 41,251 & 2,258 & 5,835 & 13,418 & 4,852 & 22,739 & 528 & 14.1 & 11.8 \\
\hline West Fargo & 25,793 & 1,753 & 2,113 & 8,370 & 1,755 & 15,567 & 34 & 8.2 & 6.8 \\
\hline Mandan & 18,365 & 1,639 & 2,598 & 6,199 & 1,782 & 10,092 & 195 & 14.1 & 9.7 \\
\hline Dickinson & 18,140 & 1,810 & 2,774 & 5,798 & 1,278 & 10,264 & 179 & 15.3 & 7.0 \\
\hline Williston & 15,553 & 1,793 & 2,083 & 5,112 & 1,332 & 8,394 & 162 & 13.4 & 8.6 \\
\hline Jamestown & 15,333 & 1,193 & 2,496 & 5,038 & 1,719 & 7,450 & 107 & 16.3 & 11.2 \\
\hline Wahpeton & 7,769 & 1,475 & 951 & 2,203 & 1,017 & 3,717 & 70 & 12.2 & 13.1 \\
\hline Devils Lake & 7,129 & 1,093 & 1,347 & 2,620 & 950 & 3,540 & 160 & 18.9 & 13.3 \\
\hline Valley City & 6,585 & 1,675 & 1,443 & 1,899 & 789 & 3,403 & 152 & 21.9 & 12.0 \\
\hline Minot AFB & 5,588 & 728 & 0 & 2,047 & 241 & 2,062 & 8 & 0.0 & 4.3 \\
\hline Grafton & 4,307 & 1,266 & 853 & 1,805 & 501 & 2,078 & 96 & 19.8 & 11.6 \\
\hline Beulah & 3,115 & 1,238 & 498 & 942 & 224 & 1,546 & 18 & 16.0 & 7.2 \\
\hline Rugby & 2,873 & 1,481 & 710 & 994 & 278 & 1,384 & 43 & 24.7 & 9.7 \\
\hline Horace & 2,608 & 237 & 180 & 973 & 68 & 1,461 & 0 & 6.9 & 2.6 \\
\hline Grand Forks AFB & 2,570 & 316 & 0 & 872 & 136 & 998 & 28 & 0.0 & 5.3 \\
\hline Lincoln & 2,494 & 2,230 & 121 & 967 & 66 & 1,454 & 35 & 4.9 & 2.6 \\
\hline Hazen & 2,412 & 1,892 & 297 & 830 & 172 & 1,314 & 4 & 12.3 & 7.1 \\
\hline Bottineau & 2,290 & 2,020 & 528 & 751 & 198 & 949 & 10 & 23.1 & 8.6 \\
\hline Lisbon & 2,199 & 978 & 483 & 857 & 323 & 1,058 & 17 & 22.0 & 14.7 \\
\hline Casselton & 2,137 & 1,126 & 217 & 853 & 83 & 1,126 & 13 & 10.2 & 3.9 \\
\hline Watford City & 2,088 & 1,474 & 364 & 852 & 97 & 997 & 5 & 17.4 & 4.6 \\
\hline Carrington & 2,050 & 970 & 470 & 632 & 240 & 1,032 & 32 & 22.9 & 11.7 \\
\hline Stanley & 1,898 & 1,035 & 313 & 594 & 49 & 936 & 0 & 16.5 & 2.6 \\
\hline Oakes & 1,877 & 1,150 & 475 & 684 & 185 & 915 & 33 & 25.3 & 9.9 \\
\hline Harvey & 1,862 & 988 & 592 & 630 & 316 & 793 & 0 & 31.8 & 17.0 \\
\hline New Town & 1,855 & 1,448 & 140 & 716 & 300 & 817 & 66 & 7.5 & 16.2 \\
\hline Belcourt & 1,832 & 305 & 201 & 913 & 731 & 488 & 0 & 11.0 & 39.9 \\
\hline Langdon & 1,817 & 1,079 & 549 & 578 & 146 & 833 & 0 & 30.2 & 8.0 \\
\hline Hillsboro & 1,809 & 1,654 & 313 & 701 & 191 & 864 & 12 & 17.3 & 10.6 \\
\hline Mayville & 1,678 & 875 & 414 & 534 & 191 & 743 & 14 & 24.7 & 11.4 \\
\hline Bowman & 1,605 & 1,048 & 405 & 543 & 149 & 800 & 5 & 25.2 & 9.3 \\
\hline Ellendale & 1,502 & 991 & 291 & 456 & 226 & 695 & 6 & 19.4 & 15.0 \\
\hline Park River & 1,491 & 686 & 373 & 524 & 238 & 647 & 3 & 25.0 & 16.0 \\
\hline Larimore & 1,433 & 2,411 & 211 & 552 & 149 & 705 & 3 & 14.7 & 10.4 \\
\hline Cavalier & 1,385 & 1,688 & 349 & 495 & 56 & 625 & 6 & 25.2 & 4.0 \\
\hline New Rockford & 1,304 & 847 & 351 & 456 & 187 & 619 & 21 & 26.9 & 14.3 \\
\hline Washburn & 1,252 & 663 & 197 & 401 & 51 & 639 & 8 & 15.7 & 4.1 \\
\hline Rolla & 1,240 & 864 & 189 & 508 & 406 & 531 & 3 & 15.2 & 32.7 \\
\hline Shell Valley & 1,227 & 82 & 33 & 569 & 320 & 481 & 0 & 2.7 & 26.1 \\
\hline Hettinger & 1,208 & 1,397 & 313 & 368 & 112 & 632 & 6 & 25.9 & 9.3 \\
\hline Garrison & 1,199 & 866 & 393 & 353 & 132 & 528 & 8 & 32.8 & 11.0 \\
\hline Walhalla & 1,191 & 1,083 & 288 & 510 & 130 & 520 & 0 & 24.2 & 10.9 \\
\hline Fort Totten & 1,165 & 132 & 40 & 630 & 790 & 225 & 13 & 3.4 & 67.8 \\
\hline Kenmare & 1,132 & 910 & 229 & 434 & 113 & 493 & 0 & 20.2 & 10.0 \\
\hline Parshall & 1,123 & 2,036 & 176 & 518 & 281 & 553 & 23 & 15.7 & 25.0 \\
\hline Velva & 1,091 & 1,317 & 257 & 472 & 275 & 449 & 16 & 23.6 & 25.2 \\
\hline Hankinson & 1,091 & 685 & 255 & 380 & 151 & 548 & 0 & 23.4 & 13.8 \\
\hline Burlington & 1,060 & 1,655 & 106 & 407 & 41 & 599 & 6 & 10.0 & 3.9 \\
\hline Crosby & 1,053 & 766 & 276 & 330 & 107 & 581 & 0 & 26.2 & 10.2 \\
\hline Cooperstown & 1,040 & 1,070 & 271 & 320 & 71 & 542 & 5 & 26.1 & 6.8 \\
\hline Cando & 1,036 & 1,637 & 255 & 373 & 61 & 528 & 9 & 24.6 & 5.9 \\
\hline Linton & 1,035 & 1,386 & 363 & 413 & 142 & 499 & 24 & 35.1 & 13.7 \\
\hline
\end{tabular}




\section{MOBILITY NEEDS INDEX}

The population and demographic data presented in the previous section provides guidance for determining where the greatest needs for mobility services exist. There is no generally accepted, lowcost methodology for accurately measuring the mobility needs in a community. Previous research by Mielke et al. (2005) developed a Mobility Needs Index to identify counties in North Dakota with the greatest need for mobility services. This study uses the previously developed model and applies it to both counties and zip codes using updated data.

As noted in the previous report, this methodology is only an attempt to measure needs associated with identifiable demographic groups. This measurement does not suggest that all related needs are unmet. To the contrary, some cities may have systems and services in place that satisfy many residents' mobility needs.

The factors deemed important for determining mobility needs are those discussed in the previous section: total population, population aged 65 or older, population with a disability, population below the poverty line, and population of workers without access to a vehicle. Index values were calculated at both the county level and zip code level. First, population densities were calculated for each of these five factors. Second, the geographic areas were ranked from highest population densities to lowest population densities and grouped into five equally sized classes, using quintile values, for each of the five factors. Geographic areas in the lowest $20 \%$ were given a value equal to 1 , the next $20 \%$ were given a value equal to 2 , and so on, while the highest $20 \%$ were given a value of 5 . In the last step, the five values were averaged for each geographic area to produce its Mobility Needs Index. The process thus ranks all regions on a scale of 1 to 5 with higher values identifying areas with greater mobility needs. See Mielke et al. (2005) for more details about the method. This study differs from Mielke et al. (2005) by using a 1 to 5 scale instead of a 1 to 4 scale.

Values calculated for each of North Dakota's counties are presented in Figure 3.1. The results are relatively intuitive, as the more highly populated counties have the highest values. Cass, Burleigh, Morton, Stark, Ward, Ramsey, and Grand Forks counties all have a value of 5, followed by Richland with 4.75 and Williams and Rolette with 4.5. Some lower-population counties rank higher because of high concentrations of transportation-disadvantaged populations. Sioux County, for example, ranks higher because of a higher density of low-income and no-vehicle populations, despite a lower density of older adults. To show greater detail, the Mobility Needs Index was also calculated at the zip code level, as shown in Figure 3.2.

As indicated earlier, this index is an attempt to measure concentrations of mobility needs. It is not a measure of unmet needs. Comparing these calculated indices with the actual level of transit services in each county, zip code, or community will provide information on where there is unmet need for service. 


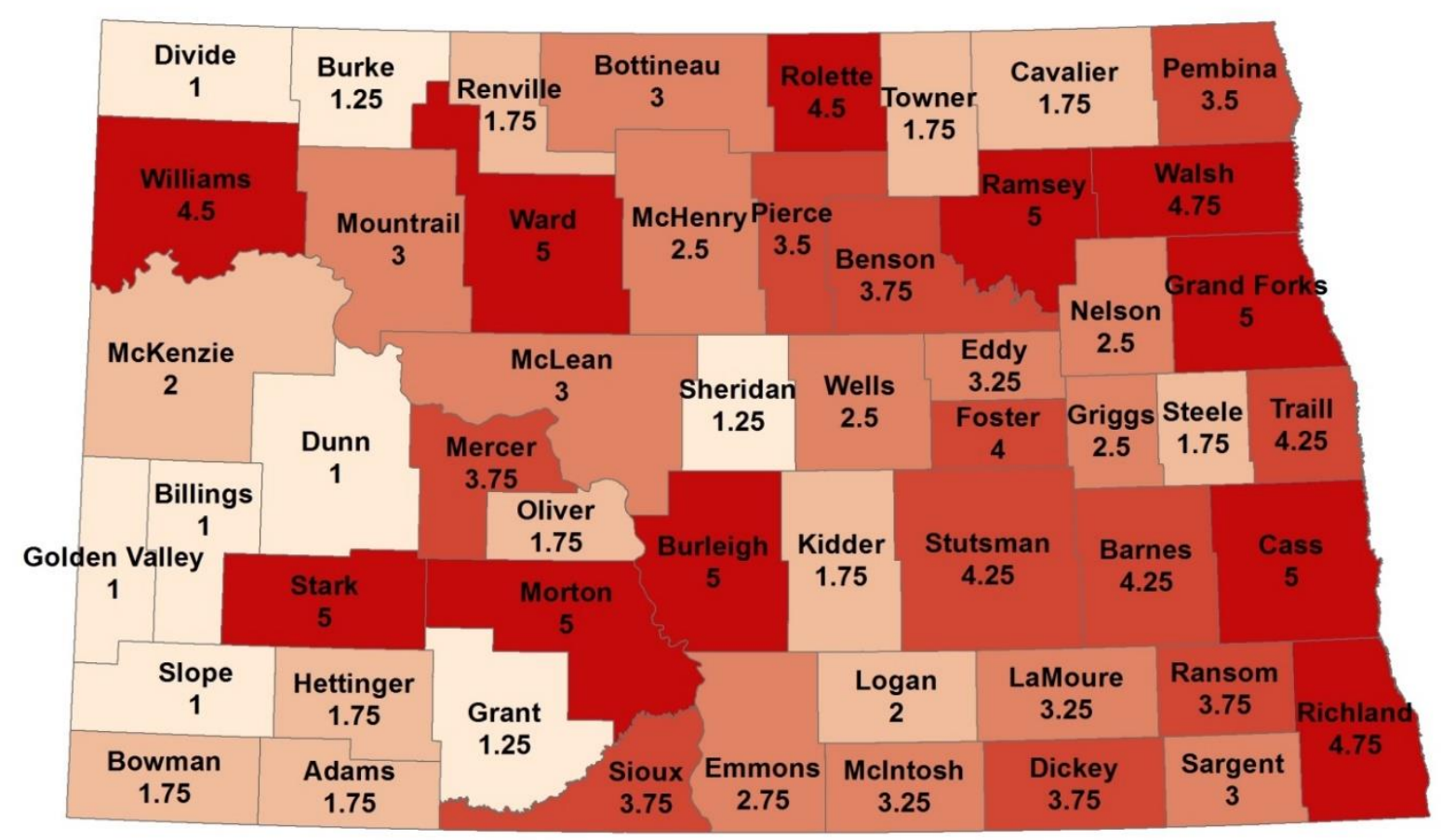

Figure 3.1 Mobility Needs Index Map, County Level

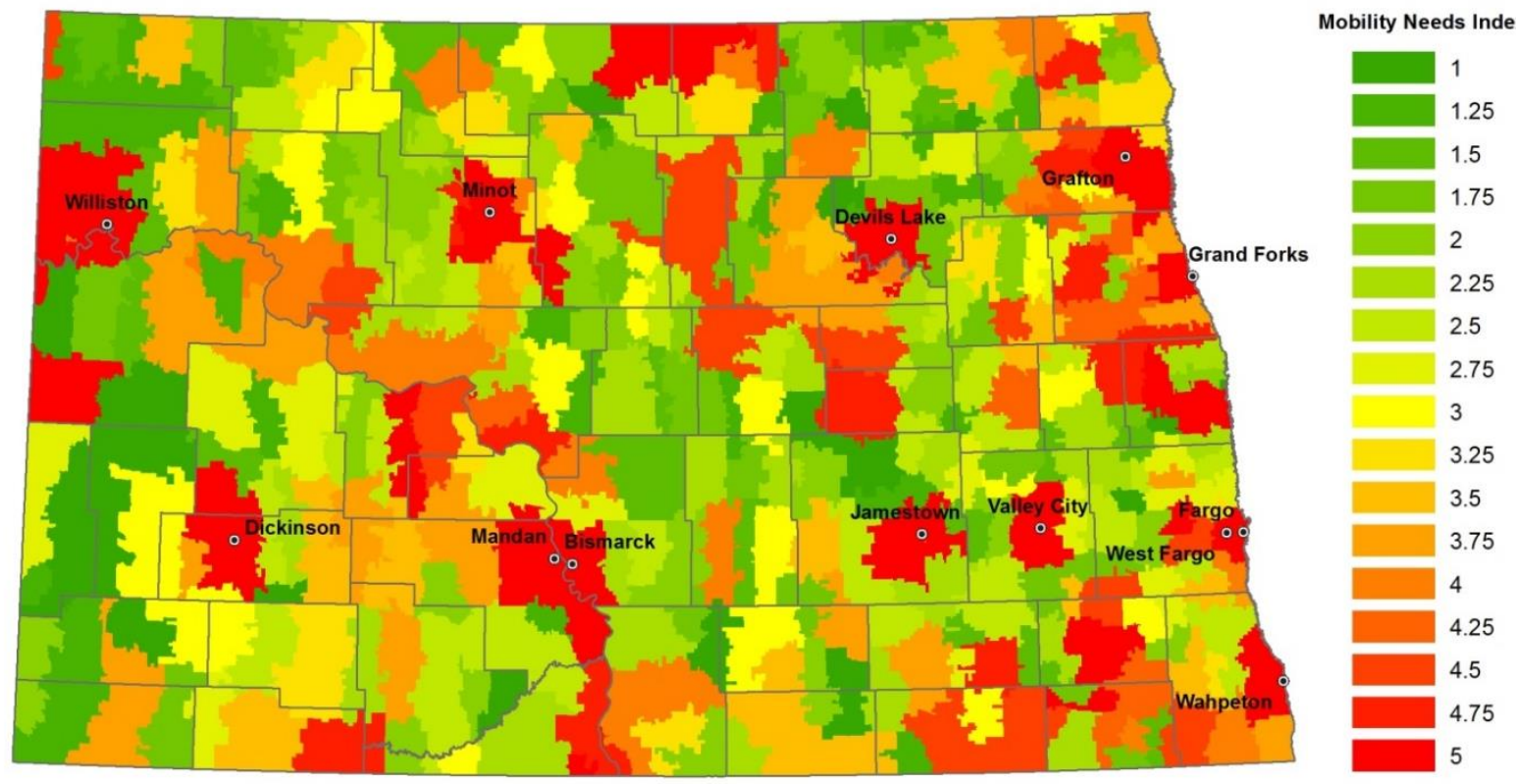

Figure 3.2 Mobility Needs Index Map, Zip Code Level 


\section{SURVEY METHODOLOGY AND ADMINISTRATION}

Two surveys were conducted in August and September of 2014 to gather information about existing transit services, how well those services are meeting the needs of the state's residents, and the issues and challenges facing transit providers across the state. The first was a survey of all transit agencies in the state, and the second was a survey of human service agencies.

The transit agency survey was sent to every transit provider in North Dakota to collect information on current levels of service, needed facility upgrades, need for new service, challenges to providing new service, staffing capabilities, and other issues. The survey was designed with input from the steering committee and conducted online. It was distributed via email to the 33 agencies identified by the NDDOT. Responses were received from 27 of these agencies. A complete list of transit agencies is shown in Table 4.1, along with information on areas served and whether the agency completed the survey.

Table 4.1 Transit Agencies in North Dakota

\begin{tabular}{|c|c|c|}
\hline Transit Agency & Area Served & $\begin{array}{l}\text { Completed } \\
\text { survey }\end{array}$ \\
\hline Benson County Transportation & Benson, Wells, Pierce, and Ramsey Counties & Yes \\
\hline Bis-Man Transit Board & Cities of Bismarck, Mandan, and Lincoln & Yes \\
\hline Cando Transportation & Towner County & No \\
\hline Cavalier County Transit & Cavalier County & Yes \\
\hline Devils Lake Transit /Eddy Co Transit & Ramsey and Eddy Counties & Yes \\
\hline Dickey County Transportation & Dickey County & Yes \\
\hline Dickinson Public Transit (Elder Care) & Stark, Morton, and Burleigh Counties & Yes \\
\hline Fargo Metro Area Transit & Cities of Fargo and West Fargo & Yes \\
\hline Glen Ullin City Transportation & Morton County & Yes \\
\hline Golden Valley/Billings Cncl. On Aging & Golden Valley and Billings Counties & No \\
\hline Grand Forks - Cities Area Transit & City of Grand Forks & Yes \\
\hline Handi-Wheels Transportation & Cities of Fargo and West Fargo & Yes \\
\hline Hazen Busing & Mercer and Oliver Counties & Yes \\
\hline James River Public Transit & Stutsman, Wells, and Sheridan Counties & Yes \\
\hline Jamestown, City of & City of Jamestown & No \\
\hline Kenmare Wheels \& Meals, Inc. & City of Kenmare & Yes \\
\hline Kidder/Emmons Senior Services & Kidder County & Yes \\
\hline Minot, City of & City of Minot & Yes \\
\hline Nelson County Transportation & Nelson and rural Grand Forks Counties & Yes \\
\hline Northwest Dakota Public Transit & Divide, Williams, and McKenzie Counties & Yes \\
\hline Nutrition United/Rolette Co. Transp. & Rolette County & No \\
\hline Pembina County Meals \& Trans & Pembina County & Yes \\
\hline Souris Basin Transportation & $\begin{array}{l}\text { Burke, Renville, Mountrail, Ward, Bottineau, Pierce, and } \\
\text { McHenry Counties }\end{array}$ & Yes \\
\hline South Central Adult Services & $\begin{array}{l}\text { Barnes, LaMoure, Foster, Logan, McIntosh, Griggs, Emmons, } \\
\text { Stutsman, and Cass Counties }\end{array}$ & Yes \\
\hline Southwest Transportation Services & Adams, Bowman, Hettinger, and Slope Counties & Yes \\
\hline Spirit Lake Transit & Benson County and Devils Lake & Yes \\
\hline Standing Rock Public Transportation & Sioux, Morton, and Burleigh Counties & Yes \\
\hline Trenton Indian Services Area & Williams County & No \\
\hline Turtle Mountain Transit & Rolette County & No \\
\hline Valley Senior Services & $\begin{array}{l}\text { Cass, Traill, Steele, Richland, Ransom, Sargent and Grand } \\
\text { Forks Counties }\end{array}$ & Yes \\
\hline Walsh County Transportation & Walsh, Pembina, and Grand Forks Counties & Yes \\
\hline West River Transit & $\begin{array}{l}\text { Burleigh, Morton, Oliver, Mercer, McLean, Dunn, and Grant } \\
\text { Counties }\end{array}$ & Yes \\
\hline Wildrose Senior Transportation & Williams and Divide Counties & Yes \\
\hline
\end{tabular}


A second survey was conducted of human service agencies that serve transportation-disadvantaged populations in North Dakota. This survey gathered input from these agencies regarding the transportation needs of the people they serve. The findings provide supplemental information about the transportation needs across the state.

The survey was conducted online and distributed via email. The survey was sent to the eight regional human service centers, the four Centers for Independent Living, and organizations belonging to the North Dakota Disabilities Advocacy Consortium and the North Dakota Association of Community Providers. A total of 40 responses were received. Full results to the survey are shown in Appendix D.

Most of these organizations serve people with disabilities, and many serve older adults, low-income individuals, children and families, people with addictions, the homeless, and people with mental health issues. Respondents were asked to identify the counties their agency serves. Figure 4.1 shows the number of responding agencies serving each county, including five agencies that serve the entire state. Responses were received from agencies across the state, but the greatest number of responses came from the north central and northwest regions.

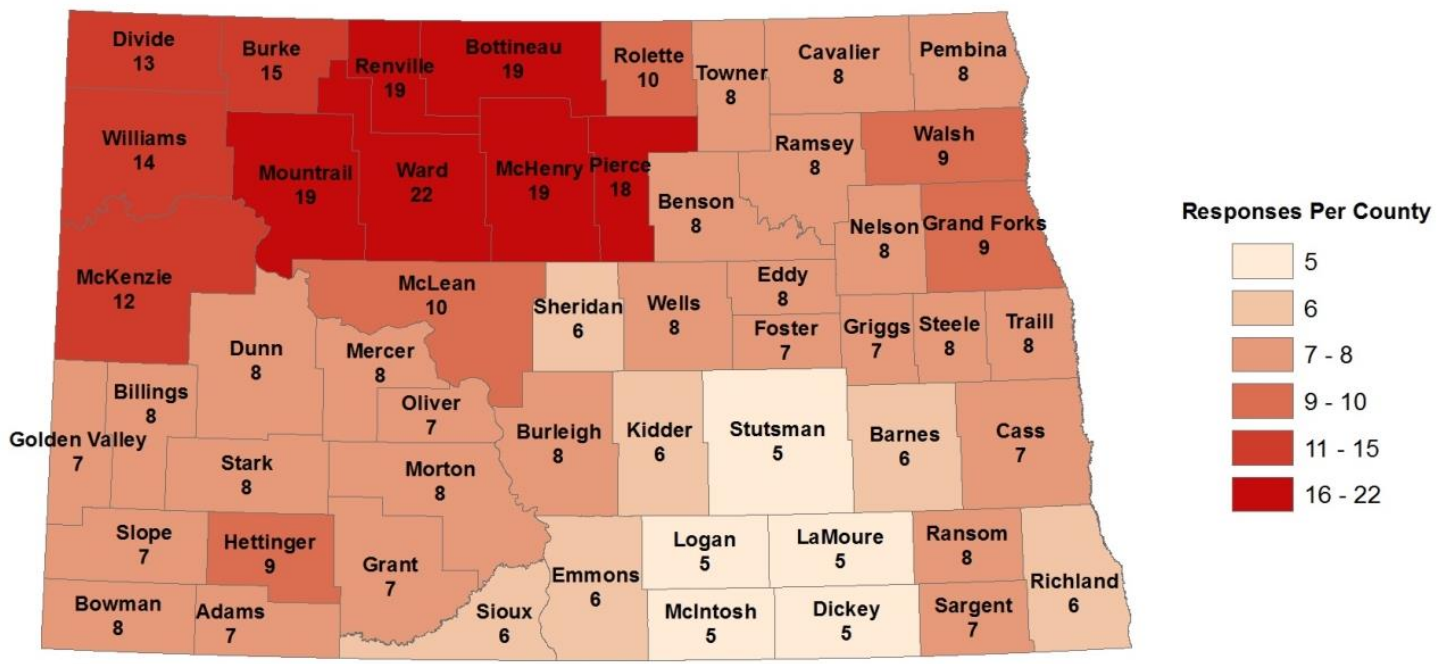

Figure 4.1 Responses to Survey of Human Service Agencies by County 


\section{EXISTING LEVELS OF TRANSIT SERVICE}

Existing levels of transit service for the state were analyzed by examining National Transit Database (NTD) data and transit agency survey data. NTD data on ridership, vehicle revenue miles and hours of service, number of vehicles in service, and various performance measures were analyzed. The transit agency survey provided information on service coverage, span of service, types of service provided, and other service characteristics.

\subsection{Data from the National Transit Database}

Data for urban transit agencies receiving section 5307 Urbanized Area Formula Program funding and rural transit agencies receiving section 5311 Non-Urbanized Area Formula Program funding are available from the NTD and Rural NTD, respectively. Data from transit providers receiving funding under the section 5310, Transportation for Elderly Person and Persons with Disabilities, program are not available from the NTD. The most recent data available from the NTD at the time of this report is for 2012. NTD data for rural transit agencies for 2013 were collected from the NDDOT, and 2013 data were also obtained from the transit agencies in Fargo, Bismarck, and Grand Forks.

\subsubsection{Urban National Transit Database}

North Dakota has three urban transit providers located in Fargo-West Fargo, Bismarck-Mandan, and Grand Forks. Metro Area Transit (MATBUS) is the transit system serving Fargo and West Fargo. In Bismarck-Mandan, Capital Area Transit (CAT) is the fixed-route system and Bis-Man Paratransit is the paratransit system. Grand Forks is served by Cities Area Transit (CAT). Operating, financial, and fleet statistics for both fixed-route and demand-response services from these transit agencies were obtained from the NTD for 2003-2012. Detailed data are presented in Appendix E. Data for 2012 for fixed-route and demand-response systems are shown in Tables 5.1 and 5.2, and total operating and capital funding data, by source for 2012, is presented in Table 5.3. 
Table 5.1 Urban Fixed-Route Transit Data, 2012

\begin{tabular}{lccc}
\hline & $\begin{array}{c}\text { Fargo: } \\
\text { Metro Area } \\
\text { Transit }\end{array}$ & $\begin{array}{c}\text { Grand Forks: } \\
\text { Cities Area } \\
\text { Transit }\end{array}$ & $\begin{array}{c}\text { Bismarck: } \\
\text { Bis-Man } \\
\text { Transit }\end{array}$ \\
\hline Service Data & & & \\
Unlinked Passenger Trips & $1,604,693$ & 371,242 & 141,067 \\
Passenger Miles Traveled & $5,050,293$ & $1,524,118$ & 674,300 \\
Vehicle Revenue Miles & 857,329 & 382,788 & 302,977 \\
Vehicle Revenue Hours & 66,560 & 25,292 & 19,787 \\
Total Operating Expense (million \$) & 4.98 & 1.86 & 1.39 \\
Fleet Data & & & \\
Vehicles Available for Maximum Service & 28 & 12 & 10 \\
Average Fleet Age (years) & 6.6 & 4.8 & 6.4 \\
Performance Measures & & & \\
Unlinked Passenger Trips per Revenue Mile & 1.87 & 0.97 & 0.47 \\
Unlinked Passenger Trips per Revenue Hour & 24.11 & 14.68 & 7.13 \\
Unlinked Passenger Trips per Total Vehicles & 57,310 & 30,937 & 14,107 \\
Vehicle Revenue Miles per Total Vehicles & 30,619 & 31,899 & 30,298 \\
Vehicle Revenue Hours per Total Vehicles & 2,377 & 2,108 & 1,979 \\
Passenger Miles per Vehicle Revenue Mile & 5.89 & 3.98 & 2.23 \\
Operating Cost per Trip & 3.11 & 5.00 & 9.85 \\
Operating Cost per Vehicle Revenue Mile & 5.81 & 4.85 & 4.59 \\
Operating Cost per Vehicle Revenue Hour & 74.88 & 73.38 & 70.21 \\
Farebox Recovery Ratio & $13 \%$ & $12 \%$ & $6 \%$ \\
\hline
\end{tabular}

Source: National Transit Database 
Table 5.2 Urban Demand-Response Transit Data, 2012

\begin{tabular}{|c|c|c|c|}
\hline & $\begin{array}{c}\text { Fargo: } \\
\text { Metro Area } \\
\text { Transit } \\
\end{array}$ & $\begin{array}{c}\text { Grand Forks: } \\
\text { Cities Area } \\
\text { Transit } \\
\end{array}$ & $\begin{array}{c}\text { Bismarck: } \\
\text { Bis-Man } \\
\text { Transit } \\
\end{array}$ \\
\hline \multicolumn{4}{|l|}{ Service Data } \\
\hline Unlinked Passenger Trips & 54,543 & 55,212 & 168,121 \\
\hline Passenger Miles Traveled & 297,907 & 170,704 & 635,485 \\
\hline Vehicle Revenue Miles & 336,514 & 204,665 & 623,172 \\
\hline Vehicle Revenue Hours & 25,442 & 20,683 & 44,507 \\
\hline Total Operating Expense (million \$) & 1.25 & 0.97 & 1.88 \\
\hline \multicolumn{4}{|l|}{ Fleet Data } \\
\hline Vehicles Available for Maximum Service & 14 & 14 & 31 \\
\hline Average Fleet Age (years) & 3.7 & 2.2 & 5.3 \\
\hline \multicolumn{4}{|l|}{ Performance Measures } \\
\hline Unlinked Passenger Trips per Revenue Mile & 0.16 & 0.27 & 0.27 \\
\hline Unlinked Passenger Trips per Revenue Hour & 2.14 & 2.67 & 3.78 \\
\hline Unlinked Passenger Trips per Total Vehicles & 3,896 & 2,629 & 5,423 \\
\hline Vehicle Revenue Miles per Total Vehicles & 24,037 & 14,619 & 20,102 \\
\hline Vehicle Revenue Hours per Total Vehicles & 1,817 & 1,477 & 1,436 \\
\hline Passenger Miles per Vehicle Revenue Mile & 0.89 & 0.83 & 1.02 \\
\hline Operating Cost per Trip & 22.86 & 17.54 & 11.18 \\
\hline Operating Cost per Vehicle Revenue Mile & 3.71 & 4.73 & 3.02 \\
\hline Operating Cost per Vehicle Revenue Hour & 49.01 & 46.83 & 42.23 \\
\hline Farebox Recovery Ratio & $25 \%$ & $17 \%$ & $20 \%$ \\
\hline
\end{tabular}

Source: National Transit Database 
Table 5.3 Urban Transit Funding Data, by Source, 2012

\begin{tabular}{|c|c|c|c|c|c|c|}
\hline \multirow{2}{*}{$\begin{array}{l} \\
\text { Operating Funds b } \\
\text { Source }\end{array}$} & \multicolumn{2}{|c|}{$\begin{array}{c}\text { Fargo: } \\
\text { Metro Area Transit }\end{array}$} & \multicolumn{2}{|c|}{$\begin{array}{c}\text { Grand Forks: } \\
\text { Cities Area Transit }\end{array}$} & \multicolumn{2}{|c|}{$\begin{array}{c}\text { Bismarck: } \\
\text { Bis-Man Transit }\end{array}$} \\
\hline & (thousand \$) & (\%) & (thousand \$) & (\%) & (thousand \$) & (\%) \\
\hline Federal & 2,007 & $32 \%$ & 1,134 & $40 \%$ & 1,440 & $44 \%$ \\
\hline State & 574 & $9 \%$ & 191 & $7 \%$ & 513 & $16 \%$ \\
\hline Local & 1,599 & $26 \%$ & 794 & $28 \%$ & 720 & $22 \%$ \\
\hline Fare Revenue & 965 & $15 \%$ & 375 & $13 \%$ & 461 & $14 \%$ \\
\hline Other & 1,086 & $17 \%$ & 329 & $12 \%$ & 135 & $4 \%$ \\
\hline $\begin{array}{l}\quad \text { Total } \\
\text { Capital Funds by } \\
\text { Source }\end{array}$ & 6,231 & $100 \%$ & 2,825 & $100 \%$ & 3,269 & $100 \%$ \\
\hline Federal & 105 & $81 \%$ & 339 & $80 \%$ & 589 & $100 \%$ \\
\hline State & 0 & $0 \%$ & 5 & $1 \%$ & 0 & $0 \%$ \\
\hline Local & 25 & $19 \%$ & 75 & $18 \%$ & 0 & $0 \%$ \\
\hline Other & 0 & $0 \%$ & 6 & $1 \%$ & 0 & $0 \%$ \\
\hline Total & 131 & $100 \%$ & 423 & $100 \%$ & 589 & $100 \%$ \\
\hline
\end{tabular}

Source: National Transit Database

\subsubsection{Rural National Transit Database}

Table 5.4 provides an overview of data for rural transit providers in North Dakota receiving Section 5311 rural transit funding, as reported in the Rural NTD for 2009-2012. The data show 31 rural transit agencies in 2012 that reported to the Rural NTD. Table 5.5 provides agency-level data for total rides, vehicle miles, and vehicle hours for each agency reporting to the Rural NTD for 2009-2013, with 2013 data included where available. Tables 5.6-5.8 provide additional agency-level data for fleet statistics, operating expenses, and performance measures. 
Table 5.4 Rural Transit Agencies: Statewide Data

\begin{tabular}{|c|c|c|c|c|}
\hline & 2009 & 2010 & 2011 & 2012 \\
\hline Number of Agencies & 37 & 34 & 31 & 31 \\
\hline Counties served (\%) & $100 \%$ & $100 \%$ & $100 \%$ & $100 \%$ \\
\hline Ridership (thousand rides) & 673 & 704 & 756 & 724 \\
\hline Vehicles Miles (thousand miles) & 2,852 & 3,182 & 3,410 & 3,249 \\
\hline Vehicle Hours (thousand hours) & 231 & 278 & 246 & 237 \\
\hline \multicolumn{5}{|l|}{ Capital Funding (thousand dollars) } \\
\hline Local & 123 & 83 & 415 & 296 \\
\hline State & 178 & 82 & 76 & 1 \\
\hline Federal & 675 & 1,178 & 3,186 & 5,256 \\
\hline \multicolumn{5}{|l|}{ Operating Funding (thousand dollars) } \\
\hline Local & 718 & 601 & 1,248 & 1,001 \\
\hline State & 2,084 & 2,000 & 1,946 & 2,267 \\
\hline Federal & 2,859 & 3,417 & 3,821 & 3,719 \\
\hline Number of Vehicles & 204 & 207 & 221 & 217 \\
\hline ADA Vehicles & $75 \%$ & $75 \%$ & $79 \%$ & $81 \%$ \\
\hline Average Vehicle Age & 7.0 & 7.3 & 6.1 & 6.9 \\
\hline Average Vehicle Length & 21.1 & 20.8 & 20.5 & 20.5 \\
\hline Average Vehicle Capacity & 11.9 & 11.7 & 11.4 & 11.4 \\
\hline Trips Per Vehicle (thousands) & 3.3 & 3.4 & 3.4 & 3.3 \\
\hline Miles Per Vehicle (thousands) & 14.0 & 15.4 & 15.4 & 15.0 \\
\hline Hours Per Vehicle (thousands) & 1.1 & 1.3 & 1.1 & 1.1 \\
\hline Trips Per Vehicle Mile & 0.24 & 0.22 & 0.22 & 0.22 \\
\hline Trips Per Vehicle Hour & 2.9 & 2.5 & 3.1 & 3.1 \\
\hline Operating Expense Per Trip, Median & 11.01 & 13.16 & 13.74 & 15.63 \\
\hline Operating Expense Per Mile, Median & 2.78 & 2.73 & 3.20 & 3.01 \\
\hline Operating Expense Per Hour, Median & 27.02 & 28.38 & 37.05 & 34.44 \\
\hline Farebox Recovery Ratio, Median & 0.10 & 0.09 & 0.08 & 0.10 \\
\hline
\end{tabular}




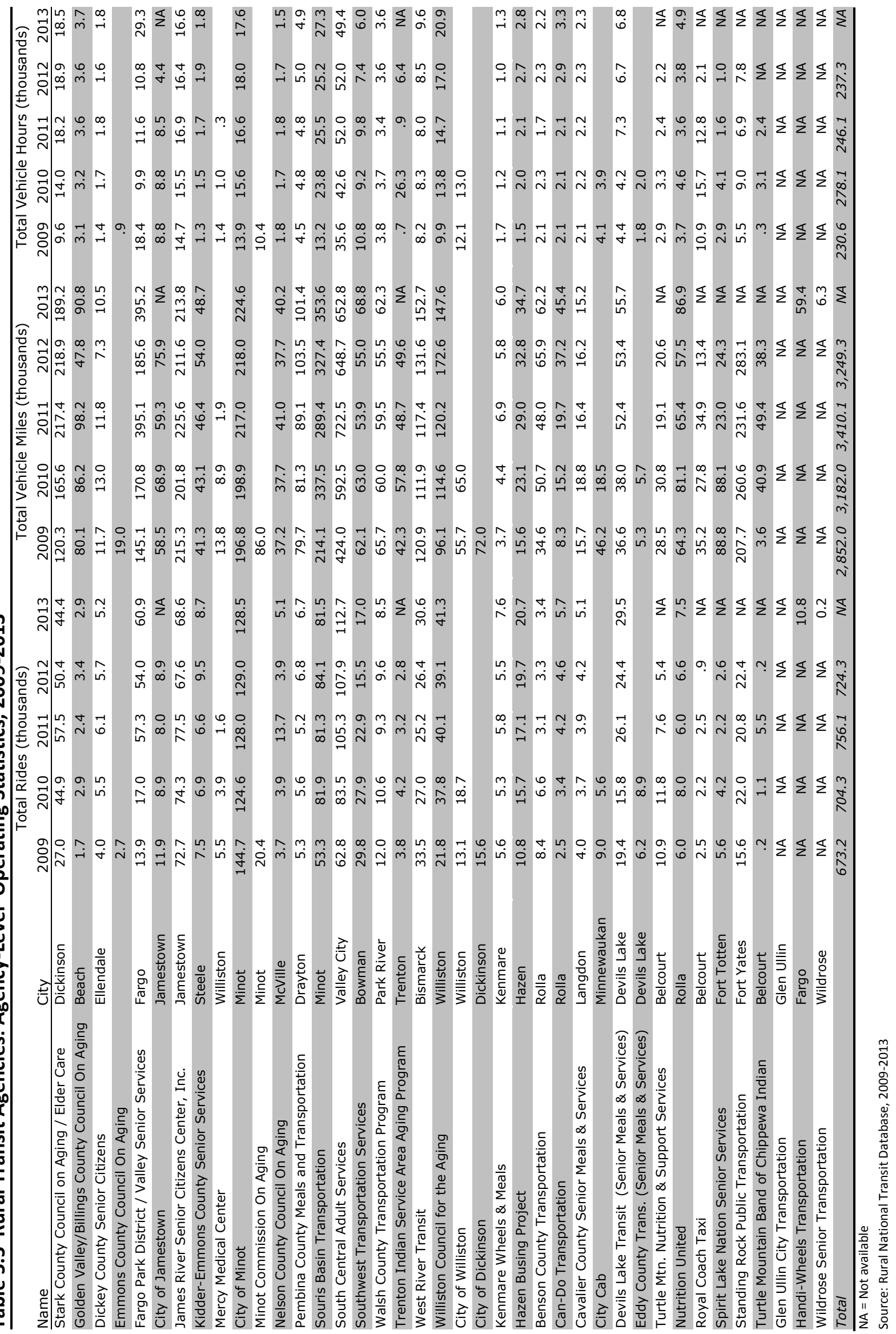




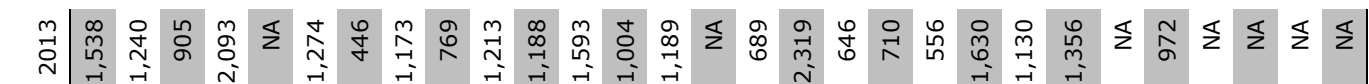

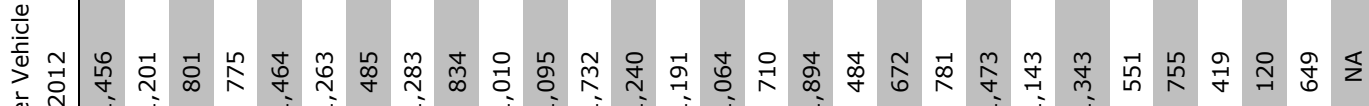
西

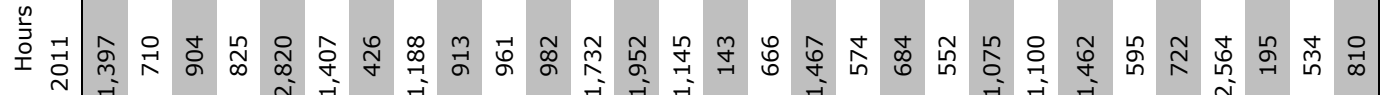

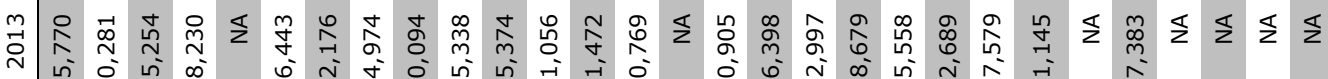

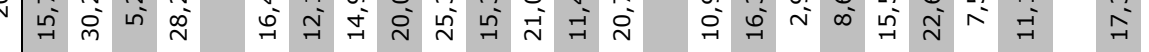

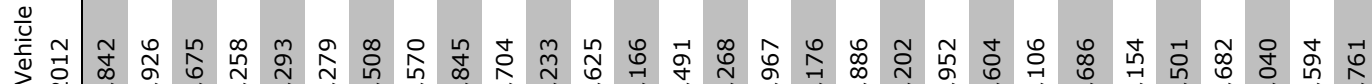

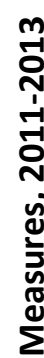

㠃 它

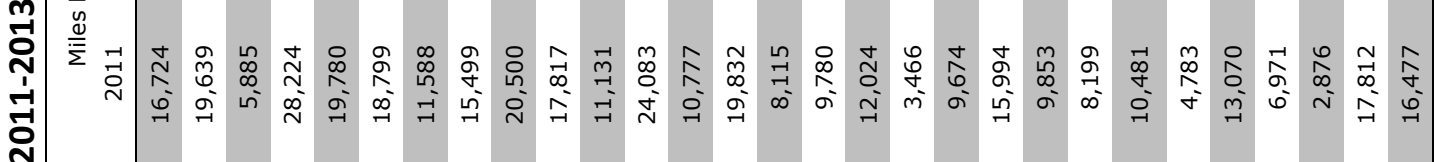

产 茎

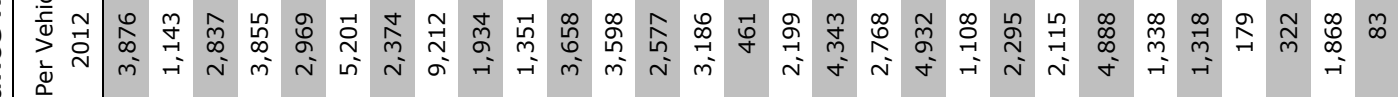

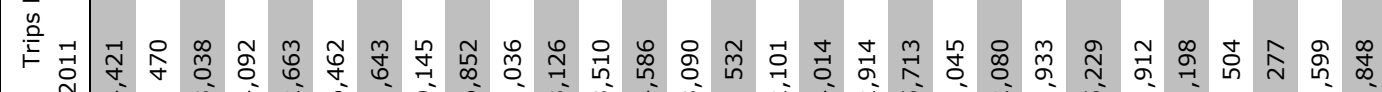

氙

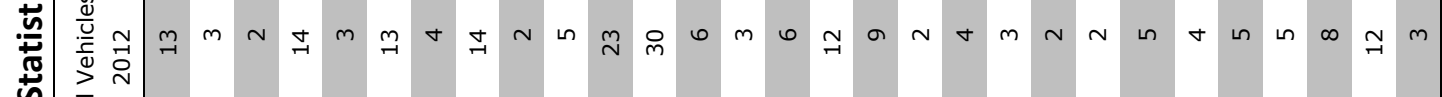
岂离

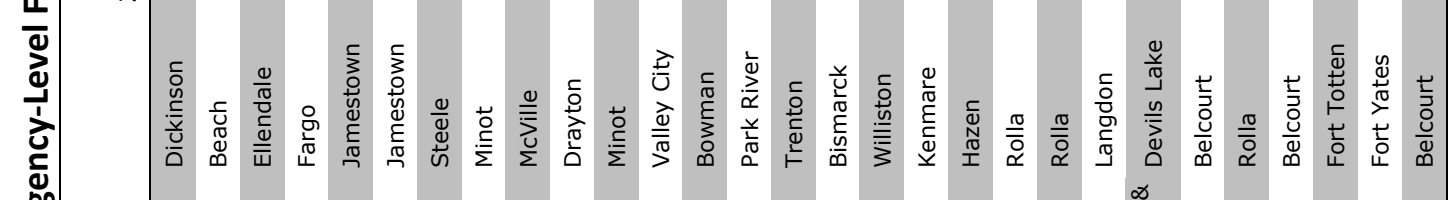

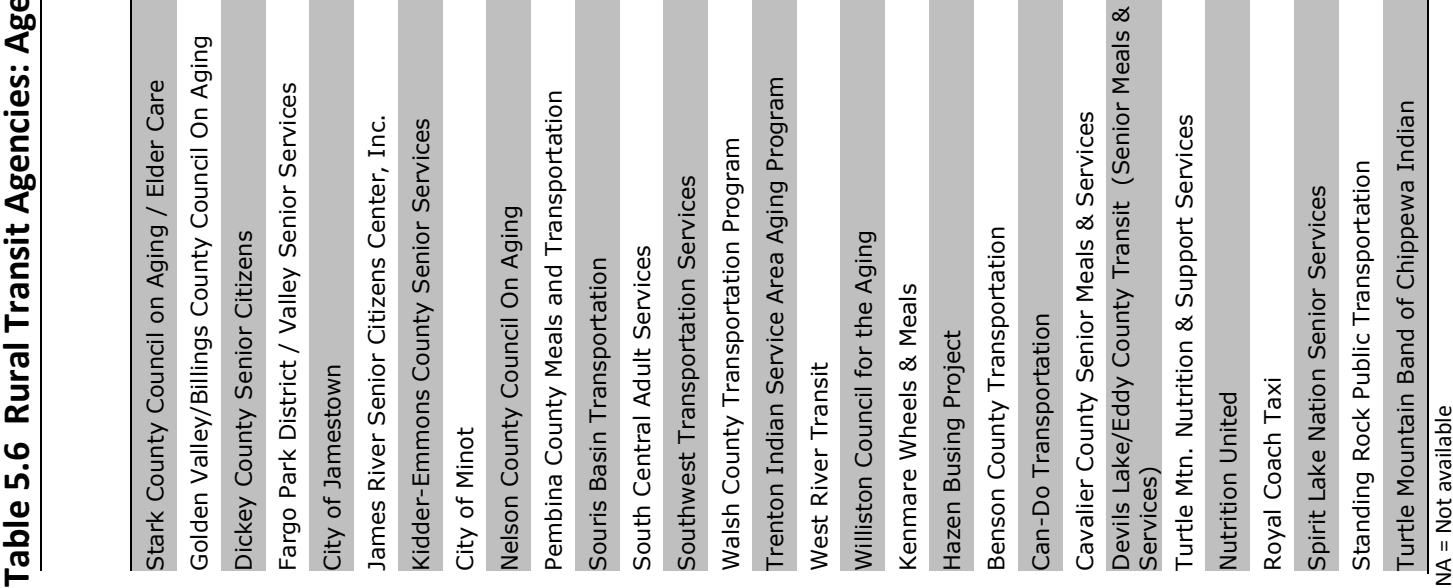




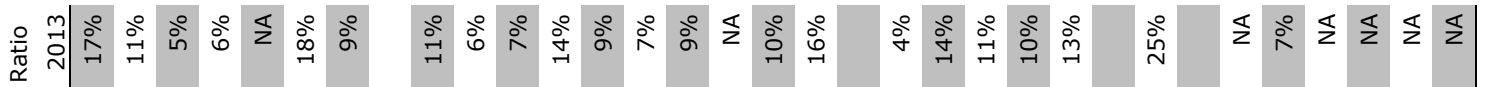

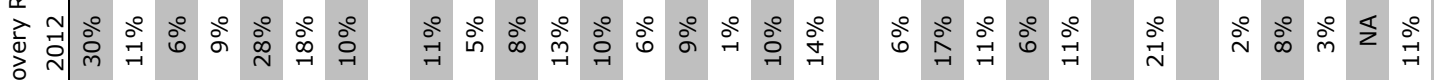

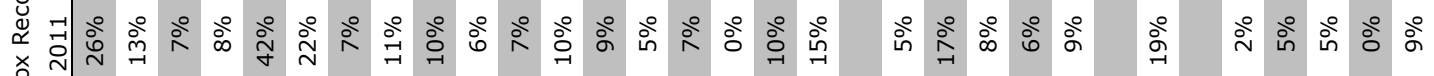

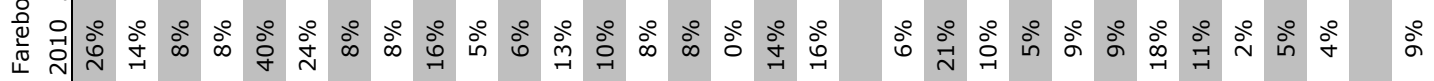

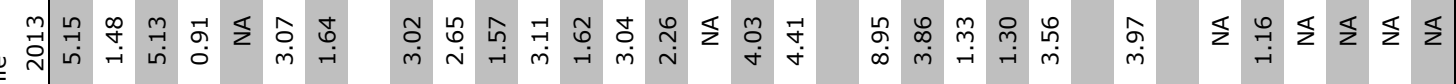
竞

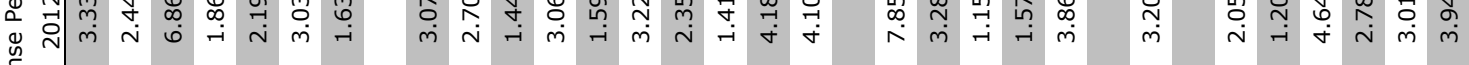
这 $=0$

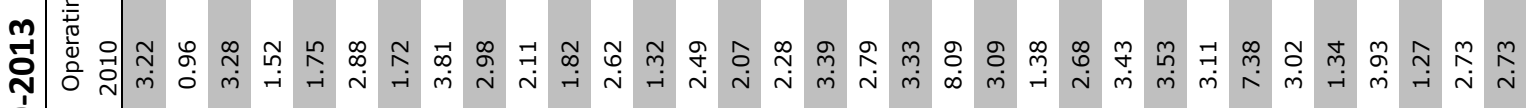

은

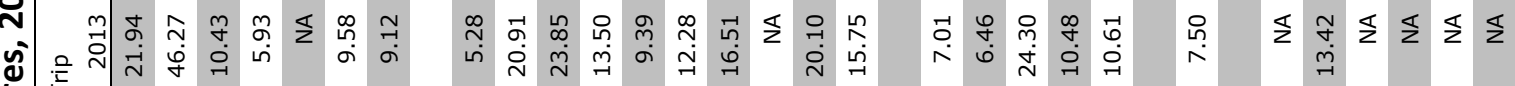

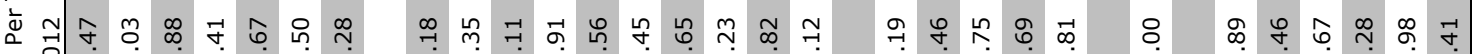

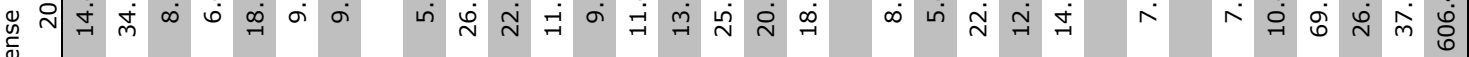

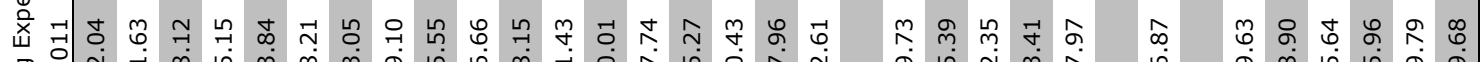

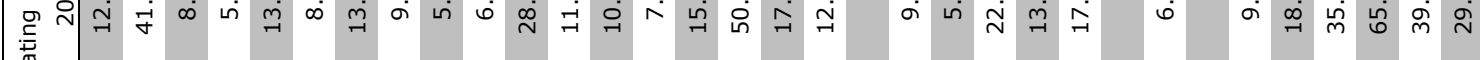

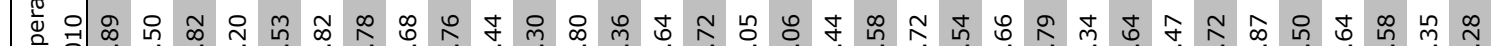

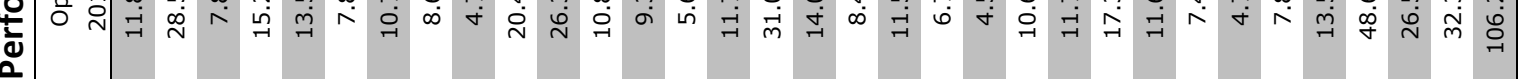

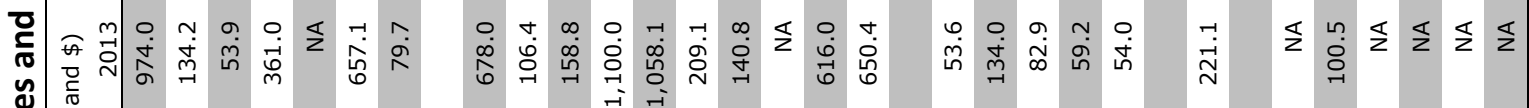

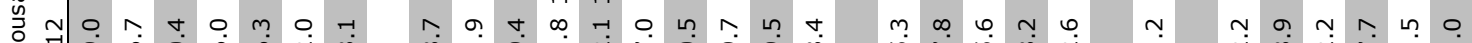

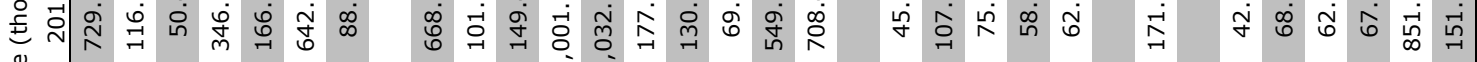

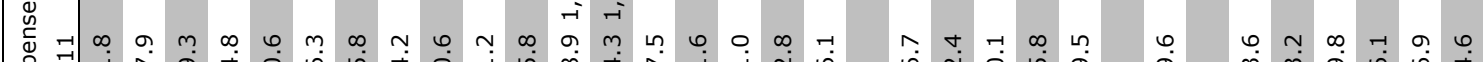

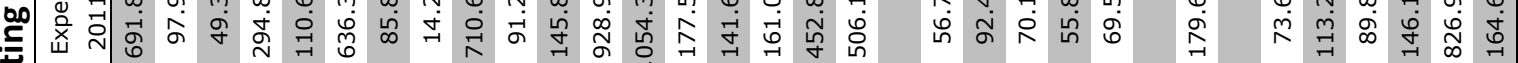

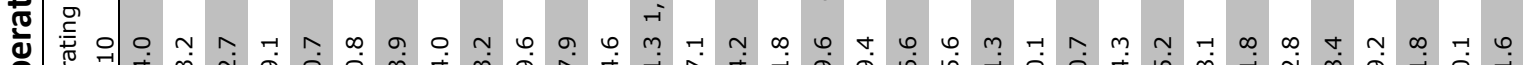

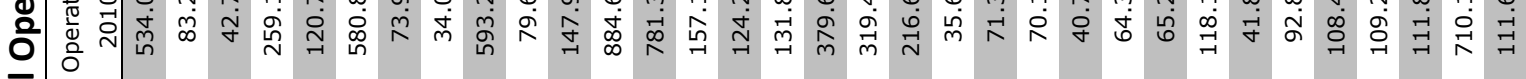

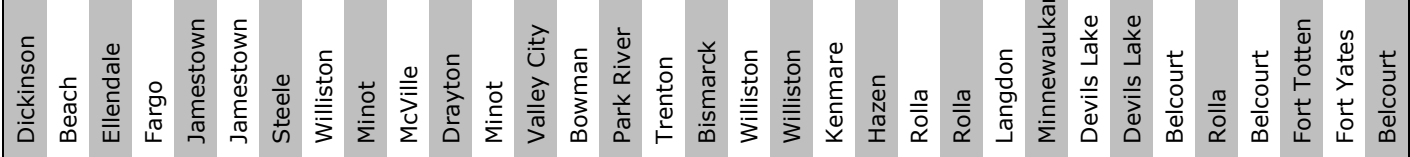

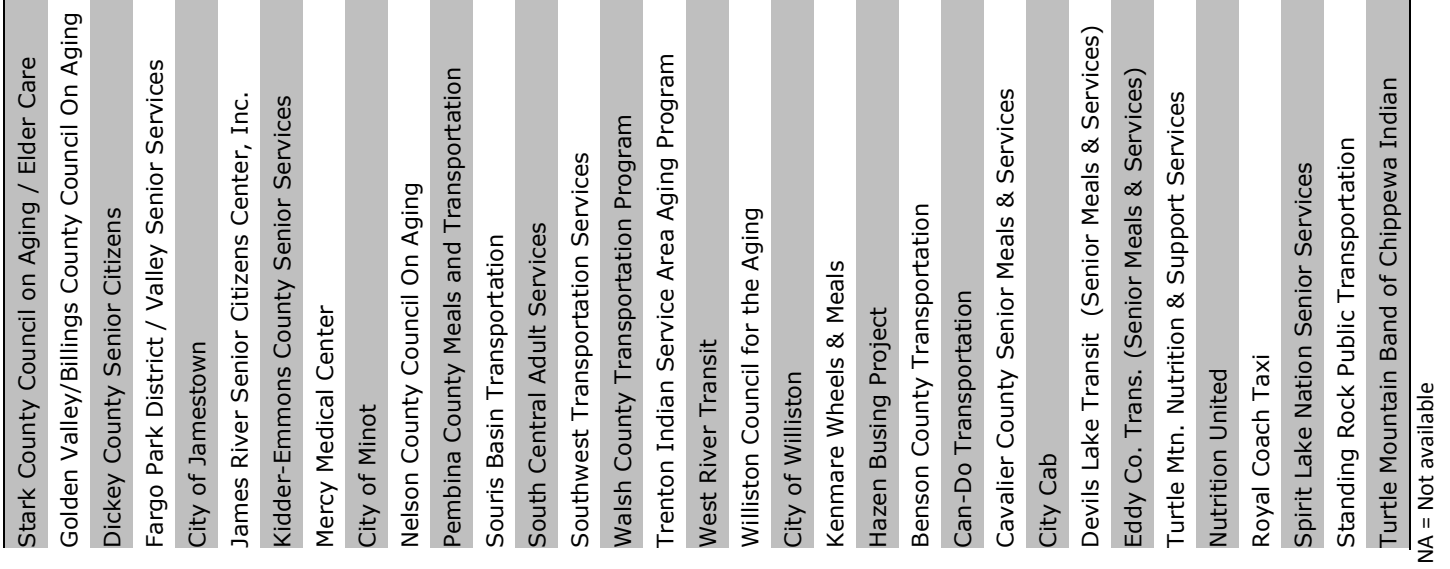




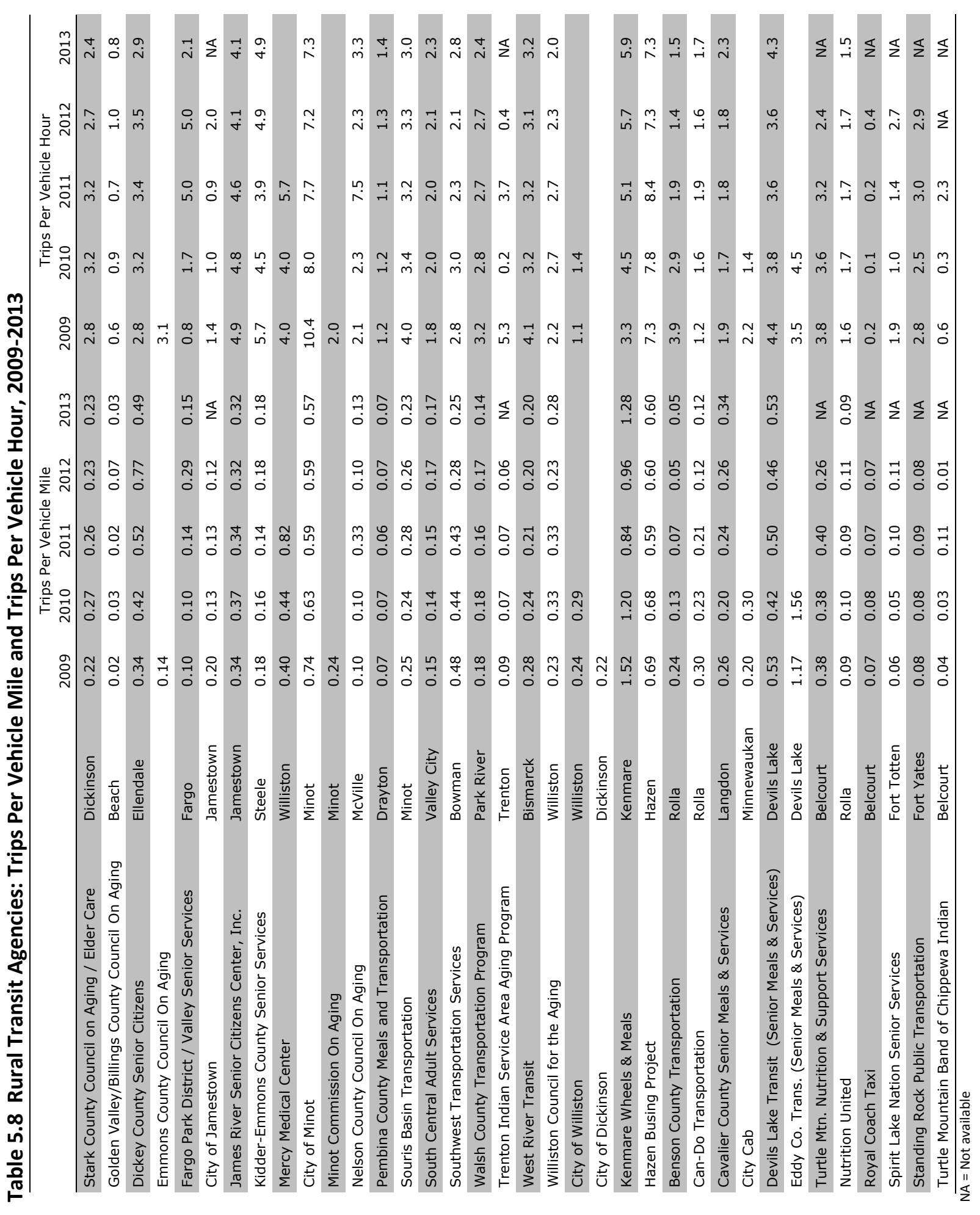




\subsection{Survey of Transit Providers}

\subsubsection{Types of Service Provided}

Four transit agencies in the state provide traditional fixed-route services, the three urban systems previously mentioned - MATBUS in the cities of Fargo and West Fargo, Cities Area Transit in Grand Forks, and Bis-Man Transit in Bismarck and Mandan - and Minot City Transit. The remaining agencies throughout the state provide a type of demand-response service, and some provide a flexible-route or intercity service. Nearly all of the rural agencies provide demand-response service for the general public, and some provide human service transportation for clients of human service programs (Table 5.9).

Most of the demand-response systems provide door-to-door service, which is a higher quality service than curb-to-curb, but none reported providing a door-through-door service, which is a higher-quality service where drivers help riders in and out of buildings (Table 5.10). While MATBUS in Fargo does not technically provide door-through-door service, it does provide door-through-first-door service, where drivers can provide assistance through the first door, such as into the lobby of a building. Bis-Man Transit also provides some of this type of service. All of the transit operators provide service for the general public, as well as for senior citizens and people with disabilities.

Table 5.9 What type of transportation services does your organization provide (check all that apply)?

\begin{tabular}{lcc}
\hline Service Type & $\begin{array}{c}\text { Number of } \\
\text { Agencies }\end{array}$ & $\begin{array}{c}\text { Percentage } \\
\text { of Agencies }\end{array}$ \\
\hline Traditional fixed-route & 4 & $15 \%$ \\
Flexible route & 5 & $19 \%$ \\
Demand-response for the general public & 23 & $85 \%$ \\
Limited-eligibility demand-response (serving only certain rider groups) & 1 & $4 \%$ \\
Human service transportation (for clients of human service programs) & 11 & $41 \%$ \\
Veterans transportation & 10 & $37 \%$ \\
\hline
\end{tabular}

Table 5.10 Do you provide the following types of service (check all that apply)?

\begin{tabular}{lcc}
\hline Service Type & $\begin{array}{c}\text { Number of } \\
\text { Agencies }\end{array}$ & $\begin{array}{c}\text { Percentage } \\
\text { of Agencies }\end{array}$ \\
\hline Fixed-route & 4 & $15 \%$ \\
Curb-to-curb & 9 & $35 \%$ \\
Door-to-door & 21 & $81 \%$ \\
Door-through-door or escort service & 0 & $0 \%$ \\
\hline
\end{tabular}




\subsubsection{Span of Service}

Service span measures the days per week and hours per day that service is available in a particular area. It is one of the measures of demand-response quality of service used in the Transit Capacity and Quality of Service Manual (TCQSM) (Kittelson \& Associates et al. 2013). The survey collected information on the number of days per week transit agencies provide service in different areas, as well as the number of hours per service day. The results are mapped in Figures 5.1 and 5.2.

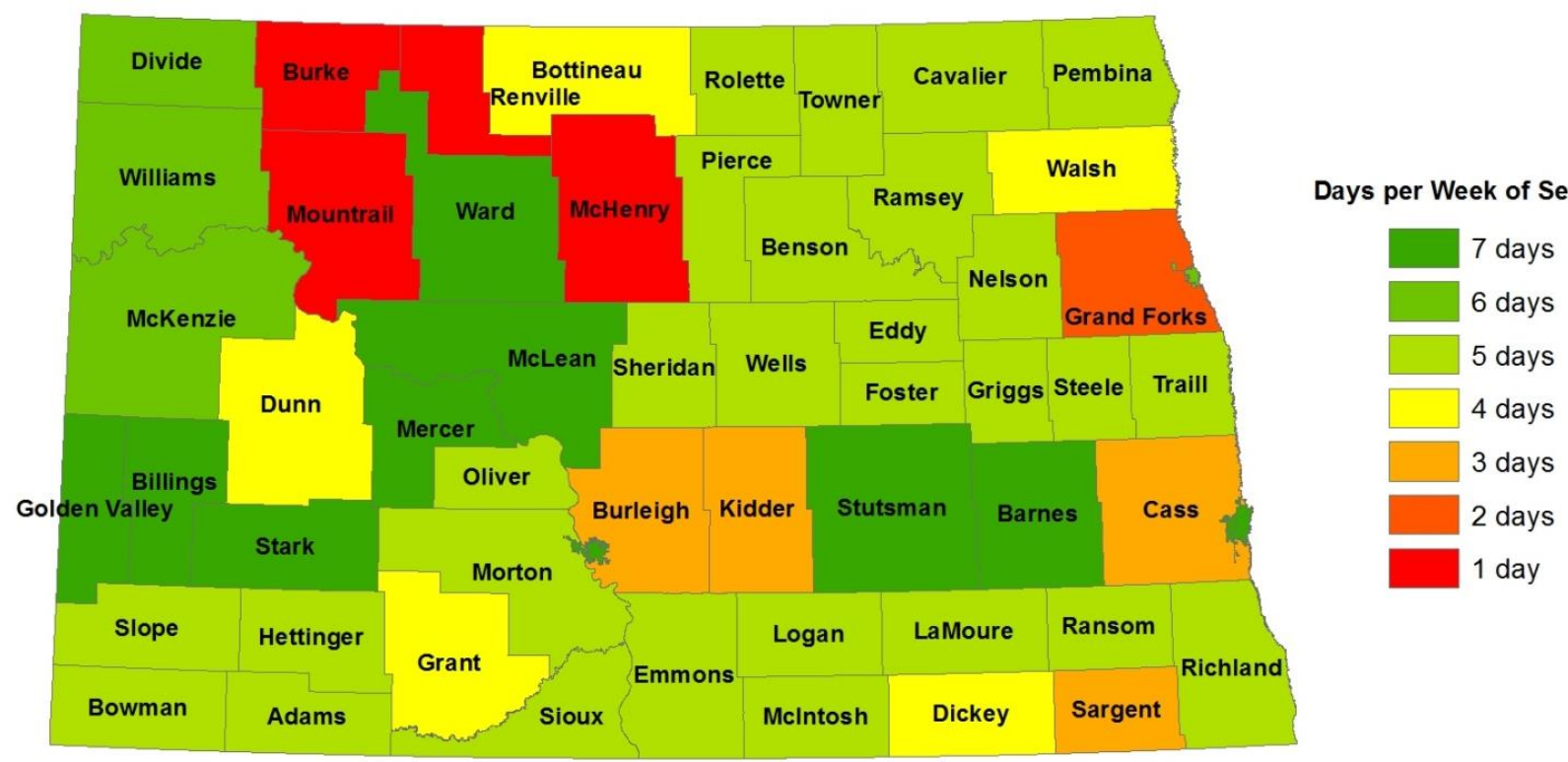

\section{Figure 5.1 Days per Week of Transit Service}

Note: Days of service may be greater in some areas where coordination exists between transit agencies.

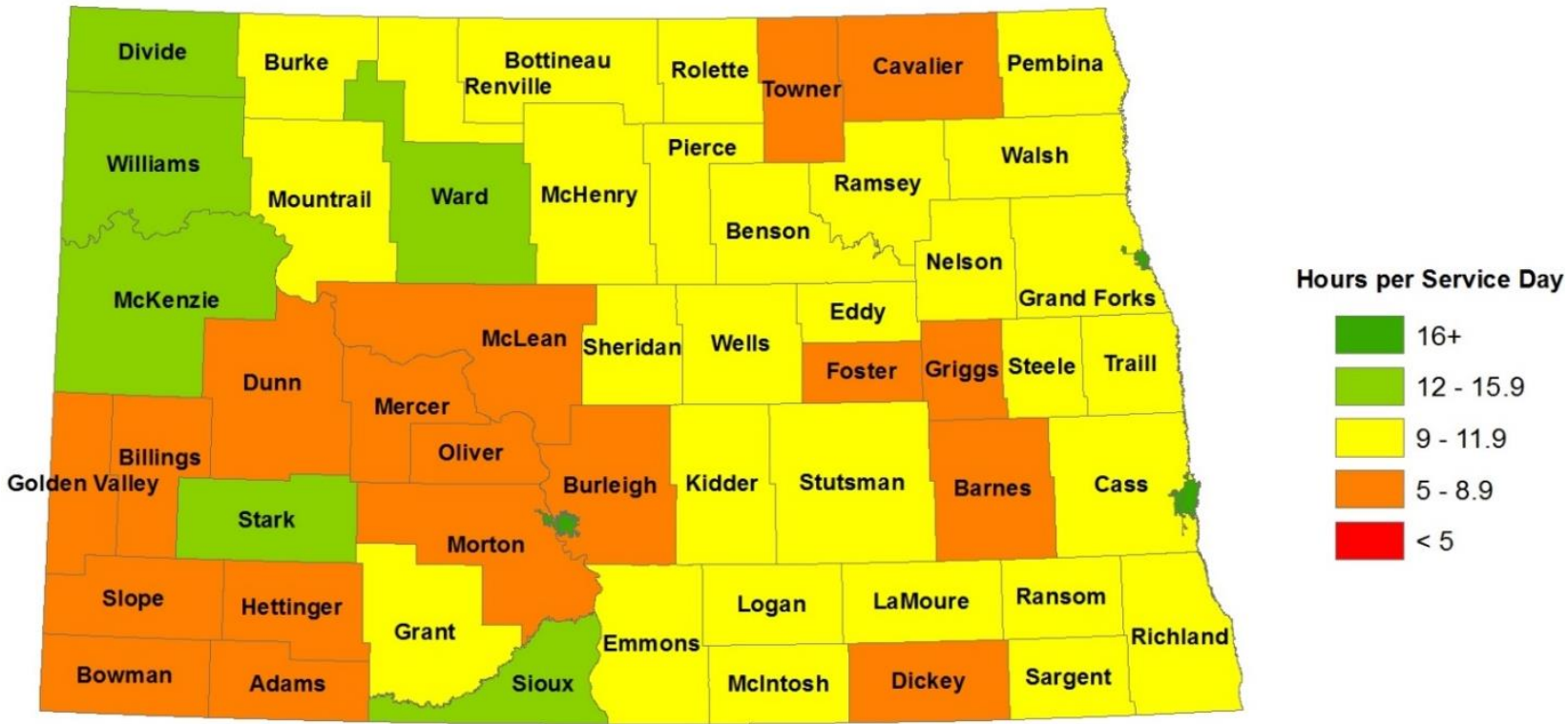

Figure 5.2 Hours per Service Day 
While everyday service exists in some parts of the state, much of the state has service five days per week. Some areas have service just one day per week, while a few areas have service two or three days per week. Fixed-route services in Fargo-West Fargo, Bismarck-Mandan, and Grand Forks operate six days per week, while the complementary paratransit is available seven days per week in Fargo-West Fargo and Bismarck-Mandan and six days per week in Grand Forks. Dickinson Public Transit provides service seven days per week in Stark County, but trips outside the city of Dickinson are limited depending on driver availability.

Figure 5.1 may underestimate days of service in some areas where coordination exists between transit agencies. This figure shows service provided by the primary agency serving the county or urban area, but coordination between neighboring agencies can result in greater levels of service. For example, coordination between Souris Basin Transportation and Northwest Dakota Transit results in higher levels of service in some areas, such as Mountrail County.

Rural transit agencies commonly provide service 8-10 hours per day, while a few areas have a more limited service. Urban transit agencies provide 16 or more hours per day, and Dickinson Public Transit provides about 15 hours per day.

The TCQSM second edition ${ }^{1}$ devised a measure of demand-response transit level of service based on days and hours of service, as shown in Table 5.11 (Kittelson \& Associates et al. 2003). The lower number indicates a higher level of service, with LOS 1 being the highest level of service. Based on this framework, level of service was calculated and mapped across the state (Figure 5.3).

Table 5.11 Framework for Measuring Service Span Level of Service

\begin{tabular}{cccccccc}
\hline $\begin{array}{c}\text { Hours Per } \\
\text { Day }\end{array}$ & $6-7$ & 5 & $3-4$ & 2 & 1 & 0.5 & $<0.5$ \\
\hline$\geq 16.0$ & LOS 1 & LOS 2 & LOS 4 & LOS 5 & LOS 6 & LOS 7 & LOS 8 \\
$12.0-15.9$ & LOS 2 & LOS 3 & LOS 4 & LOS 5 & LOS 6 & LOS 7 & LOS 8 \\
$9.0-11.9$ & LOS 3 & LOS 4 & LOS 4 & LOS 6 & LOS 6 & LOS 7 & LOS 8 \\
$5.0-8.9$ & LOS 5 & LOS 5 & LOS 5 & LOS 6 & LOS 7 & LOS 7 & LOS 8 \\
$<5$ & LOS 6 & LOS 6 & LOS 6 & LOS 7 & LOS 7 & LOS 8 & LOS 8 \\
\hline
\end{tabular}

\footnotetext{
${ }^{1}$ The TCQSM second edition uses " $<4$ hours" as the lowest level for hours of service, but this was revised to " $<5$ hours" in the third edition, which is what is used in this study. The TCQSM third edition no longer combines days and hours of service into a single level of service measure.
} 


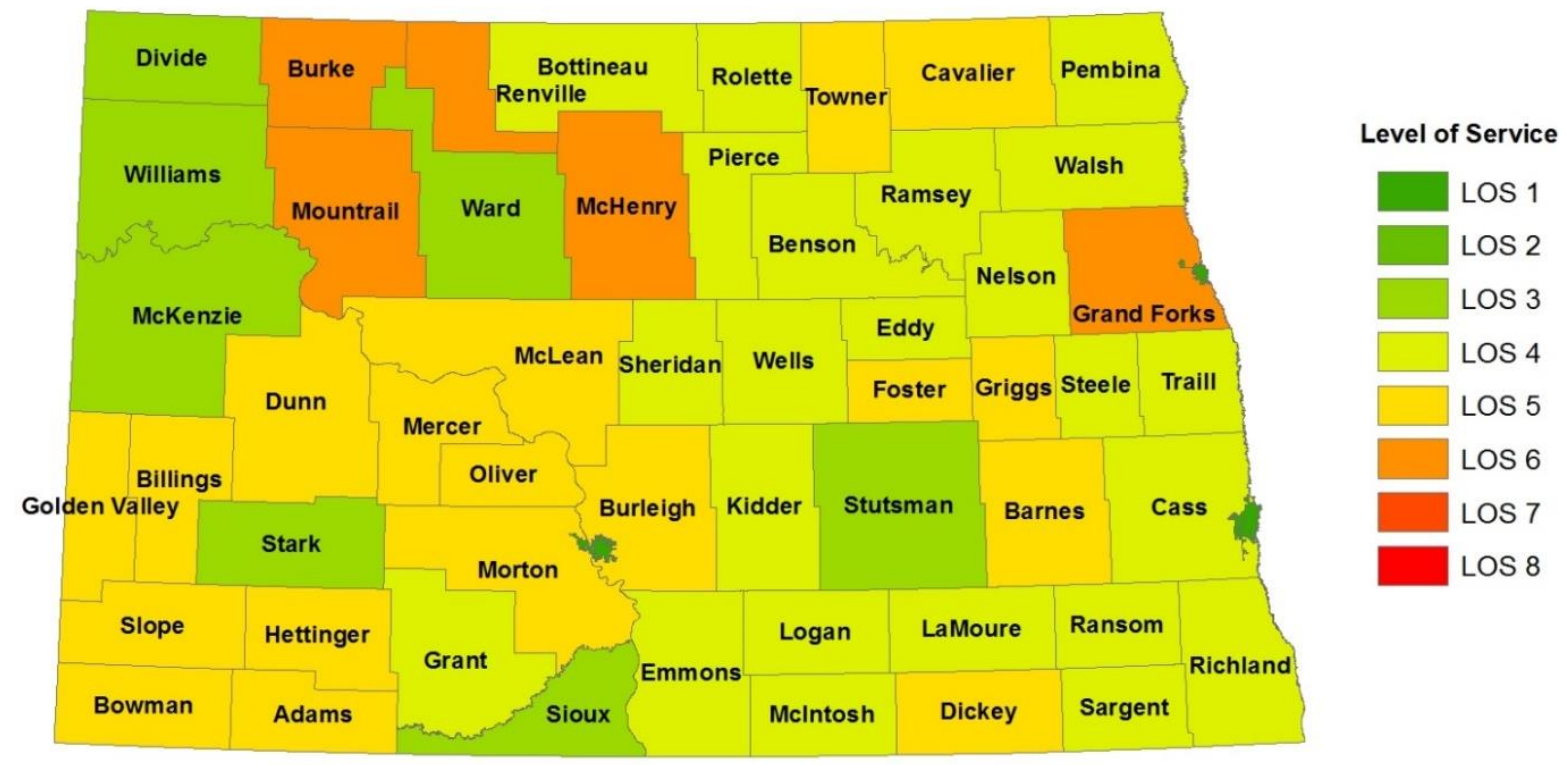

Figure 5.3 Public Transit Level of Service

Level of service is highest in the urban areas of Fargo, Bismarck, and Grand Forks. Stark, Stutsman, Ward, and the northwestern counties have the next highest level of service. Minot and Kenmare have good levels of service, in terms of days and hours, but the rest of Ward County has lower levels of service. Similarly, Valley City, Lisbon, Wahpeton, Devils Lake, Grafton, Bottineau, Williston, and Watford City have service usually five days per week, but the rural areas of their counties have lower levels of service.

While this measure of level of service provides useful information about availability of service, measured in terms of days per week and hours per day of service, other measures of level of service, such as the availability of vehicles, response time, and vehicle miles of service provided, are not included. These factors will be evaluated in later sections.

\subsubsection{ADA Complementary Paratransit}

The Americans with Disabilities Act (ADA) requires agencies operating fixed-route service to provide complementary paratransit for those not able to use fixed-route service. Generally, it must operate in the same areas and during the same hours as fixed-route transportation. The ADA requires that complementary paratransit be provided within $3 / 4$ mile of all fixed-routes, but transit agencies may provide a higher level of service that goes beyond this requirement, which is the case in North Dakota. Cities Area Transit, the Bis-Man Transit Board, and MATBUS provide complementary paratransit within city limits in Grand Forks, Bismarck, Mandan, Fargo, and West Fargo. Souris Basin Transportation provides complementary paratransit service throughout the city of Minot.

Span of service is also greater for the complementary paratransit in some cities. The Bis-Man Paratransit service runs 24/7. MATBUS provides paratransit service seven days a week in Fargo and West Fargo, 
while the fixed-route service runs six days a week in those cities. In Minot, the fixed-route service runs five days a week, while the paratransit service is available seven days a week.

\subsubsection{Advance Reservation Time}

Response time, or advance reservation time, is an important measure of transit availability. Allowing riders to schedule trips with shorter advance notice increases the availability of the service to the user. The TCQSM includes reservation time as a measure of demand-response transit quality of service. Transit agencies were asked to identify their minimum advance reservation time for demand-response or complementary paratransit service, using categories from the TCQSM second edition.

As shown in Table 5.12, transit agencies commonly require reservations to be made 24 hours in advance, or during the previous service day, but more than half allow for reservations to be made the same day as the trip, including nine agencies that provide trips within one half hour of making the reservation. Some operators will provide this high-quality service for in-town trips but require more advanced notice for out-of-town trips. For example, Cavalier County Transit, Southwest Public Transit, and South Central Adult Service allow in-town trips to be made with a half hour reservation time, but out-of-town trips need to be scheduled the previous service day. No agencies require trips to be scheduled more than one day in advance.

Table 5.12 What is the minimum advance reservation time for your agency operating demandresponse or complementary paratransit?

\begin{tabular}{lcc}
\hline Minimum Advance Reservation Time & $\begin{array}{c}\text { Number of } \\
\text { Agencies }\end{array}$ & $\begin{array}{c}\text { Percentage } \\
\text { of Agencies }\end{array}$ \\
\hline Up to 1/2 hour & 9 & $35 \%$ \\
More than 1/2 hour and up to 2 hours & 3 & $12 \%$ \\
More than 2 hours, but still same day & 3 & $12 \%$ \\
24 hours in advance, or prior service day & 11 & $42 \%$ \\
48 hours, or 2 days, in advance & 0 & $0 \%$ \\
More than 48 hours in advance, and up to 1 week & 0 & $0 \%$ \\
More than 1 week in advance, and up to 2 weeks & 0 & $0 \%$ \\
More than 2 weeks & 0 & $0 \%$ \\
\hline
\end{tabular}

\subsubsection{Fares}

Information on fares was collected for fixed-route and demand-response providers for both in-town and longer-distance trips. Data for demand-response fares are shown in Table 5.13. Many rural transit agencies charge a round-trip fare. These fares were divided by two to calculate a one-way fare. All demand-response providers charge the same rate for senior citizens, youth, and the general public. Public transit in Dickinson provides two different types of service, scheduled trips and on-demand taxi service, and charges different fares for each. It charges $\$ 4$ one way for a scheduled trip and $\$ 8$ one way 
for their on-demand taxi service for in-town trips, and for out-of-town trips, it adds $\$ 1$ per mile to the fare. Fares charged by the fixed-route systems are shown in Table 5.14.

Table 5.13 One-Way Fares Charged by Demand-Response Transit Providers

\begin{tabular}{lrrrr}
\hline One-way trip distance & Average & Median & Minimum & Maximum \\
\hline In-town & 2.16 & 1.50 & 0.00 & 13.00 \\
Out-of-town up to 15 miles & 3.98 & 2.75 & 0.00 & 15.00 \\
16-30 miles & 4.88 & 3.00 & 1.50 & 26.50 \\
$31-45$ miles & 5.84 & 3.75 & 2.00 & 25.00 \\
$46-60$ miles & 7.10 & 5.00 & 2.50 & 25.00 \\
$61-75$ miles & 6.71 & 5.00 & 3.50 & 12.00 \\
76-100 miles & 12.04 & 7.25 & 3.50 & 37.50 \\
More than 100 miles & 17.70 & 12.50 & 3.50 & 65.00 \\
\hline
\end{tabular}

Table 5.14 Fares Charged by Fixed-Route Transit Providers

\begin{tabular}{|c|c|c|c|c|}
\hline & & Cash Faı & & \\
\hline & & & Senior & \\
\hline & Youth & Adult & Citizen & Notes \\
\hline $\begin{array}{l}\text { Grand } \\
\text { Forks: } \\
\text { Cities Area } \\
\text { Transit }\end{array}$ & 0.75 & 1.50 & 0.60 & $\begin{array}{l}\text { Disabled riders pay } \$ 0.60 \text { cash fare. Reduced prices for } 10 \text {-ride } \\
\text { tickets: Adults } \$ 13.00, \mathrm{~K}-12 \text { Students } \$ 6.50 \text {, Seniors (age } 62+\text { ) } \\
\$ 5.25 \text {, Medicare card holders and disabled card holders } \$ 5.25 \text {. } \\
\text { unlimited ride } 1 \text {-day pass: } \$ 5.00 ; \text { unlimited ride } 14 \text {-day pass: } \\
\$ 18.00 ; \text { unlimited ride } 31-\text { day pass: } \$ 35.00\end{array}$ \\
\hline $\begin{array}{l}\text { Fargo: } \\
\text { Metro Area } \\
\text { Transit }\end{array}$ & 0.75 & 1.50 & 0.75 & $\begin{array}{l}\text { Preschool children free with an adult. 1-day, 14-day, and 30-day } \\
\text { passes are available, as well as 10-ride tickets. University } \\
\text { students and staff have free fare through the U-Pass program. }\end{array}$ \\
\hline $\begin{array}{l}\text { Bismarck: } \\
\text { Bis-Man } \\
\text { Transit }\end{array}$ & 0.50 & 1.25 & 0.50 & $\begin{array}{l}\text { Cash fare is also } \$ 0.50 \text { for individuals with disabilities and } \\
\text { Medicare card holders. Adults can purchase a } 1 \text {-day pass for } \$ 5 \\
\text { and a } 30 \text {-day pass for } \$ 30 \text {. Reduced rate groups (students, } \\
\text { seniors age } 60+\text {, individuals with disabilities, and Medicare card } \\
\text { holders) can purchase a } 1 \text {-day pass for } \$ 2.50 \text {, and a } 30 \text {-day pass } \\
\text { for } \$ 20 \text {. }\end{array}$ \\
\hline $\begin{array}{l}\text { Minot: } \\
\text { City Transit }\end{array}$ & 1.25 & 1.25 & 1.25 & $\begin{array}{l}\text { Packs of } 10 \text { adult tokens for } \$ 10.00 ; \text { monthly adult passes for } \\
\$ 34.00 ; \text { packs of } 10 \text { student, senior, or disabled tokens for } \\
\$ 8.00 ; \text { monthly student, senior, or disabled pass for } \$ 26.00\end{array}$ \\
\hline
\end{tabular}




\subsubsection{Rider Characteristics}

Transit agencies were asked to identify, if known, the percentage of riders that are senior citizens (age 60 or older), people with disabilities, or youth (up to age 18). As shown in Table 5.15, a high percentage of the riders are older adults and people with disabilities. Some systems also provide a higher number of trips to students.

Table 5.15 Percentage of Riders that are Older Adults, People with Disabilities, or Youth

\begin{tabular}{|c|c|c|c|}
\hline & $\begin{array}{l}\text { Elderly (age } \\
60 \text { or older) }\end{array}$ & $\begin{array}{l}\text { People with } \\
\text { Disabilities }\end{array}$ & $\begin{array}{l}\text { Youth (up to } \\
\text { age 18) }\end{array}$ \\
\hline & \multicolumn{3}{|c|}{----------percentage of riders----------- } \\
\hline \multicolumn{4}{|l|}{ Fixed-Route Systems } \\
\hline Bismarck & NA & NA & NA \\
\hline Grand Forks & 6.5 & 6.4 & 3.2 \\
\hline Fargo & 4 & 14 & 2 \\
\hline Minot & 15 & & 57 \\
\hline \multicolumn{4}{|l|}{ Demand-Response Systems } \\
\hline Benson County Transportation & 90 & 0.75 & 0.25 \\
\hline Bis-Man Transit & NA & NA & NA \\
\hline Cavalier County Transit & 85 & 10 & 5 \\
\hline Dickey County Transportation & 82 & 7 & 1 \\
\hline Dickinson Public Transit (Eldercare) & 19 & 19 & 2 \\
\hline Fargo: Metro Area Transit & & 100 & \\
\hline Glen Ullin Transportation & 90 & 9 & 1 \\
\hline Grand Forks: Cities Area Transit & 37 & 62.9 & \\
\hline Handi-Wheels Transportation & 30 & 61 & 9 \\
\hline Hazen Transit/City of Hazen & 20 & 2 & 78 \\
\hline James River Senior Citizens & 50 & 40 & 10 \\
\hline Kenmare Wheels \& Meals & 35 & 15 & 5 \\
\hline Nelson County Transit & 55 & 30 & 15 \\
\hline Northwest Dakota Public Transit & 30 & 25 & 20 \\
\hline $\begin{array}{l}\text { Pembina County Meals \& Transportation } \\
\text { Senior Meals \& Services Inc. (Devils }\end{array}$ & NA & NA & NA \\
\hline Lake/Eddy County Transit) & 22 & 24 & 1 \\
\hline Souris Basin Transportation & 45 & 30 & 2 \\
\hline South Central Adult Services & 37 & 9 & 54 \\
\hline Southwest Public Transit & 65 & 9 & $1-3$ \\
\hline Standing Rock Public Transit & 9 & 0 & 4 \\
\hline Valley Senior Services & 65 & 10 & 3 \\
\hline Walsh County Transportation & 70 & 15 & 15 \\
\hline West River Transit & 76 & 3 & 21 \\
\hline Wildrose Public Transportation & 95 & & 1 \\
\hline
\end{tabular}

NA = Not Available 


\subsubsection{Trip Purposes}

Transit agencies across the state provide trips for a number of purposes, with the largest shares being for medical trips, followed by shopping and work trips (Table 5.16). The average transit agency in the state provides about $40 \%$ of its trips for medical purposes, $20 \%$ for shopping, and $15 \%$ for employment trips, but as shown in Table 5.16, some provide a much higher percentage of their trips for particular purposes. (Note: The percentages reported in Table 5.16 are un-weighted averages of all transit agencies responding to the survey.)

Table 5.16 Transit Trip Purposes

\begin{tabular}{lcccc}
\hline \multirow{2}{*}{ Trip Purpose } & \multicolumn{5}{c}{ Percentage of Trips Reported by Transit Agencies } \\
\hline Employment & Average & Median & Minimum & Maximum \\
Education/job training & 15 & 12 & 0 & 53 \\
Medical (including dialysis) & 8 & 3 & 0 & 55 \\
Dialysis & 40 & 38 & 10 & 90 \\
Nutrition & 5 & 4 & 0 & 30 \\
Shopping & 7 & 5 & 0 & 30 \\
Social/recreation & 21 & 17 & 0 & 65 \\
Other & 6 & 6 & 0 & 10 \\
\hline
\end{tabular}




\section{MOBILITY GOALS AND GAPS AND TRANSIT NEEDS}

\subsection{Transit Agency Needs}

The transit agency survey collected information regarding needed facility upgrades, the capacity for transit agencies to meet service requests, need for new services, and staffing needs. The survey of human service agencies also collected information regarding the need for new services to meet the demands of their clients.

\subsubsection{Facilities}

Most rural transit systems outsource maintenance and do not own any maintenance facilities. The agencies either own or rent garage space for vehicle storage, though some vehicles are stored outside. Some providers own office space for administrative purposes, while others rent or share office space, and a few do not have office space or use the home of a staff member for administrative purposes. A more detailed description of existing facilities is shown with the transit agency information in Appendix F.

Transit agencies were asked to describe the adequacy of their facilities for meeting current and expected future needs (within the next five years). Responses are shown in Figure 6.1. Nine agencies indicated that vehicle storage facilities are inadequate for current needs, and another seven answered that their facilities, while currently adequate, are inadequate for expected future needs. Many agencies indicated that administrative facilities are inadequate for expected future needs, while three said they are currently inadequate. Maintenance facilities are currently inadequate for three providers and are inadequate for the expected future needs of seven additional transit operators. Some agencies also mentioned the need for upgraded passenger facilities, which can include transfer hubs, passenger stations, or other facilities. Minot City Transit mentioned a need for a downtown fixed-route transfer facility, and the city of Fargo noted a need for more space to handle a large number of passengers and expanded capacity for transferring vehicles. Detailed responses regarding needed facility upgrades are presented in Table 6.1. 


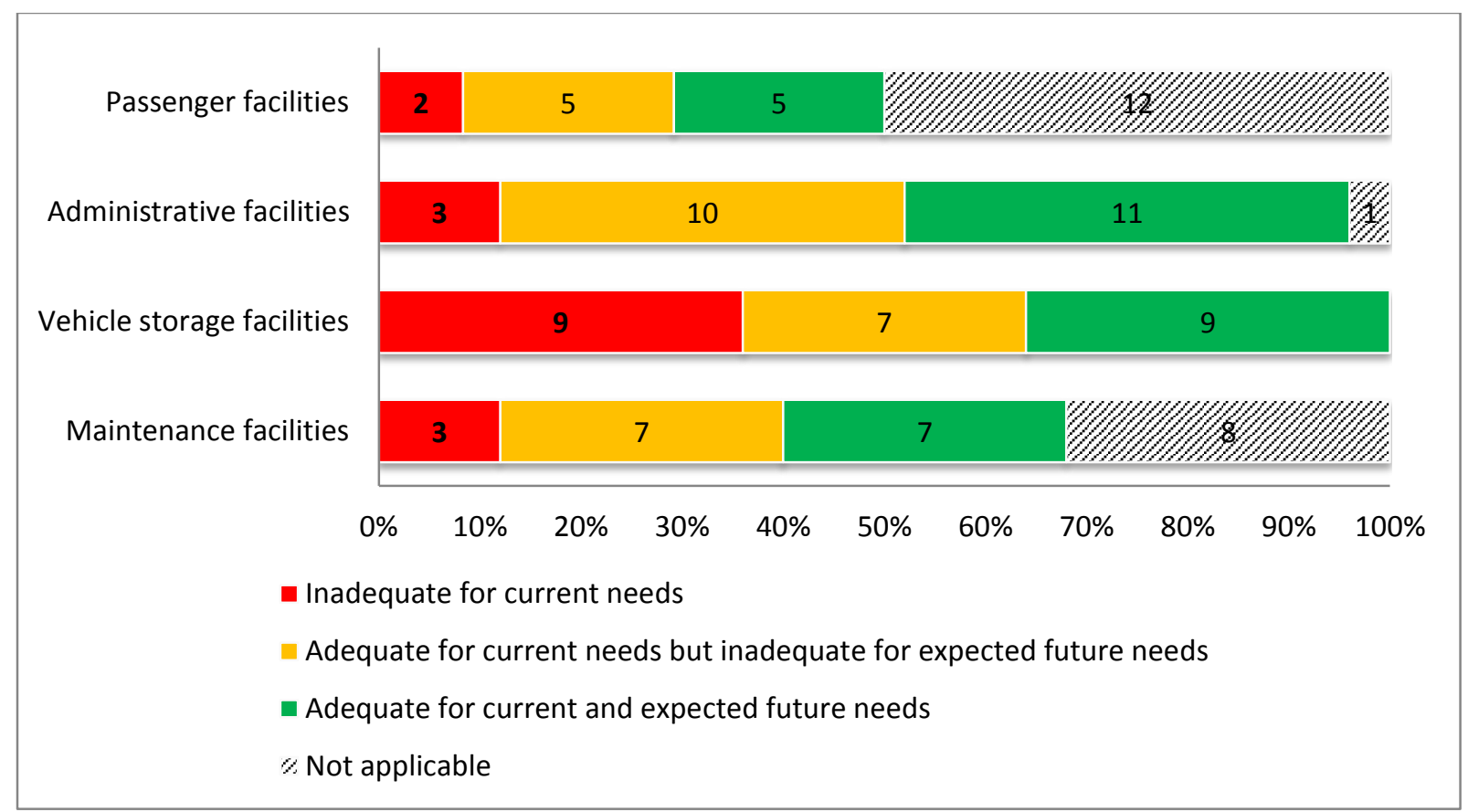

Figure 6.1 Adequacy of Facilities for Needs 
Table 6.1 Needed Facility Upgrades

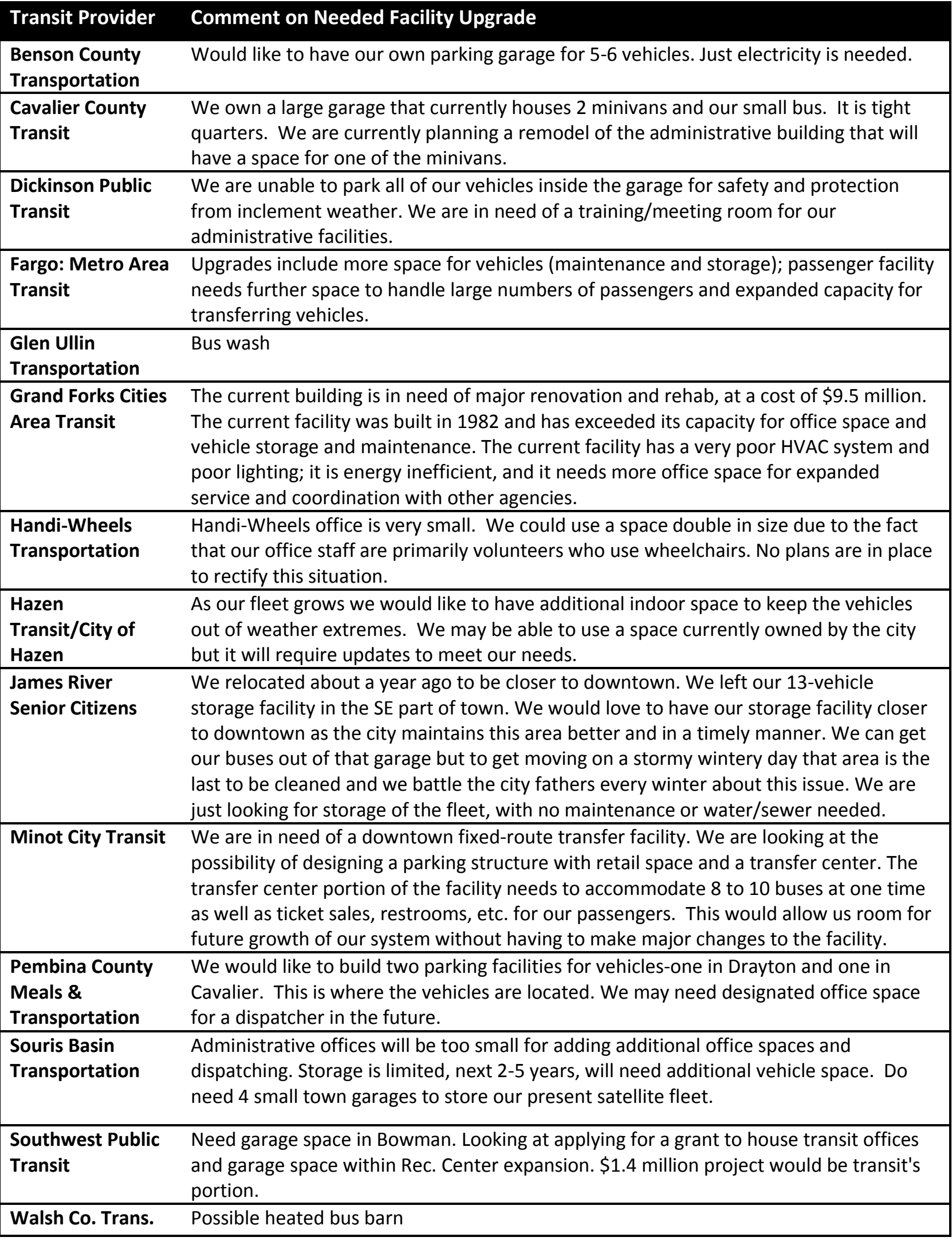


The facility upgrades detailed in Table 6.1 are those identified by the transit agencies. This study does not provide cost estimates for facility needs, and prioritizing these projects is beyond the scope of this study. The NDDOT may need to provide guidelines or guidance to transit agencies regarding vehicle storage or maintenance facilities to help identify which projects are most likely to be funded.

\subsubsection{Capacity to Serve Demand}

Transit providers may sometimes have to turn down riders' trip requests if there is not enough capacity at the riders' requested time. Capacity refers to the space availability on vehicles and the time available on the vehicles' schedules. If capacity is not available at the requested time, the transit provider may try to identify a different time for the trip, but if the rider cannot adjust the trip time, then the trip is turned down and the rider is unable to use the service. If riders are unable to schedule a trip when they wish to travel, then the service will be considered less reliable.

Most demand-response providers will occasionally have to turn down a trip during periods of unusual demand, when they are unexpectedly short on drivers, or because of some other atypical event. If trip turn downs become more frequent, it indicates insufficient capacity to meet the demand. This problem could be addressed by adjusting driver schedules to provide more capacity during periods of greatest need, or it may require adding more vehicles, drivers, or service hours.

The TCQSM third edition measures quality of service using the following levels for percentage of trips turned down: $0-1 \%,>1-3 \%,>3-5 \%,>5-10 \%$, and $>10 \%$. The survey collected information from demandresponse providers regarding how often they have to turn down trips because of lack of capacity, as shown in Table 6.2. For most agencies, trip turn downs are rare. Fourteen of the 22 responding agencies reported turning down $0-1 \%$ of trips, and three providers turn down $1-3 \%$ of trips.

Table 6.2 Percentage of Demand-Response Transit Trip Requests Turned Down Because of Lack of Capacity

\begin{tabular}{lcc}
\hline Trips Turned Down & $\begin{array}{c}\text { Number of } \\
\text { Agencies }\end{array}$ & $\begin{array}{c}\text { Percentage } \\
\text { of Agencies }\end{array}$ \\
\hline $0-1 \%$ & 14 & $64 \%$ \\
$1-3 \%$ & 3 & $14 \%$ \\
$3-5 \%$ & 1 & $5 \%$ \\
$5-10 \%$ & 1 & $5 \%$ \\
More than 10\% & 2 & $9 \%$ \\
Don't know/don't collect data & 1 & $5 \%$ \\
\hline
\end{tabular}

However, three agencies reporting turning down 5\% or more of trips requested. Handi-Wheels in FargoWest Fargo turns down 5-10\% of trip requests, and Souris Basin Transportation and Standing Rock Public Transit reported turning down more than $10 \%$ of trip requests. This high rate of trip turn downs, especially in the areas served by Souris Basin and Standing Rock Public Transit, indicates a need for increased capacity, through some combination of increased vehicles, drivers, and service hours. 
Transit agencies providing complementary paratransit and not general demand-response service were not asked to identify trip requests that are turned down because, by law, they cannot turn down trips due to lack of capacity.

\subsubsection{Need for New Services}

Survey results also suggest a need for an expansion of service. Sixteen of the 26 responding transit agencies said there are some types of transportation services needed by their service area residents that are not currently available (Figure 6.2). Nearly all of respondents from human service agencies that were surveyed said that there are types of transportation services needed by their clients that are not currently available.

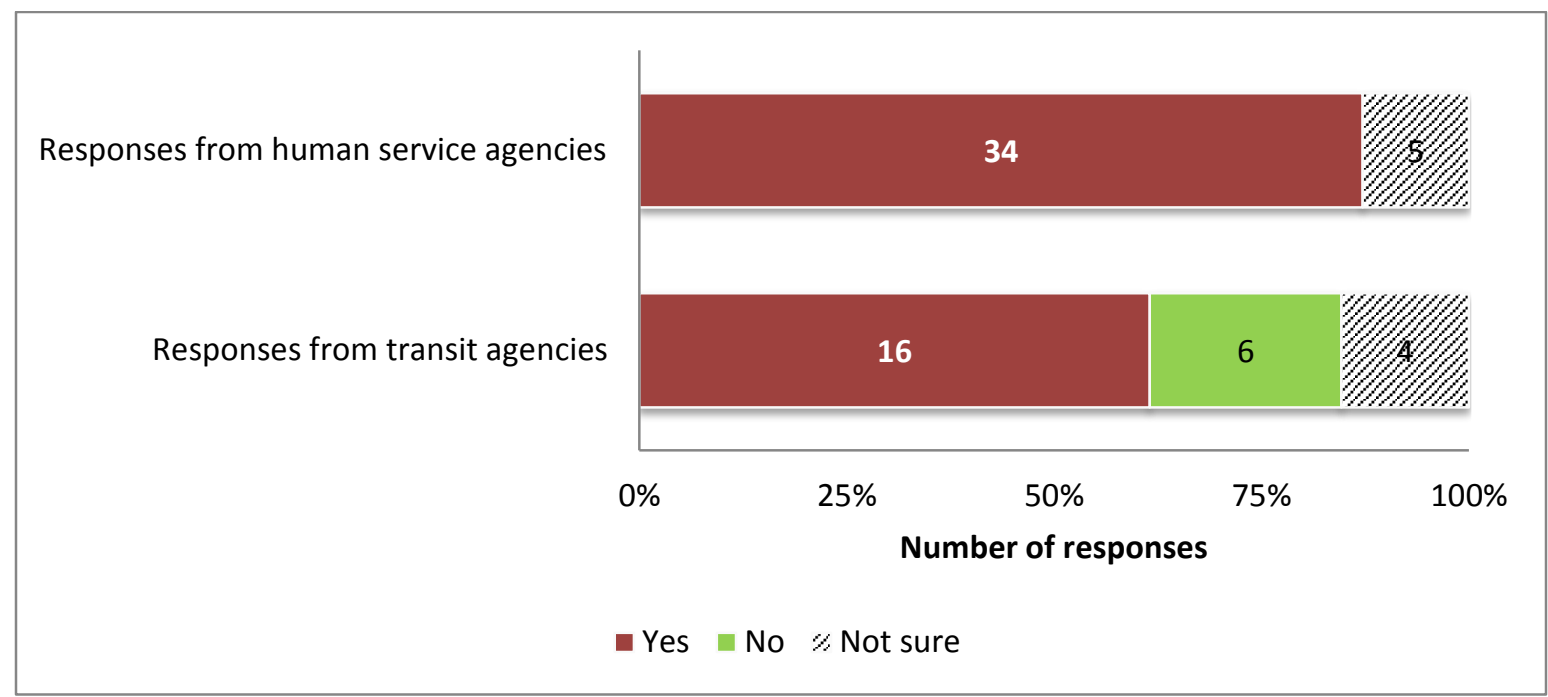

Figure 6.2 Survey results: Are there any types of transportation services needed by your clients or service area residents that are not currently available?

Respondents from both transit agencies and human service agencies most commonly mentioned a need for longer hours of service, weekend service, and an expansion of currently available services. (Figure 6.3). Six transit agencies mentioned a need for new fixed-route service, including agencies serving Fargo, Grand Forks, Minot, Dickinson, Williston, and Sioux County. Some also noted a need for new intercity service, or more out-of-town trips, as well as new door-to-door or door-though-door service. 


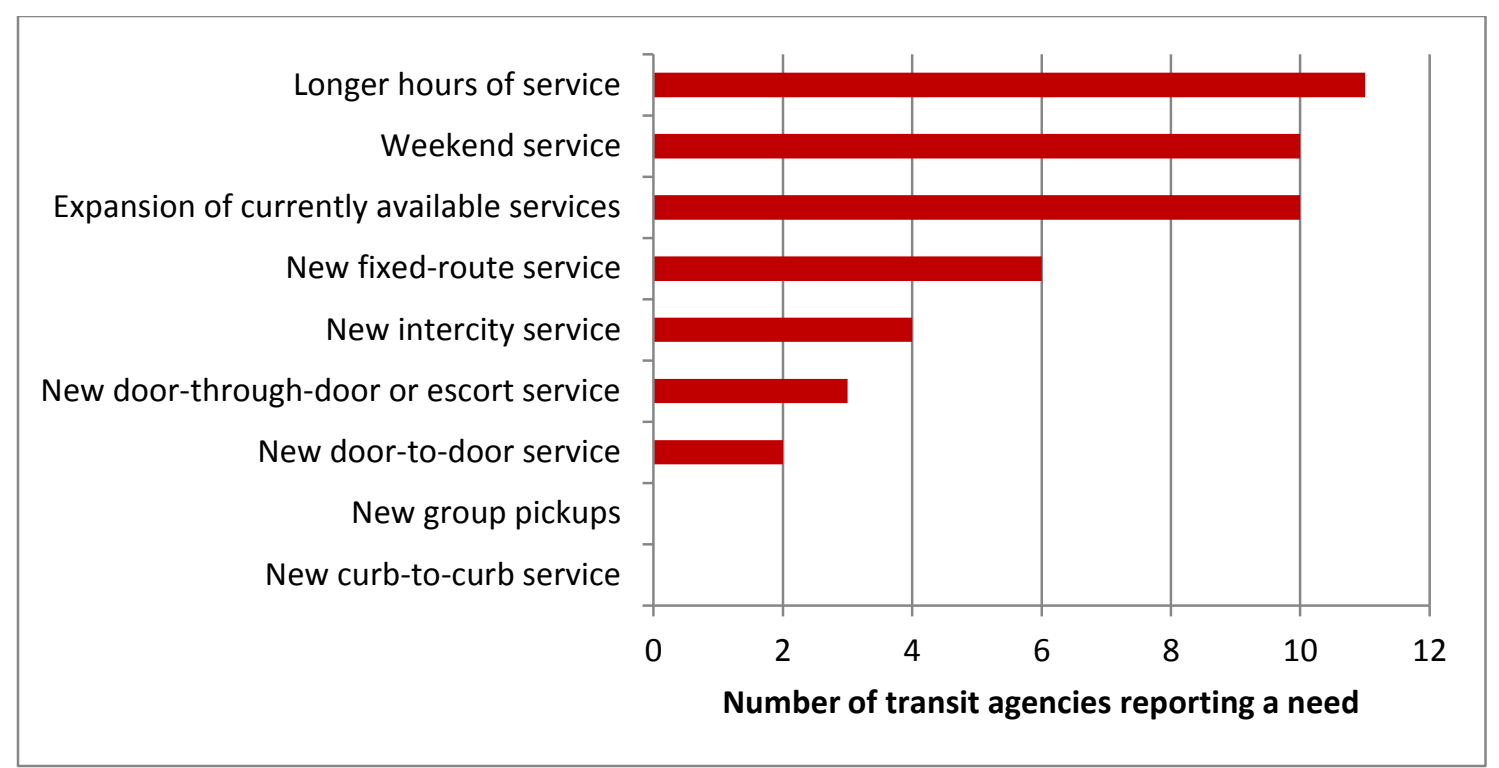

Figure 6.3 Types of Services Needed, Responses from Transit Agencies

Transit agencies and human service agencies were asked if there is a need for more transit service for specific types of trips. According to the results, the greatest needs are for medical and work trips.

Sixteen of 23 responding transit agencies indicated a need for more medical trips, including eight that listed it as a major need (Figure 6.4). Godavarthy et al. (2014) showed that providing transit trips in rural and small urban areas for medical and work purposes provides significant positive value to transportation-disadvantaged individuals and the community, with benefits outweighing the costs.

Many indicated a minor need for more service for social and recreational trips. There is also a significant need for veterans transportation services, dialysis trips, and other types of trips. A majority of respondents from human service agencies said there is a major need for more transportation service for trips for employment, as well as education/job training, medical, and social/recreation trips. Most respondents indicated at least a minor need for more transportation services (Figure 6.5). Peterson (2014) conducted an analysis on improving veteran mobility in small urban and rural areas and found that increased coordination between VA health centers and public transit providers could yield positive benefits. 


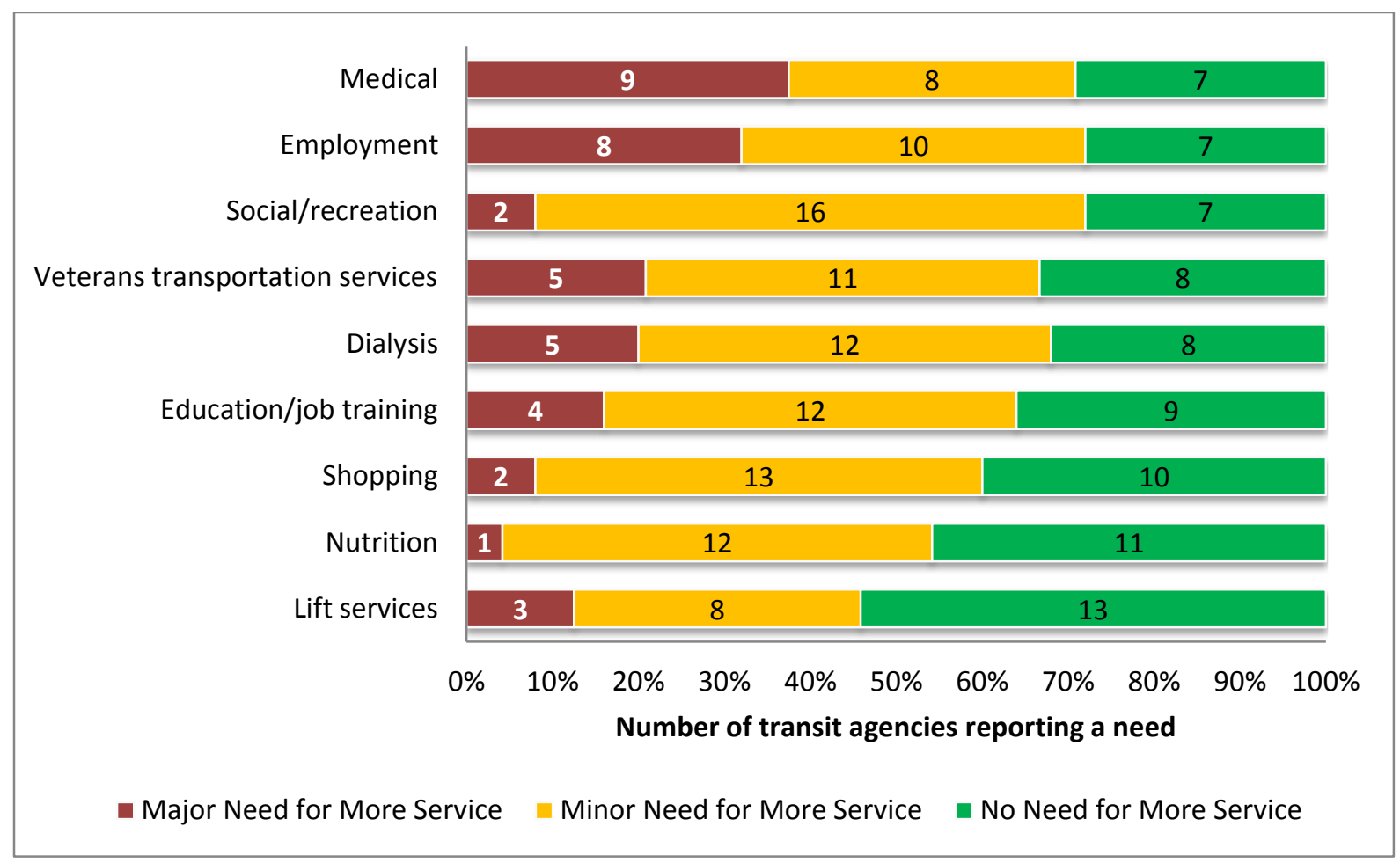

Figure 6.4 Need for More Service for Specific Types of Trips, Responses from Transit Agencies

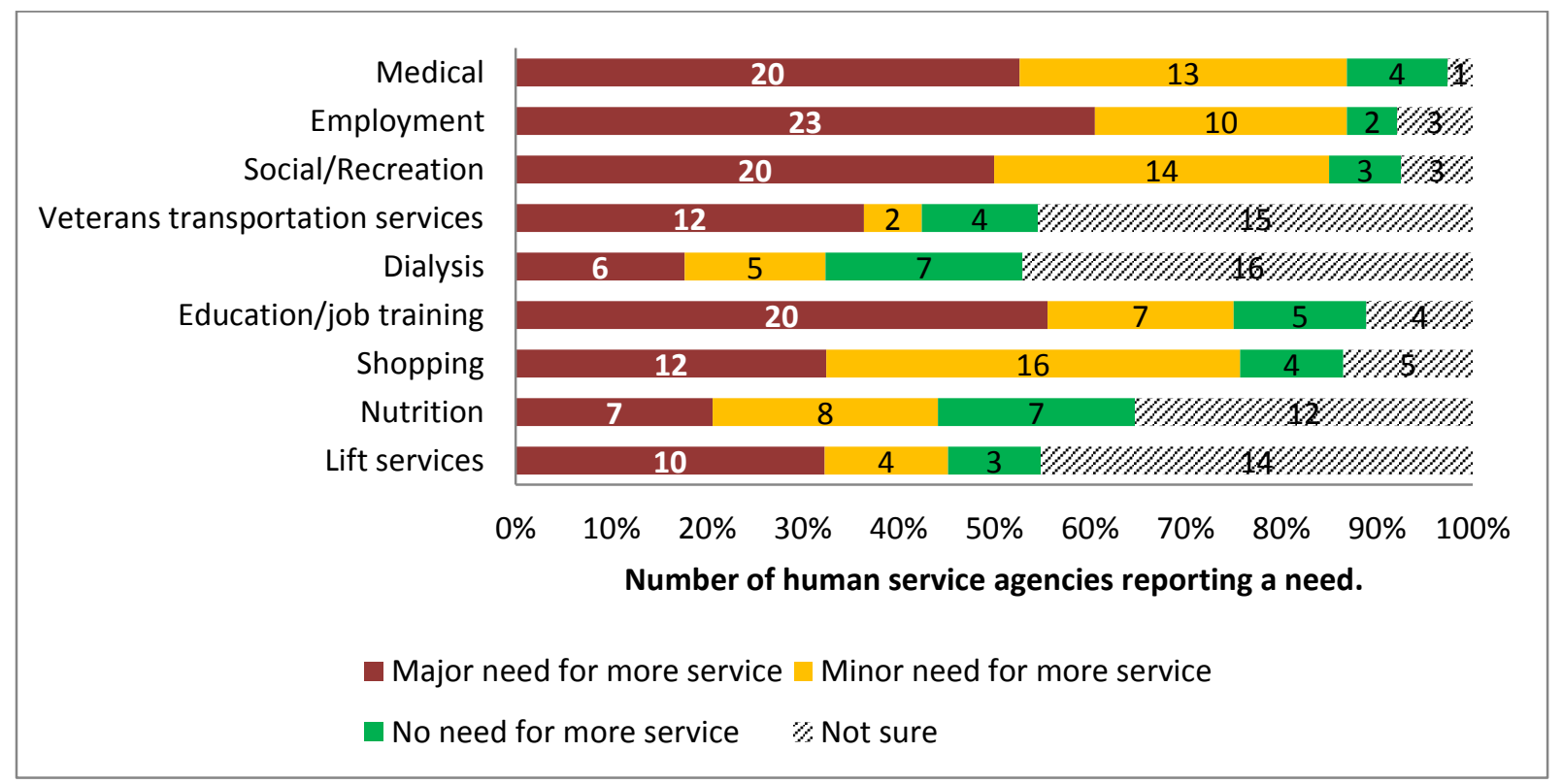

Figure 6.5 Need for More Service for Specific Types of Trips, Responses from Human Service Agencies 
Transit agencies were asked to identify the major challenge or barrier to providing additional services. Nearly all of those who responded commented that inadequate funding and staffing are the major challenges to providing the additional service. Complete responses are shown in Appendix G.

\subsubsection{Staffing Needs}

A major finding from the survey of transit agencies is the need to improve staffing capabilities. Half of the agencies (13 out of 26) indicated that they have inadequate staff to meet current needs (Figure 6.6). Of the 13 that currently have adequate staff, nine answered that they will need additional staff within the next five years to meet expected future needs. More detailed comments regarding staffing needs are presented in Appendix G.

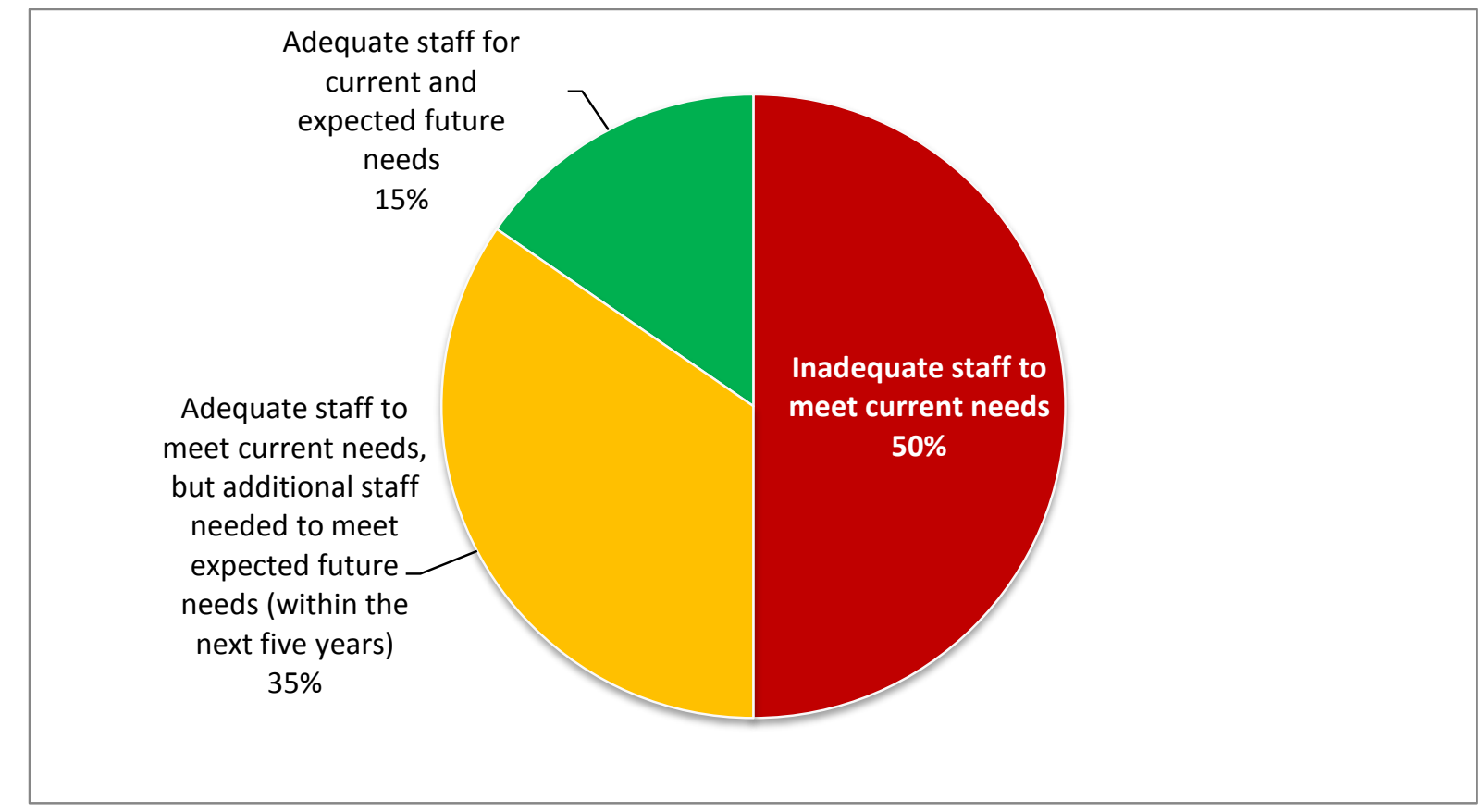

Figure 6.6 Staffing Capabilities of Transit Agencies

Many of the agencies mentioned difficulties in finding enough qualified staff. Transit agencies, especially those in the western part of the state, have to compete with the oil industry, which pays much higher wages, for qualified drivers. The Minot City Transit superintendent noted that staffing is currently the major challenge. He remarked that it is "very difficult for a municipality to compete with oil field and private companies' wages, making it difficult to hire and retain drivers." The Dickinson Public Transit director commented that it needs more office and transit staff, and "in order to hire and maintain qualified staff, we need more money for salary and benefits to attract qualified candidates." The Souris Basin Transportation director also commented on how their rural system is limited because of a lack of drivers. 
Staffing issues are not limited to the western half of the state. Respondents from eastern regions of the state also commented on staffing issues, such as many of their employees being at or near retirement age and difficulties in finding qualified bus operators. Agencies in the eastern part of the state also compete with trucking firms that offer higher wages.

Some transit providers, such as Southwest Public Transit in Bowman, recently increased wages in an effort to keep good drivers. Transit agencies statewide may need to continue increasing wages to attract and maintain a qualified staff that is of sufficient size. Such wage increases would result in increases in operating costs.

According to results from the survey, the average starting wage for transit vehicle operators in the state is $\$ 11.65$ per hour. The lowest starting wage is $\$ 8$ per hour with Handi-Wheel Transportation in Fargo, and the highest is $\$ 15.67$ with West River Transit.

\subsubsection{Overall Service}

Transit agencies were asked how well the overall transportation needs of their service area residents were being met. Most answered that their needs are being met adequately or well, though some mentioned areas needing improvement (Figure 6.7). Souris Basin Transportation, Minot City Transit, and Handi-Wheels Transportation were the three respondents that indicated that the needs of their service area residents were poorly being met. Similarly, human service agencies were asked how well the transportation needs of their clients are being met. Their responses were more negative, with most responding that the needs of their clients are being met adequately or poorly. A list of comments from transit agencies explaining their response is presented in Appendix $G$, while a list of comments from human service agencies is presented in Appendix $D$.

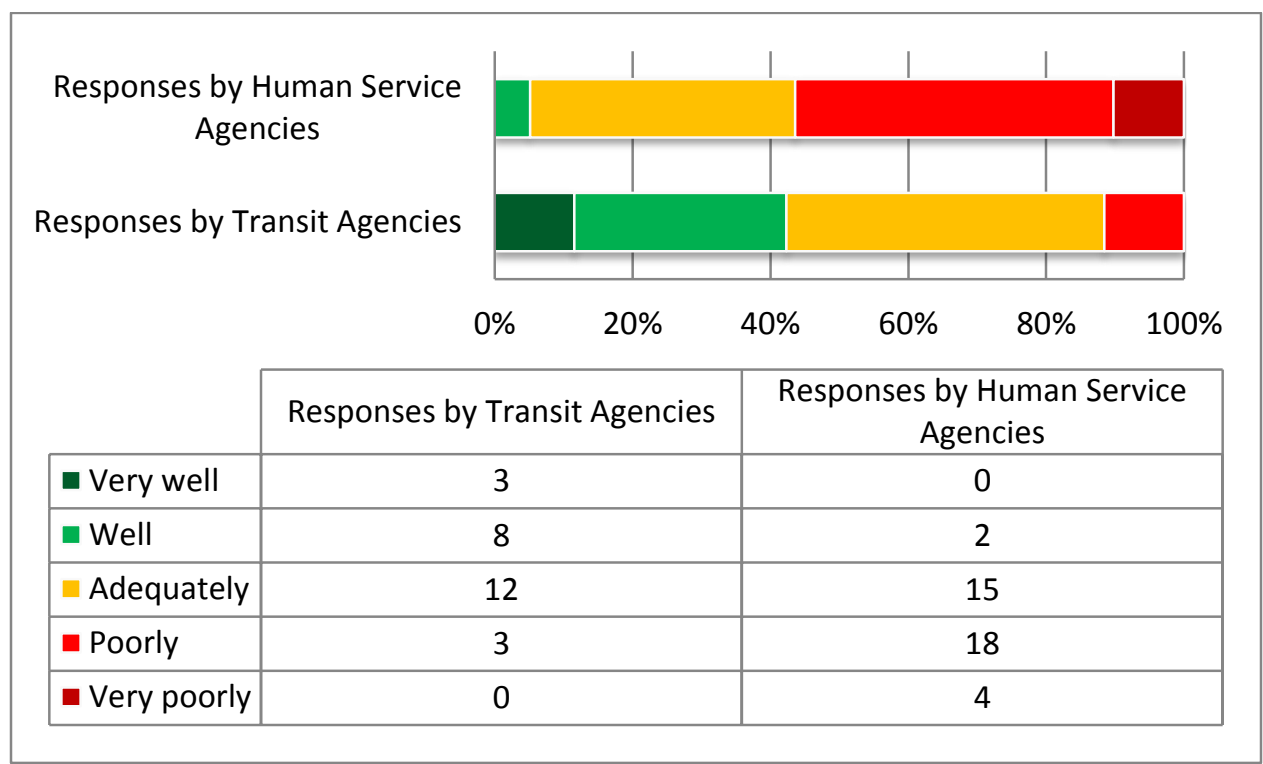

Figure 6.7 How Well the Needs of Residents are Being Met 
Responses from human service agencies were mapped according to the counties they serve. Answers were converted to a scale where very poorly $=0$, poorly $=1$, adequately $=2$, well $=3$, and very well $=4$, and responses were averaged for each county, as shown in Figure 6.8. Lowest scores were found in the northern parts of the state.

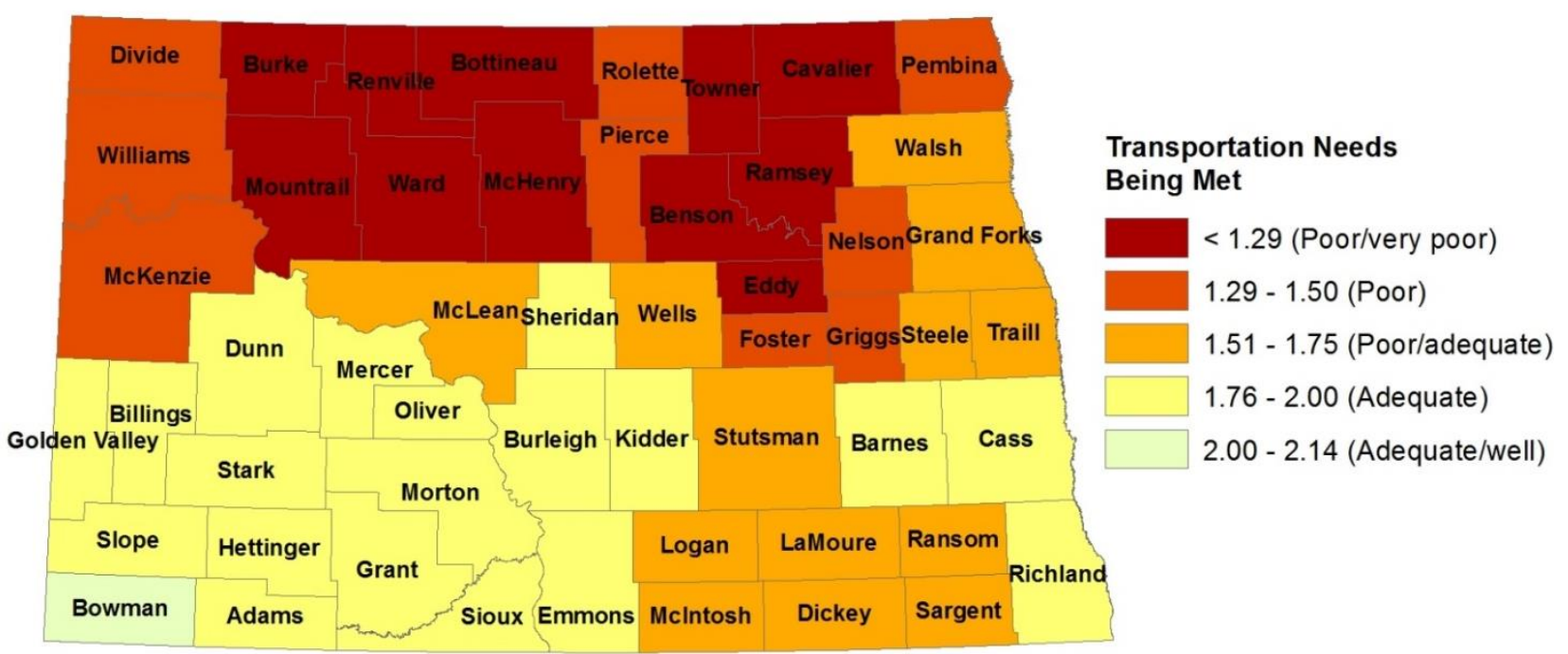

Figure 6.8 Responses from Human Service Agencies on How Well Transportation Needs are Being Met

Finally, transit providers were asked if they had any additional comments about the needs of their agency and their service area residents or issues and challenges they are facing. Detailed comments are shown in Appendix G.

\subsection{Findings from Previous Studies}

\subsubsection{MPO Studies}

Additional evidence regarding transit needs in urban areas can be obtained from recent studies published by the state's three metropolitan planning organizations (MPOs). MPOs for the Fargo, Bismarck, and Grand Forks urban areas publish transit development plans (TDPs) every five years. The TDP is developed under a five-year planning horizon and is intended to identify strategies and recommendations to improve transit service delivery in the metro areas. The three MPOs each completed their most recent TDPs in 2012. The MPOs also publish a long-range transportation plan (LRTP) every five years and other studies that address the transit needs for the metro area.

\section{Fargo-West Fargo}

The most recent TDP for the Fargo metro area, adopted in 2012 by the Fargo-Moorhead Metropolitan Council of Governments (Metro COG), identified the following as being key issues of critical importance:

- Reliability of service and on-time performance: MATBUS was having issues keepings its fixedroute buses on time. 
- $\quad$ Transfers: Reliance on transfers was making the service less convenient.

- Capacity: Capacity issues were found on certain routes.

- Route frequency: Increased ridership on some routes was found to warrant more frequent service.

- Span of service needs: A need for Sunday fixed-route service and later evening fixed-route service was identified.

- Geographic areas with service needs: The metro area had grown significantly, and areas were identified as needing service.

- $\quad$ Paratransit: The ability to stabilize rising operating costs while maintaining service and efficiency was identified as a major challenge.

Since this TDP was completed, MATBUS has implemented a number of changes to address these issues, such as interlining routes to reduce transfers and improve service reliability, purchasing 40 -foot buses to increase capacity, increasing service frequency to every 15 minutes on a high-demand route, and extending evening service by an hour for several routes and the paratransit system. Other recommendations from the TDP have not been implemented, such as fixed-route service on Sundays, earlier morning service (begin service one hour earlier on weekdays), a downtown circulator route, further frequency improvements, a new express route from the West Acres Shopping Center to the North Dakota State University (NDSU) campus, new service to the Industrial Park, and new service to Davies High School and along $25^{\text {th }}$ Street. Implementing these recommendations will require additional resources. As noted in the TDP, there is also a need for more shelters throughout the city.

Metro COG published its most recent LRTP in 2014. As discussed in this report, a minimum vision for MATBUS is to provide for a growth in transit service hours and service miles equal to or greater than population growth, with the growth being through expanded coverage, increased frequency, or extended service hours.

The LRTP's transit vision plan makes the following points: as the region increases in population and the population ages, transit will become more important; as the metro area grows, density may increase in

existing development areas, which will create the trip density needed to support transit; current service frequency is very good for a metro area of its size, but as the region grows and ridership increases, frequency of service could also increase, which would attract additional choice riders; current service hours are also good, but not all routes have evening service, or the frequency of this service is reduced; demand for shelters, benches, and other transit support facilities will grow as ridership and service increase; the fleet needs to expand if service is to be increased, and buses need to be regularly replaced; and as the fleet continues to expand, the current MATBUS maintenance facility will exceed its capacity.

\section{Bismarck-Mandan}

The most recent TDP for Bismarck-Mandan, published in 2012, recommended that fixed-route services should be expanded in terms of service frequency and, in some cases, service span, and that some resources should be shifted from paratransit services to fixed-route operations to offer a more equitable distribution of service. 
Fixed-route service frequency is an important factor for quality of service. At the time the TDP was developed, most of the routes in the system operated with a one-hour headway during peak periods and a two-hour headway during the midday period. The exceptions were one route that ran every 30 minutes during peak periods and one hour during midday, and another route that ran every two hours throughout the day. The TDP recommended a minimum headway of 60 minutes midday and 30 minutes peak. Service frequencies have not increased to these recommended levels, remaining at the levels from when the TDP was developed.

The TDP also made other recommendations for the fixed-route service, such as enhancing ridership rather than providing coverage, providing bi-directional service rather than one-way loops, minimizing double transfers, and de-emphasizing service to elementary and middle schools. The report suggested future expansions could include later service hours, Sunday service, and new service to Lincoln and the University of Mary.

The TDP recommended the creation of a single transit center in central Bismarck that is exclusive to the fixed-route service. As noted in the report, the current transfer centers are not permanent facilities and are limited in terms of available space, and a new dedicated passenger transfer facility will allow the system to grow.

Some of the increase in service for the fixed-route system could be funded by shifting money away from the demand-response service, as recommended by the TDP. The report recommends that the transit agency should encourage riders to use the fixed-route service if possible, while considering stricter eligibility requirements for the paratransit service, so that the service operates more like an ADArequired complementary service.

The Bismarck-Mandan MPO is working on its 2015-2040 LRTP, which includes further study of the recommendations from the TDP.

\section{Grand Forks}

The MPO for the Grand Forks metro area also released its most recent TDP in 2012. The plan's recommendations addressed service needs, capital improvements, and the need to better integrate transit planning and land-use planning. The TDP made recommendations for route changes, from minor to major changes, to improve on-time performance and reduce transfers and travel time. The plan proposed a more significant modification to the route structure that would require the addition of a new transit center near the Altru Medical Center. It also suggested adding new routes or modifying routes to provide access to areas not previously served. To improve on-time performance, the plan recommended adding designated stops in place of flag stops. The most recent update to the metro area's LRTP, published in 2013, reiterated the findings from the TDP. 


\subsubsection{Other Studies}

Previous studies published by the Upper Great Plains Transportation Institute have demonstrated the need for transit services across the state for people with disabilities and older adults (Mattson et al. 2010, Mattson 2009).

Mattson et al. (2010) showed a need for service improvements for people with disabilities in North Dakota. This study surveyed people with disabilities across the state to assess existing and needed community transportation services. Responses from the 131 survey participants showed that a significant percentage desired more trips than they were taking, and lack of transportation appeared to be the main limiting factor. The survey revealed significant dissatisfaction with available transportation options both in the community and for long-distance trips. While individuals from both urban and rural areas were dissatisfied, the level of dissatisfaction was greatest in rural areas. The most significant concerns with public transportation were regarding service availability. Respondents were most dissatisfied with unavailable or insufficient weekend and holiday hours, and they also expressed dissatisfaction with waiting time, scheduling procedures, and ride reservation time.

A survey conducted by AARP of its North Dakota members in 2008 revealed the importance of transportation to older adults across the state (Mattson 2009). While most AARP members in the state continue to drive, $80 \%$ of the respondents said that increased access to transit is important to them as they age.

\subsection{Transit Goals and Gaps}

To identify gaps in service and unmet mobility needs requires a determination of the desired or acceptable levels of service that should be available in different parts of the state. In the previous mobility study for North Dakota conducted by Mielke et al. (2005), the project steering committee discussed the issue of how much mobility is needed and the role that government, especially state government, should play in assuring this mobility. The committee recognized that mobility needs vary by geographic area, personal characteristics, and trip purposes, and that the range of options available to improve mobility varies by region of the state and trip purpose. Therefore, they developed a list of considerations influencing mobility needs and used them to develop desired levels of mobility. Mielke et al. (2005) created a framework to specify base levels of public transportation services that should be available in each area of the state for various trip purposes and for several modes of local transportation. The resulting matrix, presented in Table 6.3, shows the base levels of governmentsupported services for various demographic groups and geographical areas. 
Table 6.3 Mobility Goals for North Dakota Developed by Mielke et al. (2005)

\begin{tabular}{|c|c|c|c|c|c|c|}
\hline $\begin{array}{l}\text { Demographic } \\
\text { Group/Geographic } \\
\text { Area }\end{array}$ & Pre-School & Grades K-12 & Adult & $\begin{array}{c}\text { Seniors Age } \\
60+\end{array}$ & $\begin{array}{l}\text { Low } \\
\text { Income }\end{array}$ & $\begin{array}{c}\text { People with } \\
\text { Disabilities }\end{array}$ \\
\hline $\begin{array}{l}\text { Rural Areas and } \\
\text { Cities Under 4,500 }\end{array}$ & $\begin{array}{l}\text { Head Start } \\
\text { and } \\
\text { Emergency }\end{array}$ & $\begin{array}{l}\text { School and } \\
\text { Emergency }\end{array}$ & $\begin{array}{l}\text { Weekly Dial- } \\
\text { a-Ride and } \\
\text { Emergency }\end{array}$ & $\begin{array}{l}\text { Weekly } \\
\text { Dial-a-Ride } \\
\text { and } \\
\text { Emergency }\end{array}$ & $\begin{array}{l}\text { Weekly } \\
\text { Dial-a-Ride, } \\
\text { Medicaid, } \\
\text { TANF, and } \\
\text { Emergency }\end{array}$ & $\begin{array}{l}\text { Weekly Dial- } \\
\text { a-Ride, Voc. } \\
\text { Rehab, and } \\
\text { Emergency }\end{array}$ \\
\hline $\begin{array}{l}\text { Cities } 4,500- \\
20,000\end{array}$ & $\begin{array}{l}\text { Head Start, } \\
\text { Taxi, and } \\
\text { Emergency }\end{array}$ & $\begin{array}{l}\text { School, Taxi, } \\
\text { and } \\
\text { Emergency }\end{array}$ & $\begin{array}{l}\text { Daily Dial-a- } \\
\text { Ride, Taxi, } \\
\text { and } \\
\text { Emergency }\end{array}$ & $\begin{array}{l}\text { Daily Dial-a- } \\
\text { Ride, Taxi, } \\
\text { and } \\
\text { Emergency }\end{array}$ & $\begin{array}{l}\text { Daily Dial-a- } \\
\text { Ride, Taxi, } \\
\text { Medicaid, } \\
\text { TANF, and } \\
\text { Emergency }\end{array}$ & $\begin{array}{l}\text { Daily Dial-a- } \\
\text { Ride, Taxi, } \\
\text { Voc. Rehab, } \\
\text { and } \\
\text { Emergency }\end{array}$ \\
\hline Cities Over 20,000 & $\begin{array}{l}\text { Head Start, } \\
\text { Fixed-Route, } \\
\text { Taxi, and } \\
\text { Emergency }\end{array}$ & $\begin{array}{l}\text { School, } \\
\text { Fixed-Route, } \\
\text { Taxi, and } \\
\text { Emergency }\end{array}$ & $\begin{array}{l}\text { Daily Fixed- } \\
\text { Route, Taxi, } \\
\text { and } \\
\text { Emergency }\end{array}$ & $\begin{array}{l}\text { Daily Fixed- } \\
\text { Route, Taxi, } \\
\text { and } \\
\text { Emergency }\end{array}$ & $\begin{array}{l}\text { Daily Fixed- } \\
\text { Route, Taxi, } \\
\text { Medicaid, } \\
\text { TANF, and } \\
\text { Emergency }\end{array}$ & $\begin{array}{l}\text { Daily Dial-a- } \\
\text { Ride, Fixed- } \\
\text { Route, Taxi, } \\
\text { Voc. Rehab. } \\
\text { and } \\
\text { Emergency }\end{array}$ \\
\hline
\end{tabular}

While the Mielke et al. (2005) study had a broad scope that considered a wide range of mobility options, the current study is focused on services provided by public transportation agencies. Therefore, the analysis focuses on demand-response, or dial-a-ride, and fixed-route transit services, without specifically examining other types of mobility services listed in Table 6.3.

Regarding goals for demand-response and fixed-route service, these guidelines recommend a base level of weekly dial-a-ride service in rural areas and cities under 4,500, daily dial-a-ride service in cities 4,500 to 20,000 , and daily fixed-route service in cities over 20,000 . The first of these goals are being met, as all counties in the state have at least a weekly demand-response service.

As shown previously in Figure 5.1, many counties have service at least 3-5 days per week. However, there are some areas with service just once or twice a week and this might not be considered an adequate level of service, as reflected in the comments received by transit providers and human service agencies. Many respondents mentioned a need for more frequent service in rural areas, especially for medical trips.

Cities with a population of 4,500 to 20,000 all have demand-response service at least five days per week, but weekend services and evening services are limited. The greatest need in these communities is for evening and weekend service.

Among cities with a population over 20,000, Fargo-West Fargo, Bismarck-Mandan, and Grand Forks have fixed-route service six days per week, and Minot has fixed-route service five days per week. Compared to the other urban areas, the service in Bismarck-Mandan has been oriented more toward paratransit, with more trips being provided by paratransit than by fixed-route service. Their paratransit system 
serves people over age 60 and those with disabilities. The fixed-route service in Bismarck-Mandan is relatively new, having begun in 2004 .

In Minot, there is demand for expanding the fixed-route service, as reflected in the survey comments. Fixed-route service in Minot is currently limited, with no weekend or evening service. As the city continues to grow, it is anticipated that demand for expanding the service will grow as well.

The cities of Williston and Dickinson do not have fixed-route service but may have the demand to support such service. These cities have quickly surpassed the 20,000 population target for fixed-route service. Williston's population increased from 14,716 in the 2010 Census to a 2013 Census estimate of 20,850, and it may currently be much higher. Dickinson's population grew from 17,787 in the 2010 Census to 20,826 in 2013 . These cities may need to begin planning for fixed-route service. The transit director in Dickinson noted that the community needs a fixed-route system, and they recently received a $\$ 150,000$ fixed-route planning grant.

Based on comments received from the survey and through the steering committee, transit goals were updated and are presented in Table 6.4.

Table 6.4 Transit Goals for North Dakota

\begin{tabular}{lll}
\hline Geographic Area & \multicolumn{1}{c}{$\begin{array}{c}\text { Base-Level Transit } \\
\text { Service Goal }\end{array}$} & $\begin{array}{c}\text { Preferred Transit Service } \\
\text { Goal }\end{array}$ \\
\hline $\begin{array}{l}\text { Rural Areas and } \\
\text { Cities Under 4,500 }\end{array}$ & $\begin{array}{l}\text { Demand-response 3 } \\
\text { days per week }\end{array}$ & $\begin{array}{l}\text { Demand-response } 5 \text { days } \\
\text { per week }\end{array}$ \\
$\begin{array}{l}\text { Cities 4,500- } \\
\text { 20,000 }\end{array}$ & $\begin{array}{l}\text { Demand-response 5 } \\
\text { days per week }\end{array}$ & $\begin{array}{l}\text { Demand-response } 7 \text { days } \\
\text { per week }\end{array}$ \\
Cities Over 20,000 & $\begin{array}{l}\text { Fixed-route and } \\
\text { demand-response 6 } \\
\text { days per week }\end{array}$ & $\begin{array}{l}\text { Fixed-route 6 days per } \\
\text { week; demand-response } \\
\text { 7 days per week }\end{array}$ \\
\hline
\end{tabular}




\section{FUNDING NEEDS TO MEET TARGET LEVELS}

\subsection{Current Service Levels by Region}

To evaluate service levels in North Dakota, the state was divided into 22 regions, consisting of the three urban areas, (Fargo-West Fargo, Bismarck-Mandan, and Grand Forks), and 19 regions consisting of one or multiple counties. These regions were determined based on the current service boundaries of the state's transit providers. County-level data are not available for every county because some providers serve multiple counties and do not report data by county. Table 7.1 provides a description of these regions, the transit providers in each, and current and projected populations. Table 7.2 provides total and per capita service data for each region for the following: trips provided, vehicle revenue miles, vehicle revenue hours, and number of vehicles in service. For urban areas, the demand-response and fixed-route data are separated. Fargo area demand-response service includes Metro Area Transit's complementary paratransit service in addition to services from Handi-Wheels and Valley Senior Services.

Table 7.1 Regional Transit Service Areas and Population Data

\begin{tabular}{|c|c|c|c|c|c|}
\hline Region & Counties & Providers & $\begin{array}{l}\text { Population } \\
2013\end{array}$ & $\begin{array}{l}\text { Projected } \\
\text { Population } \\
2020\end{array}$ & $\begin{array}{l}\text { Projected } \\
\text { Population } \\
2025\end{array}$ \\
\hline \multicolumn{6}{|l|}{ Rural } \\
\hline Northwest & Divide, Williams, McKenzie & $\begin{array}{l}\text { Northwest Public Transit, Wildrose, } \\
\text { Trenton }\end{array}$ & 41,223 & 66,938 & 73,164 \\
\hline Golden Valley/Billings & Golden Valley, Billings & Golden Valley/Billings Cncl. On Aging & 2,697 & 3,388 & 3,669 \\
\hline Southwest & Slope, Hettinger, Bowman, Adams & Southwest Transportation Services & 8,995 & 10,298 & 10,765 \\
\hline Stark County & Stark & Stark County (Elder Care) & 28,212 & 39,195 & 42,191 \\
\hline Souris Basin/Minot & $\begin{array}{l}\text { Burke, Mountrail, Renville, Ward, } \\
\text { Bottineau, McHenry, Pierce }\end{array}$ & $\begin{array}{l}\text { Souris Basin Transportation, City of } \\
\text { Minot, Kenmare Wheels \& Meals, Inc. }\end{array}$ & 99,389 & 121,425 & 121,443 \\
\hline West River & $\begin{array}{l}\text { Dunn, Mercer, McLean, Oliver, } \\
\text { Burleigh (excluding Bismarck), } \\
\text { Morton (excluding Mandan), Grant }\end{array}$ & $\begin{array}{l}\text { West River Transit, Hazen Busing, Glen } \\
\text { Ullin Transportation }\end{array}$ & 57,048 & 62,961 & 66,774 \\
\hline Sioux County & Sioux & Standing Rock Public Transportation & 4,430 & 4,693 & 4,937 \\
\hline Rolette County & Rolette & $\begin{array}{l}\text { Nutrition United/Rolette Co. Transp., } \\
\text { Turtle Mountain Transit }\end{array}$ & 14,582 & 15,172 & 15,651 \\
\hline Towner County & Towner & Cando Transportation & 2,317 & 2,301 & 2,315 \\
\hline Cavalier County & Cavalier & Cavalier County Transit & 3,896 & 3,805 & 3,773 \\
\hline Pembina County & Pembina & Pembina County Meals \& Trans & 7,181 & 7,174 & 7,060 \\
\hline Walsh County & Walsh & Walsh County Transportation & 11,104 & 10,636 & 10,314 \\
\hline Benson County & Benson & $\begin{array}{l}\text { Benson County Transportation, Spirit } \\
\text { Lake Transit }\end{array}$ & 6,877 & 7,322 & 7,686 \\
\hline Ramsey/Eddy & Ramsey, Eddy & Devils Lake Transit /Eddy Co Transit & 13,958 & 13,654 & 13,591 \\
\hline James River & Sheridan, Wells, Stutsman & $\begin{array}{l}\text { James River Public Transit, City of } \\
\text { Jamestown }\end{array}$ & 26,630 & 27,877 & 28,733 \\
\hline Kidder County & Kidder & Kidder/Emmons Senior Services & 2,428 & 2,319 & 2,246 \\
\hline South Central & $\begin{array}{l}\text { Foster, Griggs, Barnes, LaMoure, } \\
\text { Logan, McIntosh, Emmons }\end{array}$ & South Central Adult Services & 29,204 & 28,917 & 28,877 \\
\hline Dickey County & Dickey & Dickey County Transportation & 5,248 & 5,313 & 5,296 \\
\hline Red River Valley & $\begin{array}{l}\text { Nelson, Grand Forks (excluding City } \\
\text { of Grand Forks), Steele, Traill, Cass } \\
\text { (excluding Fargo-West Fargo), } \\
\text { Ransom, Richland, Sargent }\end{array}$ & $\begin{array}{l}\text { Valley Senior Services, Nelson County } \\
\text { Transportation }\end{array}$ & 72,585 & 72,585 & 72,585 \\
\hline \multicolumn{6}{|l|}{ Urban } \\
\hline Bismarck-Mandan & Burleigh and Morton metro areas & Bis-Man Transit Board & 86,921 & 102,046 & 112,797 \\
\hline Grand Forks & Grand Forks metro area & Cities Area Transit & 54,932 & 59,179 & 62,650 \\
\hline Fargo-West Fargo & Cass metro area & $\begin{array}{l}\text { Fargo Metro Area Transit, Handi- } \\
\text { Wheels, Valley Senior Services }\end{array}$ & 143,536 & 157,070 & 168,660 \\
\hline
\end{tabular}

Sources: 2013 population data from the U.S. Census, population estimates from the Center for Social Research for rural counties (2012) and the MPOs for urban areas (Fargo-Moorhead Metro COG 2014, Grand Forks-East Grand Forks MPO 2013, Bismarck Community Development Department 2014). Population projections for rural Cass and Grand Forks counties were not available. 
Table 7.2 Transit Service Data by Region, 2013

\begin{tabular}{|c|c|c|c|c|c|c|c|c|}
\hline Region & $\begin{array}{c}\text { Trips } \\
\text { Provided }\end{array}$ & $\begin{array}{l}\text { Vehicle } \\
\text { Miles }\end{array}$ & $\begin{array}{l}\text { Vehicle } \\
\text { Hours }\end{array}$ & $\begin{array}{l}\text { Vehicles } \\
\text { Available }\end{array}$ & $\begin{array}{c}\text { Trips } \\
\text { Provided } \\
\text { Per } \\
\text { Capita } \\
\end{array}$ & $\begin{array}{l}\text { Vehicle } \\
\text { Miles } \\
\text { Per } \\
\text { Capita } \\
\end{array}$ & $\begin{array}{c}\text { Vehicle } \\
\text { Hours } \\
\text { Per } \\
\text { Capita } \\
\end{array}$ & $\begin{array}{c}\text { Active } \\
\text { Fleet Per } \\
1,000 \\
\text { People } \\
\end{array}$ \\
\hline \multicolumn{9}{|l|}{ Rural Transit } \\
\hline Northwest & 44,254 & 203,517 & 27,756 & 16 & 1.07 & 4.9 & 0.67 & 0.39 \\
\hline $\begin{array}{l}\text { Golden } \\
\text { Vallev/Billings }\end{array}$ & 2,901 & 90.844 & 3.720 & 3 & 1.08 & 33.7 & 138 & 111 \\
\hline Southwest & 17,024 & 68,834 & 6,025 & 6 & 1.89 & 7.7 & 0.67 & 0.67 \\
\hline Stark County & 44,403 & 189,235 & 18,459 & 12 & 1.57 & 6.7 & 0.65 & 0.43 \\
\hline Souris Basin/Minot & 217,584 & 584,200 & 46,209 & 40 & 2.19 & 5.9 & 0.46 & 0.40 \\
\hline West River & 52,085 & 192,442 & 12,789 & 18 & 0.91 & 3.4 & 0.22 & 0.32 \\
\hline Sioux County ${ }^{a}$ & 22,418 & 283,131 & 7,792 & 12 & 1.58 & 20.0 & 0.55 & 0.85 \\
\hline Rolette County & 7,734 & 125,196 & 4,861 & 8 & 0.53 & 8.6 & 0.33 & 0.55 \\
\hline Towner County & 5,651 & 45,377 & 3,260 & 2 & 2.44 & 19.6 & 1.41 & 0.86 \\
\hline Cavalier County & 5,088 & 15,157 & 2,260 & 2 & 1.31 & 3.9 & 0.58 & 0.51 \\
\hline Pembina County & 6,659 & 101,350 & 4,851 & 4 & 0.93 & 14.1 & 0.68 & 0.56 \\
\hline Walsh County & 8,529 & 62,308 & 3,567 & 3 & 0.77 & 5.6 & 0.32 & 0.27 \\
\hline Benson County & 5,986 & 86,553 & 3,182 & 12 & 0.87 & 12.6 & 0.46 & 1.74 \\
\hline Ramsey/Eddy & 29,472 & 55,723 & 6,778 & 5 & 2.11 & 4.0 & 0.49 & 0.36 \\
\hline James River & 77,493 & 289,644 & 20,955 & 16 & 2.91 & 10.9 & 0.79 & 0.60 \\
\hline Kidder County & 8,739 & 48,702 & 1,785 & 4 & 3.60 & 20.1 & 0.74 & 1.65 \\
\hline South Central & 112,665 & 652,751 & 49,389 & 31 & 3.86 & 22.4 & 1.69 & 1.06 \\
\hline Dickey County & 5,167 & 10,507 & 1,809 & 2 & 0.98 & 2.0 & 0.34 & 0.38 \\
\hline Red River Valley ${ }^{\mathrm{b}}$ & 28,666 & 224,384 & 12,379 & 14 & 0.39 & 3.1 & 0.17 & 0.19 \\
\hline \multicolumn{9}{|c|}{ Urban Transit Fixed-Route } \\
\hline Bismarck-Mandan & 135,466 & 300,704 & 19,944 & 10 & 1.56 & 3.5 & 0.23 & 0.12 \\
\hline Grand Forks & 364,317 & 382,632 & 25,124 & 11 & 6.63 & 7.0 & 0.46 & 0.20 \\
\hline Fargo-West Fargo & $1,682,267$ & 927,601 & 73,730 & 32 & 11.72 & 6.5 & 0.51 & 0.22 \\
\hline \multicolumn{9}{|c|}{ Urban Transit Demand-Response } \\
\hline Bismarck-Mandan & 160,582 & 628,858 & 44,488 & 32 & 1.85 & 7.23 & 0.51 & 0.37 \\
\hline Grand Forks & 52,551 & 190,734 & 20,110 & 9 & 0.96 & 3.47 & 0.37 & 0.16 \\
\hline Fargo-West Fargo ${ }^{b}$ & 106,398 & 647,510 & 52,800 & 28 & 0.74 & 4.51 & 0.37 & 0.20 \\
\hline
\end{tabular}

aPer capita estimates for Sioux County were adjusted to account for the population in South Dakota served by Standing Rock Public Transit.

${ }^{b}$ Valley Senior Services provides service in both the Fargo metro area and the rural Red River Valley. For this analysis, their rural services were considered part of Red River Valley rural transit, and their urban services were considered part of Fargo-West Fargo urban demand-response transit. 


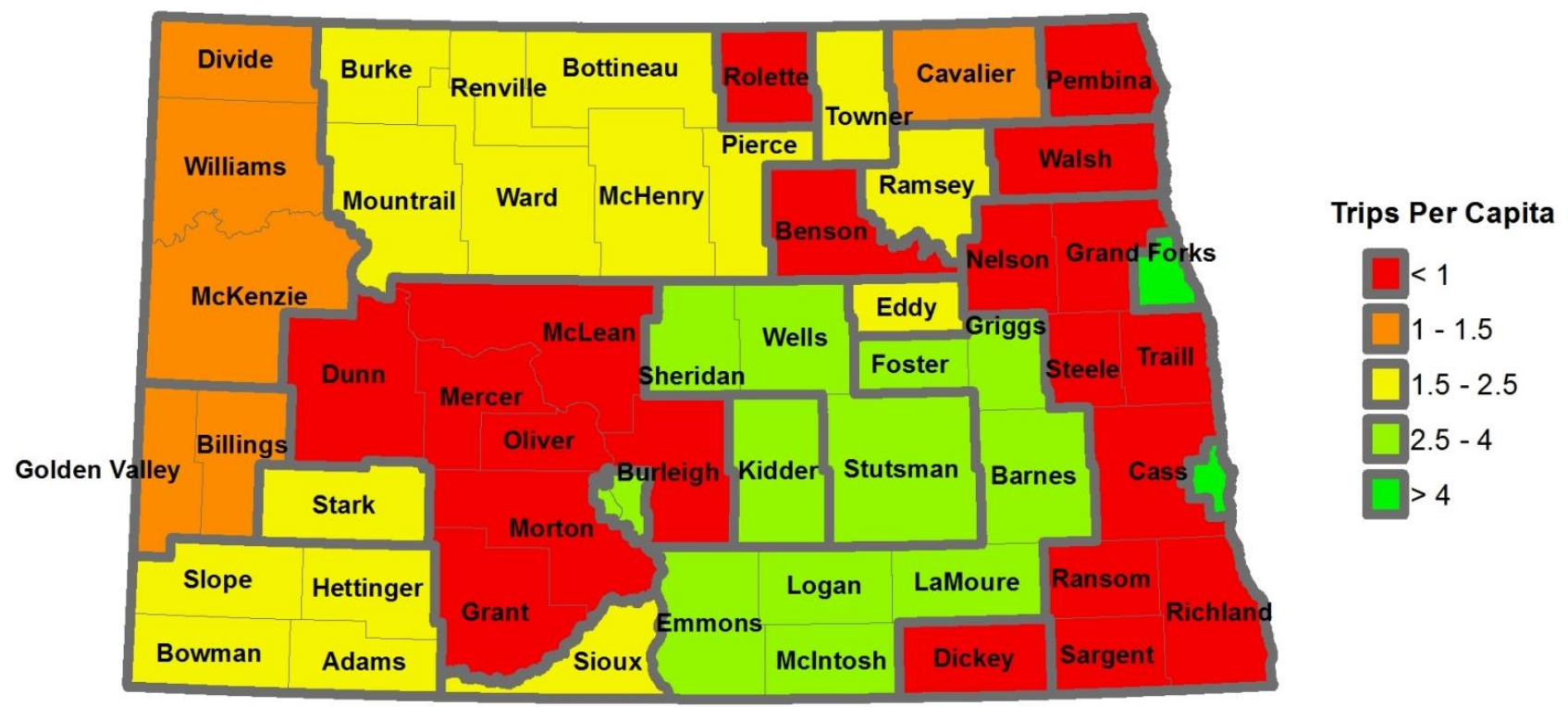

Figure 7.1 Trips Provided Per Capita, by Region

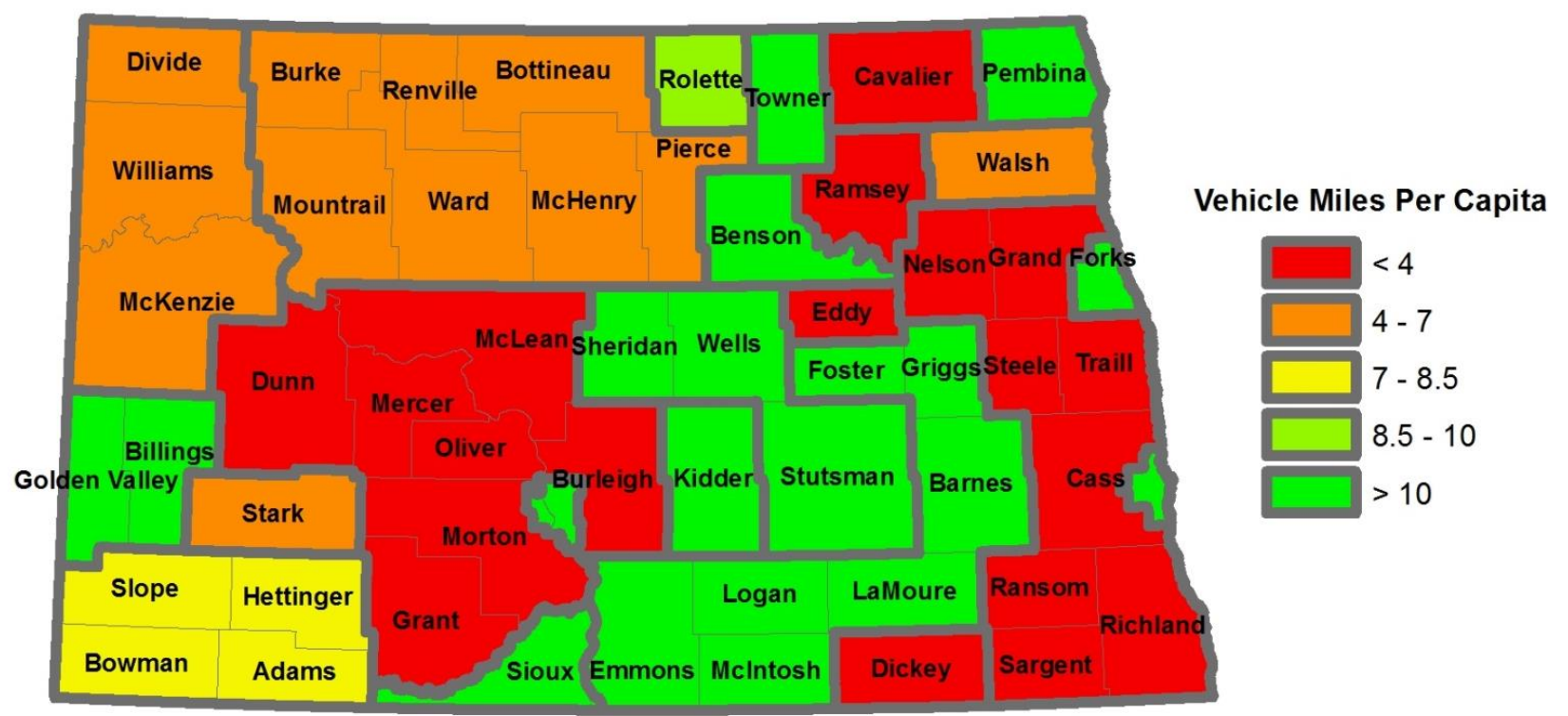

Figure 7.2 Vehicle Miles of Service Per Capita, by Region 


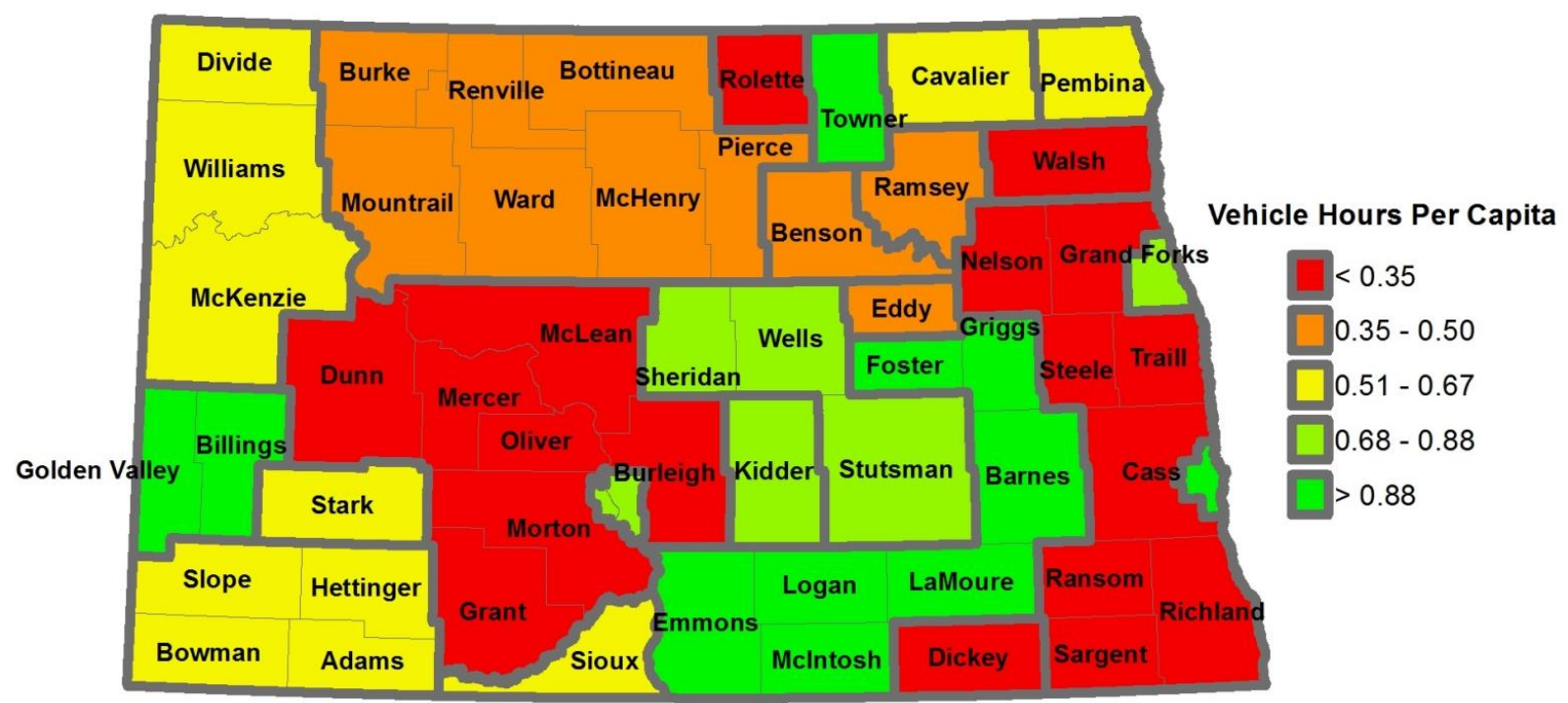

Figure 7.3 Vehicle Hours of Service Per Capita, by Region

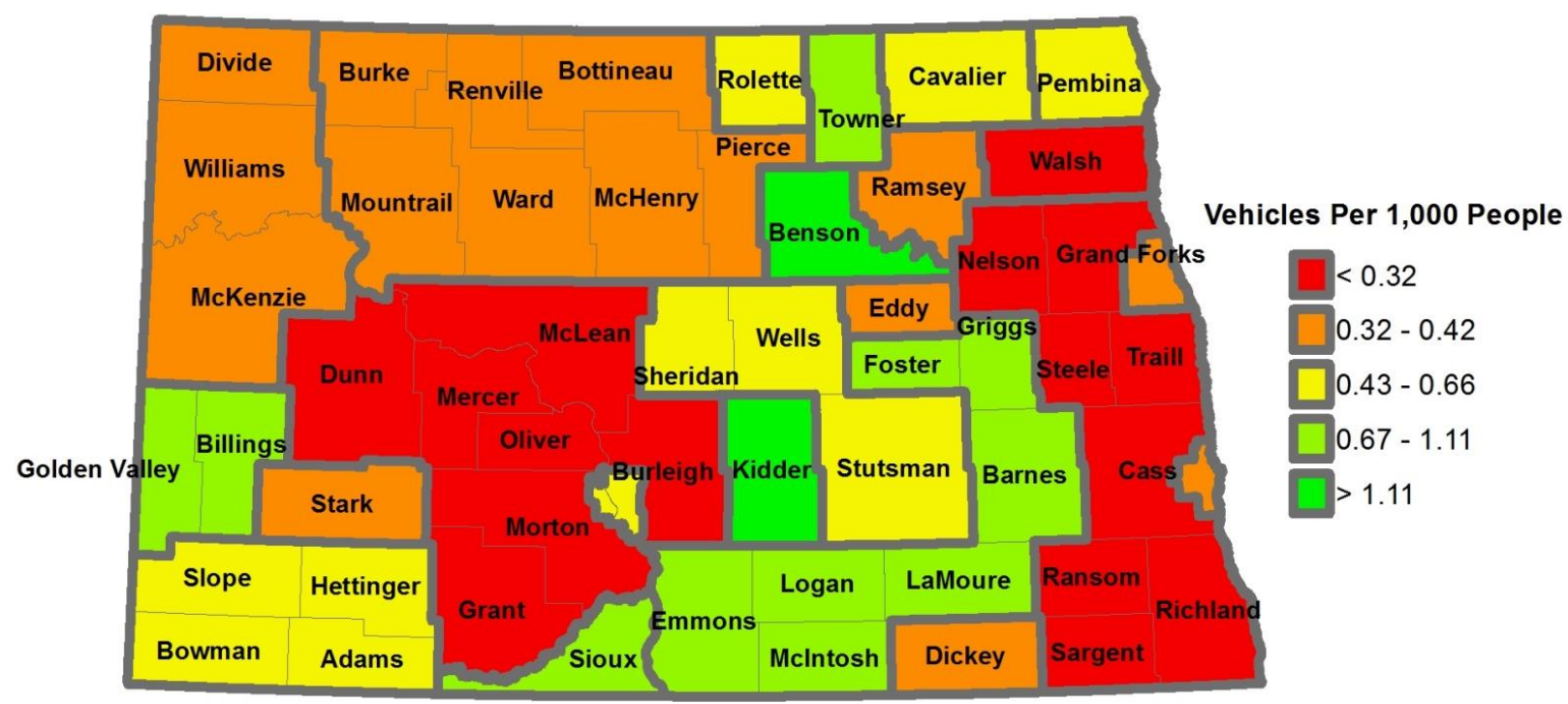

Figure 7.4 Vehicles Per 1,000 Population, by Region 
The per capita data presented in Table 7.2 and Figures 7.1-7.4 provide information about the level of service being provided, adjusted for population. Trips per capita is a measure of the amount of transit service consumed, and vehicle miles and hours per capita is a measure of transit service supplied, adjusted for population. The number of active vehicles per 1,000 population, as shown in Figure 7.4, provides information about the availability of transit vehicles and the ability of transit providers to meet demand.

Trips provided per capita is highest for the fixed-route services in urban areas, as expected, especially in Fargo-West Fargo and Grand Forks. Among the rural areas, trips per capita is highest in the South Central area, Kidder County, and the James River area, and lowest in the Red River Valley, Rolette County, Walsh County, and Benson County.

The amount of service provided, as measured by vehicle miles or hours per capita, varies significantly from area to area. Transit providers in rural areas that provide long-distance trips provide a higher number of vehicle miles per capita.

The number of active vehicles per 1,000 population is highest in Benson and Kidder Counties, and lowest in the Red River Valley, Walsh County, and the West River region. Vehicles per capita is somewhat misleading, especially when comparing rural areas to urban areas, because it does not consider differences in vehicle capacity. Urban areas appear to have a low number of vehicles per capita, but the fixed-route systems in these areas operate higher-capacity vehicles.

\subsection{Estimated Increases in Services to Meet Target Levels}

The per capita service levels provide information about how well transit agencies are meeting the needs of their service area population. Comparing these service levels to benchmarks and target levels will identify where improvements in service levels are needed. A previous analysis conducted by SURTC in a 2005 report for the NDDOT (Mielke et al. 2005) used 7.0 vehicle miles per capita as a target level for a high level of service.

Since the 2005 report, transit levels have improved throughout the state. Mielke et al. (2005) reported that the average number of vehicle miles provided per capita in rural areas was 4.7 in 2004, with 14 of 24 systems offering less than 5.0 vehicle miles of service per capita. Data from 2013 shows that the average number of vehicle miles provided per capita in rural areas is 7.4, suggesting a significant improvement over the previous decade. However, there are still some underserved areas. Six of the 18 rural regions shown in Table 7.2 had less than 5.0 vehicle miles of service per capita in 2013, and nine had less than 7.0 vehicle miles of service per capita, indicating there are a number of areas across the state not meeting this target level of service.

Vehicle miles of service per capita is a useful measure of the level of service provided, but defining a target level presents some difficulties. Generally, a higher number indicates more frequent service and greater coverage area. However, a high value might also indicate a very small population that requires very long trips. 
Because of longer travel distances, providing an equal level of service would require more miles per capita in rural areas. Areas with denser population and shorter travel distances could provide the same level of service with fewer vehicle miles. Further, areas with higher concentrations of older adults, lowincome households, and other transportation-disadvantaged populations would also be expected to provide more miles of service per capita. Nevertheless, low vehicle miles per capita statistics suggest that many mobility needs are not being met by the existing service and that service expansion may be warranted.

Because there is no single measure that describes the adequacy of transit services in a region, this study examines three different measures and establishes benchmarks for each: trips provided per capita, vehicles miles per capita, and vehicle hours per capita. Benchmarks were established based on national average data, as shown in Table 7.3. The rural benchmarks are national averages calculated with national rural service and population data from the 2014 Rural Transit Fact Book (Mattson 2014). The small urban benchmarks are averages for transit agencies serving areas with a population of 50,000 to 150,000, calculated from 2012 NTD data. Because of geographic and population differences between regions, a region is not necessarily expected to meet every benchmark, but failure to meet all or a majority of the target levels suggests that service expansion may be needed.

Table 7.3 Rural and Small Urban Transit Service Benchmarks: National Averages

\begin{tabular}{lccc}
\hline & Trips Per Capita & Miles Per Capita & Hours Per Capita \\
\hline Rural & 2.0 & 8.5 & 0.5 \\
Small Urban Fixed-Route & 10.9 & 6.9 & 0.5 \\
Small Urban Demand-Response & 0.5 & 2.7 & 0.2 \\
\hline
\end{tabular}

Multiple scenarios were analyzed to determine needed increases in service and the funding required to provide that service. The scenarios, which require increasingly higher levels of service, are described below.

Scenario 1: Each region must meet at least one of the three benchmarks from Table 7.3.

Scenario 2: Each region must meet at least one of the three benchmarks, and regions determined to have LOS 5 or lower, as determined by hours and days of service and shown in Figure 5.3, must have at least a $20 \%$ increase in service. Further, transit service must increase at a rate equal to or greater than projected population growth and at least half the projected rate of increase for the older adult (age 65+) population.

Scenario 3: Each region must meet at least two of the three benchmarks, and other requirements from Scenario 2 must be met.

Scenario 4: The requirements of Scenario 3 must be met, and service must increase at a minimum of $10 \%$ in each region. 
Increases in service required to meet each of these scenarios is measured using vehicle miles. The number of vehicle miles needed to add an additional trip is determined by each region's average trip distance, and additional vehicle hours are converted to vehicle miles based on average miles per hour for each region.

Scenarios 2-4 require at least a $20 \%$ increase in vehicle miles in regions with LOS 5 or lower. This increase is needed to expand days or hours of service in regions not currently meeting target levels of service, as measured by service span. These regions are Golden Valley/Billings, the Southwest, Souris Basin/Minot, West River, Towner County, Cavalier County, and Dickey County.

In addition to analyzing potential increases in service, this study also analyzes the impacts of projected population increases and rising operating costs. As population increases, service will need to increase further to meet target levels. Using projected population data for 2020 and 2025, the study estimated the increase in service needed to meet the four scenarios. Scenarios 2-4 assure that, even among regions already meeting benchmark values, transit services will increase at a rate equal to the rate of population growth. The scenarios also provide for service increases in areas expected to experience an increase in the older adult population.

Because the Bismarck-Mandan demand-response service far exceeds the benchmark values, even after accounting for projected population increases, and the recent TDP recommended shifting resources away from the paratransit service, this analysis does not recommend any increases in demand-response service for Bismarck-Mandan.

Table 7.4 shows the increase in vehicle miles needed in each scenario given the current population. Table 7.5 presents the results given projected 2020 and 2025 populations. 
Table 7.4 Increase in Vehicle Miles Needed in each Scenario, Given Current Population

\begin{tabular}{|c|c|c|c|c|c|}
\hline \multirow[b]{2}{*}{ Region } & \multirow{2}{*}{$\begin{array}{c}\text { Current } \\
\text { Vehicle } \\
\text { Miles }\end{array}$} & \multicolumn{4}{|c|}{ Increase in Vehicle Miles } \\
\hline & & Scenario 1 & Scenario 2 & Scenario 3 & Scenario 4 \\
\hline \multicolumn{6}{|l|}{ Rural } \\
\hline Northwest & 203,517 & 0 & 0 & 146,879 & 146,879 \\
\hline Golden Valley/Billings & 90,844 & 0 & 18,169 & 18,169 & 18,169 \\
\hline Southwest & 68,834 & 0 & 13,767 & 13,767 & 13,767 \\
\hline Stark County & 189,235 & 0 & 0 & 50,567 & 50,567 \\
\hline Souris Basin/Minot & 584,200 & 0 & 116,840 & 116,840 & 116,840 \\
\hline West River & 187,381 & 229,116 & 229,116 & 236,780 & 236,780 \\
\hline Sioux County & 283,131 & 0 & 0 & 0 & 28,313 \\
\hline Rolette County & 125,196 & 0 & 0 & 62,585 & 62,585 \\
\hline Towner County & 45,377 & 0 & 9,075 & 9,075 & 9,075 \\
\hline Cavalier County & 15,157 & 0 & 3,031 & 8,055 & 8,055 \\
\hline Pembina County & 101,350 & 0 & 0 & 0 & 10,135 \\
\hline Walsh County & 62,308 & 32,076 & 32,076 & 34,674 & 34,674 \\
\hline Benson County & 86,553 & 0 & 0 & 6,977 & 6,977 \\
\hline Ramsey/Eddy & 55,723 & 0 & 0 & 1,652 & 1,652 \\
\hline James River & 289,644 & 0 & 0 & 0 & 28,964 \\
\hline Kidder County & 48,702 & 0 & 0 & 0 & 4,870 \\
\hline South Central & 652,751 & 0 & 0 & 0 & 65,275 \\
\hline Dickey County & 10,507 & 4,734 & 4,734 & 10,836 & 10,836 \\
\hline Red River Valley & 224,384 & 392,589 & 392,589 & 433,460 & 433,460 \\
\hline Total Rural & $3,329,855$ & 658,514 & 819,397 & $1,150,317$ & $1,287,875$ \\
\hline$\%$ increase & & $20 \%$ & $25 \%$ & $35 \%$ & $39 \%$ \\
\hline \multicolumn{6}{|l|}{ Urban Fixed-Route } \\
\hline Bismarck-Mandan & 300,704 & 299,051 & 299,051 & 354,568 & 354,568 \\
\hline Grand Forks & 382,632 & 0 & 0 & 35,668 & 35,668 \\
\hline Fargo-West Fargo & 927,601 & 0 & 0 & 0 & 92,760 \\
\hline Total Urban Fixed-Route & $1,610,937$ & 299,051 & 299,051 & 390,236 & 482,996 \\
\hline$\%$ increase & & $19 \%$ & $19 \%$ & $24 \%$ & $30 \%$ \\
\hline \multicolumn{6}{|l|}{ Urban Demand-Response } \\
\hline Bismarck-Mandan & 628,858 & 0 & 0 & 0 & 0 \\
\hline Grand Forks & 190,734 & 0 & 0 & 0 & 19,073 \\
\hline Fargo-West Fargo & 647,510 & 0 & 0 & 0 & 64,751 \\
\hline $\begin{array}{l}\text { Total Urban Demand- } \\
\text { Response }\end{array}$ & $1,467,102$ & 0 & 0 & 0 & 83,824 \\
\hline$\%$ increase & & $0 \%$ & $0 \%$ & $0 \%$ & $6 \%$ \\
\hline Total State & $6,407,894$ & 957,565 & $1,118,448$ & $1,540,553$ & $1,854,696$ \\
\hline$\%$ increase & & $15 \%$ & $17 \%$ & $24 \%$ & $29 \%$ \\
\hline
\end{tabular}


Table 7.5 Increase in Vehicle Miles Needed in Each Scenario, Given Projected Population for 2020 and 2025

\begin{tabular}{|c|c|c|c|c|c|c|c|c|}
\hline \multirow[b]{2}{*}{ Region } & \multicolumn{4}{|c|}{2020 Population } & \multicolumn{4}{|c|}{2025 Population } \\
\hline & Scenario 1 & Scenario 2 & Scenario 3 & Scenario 4 & Scenario 1 & Scenario 2 & Scenario 3 & Scenario 4 \\
\hline \multicolumn{9}{|l|}{ Rural } \\
\hline Northwest & 41,890 & 126,954 & 365,456 & 365,456 & 64,715 & 157,692 & 418,377 & 418,377 \\
\hline Golden Valley/Billings & 0 & 23,275 & 23,275 & 23,275 & 0 & 32,740 & 32,740 & 32,740 \\
\hline Southwest & 0 & 13,767 & 14,443 & 14,443 & 0 & 13,767 & 18,219 & 18,219 \\
\hline Stark County & 11,671 & 73,670 & 143,923 & 143,923 & 27,028 & 93,766 & 169,389 & 169,389 \\
\hline Souris Basin/Minot & 67,838 & 129,526 & 183,361 & 183,361 & 67,934 & 129,632 & 183,475 & 183,475 \\
\hline West River & 272,811 & 272,811 & 281,269 & 281,269 & 300,983 & 300,983 & 309,954 & 309,954 \\
\hline Sioux County & 0 & 18,233 & 18,233 & 28,313 & 0 & 33,580 & 33,580 & 33,580 \\
\hline Rolette County & 3,766 & 29,713 & 70,183 & 70,183 & 7,838 & 43,537 & 76,351 & 76,351 \\
\hline Towner County & 0 & 9,075 & 9,075 & 9,075 & 0 & 9,075 & 9,075 & 9,075 \\
\hline Cavalier County & 0 & 3,031 & 7,513 & 7,513 & 0 & 3,031 & 7,322 & 7,322 \\
\hline Pembina County & 0 & 4,834 & 4,834 & 10,135 & 0 & 9,683 & 9,683 & 10,135 \\
\hline Walsh County & 28,098 & 28,098 & 30,586 & 30,586 & 25,361 & 25,361 & 27,774 & 27,774 \\
\hline Benson County & 0 & 5,601 & 13,029 & 13,029 & 0 & 10,182 & 17,980 & 17,980 \\
\hline Ramsey/Eddy & 0 & 4,361 & 4,361 & 5,572 & 0 & 9,338 & 9,338 & 9,338 \\
\hline James River & 0 & 13,563 & 13,563 & 28,964 & 0 & 25,708 & 25,708 & 28,964 \\
\hline Kidder County & 0 & 1,743 & 1,743 & 4,870 & 0 & 3,750 & 3,750 & 4,870 \\
\hline South Central & 0 & 13,379 & 13,379 & 65,275 & 0 & 42,002 & 42,002 & 65,275 \\
\hline Dickey County & 4,922 & 4,922 & 11,101 & 11,101 & 4,873 & 4,873 & 11,032 & 11,032 \\
\hline Red River Valley & 392,589 & 392,589 & 433,460 & 433,460 & 392,589 & 392,589 & 433,460 & 433,460 \\
\hline Total Rural & 823,584 & $1,169,145$ & $1,642,788$ & $1,729,805$ & 891,321 & $1,341,289$ & $1,839,210$ & $1,867,312$ \\
\hline$\%$ increase & $25 \%$ & $35 \%$ & $49 \%$ & $52 \%$ & $27 \%$ & $40 \%$ & $55 \%$ & $56 \%$ \\
\hline \multicolumn{9}{|l|}{ Urban Fixed-Route } \\
\hline Bismarck-Mandan & 403,413 & 403,413 & 468,591 & 468,591 & 477,595 & 477,595 & 549,640 & 549,640 \\
\hline Grand Forks & 25,703 & 29,583 & 68,008 & 68,008 & 49,653 & 53,760 & 94,440 & 94,440 \\
\hline Fargo-West Fargo & 16,429 & 87,463 & 87,463 & 92,760 & 133,359 & 162,364 & 162,364 & 162,364 \\
\hline Total Urban Fixed-Route & 445,546 & 520,460 & 624,063 & 629,360 & 660,607 & 693,719 & 806,443 & 806,443 \\
\hline$\%$ increase & $28 \%$ & $32 \%$ & $39 \%$ & $39 \%$ & $41 \%$ & $43 \%$ & $50 \%$ & $50 \%$ \\
\hline \multicolumn{9}{|l|}{ Urban Demand-Response } \\
\hline Bismarck-Mandan & 0 & 0 & 0 & 0 & 0 & 0 & 0 & 0 \\
\hline Grand Forks & 0 & 14,746 & 14,746 & 19,073 & 0 & 26,798 & 26,798 & 26,798 \\
\hline Fargo-West Fargo & 0 & 61,054 & 61,054 & 64,751 & 0 & 113,338 & 113,338 & 113,338 \\
\hline $\begin{array}{l}\text { Total Urban Demand- } \\
\text { Response }\end{array}$ & 0 & 75,800 & 75,800 & 83,824 & 0 & 140,136 & 140,136 & 140,136 \\
\hline$\%$ increase & $0 \%$ & $5 \%$ & $5 \%$ & $6 \%$ & $0 \%$ & $10 \%$ & $10 \%$ & $10 \%$ \\
\hline Total State & $1,269,130$ & $1,765,405$ & $2,342,651$ & $2,442,989$ & $1,551,929$ & $2,175,144$ & $2,785,790$ & $2,813,891$ \\
\hline$\%$ increase & $20 \%$ & $28 \%$ & $37 \%$ & $38 \%$ & $24 \%$ & $34 \%$ & $43 \%$ & $44 \%$ \\
\hline
\end{tabular}


Under Scenario 1, the rural Red River Valley, the West River region, and Bismarck-Mandan's fixed-route system require the greatest increases in service, with significant increases also in Walsh County and Dickey County. Subsequent scenarios providing higher levels of service require significant increases in Souris Basin/Minot, the Northwest, Rolette County, Stark County, and other areas. Taking into consideration projected population increases magnifies the need for increased services in Souris Basin/Minot, the Northwest, and Stark County, as well as for the urban areas.

\subsection{Estimated Operating and Vehicles Expenses for Expanded Mobility Options}

Cost estimates for providing these increased levels of service were estimated first assuming current operating costs and then assuming a $20 \%$ increase in costs. The increased costs were considered based on a need for transit agencies to increase staff wages which would allow them to attract and retain qualified staff needed to maintain and increase service levels. Labor costs typically account for approximately $70 \%$ of total costs for rural and small urban transit agencies (Mattson and Ripplinger 2011), so an increase in wages would have a significant impact on total operating costs. Based on comments from transit agencies, wages may need to increase $25-30 \%$. Considering increases in labor costs and possible increases in other operating costs, the impacts on funding needs resulting from a $20 \%$ operating cost increase was analyzed.

According to 2012 NTD data, as reported in the 2014 Rural Transit Fact Book, the average operating expense per mile for rural transit in North Dakota was $\$ 2.87$. A $20 \%$ increase would raise operating costs to $\$ 3.44$ per mile. Based on average 2012 NTD data for the three urban agencies, current operating costs were assumed to be $\$ 5.00$ per mile for fixed-route transit and $\$ 3.80$ per mile for demand-response service.

The number of new vehicles required to provide this additional service is uncertain, as there may be some excess capacity that already exists. It is assumed, however, that a new vehicle is required for every additional 23,000 miles of service for rural and urban demand-response transit and for every 30,000 miles for urban fixed-route service, which are the approximate averages for miles driven per vehicle per year. The cost of new vehicles is assumed by be $\$ 50,000$ for rural agencies, assuming a mix of cutaways, vans, and minivans; $\$ 450,000$ for urban fixed-route buses; and $\$ 65,000$ for urban demand-response vehicles. (Actual costs vary based on size and type of technology chosen.)

Part of the increase in fixed-route service for Bismarck-Mandan can be funded by shifting resources from the Bis-Man paratransit system, as recommended by the most recent TDP for the city. The TDP estimated that limiting paratransit service to ADA-eligible individuals in Bismarck-Mandan would provide approximately $\$ 800,000$ that could be shifted to fixed-route service. Eliminating paratransit service during hours in which the fixed-route system is not in service would provide $\$ 450,000$. Doubling the fares for non-ADA riders on the paratransit service would provide $\$ 285,000$. Bis-Man Transit could shift $\$ 500,000$ from paratransit to fixed-route service and still provide more vehicle miles of paratransit service per capita than in Fargo and Grand Forks and approximately the same number of vehicle hours per capita. Therefore, it is recommended that part of the increase in Bismarck-Mandan's fixed-route 
service would come from a $\$ 500,000$ shift in resources, reducing the estimated increase in operating expenses by that amount.

The increased dollars needed to fund these service expansions is detailed in Tables 7.6-7.8. All expenses are expressed in 2014 dollars. The increased operating expenses for fixed-route transit depicted in these tables is the revenue needed after accounting for the $\$ 500,000$ shift in funding for Bismarck-Mandan. Without this shift, increased operating expenses would be $\$ 500,000$ greater than those shown in the tables. 
Table 7.6 Estimated Increases in Operating and Vehicle Expenses for Expanded Mobility Options, Given Current Population

\begin{tabular}{|c|c|c|c|c|}
\hline & Scenario 1 & Scenario 2 & Scenario 3 & Scenario 4 \\
\hline \multicolumn{5}{|l|}{ Rural Transit } \\
\hline Increase in Vehicle Miles & 658,514 & 819,397 & $1,150,317$ & $1,287,875$ \\
\hline $\begin{array}{l}\text { Number of New Vehicles Needed to Provide } \\
\text { New Service }\end{array}$ & 29 & 36 & 51 & 56 \\
\hline Cost of New Vehicles & $\$ 1,450,000$ & $\$ 1,800,000$ & $\$ 2,550,000$ & $\$ 2,800,000$ \\
\hline $\begin{array}{l}\text { Operating Expense to Provide Additional } \\
\text { Miles with Current Operating Costs }\end{array}$ & $\$ 1,889,936$ & $\$ 2,351,669$ & $\$ 3,301,410$ & $\$ 3,696,201$ \\
\hline $\begin{array}{l}\text { Operating Expense to Provide Additional } \\
\text { Miles with } 20 \% \text { Increase in Operating Costs }\end{array}$ & $\$ 2,267,924$ & $\$ 2,822,003$ & $\$ 3,961,692$ & $\$ 4,435,441$ \\
\hline $\begin{array}{l}\text { Total Expenses with Current Operating } \\
\text { Costs }\end{array}$ & $\$ 3,339,936$ & $\$ 4,151,669$ & $\$ 5,851,410$ & $\$ 6,496,201$ \\
\hline $\begin{array}{l}\text { Total Expenses with Increased Operating } \\
\text { Costs }\end{array}$ & $\$ 3,717,924$ & $\$ 4,622,003$ & $\$ 6,511,692$ & $\$ 7,235,441$ \\
\hline \multicolumn{5}{|l|}{ Urban Fixed-Route Transit } \\
\hline Increase in Vehicle Miles & 299,051 & 299,051 & 390,236 & 482,996 \\
\hline $\begin{array}{l}\text { Number of New Vehicles Needed to Provide } \\
\text { New Service }\end{array}$ & 10 & 10 & 14 & 17 \\
\hline Cost of New Vehicles & $\$ 4,500,000$ & $\$ 4,500,000$ & $\$ 6,300,000$ & $\$ 7,650,000$ \\
\hline $\begin{array}{l}\text { Operating Expense to Provide Additional } \\
\text { Miles with Current Operating Costs }\end{array}$ & $\$ 995,255$ & $\$ 995,255$ & $\$ 1,451,181$ & $\$ 1,914,981$ \\
\hline $\begin{array}{l}\text { Operating Expense to Provide Additional } \\
\text { Miles with } 20 \% \text { Increase in Operating Costs }\end{array}$ & $\$ 1,294,305$ & $\$ 1,294,305$ & $\$ 1,841,417$ & $\$ 2,397,977$ \\
\hline $\begin{array}{l}\text { Total Expenses with Current Operating } \\
\text { Costs }\end{array}$ & $\$ 5,495,255$ & $\$ 5,495,255$ & $\$ 7,751,181$ & $\$ 9,564,981$ \\
\hline $\begin{array}{l}\text { Total Expenses with Increased Operating } \\
\text { Costs }\end{array}$ & $\$ 5,794,305$ & $\$ 5,794,305$ & $\$ 8,141,417$ & $\$ 10,047,977$ \\
\hline \multicolumn{5}{|l|}{ Urban Demand-Response Transit } \\
\hline Increase in Vehicle Miles & 0 & 0 & 0 & 83,824 \\
\hline $\begin{array}{l}\text { Number of New Vehicles Needed to Provide } \\
\text { New Service }\end{array}$ & 0 & 0 & 0 & 4 \\
\hline Cost of New Vehicles & $\$ 0$ & $\$ 0$ & $\$ 0$ & $\$ 260,000$ \\
\hline $\begin{array}{l}\text { Operating Expense to Provide Additional } \\
\text { Miles with Current Operating Costs }\end{array}$ & $\$ 0$ & $\$ 0$ & $\$ 0$ & $\$ 318,533$ \\
\hline $\begin{array}{l}\text { Operating Expense to Provide Additional } \\
\text { Miles with } 20 \% \text { Increase in Operating Costs }\end{array}$ & $\$ 0$ & $\$ 0$ & $\$ 0$ & $\$ 382,239$ \\
\hline $\begin{array}{l}\text { Total Expenses with Current Operating } \\
\text { Costs }\end{array}$ & $\$ 0$ & $\$ 0$ & $\$ 0$ & $\$ 578,533$ \\
\hline $\begin{array}{l}\text { Total Expenses with Increased Operating } \\
\text { Costs }\end{array}$ & $\$ 0$ & $\$ 0$ & \$o & $\$ 642,239$ \\
\hline
\end{tabular}


Table 7.7 Estimated Increases in Operating and Vehicle Expenses for Expanded Mobility Options, Given Projected 2020 Population

\begin{tabular}{|c|c|c|c|c|}
\hline & Scenario 1 & Scenario 2 & Scenario 3 & Scenario 4 \\
\hline \multicolumn{5}{|l|}{ Rural Transit } \\
\hline Increase in Vehicle Miles & 823,584 & $1,169,145$ & $1,642,788$ & $1,729,805$ \\
\hline $\begin{array}{l}\text { Number of New Vehicles Needed to Provide } \\
\text { New Service }\end{array}$ & 36 & 51 & 72 & 76 \\
\hline Cost of New Vehicles & $\$ 1,800,000$ & $\$ 2,550,000$ & $\$ 3,600,000$ & $\$ 3,800,000$ \\
\hline $\begin{array}{l}\text { Operating Expense to Provide Additional Miles } \\
\text { with Current Operating Costs }\end{array}$ & $\$ 2,363,687$ & $\$ 3,355,447$ & $\$ 4,714,802$ & $\$ 4,964,540$ \\
\hline $\begin{array}{l}\text { Operating Expense to Provide Additional Miles } \\
\text { with } 20 \% \text { Increase in Operating Costs }\end{array}$ & $\$ 2,836,425$ & $\$ 4,026,537$ & $\$ 5,657,762$ & $\$ 5,957,448$ \\
\hline Total Expenses with Current Operating Costs & $\$ 4,163,687$ & $\$ 5,905,447$ & $\$ 8,314,802$ & $\$ 8,764,540$ \\
\hline Total Expenses with Increased Operating Costs & $\$ 4,636,425$ & $\$ 6,576,537$ & $\$ 9,257,762$ & $\$ 9,757,448$ \\
\hline \multicolumn{5}{|l|}{ Urban Fixed-Route Transit } \\
\hline Increase in Vehicle Miles & 445,546 & 520,460 & 624,063 & 629,360 \\
\hline $\begin{array}{l}\text { Number of New Vehicles Needed to Provide } \\
\text { New Service }\end{array}$ & 15 & 18 & 21 & 21 \\
\hline Cost of New Vehicles & $\$ 6,750,000$ & $\$ 8,100,000$ & $\$ 9,450,000$ & $\$ 9,450,000$ \\
\hline $\begin{array}{l}\text { Operating Expense to Provide Additional Miles } \\
\text { with Current Operating Costs }\end{array}$ & $\$ 1,727,730$ & $\$ 2,102,298$ & $\$ 2,620,314$ & $\$ 2,646,798$ \\
\hline $\begin{array}{l}\text { Operating Expense to Provide Additional Miles } \\
\text { with } 20 \% \text { Increase in Operating Costs }\end{array}$ & $\$ 2,173,276$ & $\$ 2,622,757$ & $\$ 3,244,377$ & $\$ 3,276,157$ \\
\hline Total Expenses with Current Operating Costs & $\$ 8,477,730$ & $\$ 10,202,298$ & $\$ 12,070,314$ & $\$ 12,096,798$ \\
\hline Total Expenses with Increased Operating Costs & $\$ 8,923,276$ & $\$ 10,722,757$ & $\$ 12,694,377$ & $\$ 12,726,157$ \\
\hline \multicolumn{5}{|l|}{ Urban Demand-Response Transit } \\
\hline Increase in Vehicle Miles & 0 & 75,800 & 75,800 & 83,824 \\
\hline $\begin{array}{l}\text { Number of New Vehicles Needed to Provide } \\
\text { New Service }\end{array}$ & 0 & 4 & 4 & 4 \\
\hline Cost of New Vehicles & $\$ 0$ & $\$ 260,000$ & $\$ 260,000$ & $\$ 260,000$ \\
\hline $\begin{array}{l}\text { Operating Expense to Provide Additional Miles } \\
\text { with Current Operating Costs }\end{array}$ & $\$ 0$ & $\$ 288,040$ & $\$ 288,040$ & $\$ 318,533$ \\
\hline $\begin{array}{l}\text { Operating Expense to Provide Additional Miles } \\
\text { with } 20 \% \text { Increase in Operating Costs }\end{array}$ & $\$ 0$ & $\$ 345,648$ & $\$ 345,648$ & $\$ 382,239$ \\
\hline Total Expenses with Current Operating Costs & $\$ 0$ & $\$ 548,040$ & $\$ 548,040$ & $\$ 578,533$ \\
\hline Total Expenses with Increased Operating Costs & \$o & $\$ 605,648$ & $\$ 605,648$ & $\$ 642,239$ \\
\hline
\end{tabular}


Table 7.8 Estimated Increases in Operating and Vehicle Expenses for Expanded Mobility Options, Given Projected 2025 Population

\begin{tabular}{|c|c|c|c|c|}
\hline & Scenario 1 & Scenario 2 & Scenario 3 & Scenario 4 \\
\hline \multicolumn{5}{|l|}{ Rural Transit } \\
\hline Increase in Vehicle Miles & 891,321 & $1,341,289$ & $1,839,210$ & $1,867,312$ \\
\hline $\begin{array}{l}\text { Number of New Vehicles Needed to Provide } \\
\text { New Service }\end{array}$ & 39 & 59 & 80 & 82 \\
\hline Cost of New Vehicles & $\$ 1,950,000$ & $\$ 2,950,000$ & $\$ 4,000,000$ & $\$ 4,100,000$ \\
\hline $\begin{array}{l}\text { Operating Expense to Provide Additional Miles } \\
\text { with Current Operating Costs }\end{array}$ & $\$ 2,558,093$ & $\$ 3,849,500$ & $\$ 5,278,534$ & $\$ 5,359,186$ \\
\hline $\begin{array}{l}\text { Operating Expense to Provide Additional Miles } \\
\text { with } 20 \% \text { Increase in Operating Costs }\end{array}$ & $\$ 3,069,711$ & $\$ 4,619,400$ & $\$ 6,334,241$ & $\$ 6,431,023$ \\
\hline Total Expenses with Current Operating Costs & $\$ 4,508,093$ & $\$ 6,799,500$ & $\$ 9,278,534$ & $\$ 9,459,186$ \\
\hline Total Expenses with Increased Operating Costs & $\$ 5,019,711$ & $\$ 7,569,400$ & $\$ 10,334,241$ & $\$ 10,531,023$ \\
\hline \multicolumn{5}{|l|}{ Urban Fixed-Route Transit } \\
\hline Increase in Vehicle Miles & 660,607 & 693,719 & 806,443 & 806,443 \\
\hline $\begin{array}{l}\text { Number of New Vehicles Needed to Provide } \\
\text { New Service }\end{array}$ & 23 & 24 & 27 & 27 \\
\hline Cost of New Vehicles & $\$ 10,350,000$ & $\$ 10,800,000$ & $\$ 12,150,000$ & $\$ 12,150,000$ \\
\hline $\begin{array}{l}\text { Operating Expense to Provide Additional Miles } \\
\text { with Current Operating Costs }\end{array}$ & $\$ 2,803,037$ & $\$ 2,968,596$ & $\$ 3,532,215$ & $\$ 3,532,215$ \\
\hline $\begin{array}{l}\text { Operating Expense to Provide Additional Miles } \\
\text { with } 20 \% \text { Increase in Operating Costs }\end{array}$ & $\$ 3,463,645$ & $\$ 3,662,316$ & $\$ 4,338,659$ & $\$ 4,338,659$ \\
\hline Total Expenses with Current Operating Costs & $\$ 13,153,037$ & $\$ 13,768,596$ & $\$ 15,682,215$ & $\$ 15,682,215$ \\
\hline Total Expenses with Increased Operating Costs & $\$ 13,813,645$ & $\$ 14,462,316$ & $\$ 16,488,659$ & $\$ 16,488,659$ \\
\hline \multicolumn{5}{|l|}{ Urban Demand-Response Transit } \\
\hline Increase in Vehicle Miles & 0 & 140,136 & 140,136 & 140,136 \\
\hline $\begin{array}{l}\text { Number of New Vehicles Needed to Provide } \\
\text { New Service }\end{array}$ & 0 & 7 & 7 & 7 \\
\hline Cost of New Vehicles & $\$ 0$ & $\$ 455,000$ & $\$ 455,000$ & $\$ 455,000$ \\
\hline $\begin{array}{l}\text { Operating Expense to Provide Additional Miles } \\
\text { with Current Operating Costs }\end{array}$ & $\$ 0$ & $\$ 532,517$ & $\$ 532,517$ & $\$ 532,517$ \\
\hline $\begin{array}{l}\text { Operating Expense to Provide Additional Miles } \\
\text { with } 20 \% \text { Increase in Operating Costs }\end{array}$ & $\$ 0$ & $\$ 639,020$ & $\$ 639,020$ & $\$ 639,020$ \\
\hline Total Expenses with Current Operating Costs & $\$ 0$ & $\$ 987,517$ & $\$ 987,517$ & $\$ 987,517$ \\
\hline Total Expenses with Increased Operating Costs & \$O & $\$ 1,094,020$ & $\$ 1,094,020$ & $\$ 1,094,020$ \\
\hline
\end{tabular}


In urban areas, farebox revenue currently covers about $16 \%$ of operating expenses, while federal funds cover $35-40 \%$, state funds about $9 \%$, and local funds about $24 \%$ (with other sources accounting for the remainder), with some variations between the three agencies. Farebox revenue currently covers about $14 \%$ of operating expenses in rural areas, with local, state, and federal funds accounting for about $11 \%$, $26 \%$, and $47 \%$ of expenses, respectively. Federal funds are used for a majority of capital expenditures in the state, with the remainder largely coming from local sources. Table 7.9 shows federal funds covering $91 \%$ of capital expenses in the state in recent years, but these numbers were influenced by federal spending from the American Recovery and Reinvestment Act (ARRA). Excluding ARRA funds, the federal share of capital expenses is $80 \%$.

Table 7.9 Sources of North Dakota Transit Funding, 2009-2012

\begin{tabular}{lrrrr}
\hline & \multicolumn{2}{c}{ Rural } & \multicolumn{2}{c}{ Urban } \\
\hline Operating Expenses & & & & \\
Federal & $\$ 4,456,161$ & $47 \%$ & $\$ 17,131,707$ & $39 \%$ \\
State & $\$ 2,358,052$ & $26 \%$ & $\$ 3,954,924$ & $9 \%$ \\
Local & $\$ 1,192,456$ & $11 \%$ & $\$ 10,465,944$ & $24 \%$ \\
Fares Revenue & $\$ 1,206,608$ & $14 \%$ & $\$ 7,022,624$ & $16 \%$ \\
Other & $\$ 274,916$ & $3 \%$ & $\$ 5,678,406$ & $13 \%$ \\
Capital Expenses & & & & \\
Federal & $\$ 5,806,093$ & $91 \%$ & $\$ 14,242,120$ & $91 \%$ \\
State & $\$ 658$ & $2 \%$ & $\$ 45,703$ & $0 \%$ \\
Local & $\$ 315,943$ & $8 \%$ & $\$ 848,803$ & $5 \%$ \\
Other & & $0 \%$ & $\$ 584,636$ & $4 \%$ \\
\hline
\end{tabular}

Source: National Transit Database, 2009-2012

Note that the funding needs estimated in this section are strictly to cover the increased operating costs and new vehicles needed to provide this service. Transit agencies also have other funding needs for improving facilities and regular replacement of existing vehicles.

\subsection{Funding Needs for Vehicle Replacement}

The vehicle expenses estimated in the previous section are one-time expenses needed to increase fleet sizes across the state to allow for improved service levels. However, these vehicles will need to be replaced periodically, increasing annual capital expenditures. In addition, there currently is a significant number of vehicles in the state that have surpassed their useful lives and are in need of replacement.

The Federal Transit Administration (FTA) has defined a minimum service life for different categories of buses and vans. The minimum service life indicates the number of years or miles that transit vehicles purchased with federal funds must be in service before they can be retired without financial penalty. This minimum service life requirement is shown in Table 7.10. These requirements have become perceived as the actual useful life of these vehicles (FTA 2007). Analysis by the FTA published in 2007 showed that, on average, transit buses and vans are retired between one to three years after their minimum service-life requirement has been satisfied. The study found the average retirement age was 15.1 years for a 12 -year bus, 5.9 years for a 5 -year bus/van, and 5.6 years for a 4 -year van. 
Table 7.10 Minimum Service-Life Categories for Buses and Vans

\begin{tabular}{|c|c|c|c|c|c|}
\hline \multirow{2}{*}{ Category } & \multicolumn{3}{|c|}{ Typical Characteristics } & \multicolumn{2}{|c|}{$\begin{array}{c}\text { Minimum Life } \\
\text { (Whichever comes first) }\end{array}$} \\
\hline & Length & Approx. GVW & Seats & Years & Miles \\
\hline Heavy-Duty Large Bus & $\begin{array}{l}\text { 35-48 feet and } 60 \\
\text { feet artic. }\end{array}$ & $33,000-40,000$ & $27-40$ & 12 & 500,000 \\
\hline Heavy-Duty Small Bus & 30 feet & $26,000-33,000$ & $26-35$ & 10 & 350,000 \\
\hline $\begin{array}{l}\text { Medium-Duty and } \\
\text { Purpose-Built Bus }\end{array}$ & 30 feet & $16,000-26,000$ & $22-30$ & 7 & 200,000 \\
\hline $\begin{array}{l}\text { Light-Duty Mid-Sized } \\
\text { Bus }\end{array}$ & $25-35$ feet & $10,000-16,000$ & $16-25$ & 5 & 150,000 \\
\hline $\begin{array}{l}\text { Light-Duty Small Bus, } \\
\text { Cutaways, and } \\
\text { Modified Van }\end{array}$ & $16-28$ feet & $6,000-14,000$ & $10-22$ & 4 & 100,000 \\
\hline
\end{tabular}

Source: Federal Transit Administration (2007)

If vehicles were replaced following the minimum life requirements, then $8 \%$ (1 out of 12) of the 35 -foot to 40 -foot fixed-route buses would need to be replaced each year, on average, and $20 \%-25 \%$ of cutaways and vans would need to be replaced each year. If buses were replaced according to the average retirement ages previous cited, then $7 \%$ of fixed-route buses and $17 \%-18 \%$ of cutaways and vans would be replaced each year.

In North Dakota, 16 vehicles were funded for replacement in FY 2013, and 18 were funded for replacement in FY 2014. According to the NDDOT, there were 99 vehicles statewide as of April 2014 that had exceeded their useful lives. Of these, 42 were minivans and 57 were cutaways or larger.

MATBUS in Fargo, as of September 2014, has five 1997 35-foot, fixed-route buses and two 2006 paratransit buses that have surpassed their useful lives. Two of the fixed-route buses and both paratransit buses have already been funded for replacement. In addition, MATBUS has two 2002 29foot, fixed-route buses and five 2008 paratransit buses that are at or near replacement age. Three of those paratransit buses have already been funded for replacement. Among the vehicles at or near replacement age, five fixed-route buses and two paratransit buses have not yet been funded for replacement. The cost to replace paratransit buses is $\$ 65,000$, and MATBUS is replacing fixed-route buses with 40 -foot hybrids at a cost of $\$ 650,000$.

Grand Forks, as of September 2014, has three vehicles that have exceeded their useful lives and need to be replaced. An additional two vehicles need to be replaced in two years. Bis-Man Transit has eight paratransit vehicles from 2005 or earlier that have exceeded their useful lives, and the agency has three 30-foot, fixed-route buses from 2004 and two from 2007 in need of replacement.

Table 7.11 shows an estimate of current vehicle replacement needs statewide. The number of vehicles by type and the unit cost are estimates because it is not known what type or size of vehicle transit agencies will request as replacement for existing vehicles. The cost of fixed-route buses will vary based on size and technology used. Hybrid buses are significantly more expensive. Thirty-foot fixed-route buses are less expensive but have a shorter life span and must be replaced more often. 
Table 7.11 Estimated Current Vehicle Replacement Needs

\begin{tabular}{lcrrr}
\hline & $\begin{array}{c}\text { Number of } \\
\text { Vehicles Exceeding } \\
\text { Useful Life }\end{array}$ & Unit Cost & Total Cost & $\begin{array}{c}\text { Non-Federal } \\
\text { Share }(20 \%)^{*}\end{array}$ \\
\hline Minivans & 42 & 37,000 & $1,554,000$ & $\$ 310,800$ \\
Cutaways - Rural & 32 & 54,000 & $1,728,000$ & $\$ 345,600$ \\
Cutaways - Urban & 12 & 65,000 & 780,000 & $\$ 156,000$ \\
Fixed-Route Buses, 30-40 foot & 13 & 450,000 & $5,850,000$ & $\$ 1,170,000$ \\
Total & 99 & & $9,912,000$ & $\$ 1,982,400$
\end{tabular}

*Assumes current $80 \%$ federal share continues. However, state and local shares may need to increase to fund vehicle purchases if federal transit funding becomes stagnant.

Based on these estimates, the cost of replacing all vehicles in the state that have exceeded their useful lives would be nearly $\$ 10$ million. If federal funding covers $80 \%$ of capital costs, $\$ 1,982,400$ in non-

federal funding would be needed. However, state and local shares may need to increase to fund vehicle purchases, given that federal transit funding may become stagnant.

Estimates from the previous section showed the number of new vehicles that will need to be purchased to provide increased service. These vehicles will need to be periodically replaced. Estimates for average annual vehicle replacement costs are presented in Table 7.12, considering the current fleet as well as the new vehicles. All costs are expressed in 2014 dollars. Given the current fleet and estimates for average life and unit costs, an average of 51 vehicles would need to be replaced each year at a cost of $\$ 3.9$ million. With the additional vehicles required for Scenario 2, assuming 2020 population projections, an additional 11 vehicles would need to be replaced each year in the long-run at an additional cost of $\$ 1.0$ million. Total vehicle replacement costs would average $\$ 5.0$ million per year. Of this total, $\$ 1.0$ million would need to come from non-federal sources if the current federal share continues. If that share changes, state and local shares may need to increase. 
Table 7.12 Long-Term Annual Average Vehicle Replacement Costs

\begin{tabular}{|c|c|c|c|c|c|c|}
\hline & $\begin{array}{c}\text { Number } \\
\text { of } \\
\text { Vehicles }\end{array}$ & Unit Cost & $\begin{array}{c}\text { Average } \\
\text { Life (years) }\end{array}$ & $\begin{array}{l}\text { Number } \\
\text { Replaced } \\
\text { Annually }\end{array}$ & $\begin{array}{c}\text { Average } \\
\text { Annual } \\
\text { Cost }\end{array}$ & $\begin{array}{c}\text { Non-Federal } \\
\text { Share } \\
(20 \%)^{*} \\
\end{array}$ \\
\hline \multicolumn{7}{|l|}{ Current Fleet } \\
\hline Vans/Minivans & 111 & $\$ 37,000$ & 5.6 & 20 & $\$ 733,393$ & $\$ 146,679$ \\
\hline Cutaways - Rural & 103 & $\$ 54,000$ & 5.9 & 17 & $\$ 942,712$ & $\$ 188,542$ \\
\hline Cutaways - Urban & 59 & $\$ 65,000$ & 5.9 & 10 & $\$ 650,000$ & $\$ 130,000$ \\
\hline Fixed-Route Buses, 30-40 foot & 50 & $\$ 450,000$ & 14 & 4 & $\$ 1,607,143$ & $\$ 321,429$ \\
\hline Subtotal & 323 & & & 51 & $\$ 3,933,248$ & $\$ 786,650$ \\
\hline \multicolumn{7}{|c|}{ Additional Vehicles (assuming Scenario 2 with 2020 population) } \\
\hline Vans/Minivans & 26 & $\$ 37,000$ & 5.6 & 5 & $\$ 174,781$ & $\$ 34,956$ \\
\hline Cutaways - Rural & 25 & $\$ 54,000$ & 5.9 & 4 & $\$ 224,665$ & $\$ 44,933$ \\
\hline Cutaways - Urban & 4 & $\$ 65,000$ & 5.9 & 1 & $\$ 44,068$ & $\$ 8,814$ \\
\hline Fixed-Route Buses, 30-40 foot & 18 & $\$ 450,000$ & 14 & 1 & $\$ 578,571$ & $\$ 115,714$ \\
\hline Subtotal & 73 & & & 11 & $\$ 1,022,085$ & $\$ 204,417$ \\
\hline Total & 396 & & & 62 & $\$ 4,955,332$ & $\$ 991,066$ \\
\hline
\end{tabular}

*Assumes current $80 \%$ federal share continues. However, state and local shares may need to increase to fund vehicle purchases if federal transit funding becomes stagnant. 


\section{CONCLUSIONS AND RECOMMENDATIONS}

\subsection{Expansion of Services}

Because of population growth and current unmet needs, there is demand for expansion of services in the western part of the state. Unmet needs exist in other parts of the state as well.

Minot/Souris Basin Region: Minot currently has fixed-route service five days a week with no weekend or evening service. Kenmare Wheels and Meals provides service seven days a week in the town of Kenmare. Souris Basin Transportation provides demand-response service seven days a week in Minot, five days a week in Rugby, four days a week in Bottineau, and weekly service throughout most of the surrounding area.

Survey responses and analysis of current service levels, along with projected population growth, suggest a need for service expansion in this region. The Souris Basin Transportation director noted that more than $10 \%$ of trip requests are turned down because of lack of capacity, and both he and the Minot City Transit superintendent said that transportation needs of the residents in their service area are poorly being met. Both noted a need for an expansion of Minot's fixed-route system, including longer hours of service and weekend service, and a major need for more services for work trips. Responses from human service agencies also reflected the need for increased service in this region. In rural areas, service is limited because of a lack of drivers.

Analysis of service levels in the region also shows vehicles miles per capita, vehicle hours per capita, and vehicles per capita are below the benchmark levels, although trips per capita exceeds the benchmark. Furthermore, this region has experienced significant growth in recent years which is expected to continue over the next decade.

Recommendations:

Expand fixed-route service in Minot to provide more hours of service and some weekend service.

Expand service in rural areas to multiple days per week.

Williston/Northwest Region: This is the fastest-growing region in the state and has significant needs for increased transit services. While span of service is provided at a high level, trips provided, vehicle miles, and vehicles available per capita are all below benchmark levels, suggesting that an expansion of services is warranted. Because of its growing population, demand in Williston may be great enough to support a fixed-route system. The transit coordinator in the city mentioned a need for fixed-route service.

Recommendations:

Expand demand-response service in Williston to seven days a week and increase hours of service. Study the addition of fixed-route service for Williston. 


\section{Add vehicles and staff to meet growing demand.}

Dickinson/Stark County: Dickinson is another city experiencing significant population growth. The demand-response system in the city provides a high level of service, as measured by its span of service, with service available seven days a week and more than 15 hours per day (6:45 a.m. to 10:00 p.m.). Service in the rural areas of the county is limited based on driver availability. Although demand-response level of service is high, trips provided, vehicle miles, and vehicles in service per capita for the county are below the national averages, suggesting a need for additional service and possibly fixed-route service. The city has become large enough to study the possibility of adding a fixed-route system. The transit director in Dickinson mentioned the need for fixed-route service, and the agency has received a federal planning grant and is beginning the process.

Recommendations:

Add vehicles and staff to meet growing demand.

Study the addition of fixed-route service.

West River: Service is available at least three days a week throughout the West River region, including some counties with service five or seven days a week. Hours of service are limited, at less than nine hours per day throughout the region. This region has among the lowest trips, vehicle miles, vehicle hours, and vehicles in service per capita in the state, suggesting an expansion of services is warranted. The West River Transit director mentioned a need for weekend service and commented that lack of available drivers is the main limiting factor.

Recommendations:

Add vehicles and staff to meet demand.

Increase days and hours of service.

Bismarck-Mandan: Bismarck-Mandan operates a high level of service for its demand-response system, running 24/7. The fixed-route system, however, provides a below-average number of trips and vehicle miles per capita, when compared to other cities its size. The current level of fixed-route rides per capita is very low. Other performance measures for the fixed-route system, such as trips per vehicle mile, trips per vehicle hour, passenger miles per vehicle mile, and operating cost per trip are poor compared to Fargo, Grand Forks, and other cities of its size. As noted in the Transit Development Plan (TDP), Bis-Man Transit devotes a lower percentage of its funding to fixed-route service compared to agencies in similarly-sized cities.

Bis-Man Transit was a demand-response system that began providing fixed-route service in 2004 . The demand-response service, instead of operating as an ADA complementary paratransit service, continues to provide a high level of service, being available to anyone aged 60 or older. Shifting resources from paratransit to the fixed-route system, as recommended by the TDP, would allow quality of service to 
improve for the fixed-route system and would likely have a positive impact on its performance measures.

As the city continues to grow, it will need to further expand its fixed-route system by increasing service frequency, span, and coverage. Expanding the fixed-route system would also reduce pressure on the demand-response service.

This study recommends increases in fixed-route services to allow for vehicle miles and/or vehicle hours of service per capita to reach the benchmark values. Some of the funding for these increases would come from a shift in resources from paratransit to fixed-route. If fixed-route quality of service improves and riders are encouraged to shift from paratransit to fixed-route, ridership per capita and other performance measures should improve as well.

Recommendations:

Expand fixed-route service by increasing service frequency and span of service.

Implement recommendations from the Transit Development Plan.

Shift resources from the paratransit system to the fixed-route system.

Fargo-West Fargo: The Fargo metro area has experienced significant growth, which is expected to continue, and as a result the need for transit service continues to increase. The LRTP recommends, as a minimum vision, that growth in transit service hours and service miles be equal to or greater than population growth. That growth should come through expanded coverage, increased frequency, or extended service hours. While MATBUS has implemented a number of service improvements since its most recent TDP, some recommendations for increased service have yet to be added. Furthermore, the construction of a new Sanford hospital in Fargo, scheduled to open in fall 2017, will create a need for new service. The next major priority for Fargo transit is to add a new route to serve this hospital.

There may also be unmet demand for demand-response service in the city. The director of HandiWheels, a demand-response provider in the city, noted that $5-10 \%$ of their trip requests are turned down because of lack of capacity, that there is a major need for many types of trips, and that the transportation needs of the people they serve are being poorly met.

Recommendations:

Allow for service increases (improved frequency, coverage, and span of service) to serve the growing population. 
Grand Forks: The greatest needs for Grand Forks include facility improvements, vehicle replacement, and service improvements as the city grows. The current facility is in need of major renovation and rehab at a cost of $\$ 9.5$ million.

Recommendations:

Address needs for facility improvements.

Allow for service improvements as the city grows.

Rural Red River Valley: For most of this region, service is available at least three days a week and 9-12 hours per day, but measures of service per capita show a need for more service. Like the West River region, the rural Red River Valley region has among the lowest number of trips, vehicle miles, vehicle hours, and vehicles in service per capita in the state.

Recommendations:

Increase days and hours of service and add vehicles and staff.

Other: Service levels should also increase in other areas that do not meet the benchmark levels of service, have insufficient span of service, or are experiencing sufficient population growth or growth in the older adult population. Some areas, such as the South Central and James River areas and Kidder County, are meeting the target levels of service and are not projected to experience overall population growth. However, these areas are experiencing demographic shifts that are resulting in a growing older adult population which increases the need for service. Other areas, such as Rolette and Sioux counties are also experiencing significant growth in the older adult population.

Recommendations:

Provide at least three days per week of service in all areas of the state.

Increase service hours to a minimum of nine hours per day.

Increase services in areas with a growing senior population. 


\subsection{Staffing Needs}

A major finding from the study is the need to improve staffing capabilities. About half of the transit agencies reported having inadequate staff to meet current needs, and most indicated staff is inadequate to meet expected future needs within the next five years. Many agencies across the state mentioned difficulties in finding enough qualified staff, especially drivers. This is especially true in the western part of the state, where agencies compete with the oil industry and private companies for employees. Many agencies also have an aging staff that is nearing retirement. Attracting and retaining a qualified staff to maintain current levels of service and then to increase service to desired levels will require more funding for salaries and benefits. Wages for drivers and other staff will need to increase.

Recommendations:

Increase operating funding for employee wages.

\subsection{Facilities and Vehicle Needs}

Meeting the demand for increased service will require an increase in the number of vehicles in operation. Many agencies mentioned a need for more vehicles. The number of new vehicles and the corresponding costs needed for each of the expansion scenarios were detailed in Tables 7.6-7.8. Vehicle replacement needs were estimated in Tables 7.11-7.12.

Many transit agencies also need upgraded vehicles storage facilities. Nine out of 23 responding agencies reported that vehicle storage facilities are inadequate for current needs, and an additional six reported that their facilities are inadequate for expected needs within the next five years.

Recommendations:

Increase funding for vehicles to provide transit agencies the capacity to increase service levels and meet the growing demand. New vehicles should be ADA accessible.

Provide funding to upgrade vehicle storage facilities and for other facility needs.

Develop a framework for estimating future facility needs and require each system receiving funds to conduct a 3-5 year capital plan that would include an analysis of facility needs. 


\subsection{Recommended Funding Increases}

Table 8.1 provides a summary of the increased operating and new vehicle expenses estimated in each of the scenarios. These estimates assume a $20 \%$ increase in operating costs. Note that the operating expenses are ongoing annual expenses, while the vehicle purchases are one-time costs. If all additional services are added in the first year, then the needed revenue for the year would equal the new operating costs plus the vehicle purchase costs. In subsequent years, however, the necessary revenue increase is represented by the increased operating costs.

The estimates in Table 8.1 are total required revenues without consideration of funding source. As noted in Table 7.9, federal funds in recent years have accounted for $47 \%$ and $39 \%$ of rural and urban operating expenses, respectively. Federal funds cover $80 \%$ of capital expenses. Tables $8.2-8.5$ show the state and local funding required for expanded transit service assuming federal, state, and local shares remain the same. These estimates are for the 2020 projected population scenarios, accounting for likely population growth. The table assumes the federal government's share of increased funding equals its current share of funding, but in reality, state and local shares may need to increase to fund expanded transit services if federal transit funding becomes stagnant.

Scenario 2 is the least costly scenario that meets the most basic transit needs. It adds service in areas that are not meeting any of the benchmark values or have low levels of service as measured by days and hours of service, and it also ensures that transit services will increase at a rate equal to or greater than population growth and that areas experiencing growth in the older adult population will be able to improve service. Justification can also be made for Scenarios 3 and 4, as there are needs for additional services throughout the state. It is recommended that funding needs take into consideration increased operating costs, which are needed to allow for wage increases. It is also recommended that 2020 population projections are considered, so transit agencies can meet the demand from increased population growth over the next five years.

Better estimates could be obtained if sketch planning was conducted for each system in the state, especially those described in more detail in Section 8.1. Without that level of analysis, however, the calculations presented in this study provide useful estimates of the need for increased transit service and funding levels to meet the mobility needs of the state's residents. 
Table 8.1 Summary of Estimated Increase in Expenses for Expanded Mobility Options

\begin{tabular}{|c|c|c|c|c|}
\hline & Scenario 1 & Scenario 2 & Scenario 3 & Scenario 4 \\
\hline \multicolumn{5}{|l|}{ Rural Transit } \\
\hline \multicolumn{5}{|l|}{ Current population } \\
\hline Annual operating expense & $\$ 2,267,924$ & $\$ 2,822,003$ & $\$ 3,961,692$ & $\$ 4,435,441$ \\
\hline Vehicle expense & $\$ 1,450,000$ & $\$ 1,800,000$ & $\$ 2,550,000$ & $\$ 2,800,000$ \\
\hline \multicolumn{5}{|l|}{ Projected 2020 population } \\
\hline Annual operating expense & $\$ 2,836,425$ & $\$ 4,026,537$ & $\$ 5,657,762$ & $\$ 5,957,448$ \\
\hline Vehicle expense & $\$ 1,800,000$ & $\$ 2,550,000$ & $\$ 3,600,000$ & $\$ 3,800,000$ \\
\hline \multicolumn{5}{|l|}{ Projected 2025 population } \\
\hline Annual operating expense & $\$ 3,069,711$ & $\$ 4,619,400$ & $\$ 6,334,241$ & $\$ 6,431,023$ \\
\hline Vehicle expense & $\$ 1,950,000$ & $\$ 2,950,000$ & $\$ 4,000,000$ & $\$ 4,100,000$ \\
\hline \multicolumn{5}{|l|}{ Urban Fixed-Route Transit } \\
\hline \multicolumn{5}{|l|}{ Current population } \\
\hline Annual operating expense & $\$ 1,294,305$ & $\$ 1,294,305$ & $\$ 1,841,417$ & $\$ 2,397,977$ \\
\hline Vehicle expense & $\$ 4,500,000$ & $\$ 4,500,000$ & $\$ 6,300,000$ & $\$ 7,650,000$ \\
\hline \multicolumn{5}{|l|}{ Projected 2020 population } \\
\hline Annual operating expense & $\$ 2,173,276$ & $\$ 2,622,757$ & $\$ 3,244,377$ & $\$ 3,276,157$ \\
\hline Vehicle expense & $\$ 6,750,000$ & $\$ 8,100,000$ & $\$ 9,450,000$ & $\$ 9,450,000$ \\
\hline \multicolumn{5}{|l|}{ Projected 2025 population } \\
\hline Annual operating expense & $\$ 3,463,645$ & $\$ 3,662,316$ & $\$ 4,338,659$ & $\$ 4,338,659$ \\
\hline Vehicle expense & $\$ 10,350,000$ & $\$ 10,800,000$ & $\$ 12,150,000$ & $\$ 12,150,000$ \\
\hline
\end{tabular}

Urban Demand-Response Transit

Current population

\begin{tabular}{llrrr} 
Annual operating expense & $\$ 0$ & $\$ 0$ & $\$ 0$ & $\$ 382,239$ \\
Vehicle expense & $\$ 0$ & $\$ 0$ & $\$ 0$ & $\$ 260,000$ \\
ected 2020 population & & & & \\
Annual operating expense & $\$ 0$ & $\$ 345,648$ & $\$ 345,648$ & $\$ 382,239$ \\
Vehicle expense & $\$ 0$ & $\$ 260,000$ & $\$ 260,000$ & $\$ 260,000$ \\
ected 2025 population & & & & \\
Annual operating expense & $\$ 0$ & $\$ 639,020$ & $\$ 639,020$ & $\$ 639,020$ \\
Vehicle expense & $\$ 0$ & $\$ 455,000$ & $\$ 455,000$ & $\$ 455,000$ \\
\hline
\end{tabular}

\section{Total Transit}

Current population

$\begin{array}{llllr}\text { Annual operating expense } & \$ 3,562,229 & \$ 4,116,308 & \$ 5,803,109 & \$ 7,215,658 \\ \text { Vehicle expense } & \$ 5,950,000 & \$ 6,300,000 & \$ 8,850,000 & \$ 10,710,000\end{array}$

Projected 2020 population

Annual operating expense

$\$ 5,009,701 \quad \$ 6,994,942 \quad \$ 9,247,787 \quad \$ 9,615,844$

Vehicle expense

$\$ 8,550,000 \quad \$ 10,910,000 \quad \$ 13,310,000 \quad \$ 13,510,000$

Projected 2025 population

Annual operating expense

$\$ 6,533,356 \quad \$ 8,920,736 \quad \$ 11,311,920 \quad \$ 11,408,702$

Vehicle expense

$\$ 12,300,000 \$ 14,205,000 \quad \$ 16,605,000 \quad \$ 16,705,000$


Table 8.2 Rural Transit: Estimated Increase in Operating and Vehicle Expenses by Funding Source for 2020 Projected Population Scenarios, Assuming Current Funding Shares*

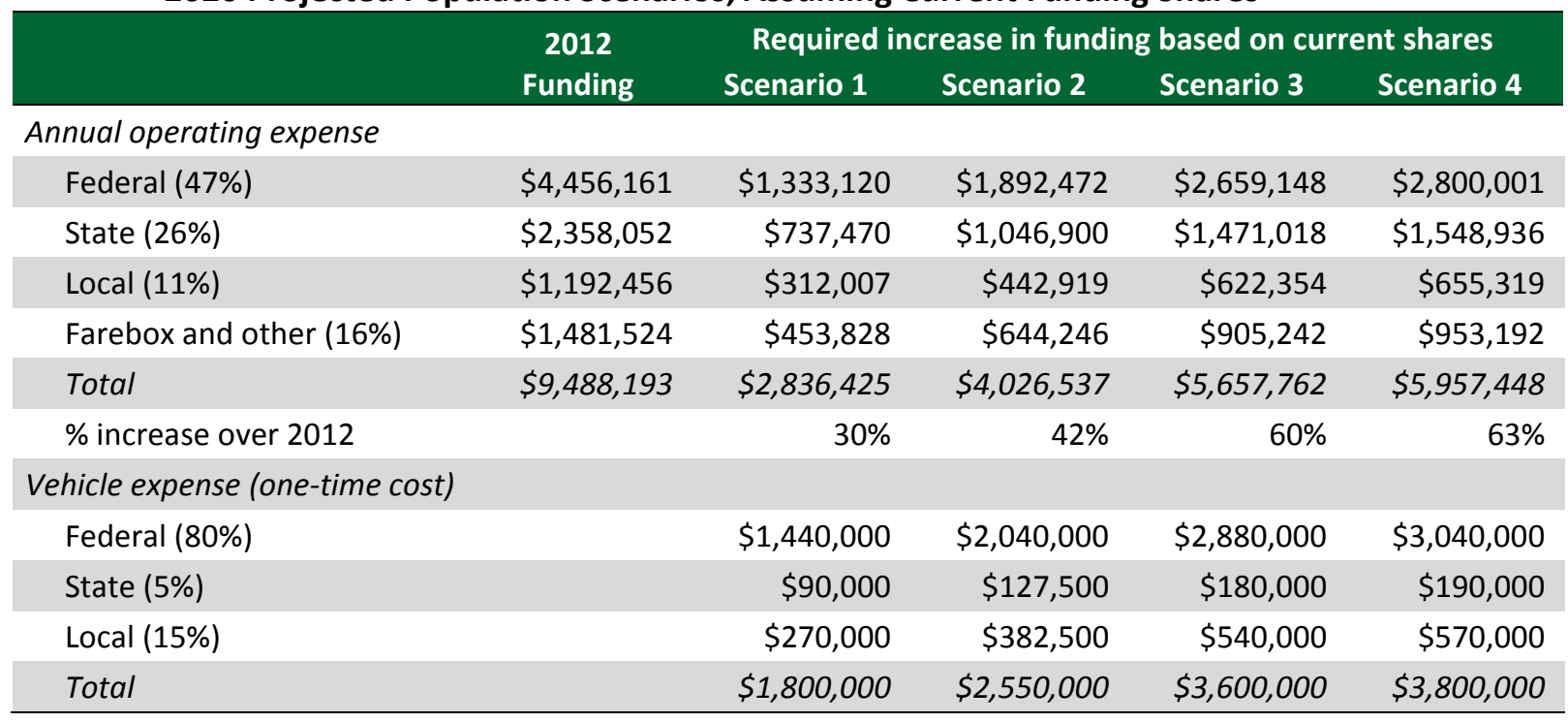

* The table assumes the federal government's share of increased funding equals its current share of funding, but in reality, state and local shares may need to increase to fund expanded transit services if federal transit funding becomes stagnant.

Table 8.3 Urban Fixed-Route Transit: Estimated Increase in Operating and Vehicle Expenses by Funding Source for 2020 Projected Population Scenarios, Assuming Current Funding Shares*

\begin{tabular}{|c|c|c|c|c|c|}
\hline & \multirow{2}{*}{$\begin{array}{c}2012 \\
\text { Funding }\end{array}$} & \multicolumn{4}{|c|}{ Required increase in funding based on current shares } \\
\hline & & Scenario 1 & Scenario 2 & Scenario 3 & Scenario 4 \\
\hline \multicolumn{6}{|l|}{ Annual operating expense } \\
\hline Federal (39\%) & $\$ 11,439,366$ & $\$ 847,578$ & $\$ 1,022,875$ & $\$ 1,265,307$ & $\$ 1,277,701$ \\
\hline State (9\%) & $\$ 2,640,824$ & $\$ 195,595$ & $\$ 236,048$ & $\$ 291,994$ & $\$ 294,854$ \\
\hline Local (24\%) & $\$ 6,988,431$ & $\$ 521,586$ & $\$ 629,462$ & $\$ 778,651$ & $\$ 786,278$ \\
\hline Farebox and other (28\%) & $\$ 8,480,867$ & $\$ 608,517$ & $\$ 734,372$ & $\$ 908,426$ & $\$ 917,324$ \\
\hline Total & $\$ 29,549,488$ & $\$ 2,173,276$ & $\$ 2,622,757$ & $\$ 3,244,377$ & $\$ 3,276,157$ \\
\hline \% increase over 2012 & & $7 \%$ & $9 \%$ & $11 \%$ & $11 \%$ \\
\hline \multicolumn{6}{|c|}{ Vehicle expense (one-time cost) } \\
\hline Federal (80\%) & & $\$ 5,400,000$ & $\$ 6,480,000$ & $\$ 7,560,000$ & $\$ 7,560,000$ \\
\hline State (1\%) & & $\$ 67,500$ & $\$ 81,000$ & $\$ 94,500$ & $\$ 94,500$ \\
\hline Local (11\%) & & $\$ 742,500$ & $\$ 891,000$ & $\$ 1,039,500$ & $\$ 1,039,500$ \\
\hline Other (8\%) & & $\$ 540,000$ & $\$ 648,000$ & $\$ 756,000$ & $\$ 756,000$ \\
\hline Total & & $\$ 6,750,000$ & $\$ 8,100,000$ & $\$ 9,450,000$ & $\$ 9,450,000$ \\
\hline
\end{tabular}

* The table assumes the federal government's share of increased funding equals its current share of funding, but in reality, state and local shares may need to increase to fund expanded transit services if federal transit funding becomes stagnant. 
Table 8.4 Urban Demand-Response Transit: Estimated Increase in Operating and Vehicle Expenses by Funding Source for $\mathbf{2 0 2 0}$ Projected Population Scenarios, Assuming Current Funding Shares*

\begin{tabular}{|lrrrrr} 
& 2012 & \multicolumn{4}{c}{ Required increase in funding based on current shares } \\
& Funding & Scenario 1 & Scenario 2 & Scenario 3 & Scenario 4 \\
\hline Annual operating expense & & & & & \\
\hline Federal (39\%) & $\$ 5,692,341$ & $\$ 0$ & $\$ 134,803$ & $\$ 134,803$ & $\$ 149,073$ \\
\hline State (9\%) & $\$ 1,314,100$ & $\$ 0$ & $\$ 31,108$ & $\$ 31,108$ & $\$ 34,402$ \\
\hline Local (24\%) & $\$ 3,477,513$ & $\$ 0$ & $\$ 82,956$ & $\$ 82,956$ & $\$ 91,737$ \\
\hline Farebox and other (28\%) & $\$ 4,220,163$ & $\$ 0$ & $\$ 96,781$ & $\$ 96,781$ & $\$ 107,027$ \\
\hline Total & $\$ 14,704,117$ & $\$ 0$ & $\$ 345,648$ & $\$ 345,648$ & $\$ 382,239$ \\
\hline increase over 2012 & & $0 \%$ & $2 \%$ & $2 \%$ & $3 \%$ \\
\hline Vehicle expense (one-time cost) & & & & & \\
\hline Federal (80\%) & & $\$ 0$ & $\$ 208,000$ & $\$ 208,000$ & $\$ 208,000$ \\
\hline State (1\%) & & $\$ 0$ & $\$ 2,600$ & $\$ 2,600$ & $\$ 2,600$ \\
\hline Local (11\%) & $\$ 0$ & $\$ 28,600$ & $\$ 28,600$ & $\$ 28,600$ \\
\hline Other (8\%) & & $\$ 0$ & $\$ 20,800$ & $\$ 20,800$ & $\$ 20,800$ \\
\hline Total & & $\$ 0$ & $\$ 260,000$ & $\$ 260,000$ & $\$ 260,000$ \\
\hline
\end{tabular}

* The table assumes the federal government's share of increased funding equals its current share of funding, but in reality, state and local shares may need to increase to fund expanded transit services if federal transit funding becomes stagnant.

Table 8.5 Total Rural and Urban Transit: Estimated Increase in Operating and Vehicle Expenses by Funding Source for 2020 Projected Population Scenarios, Assuming Current Funding Shares*

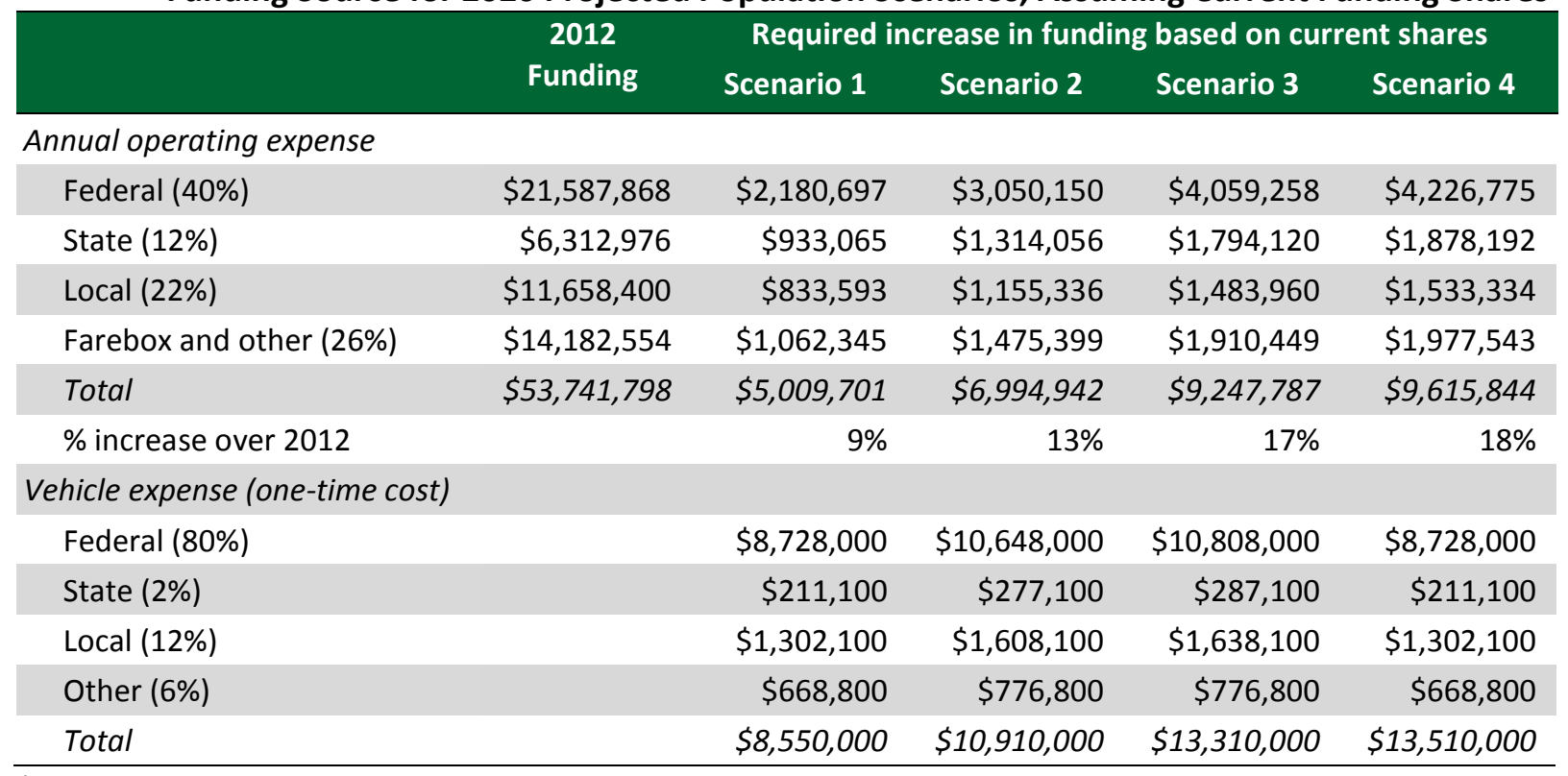

* The table assumes the federal government's share of increased funding equals its current share of funding, but in reality, state and local shares may need to increase to fund expanded transit services if federal transit funding becomes stagnant. 
Estimated vehicle expenses are one-time costs needed to increase fleet sizes across the state to allow for improved service levels. However, these vehicles will need to be replaced periodically, increasing annual capital expenditures. In addition, there currently is a significant number of vehicles in the state that have surpassed their useful lives and are in need of replacement.

Table 8.6 provides an estimate of the number of vehicles that will need to be replaced annually, on average, and the estimated cost of replacement. The table considers the current fleet, additional vehicles required under Scenario 2 assuming 2020 population, and the combined total. These are costs to be incurred in addition to the annual operating cost increases and new vehicle costs summarized in the previous tables.

Table 8.6 Estimated Long-Term Annual Vehicle Replacement Costs

\begin{tabular}{lccr}
\hline & $\begin{array}{c}\text { Number } \\
\text { Replaced } \\
\text { Annually }\end{array}$ & $\begin{array}{c}\text { Average } \\
\text { Annual Cost }\end{array}$ & $\begin{array}{c}\text { Non-Federal } \\
\text { Share }(20 \%)^{*}\end{array}$ \\
\hline Current Fleet & 51 & $\$ 3,933,248$ & $\$ 786,650$ \\
Additional Vehicles & 11 & $\$ 1,022,085$ & $\$ 204,417$ \\
Total & 62 & $\$ 4,955,332$ & $\$ 991,066$ \\
\hline
\end{tabular}

*Assumes current $80 \%$ federal share continues. However, state and local shares may need to increase to fund vehicle purchases if federal transit funding becomes stagnant.

Lastly, there are also significant needs for facility improvements across the state, as documented in Table 6.1. This study does not provide a cost estimate of needed statewide facility upgrades, and prioritizing these projects is beyond the scope of this study. The NDDOT may need to provide guidelines or guidance to transit agencies regarding vehicle storage or maintenance facilities to help identify which projects are most likely to be funded.

\subsection{Complementary Research}

Because of rapid growth in the western part of state and the resulting challenges for transportation, additional study of this region is warranted. To that end, SURTC is currently studying impacts of the region's oil boom on livability, analyzing issues such as transportation mode choice, affordable housing, and the sustainability of existing communities. The study will also examine how the oil boom has impacted local transit services and will explore changes to various modes of transportation in the region.

In another SURTC project, staff members are analyzing demand for intercity bus transportation in the state. Survey results indicated a need for more intercity, or out-of-town, transit service. This research will develop a model to estimate demand for intercity transit services throughout the state.

Additional attention should be given to the projected increase in the senior population across the state. Although parts of the state are projected to have stagnant or declining populations, the population of older adults is expected to increase in many of these areas. This aging population creates additional mobility needs that should be studied further and taken into consideration. 


\section{REFERENCES}

Bismarck Community Development Department 2014. "2010-2040 Metropolitan Population Projections." 2014. http://www.bismarck.org/DocumentCenter/View/21980 (accessed October 2014).

Bismarck-Mandan Metropolitan Planning Organization. "Mobility 2017: Transit Roadmap for Bismarck and Mandan." 2012.

Center for Social Research. North Dakota Statewide Housing Assessment Resource Project. 2012. http://www.ndsu.edu/sdc/sharp/population.php (accessed June 2014).

Fargo-Moorhead Metropolitan Council of Governments. "Metro 2040: Mobility for the Future, 2014 Update to the Long Range Transportation Plan." Fargo, ND, 2014.

Fargo-Moorhead Metropolitan Council of Governments. "Metropolitan Profile 2014: Annual Transportation Surveillance and Monitoring Report." 2014.

Fargo-Moorhead Metropolitan Council of Governments. "Transit Development Plan: 2012-2016." Fargo, ND, 2012.

Federal Transit Administration, U.S. Department of Transportation. National Transit Database. 20032012. http://www.ntdprogram.gov/ntdprogram/data.htm (accessed June 2014).

Federal Transit Administration, U.S. Department of Transportation. "Useful Life of Transit Buses and Vans." 2007.

Godavarthy, Ranjit, Jeremy Mattson, and Elvis Ndembe. Cost-Benefit Analysis of Rural and Small Urban Transit. National Center for Transit Research, University of South Florida, 2014.

Grand Forks-East Grand Forks Metropolitan Planning Organization. "2040 Update to the Long Range Transportation Plan." 2013.

Grand Forks-East Grand Forks Metropolitan Planning Organization. "Transit Development Plan." 2012.

Kittelson \& Associates, Inc., KFH Group, Inc., Parsons Brinckerhoff Quade \& Douglass, Inc., and Katherine Hunter-Zaworski. TCRP Report 100: Transit Capacity and Quality of Service Manual 2nd Edition. Transit Cooperative Research Program, Washington, DC: Transportation Research Board, 2003.

Kittelson \& Associates, Inc., Parsons Brinckerhoff, KFH Group, Inc., Texas A\&M Transportation Institute, and ARUP. TCRP Report 165: Transit Capacity and Quality of Service Manual Third Edition. Transit Cooperative Research Program, Washington, DC: Transportation Research Board, 2013.

Mattson, Jeremy. "2014 Rural Transit Fact Book." Report No. 21177060-NCTR-NDSU04, National Center for Transit Research, 2014. 
Mattson, Jeremy. "North Dakota Transportation Survey: Aging and Mobility." UGPTI Departmental Publication No. 221, Upper Great Plains Transportation Institute, North Dakota State University, Fargo, ND, 2009.

Mattson, Jeremy, and David Ripplinger. Marginal Cost Pricing and Subsidy of Transit in Small Urban Areas. MPC-11-241, Upper Great Plains Transportation Institute, North Dakota State University, Fargo: Mountain-Plains Consortium, 2011.

Mattson, Jeremy, Jill Hough, and Al Abeson. "Assessing Existing and Needed Community Transportation for People with Disabilities in North Dakota." Department Publication No. 231, Upper Great Plains Transportation Institute, North Dakota State University, 2010.

Mielke, Jon, Jim Miller, David Ripplinger, Del Peterson, and Jill Hough. "Personal Mobility in North Dakota: Trends, Gaps, and Recommended Enhancements." Departmental Report No. 165, Upper Great Plains Transportation Institute, North Dakota State University, 2005.

Peterson, Del. "Improving Veteran Mobility in Small Urban and Rural Areas." National Center for Transit Research, University of South Florida, Tampa, 2014.

U.S. Census Bureau. 2008-2012 American Community Survey 5-Year Estimates. n.d. http://factfinder2.census.gov (accessed June 2014). 


\section{APPENDIX A. PROJECT STEERING COMMITTEE}

$\begin{array}{ll}\text { Name } & \text { Organization } \\ \text { Adam Altenburg } & \text { Fargo-Moorhead Metro COG } \\ \text { Dale Bergman } & \text { Cities Area Transit } \\ \text { Julie Bommelman } & \text { Metro Area Transit } \\ \text { Janis Cheney } & \text { AARP North Dakota } \\ \text { Darrell Francis } & \text { Souris Basin Transportation } \\ \text { Paul Grindeland } & \text { Valley Senior Services } \\ \text { Pat Hansen } & \text { South Central Adult Services } \\ \text { Becky Hanson } & \text { North Dakota Department of Transportation } \\ \text { Stacey Hanson } & \text { North Dakota Department of Transportation } \\ \text { Colleen Rodakowski } & \text { Elder Care } \\ \text { Steve Saunders } & \text { Bismarck-Mandan MPO } \\ \text { Robin Werre } & \text { Bis-Man Transit }\end{array}$




\section{APPENDIX B. POPULATION DENSITY MAPS}

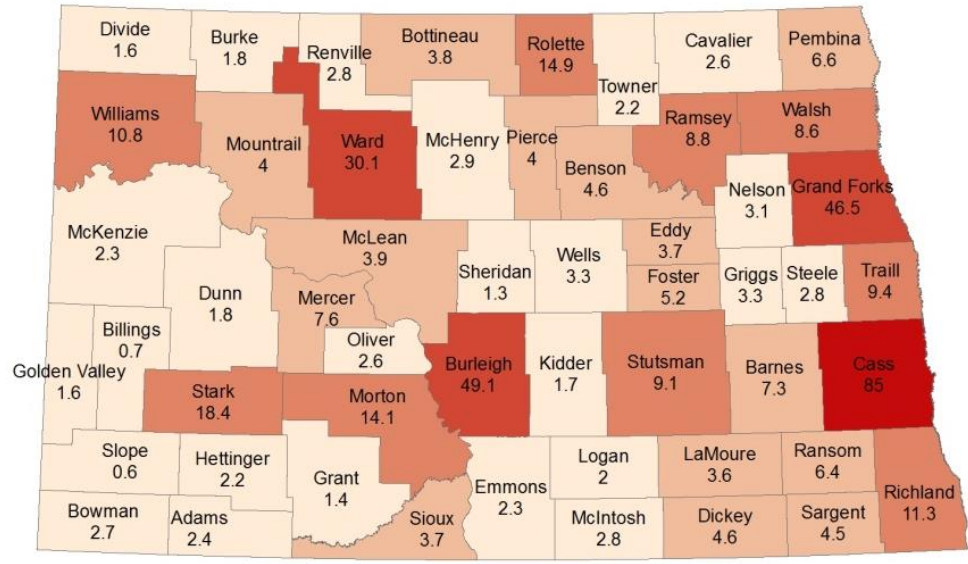

Population per Square Mile

\begin{tabular}{|l|l|}
\hline & $0.6-3.3$ \\
\hline & $3.4-7.6$ \\
& $7.7-18.4$ \\
& $18.5-49.1$ \\
\hline & $49.2-85.0$ \\
\hline
\end{tabular}

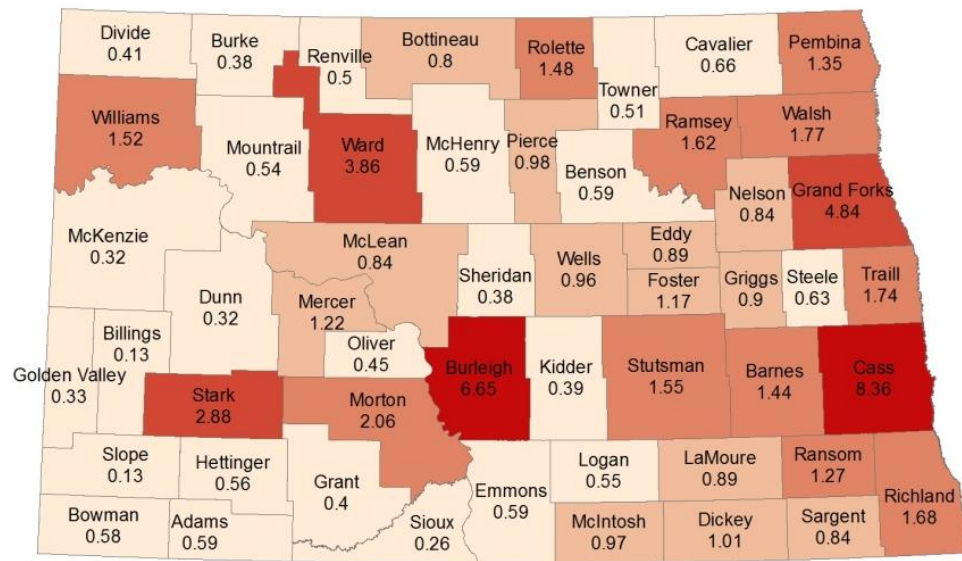

Population 65 or Older per Square Mile
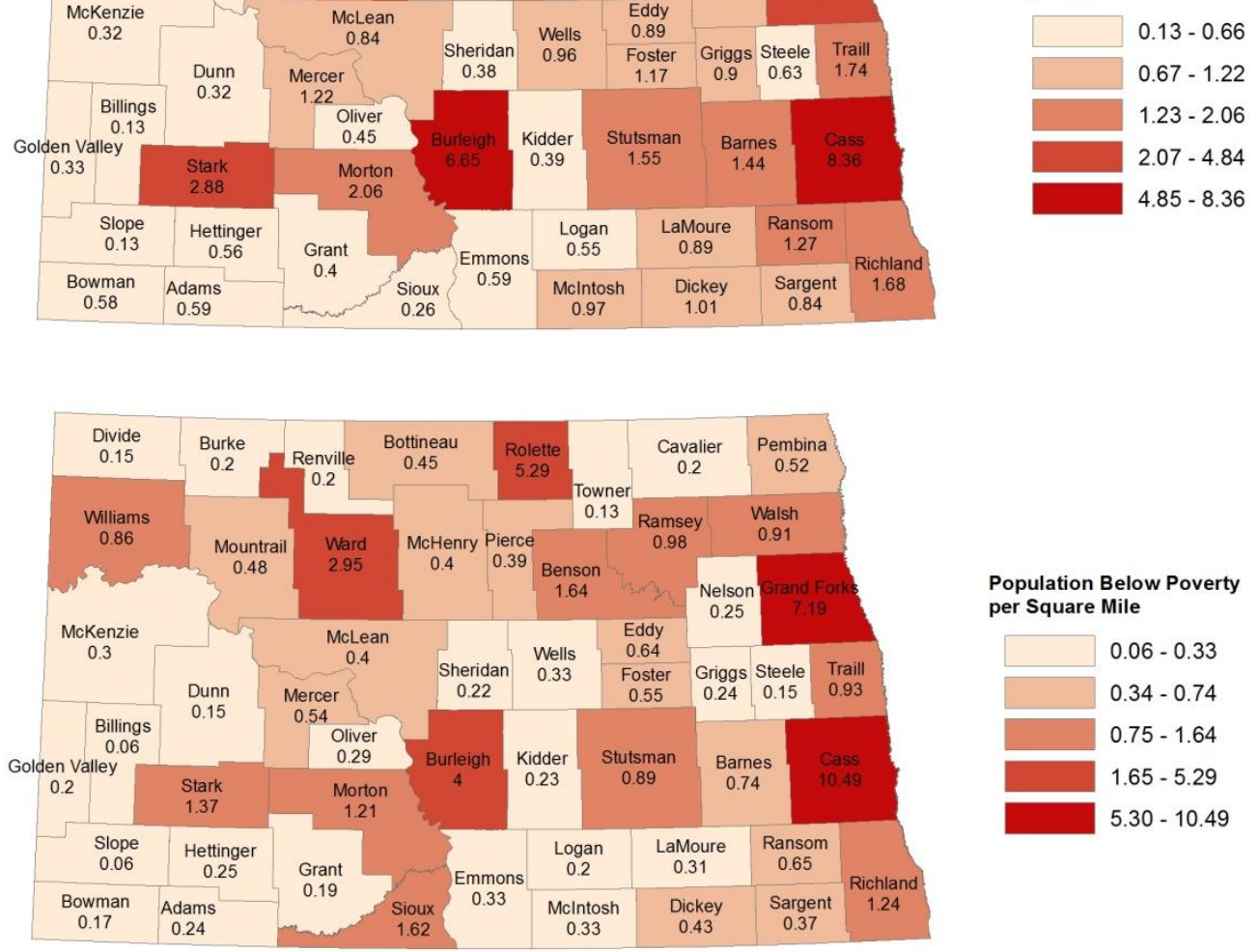

Population Below Poverty per Square Mile

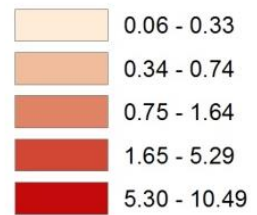




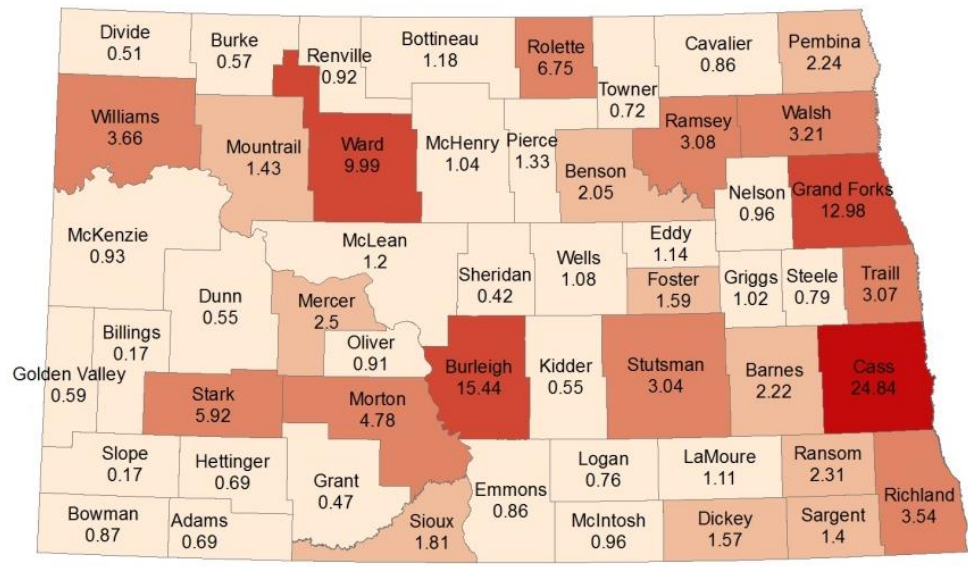

People with Disabilities per Square Mile

\begin{tabular}{|l|l|}
\hline & $0.17-1.33$ \\
$1.34-2.50$ \\
$2.51-6.75$ \\
$6.76-15.44$ \\
$15.45-24.84$
\end{tabular}

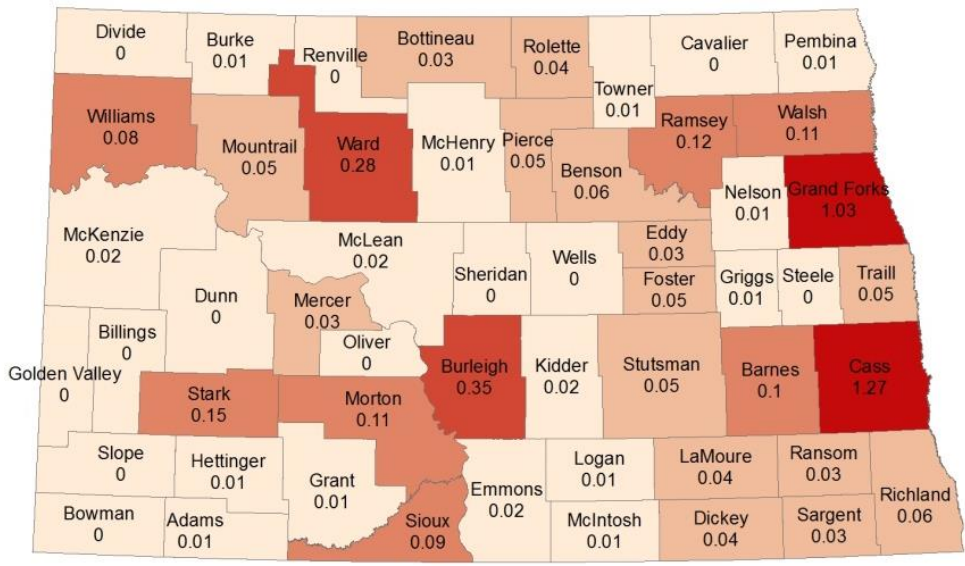

Workers with No Vehicle per Square Mile

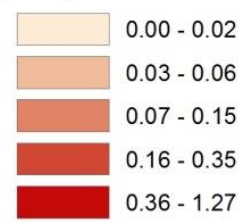




\section{APPENDIX C. PERCENTAGE OF POPULATION CONSISTING OF TRANSPORTATION-DISADVANTAGED GROUPS}
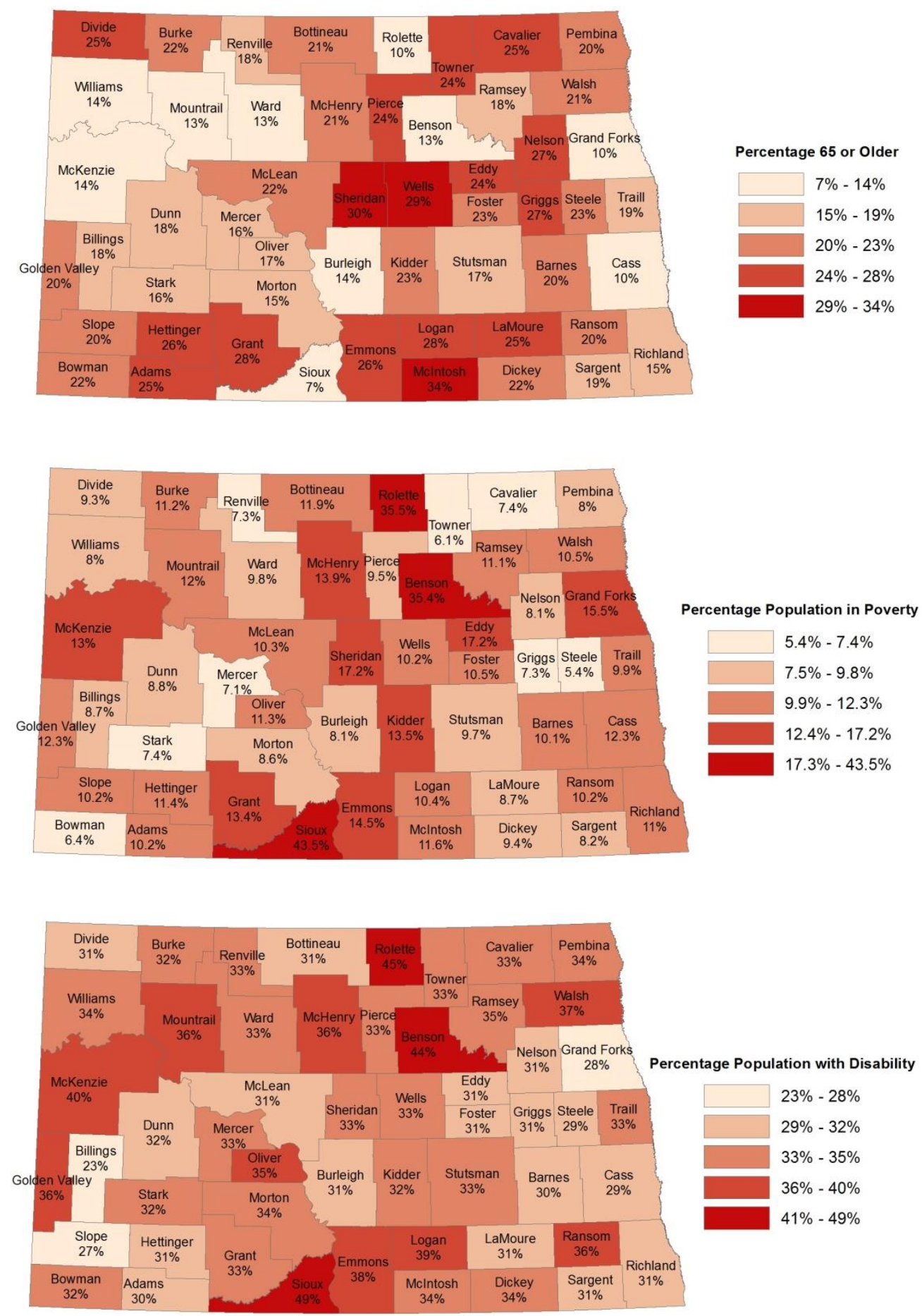


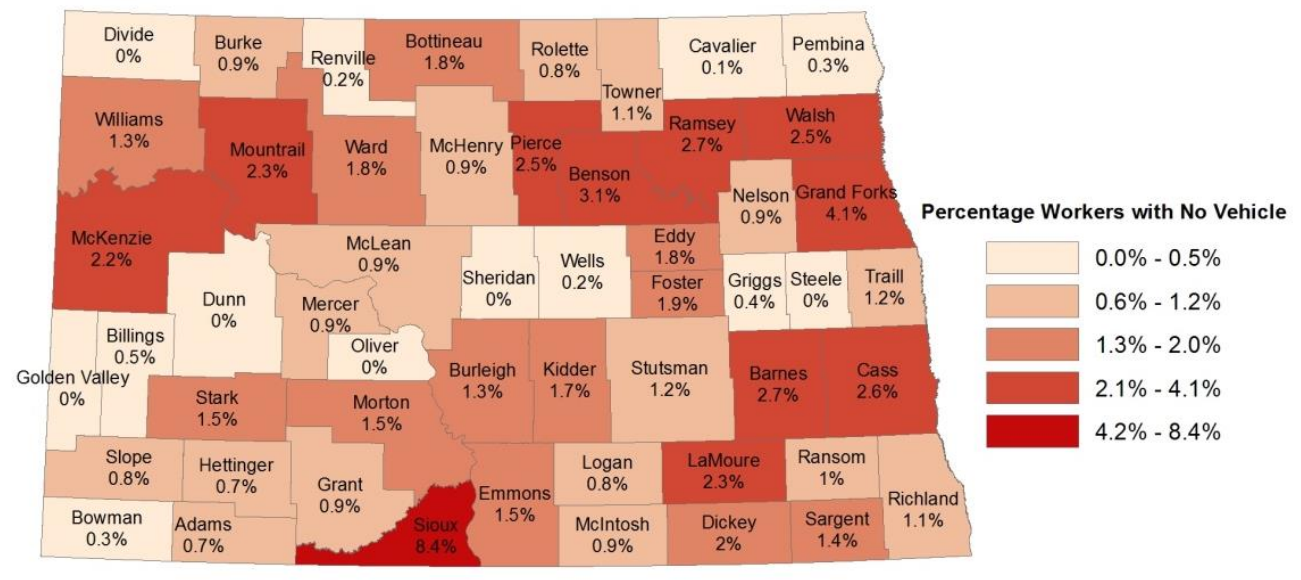




\section{APPENDIX D. RESULTS FROM SURVEY OF HUMAN SERVICE AGENCIES}

\section{Organization Name:}

North Dakota State Council on Developmental Disabilities

Knife River Group Homes, Inc.

DHS

NEHSC

Division of Vocational Rehabilitation

North Central Human Service Center

Kay's Place/North Central Human Services

North Central Human Service Center

Department of Vocational Rehabilitation

NCHSC

NWHSC

North Central Human Service Center

North Central Human Service Center

HAV-IT Services

North Central and North West Human Service Centers

ND Vocational Rehabilitation

NCHSC

REM-ND

RSI

HIT, Inc.

Northwest Human Service Center

Northwest Human Service Center

Freedom Resource Center

Protection \& Advocacy

Northwest Human Service Center Outreach

North Central Human Service Center

Fraser LTD

AARP ND

REM ND

Dakota Center for Independent Living, Inc

Dakota Center for Independent Living

Options Resource Center

Open Door Center

options resource center for independent living

Independence, Inc. Center for Independent Living

Southeast Human Service Center

Independence Inc,

Independence Inc

SUPPORT SYSTEMS INC. 
What populations does your organization serve?

\begin{tabular}{l|c|c|}
\hline Answer & Response & $\%$ \\
\hline Children and families & 23 & $58 \%$ \\
Older adults & 24 & $60 \%$ \\
The homeless & 18 & $45 \%$ \\
Low-income individuals & 24 & $60 \%$ \\
People with addictions & 22 & $55 \%$ \\
People with disabilities & 37 & $93 \%$ \\
Other, please identify & $78 \%$ \\
\hline Other, please identify & & \\
Mental Health needs & & \\
Severely mentally ill adults & & \\
people with mental health issues & & \\
Mental Health & & \\
SMI populations/IDDT & & \\
individuals age 50 and over & & \\
individuals with mental illness & &
\end{tabular}

\section{Are there any types of transportation services needed by your clients that are not currently available?}

\begin{tabular}{|l|c|c|c|}
\hline Answer & & Response & $\%$ \\
\hline Yes & & 34 & $87 \%$ \\
No & 0 & $0 \%$ \\
Not sure & 5 & $13 \%$ \\
\hline Total & & 39 & $100 \%$ \\
\hline
\end{tabular}




\section{Are any of the following types of services needed by your clients (check all that apply)?}

\begin{tabular}{|c|c|c|}
\hline Answer & Response & $\%$ \\
\hline New curb-to-curb service & 14 & $36 \%$ \\
\hline New door-to-door service & 18 & $46 \%$ \\
\hline $\begin{array}{l}\text { New door-through-door or } \\
\text { escort service }\end{array}$ & 11 & $28 \%$ \\
\hline New group pickups & 9 & $23 \%$ \\
\hline New fixed-route service & 14 & $36 \%$ \\
\hline New intercity service & 11 & $28 \%$ \\
\hline $\begin{array}{l}\text { Expansion of currently } \\
\text { available services }\end{array}$ & 34 & $87 \%$ \\
\hline Weekend service & 27 & $69 \%$ \\
\hline Longer hours of service & 35 & $90 \%$ \\
\hline Other, please explain: & 11 & $28 \%$ \\
\hline \multicolumn{3}{|l|}{ Other, please explain: } \\
\hline \multicolumn{3}{|l|}{ affordable } \\
\hline \multirow{2}{*}{\multicolumn{3}{|c|}{$\begin{array}{l}\text { Rural transportation of difficult clients, sometimes angry, irritating, who get kicked off bus services } \\
\text { The services offered in this community are limited. The Souris Basin Transportation will exile clients if } \\
\text { they fail to call and cancel a ride. They are also very difficult to arrange transportation with even } 24 \\
\text { hours in advance. }\end{array}$}} \\
\hline & & \\
\hline \multicolumn{3}{|c|}{ Services to other cities/towns that are unavailable for clients due to lack of resources. } \\
\hline \multicolumn{3}{|c|}{ lower rate cab transportation, more transportation from Watford to Williston for med services } \\
\hline \multicolumn{3}{|c|}{$\begin{array}{l}\text { needs vary by community. The ones that do have adequate services available need to expand hours to } \\
\text { evenings and week-ends... }\end{array}$} \\
\hline \multicolumn{3}{|c|}{$\begin{array}{l}\text { Hard for my disabled clients to schedule appointments in Williston on days the bus runs let alone stay } \\
\text { there until all riders are done with their business }\end{array}$} \\
\hline \multicolumn{3}{|c|}{ similar service for adults with disabilities to what college students qualify for (reduced rates) } \\
\hline \multicolumn{3}{|c|}{ Connections between public transit systems from one metro area to another } \\
\hline \multicolumn{3}{|c|}{ on demand service such as an accessible taxi service } \\
\hline \multicolumn{3}{|c|}{ ARRANGEMENT TO TRAVEL TO OTHER TOWNS } \\
\hline
\end{tabular}


Do your clients need more transportation service for any of these types of trips?

\begin{tabular}{|l|c|c|c|c|c|}
\hline Question & $\begin{array}{c}\text { No need for } \\
\text { more } \\
\text { service }\end{array}$ & $\begin{array}{c}\text { Minor need } \\
\text { for more } \\
\text { service }\end{array}$ & $\begin{array}{c}\text { Major need } \\
\text { for more } \\
\text { service }\end{array}$ & Not sure & $\begin{array}{c}\text { Total } \\
\text { Responses }\end{array}$ \\
\hline Employment & 2 & 10 & 23 & 3 & 38 \\
Education/job training & 5 & 7 & 20 & 4 & 36 \\
Medical & 4 & 13 & 20 & 1 & 38 \\
Dialysis & 7 & 5 & 6 & 16 & 34 \\
Nutrition & 7 & 8 & 7 & 12 & 34 \\
Shopping & 4 & 16 & 12 & 5 & 37 \\
Social/recreation & 3 & 14 & 20 & 3 & 40 \\
Veterans transportation & 4 & 2 & 12 & 15 & 33 \\
service & 3 & 4 & 10 & 14 & 31 \\
\hline Lift services & & & & & \\
\hline
\end{tabular}




\section{Provide any additional information or describe other types of services needed:}

We have a large number of consumers living on the reservation (Ft Totten) who would benefit from daily transportation to the HSC for treatment- especially addiction.

A number of clients living in rural areas such as Minto, Grafton, Thompson, Manvel would benefit by daily transportation to the HSC for alcohol treatment and more would benefit from weekly transportation for mental health services.

Longer service hours are greatly needed. More inner and outer city routes are desperately needed. The entire city of Minot should be serviced at a minimum.

Travel from the counties to the Human Service Center.

A larger van is needed to adequately serve all seven clients when transporting everyone at one time.

It would be nice to be able to count on a public transportation system, that regularly made stops throughout the day and into the night.

From rural areas to the city of Minot for work, social as well as medical and shopping needs. Transportation is the Number 1 barrier to people with disabilities who don't drive trying to return to work or accessing services especially in rural areas!

There are clients that participate in evening groups who do not have a license. They have limited transportation options for evening programs due to the bus route schedule. The houses we contract with in the addiction unit struggle to provide transportation to community area meetings because they of the staff shortages so they do not always get a chance to go to a meeting when it is necessary. If the options are not within $8 \mathrm{am}$ and $5 \mathrm{pm}$ it is difficult to assist clients with their transportation needs.

Transportation that can support people who uses wheelchair or other larger adaptive equipment for mobility the major need area I checked are the areas in the rural counties that I see. Valley Senior Services has a bus that is very limited to when they go, the charge is a non negotiable fee which some consumers can not afford, and when a consumer is sick and going to the Dr. in Fargo you do not want to wait for the other 5 or 6 shoppers to finish their shopping before you go home. Getting an appointment during their limited time and days VSS allow is not always easy. It is a good ride service and the people in the area are lucky to have it but it needs to be improved.

Weekend and evening transportation that is cost effective. People on Medical Assistance can't afford to take cabs.

Our information is anecdotal from conversations and based on survey data. Our impression is that there is a need for more services in most of these areas. We do not provide transportation services to our members (clients).

Transportation with less rates. Income does not stretch for clients on fixed income. Double tickets for trips not preplanned should be eliminated.

It is often difficult to find transportation for individuals living in smaller towns needed to go to bigger towns for dialysis 2 or 3 times a week. It is even more difficult to get these transportation providers to take Medicaid medical transportation vouchers.

Open Door Center provides most of the transportation for people served, however those living with families have to provide their own. Also there never seems to be sufficient vehicles for everything. The Senior Citizen group does a good job, but there is some waiting. Also there used to be bus service to the north end of town, but that has now become a cost for the residents of the low income housing in this portion of Valley City.

Lisbon's transportation is quite limited.

THE MORE RURAL YOU GET, THE LESS SERVICE AVAILABLE.

Throughout our service area, transportation is a major barrier to Independence. As our communities grow, we have more need for transportation, and bigger challenges in accessing it. The best public transportation system we have in our service area, in Minot, ends before the end of most work days. 
Overall, how well are the transportation needs of your clients being met?

\begin{tabular}{|l|c|c|c|}
\hline Answer & & Response & $\%$ \\
\hline Very well & & 0 & $0 \%$ \\
Well & 2 & $5 \%$ \\
Adequately & 15 & $38 \%$ \\
Poorly & 18 & $46 \%$ \\
Very poorly & 4 & $10 \%$ \\
\hline Total & 39 & $100 \%$ \\
\hline
\end{tabular}




\section{Explain your response to the previous question and provide any additional comments regarding the transportation needs of your clients.}

There are many people who are unable to utilize public transportation for the following reasons: 1. Fragile health needs limited some people's ability to comfortably ride on public transportation. In addition, some people are unable to ride the excessive amount of time it takes utilizing public transportation 2. Wait times for service. The time a person has to wait can be extensive. To attend an hour appointment a person may have to block several hours of time out of there schedule. 3 . Long transit rides, or unreliable schedules can and do affect people's ability to obtain and maintain employment. Example: An individual who utilizes transit attended an hour meeting. She had to arrive early for the meeting, attend the meeting and then wait close to an hour for her pick. She then had an hour ride before she was dropped off at her end destination. The person had to miss lunch because of the excessive wait time. This person is diagnosed with cerebral palsy, utilizes a wheelchair, and has limited use of her upper extremities. She was unable to independently access the backpack while waiting or riding transit.

Clients have use of the bus when it is available. However, when people have jobs, they need to be there and leave at specific times. The bus is not available for all the times. So, the needs are adequate. It helps, but there is nothing on weekends, holidays or after hours in the evening for social events. Clients then have to rely on friends and staff to take them and pick them up. It works, in that we just schedule what we can around the bus and make sure to line up rides elsewhere for when the bus is not operating or available.

When we do surveys of clients transportation to services is always a primary barrier.

Rural transportation is an issue. There are organizations who do this at times but it is usually if there is room for our clients, and if our clients are disruptive at all they are not included.

Many of my clients do not live in the city of Minot; however, they live in nearby cities. Public transportation in Minot, ND does not serve all areas of the city and they especially have no services for the surrounding cities (i.e., rugby, max, etc.) Also the public transportation system is not realistic for someone who is looking for employment. The hours of public transportation should be between

$6 a m$ to $9 \mathrm{pm}$ at a minimum. With more major retail employers in town many employees do not get off until 9pm. Many must be at work by 8am no services is available publicly for them.

Public transportation does not provide service in the evening or the weekend for those who work. Souris Basin has limited buses so there is not always seating available.

My Clients needs are met adequately when they fit within the service hours of transportation during the week. Evening and weekend public transportation is a problem for those that need it and work evening and weekends. The barriers seem greater during the winter months as it is harder to get around in the cold and snow for those who have limitations and disabilities. The transportation services at are available evenings and weekends, cost more to take and client budgets are not always able to accommodate the expense.

There is a public bus, but it is not dependable, and does not run into the evening/night. It would be nice to have a bus that started its route (a consistent route with regular stops), around 7:00 in the morning (or earlier) and ran until 9 or 10 o'clock at night. This would ensure that clients would be able to have access to public transportation without regard to the day/time.

Expansion of hours for Monday through Friday for employment transportation needs and weekend transportation is needs for the same or for shopping, rec/leisure, church. Expanding Saturday and having services on Sundays.

Costs are not allowing for transportation to necessary services. Limited services and limited number of spaces makes it difficult to access services for people with limited financial resources. 
Minot City bus has a very limited route and is geared primarily towards students in school. We have no public transportation in the City of Minot on the weekends or after $5 \mathrm{pm}$. Are you kidding me. The routes are minimal and sporadic! How are people expected to be self-sufficient when they don't have the opportunity to try. Plus the way that they manage snow removal in the winter and road care in the summer. People with disabilities can barely get around on foot or with wheel chairs. There are many locations without sidewalks or ramps on sidewalks for them to get onto the sidewalks. Not sure but may be a federal violation of the disability act. The state really needs to think about putting some money back into it or all its resources are going to be gone and the people will leave again as well.

We are fortunate to have one case aid who drives between the hours of $8 \mathrm{am}$ and $5 \mathrm{pm}$ Monday thru Friday, which covers a bulk of the transportation that is needed for our unit; however, for the clients that are served outside of that time it is a problem.

People supported by our company rely greatly on our support to transport them, however they are not always supported during the times they wish to attend community events and their socialization needs.

In Minot the services end early, are not consumer friendly, require 24 prior arrangement If clients are not on the schedule for transportation through the transit system, they may not be able to get a ride or have to wait an hour plus for a ride, which then entails missing appointments or waiting so long for a ride they skip appointments as they do not have the time or waste the time waiting for hours for an appointment. Also clients are at times referred outside the service area for medical services or other services, in which they cannot obtain transport to.

They need more on demand (personalized) transportation. Most of my clients are low income and finding the money to pay for their rides is challenging. Sometimes they go without necessary things so they can get to the appointments. I believe the local clinics should have some form of transportation for their consumers. If the person needs to see a specialist or someone in their Fargo facility, I think they should be providing help with that transportation. It only seems fair if they do not provide that service in their satellite clinics like Lisbon, Gwinner, Oakes, and so on. Employment in the small towns is limited, especially to people with disabilities. If they could get to a bigger city to work or go to school it would be possible for them to grow. Some may say just move to Fargo, well that isn't always easy either when you have special needs. I have a consumer who lives with his mom so his needs can be met, but he would love to find employment in Fargo. He could never afford living in Fargo at this time, but maybe in the future if he started a job and got on the 1-2 year waiting list for housing assisted apartments. I work in the Lisbon office for Freedom Resource Center. I cannot speak for any of the other offices Freedom RC has. My concerns on transportation are strictly in Ransom and Sargent Counties.

The topic of "transportation" comes up repeatedly when individuals with disabilities are asked about unmet needs.

Transportation is limited to specific hours when public transportation is available. The Souris River Basin Transport is a great service but it is very limited in space and time availability. Staff in our program provide much of the transportation for our clients but we are only available M-F 8-5. Basic needs are being met, however it takes long periods of time to schedule and arrange transportation (takes several hours to get from point a to b). No services are available in Frontier south of 52 nd Ave S. No availability for public transportation to church or other activities on Saturday evenings and Sundays. To wait for transportation for 30 minutes since services have a 15 minute window either way, is very difficult in the winter months or during inclement weather. If you are not a regular rider of the bus, and you are at the bus stop and wave at them they still pass you by and then it takes 3 hours to go from West Fargo to Moorhead, it took 6 hours to get to and from work. 
We don't provide direct transportation services. The population with which we work does have varying transportation needs, ranging from minor to extensive.

There is no transportation available on weekends or evenings. Clients could benefit from transportation available to recreational/leisure activities during evenings and weekends.

We need transportation to allow people with mobility impairments to go out into the community without needing to give a day's notice. Currently if someone is a wheelchair user and they decide they want to go for supper on a Saturday night they cannot go because of no transportation services available!

Transit not picking up right at the door so clients need to walk blocks on slanted driveways because drivers don't like the hassle of backing up or turning around. Some drivers do not come and let the client know they are outside or call to notify them. Therefore after 20-30 minute wait with no pick-up client must call again. Sometimes it's been an hour wait.

Transportation is adequate but could always be better, and I know there are segments of the Valley City and Lisbon area population that cannot access transportation due to cost.

PEOPLE IN RURAL AREAS NEED TRANSPORTATION FOR ALL ABOVE AREAS.

Minot has limited fixed-route, not enough hours, days, routes. With the growth of the community, area, the transit system should be growing to meet the existing and new needs. The other communities are growing as well, especially to the West. There is no other Fixed Transit in this region.

I think public transportation is adequate and some best practices approaches have been put into place (travel trainer program, half fare) but is there room to try doing some things that might be unconventional or outside the box?? 1) A lot of clients within our agency request transportation to grocery/dept stores to do their shopping instead of taking the bus. The resistance to taking the bus is that A) they can't bring several bags of groceries on the bus - no place to store them during the bus ride. Several individuals shop monthly as a means for using their budgeted funds or EBT at the beginning of the month so those funds/benefits get used for food and not used for other things because of vulnerability to others, addiction, etc. B) symptoms of anxiety, paranoia make it difficult to use the bus or go to stores during regular business hours when there are more people. I've often wondered whether there would be a way to collaborate with having a city bus available for our clients to transport to and from grocery/dept stores with the specific intention of the individuals being able to board with several bags of groceries/items or during non-traditional times when buses and stores have less people in them (Sunday mornings, later in the evenings). Clients would still need to use their bus passes. Could a bus be modified to include in bus storage (racks with bins or shelves) individuals can place their items? Could there be a utilization assessment completed to assess for feasibility, need, etc? 2) On- call transportation for individuals within our agency who are employed and need to get to and from work during non-business hours? Maybe a condition for the service is the individual is actively participating in a supportive employment program, Vocational Rehab., etc? Individuals would need to use bus passes to get a ride. 3) Transit within all the counties we serve so individuals can get to their appointments in Fargo and or utilize supports in Fargo not available in rural areas (Recovery Center, self-help groups, aftercare or evening treatment/programming). If you are a person with a disability who uses public transportation to get out of your house and participate in your community, you are significantly limited by the lack of accessible, affordable transportation. This is unacceptable.

Transportation is generally available during our hours of service. 


\section{APPENDIX E. URBAN NTD DATA, 2003-2012}

Table E.1 Urban Transit Agencies: Unlinked Passenger Trips

\begin{tabular}{|c|c|c|c|c|c|c|c|c|c|c|}
\hline & 2003 & 2004 & 2005 & 2006 & 2007 & 2008 & 2009 & 2010 & 2011 & 2012 \\
\hline \multicolumn{11}{|c|}{ Fargo: Metro Area Transit } \\
\hline Demand-Response & 34,850 & 39,705 & 40,868 & 48,989 & 55,133 & - & 57,428 & 57,850 & 58,995 & 54,543 \\
\hline Fixed-Route & 532,916 & 736,108 & 837,651 & 899,946 & 962,069 & - & $1,479,646$ & $1,570,055$ & $1,772,443$ & $1,604,693$ \\
\hline Total & 567,766 & 775,813 & 878,519 & 948,935 & $1,017,202$ & - & $1,537,074$ & $1,627,905$ & $1,831,438$ & $1,659,236$ \\
\hline \multicolumn{11}{|c|}{ Grand Forks: Cities Area Transit } \\
\hline Demand-Response & 57,140 & 59,572 & 57,804 & 43,536 & 56,063 & 60,053 & 61,630 & 65,240 & 61,078 & 55,212 \\
\hline Fixed-Route & 698,468 & 247,268 & 256,180 & 245,572 & 231,296 & 298,632 & 271,704 & 282,627 & 328,880 & 371,242 \\
\hline Total & 755,608 & 306,840 & 313,984 & 289,108 & 287,359 & 358,685 & 333,334 & 347,867 & 389,958 & 426,454 \\
\hline \multicolumn{11}{|c|}{ Bismarck: Bis-Man Transit Board } \\
\hline Demand-Response & 193,764 & 190,580 & 190,518 & 190,194 & 185,016 & 182,467 & 170,251 & 171,652 & 171,892 & 168,121 \\
\hline Fixed-Route & & 54,557 & 90,692 & 104,717 & 111,972 & 136,933 & 131,601 & 127,790 & 124,653 & 141,067 \\
\hline Total & 193,764 & 245,137 & 281,210 & 294,911 & 296,988 & 319,400 & 301,852 & 299,442 & 296,545 & 309,188 \\
\hline
\end{tabular}

Table E.2 Urban Transit Agencies: Vehicle Revenue Miles

\begin{tabular}{|c|c|c|c|c|c|c|c|c|c|c|}
\hline & 2003 & 2004 & 2005 & 2006 & 2007 & 2008 & 2009 & 2010 & 2011 & 2012 \\
\hline \multicolumn{11}{|c|}{ Fargo: Metro Area Transit } \\
\hline Demand-Response & 173,853 & 218,319 & 213,988 & 255,943 & 294,516 & - & 337,982 & 341,699 & 347,222 & 336,514 \\
\hline Fixed-Route & 559,881 & 540,123 & 527,418 & 531,056 & 553,069 & - & 625,507 & 639,047 & 782,983 & 857,329 \\
\hline Total & 733,734 & 758,442 & 741,406 & 786,999 & 847,585 & - & 963,489 & 980,746 & $1,130,205$ & $1,193,843$ \\
\hline \multicolumn{11}{|c|}{ Grand Forks: Cities Area Transit } \\
\hline Demand-Response & 271,470 & 279,420 & 283,806 & 245,536 & 245,610 & 233,758 & 260,233 & 275,768 & 256,237 & 204,665 \\
\hline Fixed-Route & 313,920 & 309,976 & 299,916 & 304,320 & 353,701 & 374,692 & 381,873 & 387,907 & 381,522 & 382,788 \\
\hline Total & 585,390 & 589,396 & 583,722 & 549,856 & 599,311 & 608,450 & 642,106 & 663,675 & 637,759 & 587,453 \\
\hline \multicolumn{11}{|c|}{ Bismarck: Bis-Man Transit Board } \\
\hline Demand-Response & 717,349 & 710,549 & 734,010 & 719,656 & 684,559 & 685,165 & 640,881 & 654,437 & 666,306 & 623,172 \\
\hline Fixed-Route & & 177,610 & 279,561 & 278,131 & 241,867 & 305,000 & 313,080 & 317,940 & 300,994 & 302,977 \\
\hline Total & 717,349 & 888,159 & $1,013,571$ & 997,787 & 926,426 & 990,165 & 953,961 & 972,377 & 967,300 & 926,149 \\
\hline
\end{tabular}


Table E.3 Urban Transit Agencies: Vehicle Revenue Hours

\begin{tabular}{|c|c|c|c|c|c|c|c|c|c|c|}
\hline & 2003 & 2004 & 2005 & 2006 & 2007 & 2008 & 2009 & 2010 & 2011 & 2012 \\
\hline \multicolumn{11}{|c|}{ Fargo: Metro Area Transit } \\
\hline Demand-Response & 15,788 & 16,699 & 16,590 & 20,126 & 23,708 & - & 24,445 & 25,494 & 26,272 & 25,442 \\
\hline Fixed-Route & 42,623 & 39,680 & 41,435 & 41,940 & 42,046 & - & 50,464 & 51,416 & 60,643 & 66,560 \\
\hline Total & 58,411 & 56,379 & 58,025 & 62,066 & 65,754 & - & 74,909 & 76,910 & 86,915 & 92,002 \\
\hline \multicolumn{11}{|c|}{ Grand Forks: Cities Area Transit } \\
\hline Demand-Response & 18,120 & 16,986 & 16,170 & 12,968 & 19,135 & 35,912 & 40,030 & 25,782 & 22,747 & 20,683 \\
\hline Fixed-Route & 20,208 & 19,696 & 20,416 & 20,824 & 23,136 & 24,959 & 25,699 & 25,705 & 24,848 & 25,292 \\
\hline Total & 38,328 & 36,682 & 36,586 & 33,792 & 42,271 & 60,871 & 65,729 & 51,487 & 47,595 & 45,975 \\
\hline \multicolumn{11}{|c|}{ Bismarck: Bis-Man Transit Board } \\
\hline Demand-Response & 53,100 & 37,636 & 54,842 & 50,861 & 48,494 & 54,000 & 46,218 & 45,732 & 46,736 & 44,507 \\
\hline Fixed-Route & & 11,237 & 20,686 & 19,952 & 19,760 & 23,000 & 19,643 & 19,787 & 19,787 & 19,787 \\
\hline Total & 53,100 & 48,873 & 75,528 & 70,813 & 68,254 & 77,000 & 65,861 & 65,519 & 66,523 & 64,294 \\
\hline
\end{tabular}

Table E.4 Urban Transit Agencies: Passenger Miles Traveled

\begin{tabular}{|c|c|c|c|c|c|c|c|c|c|c|}
\hline & 2003 & 2004 & 2005 & 2006 & 2007 & 2008 & 2009 & 2010 & 2011 & 2012 \\
\hline \multicolumn{11}{|l|}{ Fargo: Metro Area Transit } \\
\hline Demand-Response & 161,041 & 179,130 & 188,211 & 255,648 & 294,112 & - & 353,291 & 357,341 & 358,998 & 297,907 \\
\hline Fixed-Route & $1,705,708$ & $2,047,705$ & $2,394,785$ & $2,708,404$ & $3,077,554$ & - & $4,556,441$ & $5,180,088$ & $5,400,681$ & $5,050,293$ \\
\hline Total & $1,866,749$ & $2,226,835$ & $2,582,996$ & $2,964,052$ & $3,371,666$ & - & $4,909,732$ & $5,537,429$ & $5,759,679$ & $5,348,200$ \\
\hline \multicolumn{11}{|c|}{ Grand Forks: Cities Area Transit } \\
\hline Demand-Response & 163,180 & 193,576 & 195,468 & 171,932 & 183,887 & 180,723 & 260,233 & 197,204 & 172,056 & 170,704 \\
\hline Fixed-Route & $1,578,800$ & 356,412 & 355,440 & 358,204 & 353,502 & $1,184,729$ & $1,078,665$ & $1,222,029$ & $1,520,000$ & $1,524,118$ \\
\hline Total & $1,741,980$ & 549,988 & 550,908 & 530,136 & 537,389 & $1,365,452$ & $1,338,898$ & $1,419,233$ & $1,692,056$ & $1,694,822$ \\
\hline \multicolumn{11}{|c|}{ Bismarck: Bis-Man Transit Board } \\
\hline Demand-Response & 717,349 & 710,549 & 720,776 & 719,656 & 702,152 & 720,655 & 595,878 & 667,726 & 601,622 & 635,485 \\
\hline Fixed-Route & & 171,300 & 308,049 & 290,066 & 293,359 & 424,700 & 539,564 & 523,939 & 596,782 & 674,300 \\
\hline Total & 717,349 & 881,849 & $1,028,825$ & $1,009,722$ & 995,511 & $1,145,355$ & $1,135,442$ & $1,191,665$ & $1,198,404$ & $1,309,785$ \\
\hline
\end{tabular}


Table E.5 Urban Transit Agencies: Vehicles Available for Maximum Service

\begin{tabular}{|c|c|c|c|c|c|c|c|c|c|c|}
\hline & 2003 & 2004 & 2005 & 2006 & 2007 & 2008 & 2009 & 2010 & 2011 & 2012 \\
\hline \multicolumn{11}{|c|}{ Fargo: Metro Area Transit } \\
\hline Demand-Response & 8 & 8 & 8 & 9 & 10 & - & 14 & 14 & 14 & 14 \\
\hline Fixed-Route & 15 & 15 & 15 & 15 & 18 & - & 23 & 26 & 28 & 28 \\
\hline Total & 23 & 23 & 23 & 24 & 28 & - & 37 & 40 & 42 & 42 \\
\hline \multicolumn{11}{|c|}{ Grand Forks: Cities Area Transit } \\
\hline Demand-Response & 14 & 13 & 13 & 11 & 10 & 11 & 11 & 12 & 14 & 14 \\
\hline Fixed-Route & 13 & 14 & 12 & 12 & 9 & 10 & 12 & 11 & 11 & 12 \\
\hline Total & 27 & 27 & 25 & 23 & 19 & 21 & 23 & 26 & 25 & 26 \\
\hline \multicolumn{11}{|c|}{ Bismarck: Bis-Man Transit Board } \\
\hline Demand-Response & 28 & 27 & 31 & 28 & 30 & 27 & 25 & 30 & 26 & 31 \\
\hline Fixed-Route & & 8 & 9 & 10 & 10 & 9 & 8 & 12 & 10 & 10 \\
\hline Total & 28 & 35 & 40 & 38 & 40 & 36 & 33 & 42 & 36 & 41 \\
\hline
\end{tabular}

Table E.6 Urban Transit Agencies: Average Fleet Age

\begin{tabular}{|c|c|c|c|c|c|c|c|c|c|c|}
\hline & 2003 & 2004 & 2005 & 2006 & 2007 & 2008 & 2009 & 2010 & 2011 & 2012 \\
\hline \multicolumn{11}{|c|}{ Fargo: Metro Area Transit } \\
\hline Demand-Response & 0.8 & 1.8 & 2.8 & 3.3 & 3.0 & 4.0 & 2.1 & 3.1 & 3.8 & 3.7 \\
\hline Fixed-Route & 4.8 & 3.7 & 4.7 & 5.9 & 5.7 & 6.7 & 5.6 & 5.0 & 5.6 & 6.6 \\
\hline \multicolumn{11}{|c|}{ Grand Forks: Cities Area Transit } \\
\hline Demand-Response & 2.7 & 4.0 & 5.0 & & & & & 1.0 & 1.9 & 2.2 \\
\hline Fixed-Route & 9.4 & 7.9 & 7.3 & 4.7 & 5.3 & 6.3 & 6.7 & 4.7 & 3.8 & 4.8 \\
\hline \multicolumn{11}{|c|}{ Bismarck: Bis-Man Transit Board } \\
\hline Demand-Response & 6.1 & 7.2 & 4.9 & 5.3 & 5.8 & 6.4 & 5.6 & 5.9 & 5.9 & 5.3 \\
\hline Fixed-Route & & 3.0 & 4.8 & 5.8 & 5.8 & 4.6 & 5.5 & 5.9 & 5.4 & 6.4 \\
\hline
\end{tabular}


Table E.7 Urban Transit Agencies: Total Operating Expenses

\begin{tabular}{|c|c|c|c|c|c|c|c|c|c|c|}
\hline & 2003 & 2004 & 2005 & 2006 & 2007 & 2008 & 2009 & 2010 & 2011 & 2012 \\
\hline \multicolumn{11}{|c|}{ Fargo: Metro Area Transit } \\
\hline Demand-Response & 0.47 & 0.54 & 0.55 & 0.69 & 0.95 & - & 1.18 & 1.23 & 1.23 & 1.25 \\
\hline Fixed-Route & 1.64 & 1.92 & 2.01 & 2.37 & 3.01 & - & 3.86 & 4.19 & 4.42 & 4.98 \\
\hline Total & 2.11 & 2.46 & 2.56 & 3.06 & 3.96 & - & 5.04 & 5.43 & 5.65 & 6.23 \\
\hline \multicolumn{11}{|c|}{ Grand Forks: Cities Area Transit } \\
\hline Demand-Response & 0.44 & 0.14 & 0.47 & 0.25 & 0.40 & 0.50 & 0.53 & 0.59 & 0.83 & 0.97 \\
\hline Fixed-Route & 1.22 & 1.29 & 1.29 & 1.41 & 1.49 & 1.59 & 1.63 & 1.78 & 1.91 & 1.86 \\
\hline Total & 1.66 & 1.42 & 1.76 & 1.66 & 1.89 & 2.09 & 2.16 & 2.37 & 2.74 & 2.82 \\
\hline \multicolumn{11}{|c|}{ Bismarck: Bis-Man Transit Board } \\
\hline Demand-Response & 1.69 & 1.45 & 1.19 & 1.38 & 1.50 & 1.71 & 1.70 & 1.67 & 1.83 & 1.88 \\
\hline Fixed-Route & & 0.44 & 0.76 & 0.71 & 0.87 & 0.96 & 0.99 & 1.04 & 1.32 & 1.39 \\
\hline Total & 1.69 & 1.90 & 1.95 & 2.10 & 2.37 & 2.66 & 2.69 & 2.71 & 3.15 & 3.27 \\
\hline
\end{tabular}

Table E.8 Urban Transit Agencies: Unlinked Passenger Trips per Vehicle Revenue Mile

\begin{tabular}{|c|c|c|c|c|c|c|c|c|c|c|}
\hline & 2003 & 2004 & 2005 & 2006 & 2007 & 2008 & 2009 & 2010 & 2011 & 2012 \\
\hline \multicolumn{11}{|c|}{ Fargo: Metro Area Transit } \\
\hline Demand-Response & 0.20 & 0.18 & 0.19 & 0.19 & 0.19 & - & 0.17 & 0.17 & 0.17 & 0.16 \\
\hline Fixed-Route & 0.95 & 1.36 & 1.59 & 1.69 & 1.74 & - & 2.37 & 2.46 & 2.26 & 1.87 \\
\hline Total & 0.77 & 1.02 & 1.18 & 1.21 & 1.20 & - & 1.60 & 1.66 & 1.62 & 1.39 \\
\hline \multicolumn{11}{|c|}{ Grand Forks: Cities Area Transit } \\
\hline Demand-Response & 0.21 & 0.21 & 0.20 & 0.18 & 0.23 & 0.26 & 0.24 & 0.24 & 0.24 & 0.27 \\
\hline Fixed-Route & 2.22 & 0.80 & 0.85 & 0.81 & 0.65 & 0.80 & 0.71 & 0.73 & 0.86 & 0.97 \\
\hline Total & 1.29 & 0.52 & 0.54 & 0.53 & 0.48 & 0.59 & 0.52 & 0.52 & 0.61 & 0.73 \\
\hline \multicolumn{11}{|c|}{ Bismarck: Bis-Man Transit Board } \\
\hline Demand-Response & 0.27 & 0.27 & 0.26 & 0.26 & 0.27 & 0.27 & 0.27 & 0.26 & 0.26 & 0.27 \\
\hline Fixed-Route & & 0.31 & 0.32 & 0.38 & 0.46 & 0.45 & 0.42 & 0.40 & 0.41 & 0.47 \\
\hline Total & 0.27 & 0.28 & 0.28 & 0.30 & 0.32 & 0.32 & 0.32 & 0.31 & 0.31 & 0.33 \\
\hline
\end{tabular}


Table E.9 Urban Transit Agencies: Unlinked Passenger Trips per Vehicle Revenue Hour

\begin{tabular}{|c|c|c|c|c|c|c|c|c|c|c|}
\hline & 2003 & 2004 & 2005 & 2006 & 2007 & 2008 & 2009 & 2010 & 2011 & 2012 \\
\hline \multicolumn{11}{|c|}{ Fargo: Metro Area Transit } \\
\hline Demand-Response & 2.21 & 2.38 & 2.46 & 2.43 & 2.33 & - & 2.35 & 2.27 & 2.25 & 2.14 \\
\hline Fixed-Route & 12.50 & 18.55 & 20.22 & 21.46 & 22.88 & - & 29.32 & 30.54 & 29.23 & 24.11 \\
\hline Total & 9.72 & 13.76 & 15.14 & 15.29 & 15.47 & - & 20.52 & 21.17 & 21.07 & 18.03 \\
\hline \multicolumn{11}{|c|}{ Grand Forks: Cities Area Transit } \\
\hline Demand-Response & 3.15 & 3.51 & 3.57 & 3.36 & 2.93 & 1.67 & 1.54 & 2.53 & 2.69 & 2.67 \\
\hline Fixed-Route & 34.56 & 12.55 & 12.55 & 11.79 & 10.00 & 11.96 & 10.57 & 11.00 & 13.24 & 14.68 \\
\hline Total & 19.71 & 8.36 & 8.58 & 8.56 & 6.80 & 5.89 & 5.07 & 6.76 & 8.19 & 9.28 \\
\hline \multicolumn{11}{|c|}{ Bismarck: Bis-Man Transit Board } \\
\hline Demand-Response & 3.65 & 5.06 & 3.47 & 3.74 & 3.82 & 3.38 & 3.68 & 3.75 & 3.68 & 3.78 \\
\hline Fixed-Route & & 4.86 & 4.38 & 5.25 & 5.67 & 5.95 & 6.70 & 6.46 & 6.30 & 7.13 \\
\hline Total & 3.65 & 5.02 & 3.72 & 4.16 & 4.35 & 4.15 & 4.58 & 4.57 & 4.46 & 4.81 \\
\hline
\end{tabular}

Table E.10 Urban Transit Agencies: Unlinked Passenger Trips per Vehicle

\begin{tabular}{|c|c|c|c|c|c|c|c|c|c|c|}
\hline & 2003 & 2004 & 2005 & 2006 & 2007 & 2008 & 2009 & 2010 & 2011 & 2012 \\
\hline \multicolumn{11}{|c|}{ Fargo: Metro Area Transit } \\
\hline Demand-Response & 4,356 & 4,963 & 5,109 & 5,443 & 5,513 & - & 4,102 & 4,132 & 3,687 & 3,896 \\
\hline Fixed-Route & 35,528 & 43,300 & 49,274 & 49,997 & 45,813 & - & 64,332 & 60,387 & 63,302 & 57,310 \\
\hline Total & 24,685 & 31,033 & 35,141 & 35,146 & 32,813 & - & 41,543 & 40,698 & 41,624 & 39,506 \\
\hline \multicolumn{11}{|c|}{ Grand Forks: Cities Area Transit } \\
\hline Demand-Response & 4,081 & 4,582 & 4,446 & 3,958 & 5,097 & 5,459 & 6,163 & 5,018 & 4,698 & 2,629 \\
\hline Fixed-Route & 53,728 & 17,662 & 21,348 & 20,464 & 19,275 & 24,886 & 22,642 & 23,552 & 27,407 & 30,937 \\
\hline Total & 27,985 & 11,364 & 12,559 & 12,570 & 12,494 & 15,595 & 15,152 & 13,915 & 15,598 & 12,923 \\
\hline \multicolumn{11}{|c|}{ Bismarck: Bis-Man Transit Board } \\
\hline Demand-Response & 7,176 & 6,806 & 8,283 & 9,510 & 6,608 & 6,758 & 5,159 & 5,537 & 5,372 & 5,423 \\
\hline Fixed-Route & & 6,820 & 11,337 & 10,472 & 11,197 & 15,215 & 16,450 & 9,830 & 12,465 & 14,107 \\
\hline Total & 7,176 & 6,809 & 9,071 & 9,830 & 7,815 & 8,872 & 7,362 & 6,806 & 7,061 & 7,541 \\
\hline
\end{tabular}


Table E.11 Urban Transit Agencies: Vehicle Revenue Miles per Vehicle

\begin{tabular}{|c|c|c|c|c|c|c|c|c|c|c|}
\hline & 2003 & 2004 & 2005 & 2006 & 2007 & 2008 & 2009 & 2010 & 2011 & 2012 \\
\hline \multicolumn{11}{|c|}{ Fargo: Metro Area Transit } \\
\hline Demand-Response & 21,732 & 27,290 & 26,749 & 28,438 & 29,452 & - & 24,142 & 24,407 & 21,701 & 24,037 \\
\hline Fixed-Route & 37,325 & 31,772 & 31,025 & 29,503 & 26,337 & - & 27,196 & 24,579 & 27,964 & 30,619 \\
\hline Total & 31,901 & 30,338 & 29,656 & 29,148 & 27,341 & - & 26,040 & 24,519 & 25,686 & 28,425 \\
\hline \multicolumn{11}{|c|}{ Grand Forks: Cities Area Transit } \\
\hline Demand-Response & 19,391 & 21,494 & 21,831 & 22,321 & 22,328 & 21,251 & 26,023 & 21,213 & 19,711 & 9,746 \\
\hline Fixed-Route & 24,148 & 22,141 & 24,993 & 25,360 & 29,475 & 31,224 & 31,823 & 32,326 & 31,794 & 31,899 \\
\hline Total & 21,681 & 21,829 & 23,349 & 23,907 & 26,057 & 26,454 & 29,187 & 26,547 & 25,510 & 17,802 \\
\hline \multicolumn{11}{|c|}{ Bismarck: Bis-Man Transit Board } \\
\hline Demand-Response & 26,568 & 25,377 & 31,913 & 35,983 & 24,449 & 25,376 & 19,421 & 21,111 & 20,822 & 20,102 \\
\hline Fixed-Route & & 22,201 & 34,945 & 27,813 & 24,187 & 33,889 & 39,135 & 24,457 & 30,099 & 30,298 \\
\hline Total & 26,568 & 24,671 & 32,696 & 33,260 & 24,380 & 27,505 & 23,267 & 22,099 & 23,031 & 22,589 \\
\hline
\end{tabular}

Table E.12 Urban Transit Agencies: Vehicle Revenue Hours per Vehicle

\begin{tabular}{|c|c|c|c|c|c|c|c|c|c|c|}
\hline & 2003 & 2004 & 2005 & 2006 & 2007 & 2008 & 2009 & 2010 & 2011 & 2012 \\
\hline \multicolumn{11}{|c|}{ Fargo: Metro Area Transit } \\
\hline Demand-Response & 1,974 & 2,087 & 2,074 & 2,236 & 2,371 & - & 1,746 & 1,821 & 1,642 & 1,817 \\
\hline Fixed-Route & 2,842 & 2,334 & 2,437 & 2,330 & 2,002 & - & 2,194 & 1,978 & 2,166 & 2,377 \\
\hline Total & 2,540 & 2,255 & 2,321 & 2,299 & 2,121 & - & 2,025 & 1,923 & 1,975 & 2,191 \\
\hline \multicolumn{11}{|c|}{ Grand Forks: Cities Area Transit } \\
\hline Demand-Response & 1,294 & 1,307 & 1,244 & 1,179 & 1,740 & 3,265 & 4,003 & 1,983 & 1,750 & 985 \\
\hline Fixed-Route & 1,554 & 1,407 & 1,701 & 1,735 & 1,928 & 2,080 & 2,142 & 2,142 & 2,071 & 2,108 \\
\hline Total & 1,420 & 1,359 & 1,463 & 1,469 & 1,838 & 2,647 & 2,988 & 2,059 & 1,904 & 1,393 \\
\hline \multicolumn{11}{|c|}{ Bismarck: Bis-Man Transit Board } \\
\hline Demand-Response & 1,967 & 1,344 & 2,384 & 2,543 & 1,732 & 2,000 & 1,401 & 1,475 & 1,461 & 1,436 \\
\hline Fixed-Route & & 1,405 & 2,586 & 1,995 & 1,976 & 2,556 & 2,455 & 1,522 & 1,979 & 1,979 \\
\hline Total & 1,967 & 1,358 & 2,436 & 2,360 & 1,796 & 2,139 & 1,606 & 1,489 & 1,584 & 1,568 \\
\hline
\end{tabular}


Table E.13 Urban Transit Agency: Operating Cost per Trip

\begin{tabular}{|c|c|c|c|c|c|c|c|c|c|c|}
\hline & 2003 & 2004 & 2005 & 2006 & 2007 & 2008 & 2009 & 2010 & 2011 & 2012 \\
\hline \multicolumn{11}{|c|}{ Fargo: Metro Area Transit } \\
\hline Demand-Response & 13.48 & 13.51 & 13.46 & 14.17 & 17.21 & - & 20.51 & 21.31 & 20.79 & 22.86 \\
\hline Fixed-Route & 3.09 & 2.61 & 2.40 & 2.63 & 3.13 & - & 2.61 & 2.67 & 2.50 & 3.11 \\
\hline Total & 3.72 & 3.17 & 2.92 & 3.23 & 3.90 & - & 3.28 & 3.33 & 3.08 & 3.76 \\
\hline \multicolumn{11}{|c|}{ Grand Forks: Cities Area Transit } \\
\hline Demand-Response & 7.76 & 2.32 & 8.11 & 5.71 & 7.17 & 8.38 & 8.65 & 9.03 & 13.64 & 17.54 \\
\hline Fixed-Route & 1.75 & 5.20 & 5.02 & 5.74 & 6.45 & 5.32 & 6.00 & 6.29 & 5.81 & 5.00 \\
\hline Total & 2.20 & 4.64 & 5.59 & 5.73 & 6.59 & 5.83 & 6.49 & 6.80 & 7.04 & 6.62 \\
\hline \multicolumn{11}{|c|}{ Bismarck: Bis-Man Transit Board } \\
\hline Demand-Response & 8.70 & 7.62 & 6.24 & 7.27 & 8.11 & 9.35 & 9.97 & 9.74 & 10.64 & 11.18 \\
\hline Fixed-Route & & 8.14 & 8.34 & 6.80 & 7.75 & 7.01 & 7.51 & 8.12 & 10.59 & 9.85 \\
\hline Total & 8.70 & 7.74 & 6.92 & 7.10 & 7.97 & 8.34 & 8.90 & 9.05 & 10.62 & 10.57 \\
\hline
\end{tabular}

Table E.14 Urban Transit Agency: Operating Cost per Vehicle Revenue Mile

\begin{tabular}{|c|c|c|c|c|c|c|c|c|c|c|}
\hline & 2003 & 2004 & 2005 & 2006 & 2007 & 2008 & 2009 & 2010 & 2011 & 2012 \\
\hline \multicolumn{11}{|c|}{ Fargo: Metro Area Transit } \\
\hline Demand-Response & 2.70 & 2.46 & 2.57 & 2.71 & 3.22 & - & 3.49 & 3.61 & 3.53 & 3.71 \\
\hline Fixed-Route & 2.94 & 3.55 & 3.81 & 4.46 & 5.45 & - & 6.17 & 6.56 & 5.65 & 5.81 \\
\hline Total & 2.88 & 3.24 & 3.45 & 3.89 & 4.68 & - & 5.23 & 5.53 & 5.00 & 5.22 \\
\hline \multicolumn{11}{|c|}{ Grand Forks: Cities Area Transit } \\
\hline Demand-Response & 1.63 & 0.49 & 1.65 & 1.01 & 1.64 & 2.15 & 2.05 & 2.14 & 3.25 & 4.73 \\
\hline Fixed-Route & 3.89 & 4.15 & 4.29 & 4.63 & 4.22 & 4.24 & 4.27 & 4.58 & 5.01 & 4.85 \\
\hline Total & 2.84 & 2.42 & 3.01 & 3.01 & 3.16 & 3.44 & 3.37 & 3.57 & 4.30 & 4.81 \\
\hline \multicolumn{11}{|c|}{ Bismarck: Bis-Man Transit Board } \\
\hline Demand-Response & 2.35 & 2.04 & 1.62 & 1.92 & 2.19 & 2.49 & 2.65 & 2.55 & 2.75 & 3.02 \\
\hline Fixed-Route & & 2.50 & 2.71 & 2.56 & 3.59 & 3.15 & 3.16 & 3.26 & 4.38 & 4.59 \\
\hline Total & 2.35 & 2.13 & 1.92 & 2.10 & 2.56 & 2.69 & 2.82 & 2.79 & 3.26 & 3.53 \\
\hline
\end{tabular}


Table E.15 Urban Transit Agencies: Farebox Recovery Ratio

\begin{tabular}{|c|c|c|c|c|c|c|c|c|c|c|}
\hline & 2003 & 2004 & 2005 & 2006 & 2007 & 2008 & 2009 & 2010 & 2011 & 2012 \\
\hline \multicolumn{11}{|c|}{ Fargo: Metro Area Transit } \\
\hline Demand-Response & $31 \%$ & $33 \%$ & $33 \%$ & $31 \%$ & $27 \%$ & - & $35 \%$ & $25 \%$ & $24 \%$ & $25 \%$ \\
\hline Fixed-Route & $17 \%$ & $15 \%$ & $15 \%$ & $17 \%$ & $12 \%$ & - & $17 \%$ & $15 \%$ & $13 \%$ & $13 \%$ \\
\hline Total & $20 \%$ & $19 \%$ & $19 \%$ & $20 \%$ & $16 \%$ & - & $21 \%$ & $17 \%$ & $16 \%$ & $15 \%$ \\
\hline \multicolumn{11}{|c|}{ Grand Forks: Cities Area Transit } \\
\hline Demand-Response & $25 \%$ & $94 \%$ & $25 \%$ & $0 \%$ & $34 \%$ & $29 \%$ & $31 \%$ & $30 \%$ & $24 \%$ & $17 \%$ \\
\hline Fixed-Route & $12 \%$ & $9 \%$ & $10 \%$ & $10 \%$ & $9 \%$ & $10 \%$ & $10 \%$ & $9 \%$ & $10 \%$ & $12 \%$ \\
\hline Total & $15 \%$ & $17 \%$ & $14 \%$ & $9 \%$ & $14 \%$ & $15 \%$ & $15 \%$ & $15 \%$ & $14 \%$ & $13 \%$ \\
\hline \multicolumn{11}{|c|}{ Bismarck: Bis-Man Transit Board } \\
\hline Demand-Response & $19 \%$ & $25 \%$ & $31 \%$ & $29 \%$ & $22 \%$ & $21 \%$ & $24 \%$ & $24 \%$ & $22 \%$ & $20 \%$ \\
\hline Fixed-Route & & $4 \%$ & $5 \%$ & $7 \%$ & $6 \%$ & $9 \%$ & $7 \%$ & $6 \%$ & $5 \%$ & $6 \%$ \\
\hline Total & $19 \%$ & $20 \%$ & $21 \%$ & $21 \%$ & $16 \%$ & $17 \%$ & $18 \%$ & $18 \%$ & $15 \%$ & $14 \%$ \\
\hline
\end{tabular}

Table E.16 Urban Transit Agencies: Operating Funds by Source

\begin{tabular}{|c|c|c|c|c|c|c|c|c|c|c|}
\hline & 2003 & 2004 & 2005 & 2006 & 2007 & 2008 & 2009 & 2010 & 2011 & 2012 \\
\hline \multicolumn{11}{|c|}{ Fargo: Metro Area Transit } \\
\hline Federal & 1,052 & 1,177 & 1,195 & 1,485 & 1,577 & - & 1,976 & 1,957 & 2,068 & 2,007 \\
\hline State & 140 & 130 & 65 & 252 & 268 & - & 515 & 316 & 349 & 574 \\
\hline Local & 448 & 680 & 679 & 562 & 789 & - & 610 & 1,318 & 1,388 & 1,599 \\
\hline Fare Revenue & 422 & 462 & 488 & 610 & 615 & - & 1,069 & 934 & 884 & 965 \\
\hline Other & 53 & 7 & 135 & 154 & 712 & - & 866 & 901 & 960 & 1,086 \\
\hline Total & 2,114 & 2,456 & 2,562 & 3,064 & 3,963 & - & 5,036 & 5,427 & 5,649 & 6,231 \\
\hline \multicolumn{11}{|c|}{ Grand Forks: Cities Area Transit } \\
\hline Federal & 688 & 733 & 908 & 753 & 506 & 765 & 861 & 950 & 998 & 1,134 \\
\hline State & 104 & 49 & 49 & 181 & 185 & 207 & 201 & 226 & 209 & 191 \\
\hline Local & 429 & 533 & 511 & 530 & 671 & 610 & 566 & 625 & 828 & 794 \\
\hline Fare Revenue & 249 & 242 & 249 & 144 & 272 & 310 & 333 & 343 & 391 & 375 \\
\hline Other & 192 & 198 & 38 & 48 & 261 & 200 & 202 & 222 & 319 & 329 \\
\hline Total & 1,663 & 1,755 & 1,756 & 1,657 & 1,895 & 2,091 & 2,163 & 2,367 & 2,744 & 2,825 \\
\hline \multicolumn{11}{|c|}{ Bismarck: Bis-Man Transit Board } \\
\hline Federal & 579 & 728 & 907 & 952 & 1,105 & 1,217 & 1,193 & 1,230 & 1,317 & 1,440 \\
\hline State & 146 & 67 & 134 & 252 & 254 & 283 & 309 & 306 & 247 & 513 \\
\hline Local & 418 & 423 & 329 & 356 & 550 & 587 & 650 & 673 & 696 & 720 \\
\hline Fare Revenue & 315 & 385 & 414 & 450 & 387 & 448 & 473 & 331 & 464 & 461 \\
\hline Other & 228 & 36 & 162 & 85 & 72 & 129 & 62 & 170 & 425 & 135 \\
\hline Total & 1,686 & 1,640 & 1,946 & 2,095 & 2,368 & 2,665 & 2,686 & 2,709 & 3,149 & 3,269 \\
\hline
\end{tabular}


Table E.17 Urban Transit Agencies: Capital Funds by Source

\begin{tabular}{|c|c|c|c|c|c|c|c|c|c|c|}
\hline & 2003 & 2004 & 2005 & 2006 & 2007 & 2008 & 2009 & 2010 & 2011 & 2012 \\
\hline \multicolumn{11}{|c|}{ Fargo: Metro Area Transit } \\
\hline Federal & 1,184 & 1,202 & 825 & 2,254 & 1,106 & - & 2,409 & 2,145 & 1,447 & 105 \\
\hline State & 0 & 0 & 0 & 0 & 0 & - & 33 & 8 & 0 & 0 \\
\hline Local & 296 & 301 & 206 & 564 & 276 & - & 222 & -84 & 268 & 25 \\
\hline Other & 0 & 0 & 0 & 0 & 0 & - & 253 & 86 & 54 & 0 \\
\hline Total & 1,480 & 1,503 & 1,031 & 2,818 & 1,382 & - & 2,917 & 2,156 & 1,769 & 131 \\
\hline \multicolumn{11}{|c|}{ Grand Forks: Cities Area Transit } \\
\hline Federal & 309 & 628 & 284 & 204 & 124 & 23 & 362 & 2,516 & 462 & 339 \\
\hline State & 0 & 0 & 0 & 0 & 0 & 0 & 0 & 0 & 0 & 5 \\
\hline Local & 0 & 0 & 78 & 56 & 20 & 1 & 89 & 254 & 0 & 75 \\
\hline Other & 66 & 0 & 0 & 0 & 0 & 0 & 0 & 42 & 0 & 6 \\
\hline Total & 375 & 628 & 362 & 260 & 144 & 24 & 451 & 2,812 & 462 & 423 \\
\hline \multicolumn{11}{|c|}{ Bismarck: Bis-Man Transit Board } \\
\hline Federal & 403 & 966 & 364 & 548 & 325 & 47 & 580 & 1,479 & 1,808 & 589 \\
\hline State & 0 & 0 & 0 & 0 & 0 & 0 & 0 & 0 & 0 & 0 \\
\hline Local & 173 & 159 & 122 & 137 & 0 & 0 & 0 & 0 & 0 & 0 \\
\hline Other & 0 & 93 & 0 & 0 & 81 & 0 & 0 & 144 & 0 & 0 \\
\hline Total & 576 & 1,219 & 486 & 685 & 407 & 47 & 580 & 1,624 & 1,808 & 589 \\
\hline
\end{tabular}




\section{APPENDIX F. TRANSIT AGENCY INFORMATION}

This appendix provides detailed responses from transit agencies regarding their current facilities, needed facility upgrades, additional services needed, challenges to providing additional services, staffing needs, comments about how well they are meeting the needs of their service area residents, and other comments. Also provided is each agency's most recent service data.

\section{Benson County Transportation}

Counties: Benson, Wells, Pierce, Ramsey

Service provided: Door-to-door

\section{Service Data}

Total trips:

Vehicles:

Vehicle miles:

Vehicle hours:

Operating expense:

\section{Facilities:}

Maintenance:

Storage:

Administrative:

Needed upgrades:

Staffing needs:

$$
3,410
$$

4

62,230

2,222

$\$ 82,880$

Use local Farmers Union Oil Co.

2 parking spots in Benson County Highway Department garage in Maddock. Do Not Own.

Rent office space in Maddock Business and Technology Center, Maddock

Would like to have our own parking garage.

More staff needed if in future do more transportation on the reservation. 


\section{Bis-Man Transit Board}

\section{Counties: $\quad$ Burleigh and Morton \\ Service provided: $\quad$ Fixed-route; Door-to-door \\ 2013 Service Data}

\section{Fixed-Route}

Total trips:

135,466

Vehicles:

10

Vehicle miles:

300,704

Vehicle hours:

19,944

Operating expense:

$\$ 1,441,080$

Demand-Response

Total trips:

160,582

Vehicles:

Vehicle miles:

628,858

Vehicle hours:

44,488

Operating expense: $\quad \$ 1,985,166$

\section{Facilities:}

Maintenance: $\quad$ We have one large facility with a Maintenance shop

Storage: $\quad$ we have 3 garages under one roof

Administrative: $\quad$ Our administrative offices are in our same facility with the garages and maintenance shop.

Needed upgrades:

Services needed:

New door-through-door or escort service; Expansion of currently available services; Weekend service; Longer hours of service

Challenges: Funds

Meeting needs of Services are being done well but we need to work on our (on time residents: performance)

Other comments: $\quad$ Funds for both operating and capital. 


\section{Cando Transportation}

Counties:

Towner

\section{Service Data}

Total trips:

5,651

Vehicles:

2

Vehicle miles:

45,377

Vehicle hours:

3,260

Operating expense:

$\$ 59,198$

\section{Cavalier County Transit}

Counties:

Service provided:

\section{Service Data}

Total trips:

Vehicles:

Vehicle miles:

Vehicle hours:

Operating expense:

Facilities:

Maintenance:

Storage:

Administrative:

Needed upgrades:

Services needed:

Challenges:

Staffing needs:

Meeting needs of residents:
Cavalier

Door-to-door 5,088

\section{2}

15,157

2,260

$\$ 53,971$

We do not have a maintenance facility.

We own a large garage that currently houses 2 mini vans and our small bus. It is tight quarters. We are currently planning a remodel of the administrative building that will have a space for one of the mini-vans.

We rent the office space in a building that is owned by the Langdon Area Senior Citizens Club. There is a private office for the director and an open office space with 3 desks, filing cabinets and a large printer.

Upgrades to vehicle storage facilities.

Trips to Fargo

We don't have the staff or time to provide trips to Fargo. We try to coordinate trips with other agencies that do provide that service but have been unsuccessful.

Currently we have 1 full-time driver, 1 part-time driver and 3 substitutes.

We are able to pick people up before and after business hours for medical appointments when necessary. 


\section{Dickey County Transportation}

\begin{tabular}{lr} 
Counties: & \multicolumn{2}{l}{ Dickey } \\
Service provided: & Door-to-door \\
$\mathbf{2 0 1 3}$ Service Data & \\
Total trips: & 5,167 \\
Vehicles: & 2 \\
Vehicle miles: & 10,507 \\
Vehicle hours: & 1,809 \\
Operating expense: & $\$ 53,900$
\end{tabular}

\section{Facilities:}

Maintenance: $\quad$ Use local mechanic shops or body shops

Storage: $\quad$ Rent garage for one vehicle, rent part of a large shed for another vehicle

Administrative: $\quad$ Agency also provides seniors services. Admin space is in a Senior Center where we rent space.

Staffing needs: If demand increases than we would need to add driver hours and/or drivers as current drivers are part time.

Meeting needs of I am sure there are gaps - but what are the additional continuing needs? We residents: do not seem to get requests for ongoing services. We do not fill the occasional one person wants to go somewhere once requests that we sometimes get.

Other comments: This rural county has a lot of services and businesses in the county - more compared to surrounding counties which seems to lessen the need/desire to go out of county to access services. 


\section{Dickinson Public Transit (Elder Care)}

Counties:

Service provided:

2013 Service Data

Total trips:

Vehicles:

Vehicle miles:

Vehicle hours:

Operating expense:
Stark, Morton, Burleigh, occasionally Billings, and Dunn

Curb-to-curb; Door-to-door

Facilities:

Maintenance: $\quad$ We do not have a maintenance facility.

Storage: $\quad$ Our garage holds 11 vehicles with overflow outside. Garage size is: 80 feet by 90 feet. We do not own our facility....the City of Dickinson owns it.

Administrative: $\quad$ Administrative offices are adequate. Size is: 80 feet by 32 feet, minus mechanical room space of approximately 13 feet by 12 feet. We do not own our facility....the City of Dickinson owns it.

Needed upgrades: We are unable to park all of our vehicles inside the garage for safety and protection from inclement weather. We are in need of a training/meeting room for our administrative facilities.

Services needed: $\quad$ New door-through-door or escort service; New fixed-route service; Expansion of currently available services; More days/trips to Bismarck. Need more transit services for out of town trips.

Challenges:

Staffing needs:

\author{
Meeting needs of \\ residents:
}

Other comments:
Additional money/funding for operations and salaries and qualified staff.

We need more office and transit staff (drivers and dispatchers). In order to hire and maintain qualified staff, we need more money for salary and benefits to attract qualified candidates. Currently, we struggle to get qualified applicants. HR challenges have increased.

In addition to us, Public Transit, there are several taxis and oil field buses in operation. Concern is that taxis operating are not licensed in the city and may not be operating professionally with a high level of safety and customer service standards.

Overall, the struggle is financial. We need to operate in a professional manner and we need funding to increase salaries. In addition, there is a need for security cameras on vehicles and building for our growing community and influx of people for oil/industry related jobs. We can't compete with oil field salaries. It is a challenge remaining open from 6:45 am to 10:00 pm every day of the year (with early closing on holidays)for management. Job burnout is a concern for management. There is also a need for funding for more vehicles. 


\section{Fargo: Metro Area Transit}

Counties:

Service provided: $\quad$ Fixed-route; Door-to-door

\section{Service Data}

\section{Fixed-Route}

Total trips:

Vehicles:

Vehicle miles:

Vehicle hours:

Operating expense:

\section{Demand-Response}

Total trips:

Vehicles:

Vehicle miles:

Vehicle hours:

Operating expense:

Facilities:

Maintenance:

Storage:

Administrative:

Needed upgrades:

\section{Services needed: \\ Challenges: \\ Staffing needs: \\ Meeting needs of residents:}

Other comments:

\section{$1,682,267$}

32

927,601

73,730

$\$ 5,631,208$

53,426

14

344,491

25,822

$\$ 1,376,785$

Metro Transit Garage - 55,000 sq feet, can store up to 50 buses.

Metro Transit Garage - see above (maint and storage are in same facility)

Metro Transit Garage houses most admin staff, Ground Transportation Center houses Fixed-Route dispatch and is the main transfer facility for routes plus the main facility for passengers.

Upgrades include more space for vehicles (maintenance and storage); passenger facility needs further space to handle large numbers of passengers and expanded capacity for transferring vehicles.

New door-to-door service; New fixed-route service; New intercity service; Expansion of currently available services; Weekend service; Longer hours of service long term dedicated source of funding and medicaid reimbursement for other lift transportation providers

More maintenance staff, more drivers and dispatchers, more admin staff.

there are more unmet needs in the community based on input from riders and various studies; expanded hours, more routes to serve growing areas, more lift equipped transportation is a high need

Funding is always a challenge for operating and capital - there is not a long term dedicated resource - this impacts planning and operations. 


\section{Glen Ullin Transportation}

\begin{tabular}{lc} 
Counties: & \multicolumn{2}{l}{ Morton } \\
Service provided: & Curb-to-curb; Door-to-door \\
2013 Service Data & 709 \\
Total trips: & 1 \\
Vehicles: & 5,061 \\
Vehicle miles: & 308 \\
Vehicle hours: & $\$ 10,842$ \\
Operating expense: & \\
Facilities: & Local mechanic or Harlow in Bismarck \\
Maintenance: & City garage \\
Storage: & City office and home \\
Administrative: & Bus wash \\
Needed upgrades: & Substitute driver
\end{tabular}

\section{Golden Valley/Billings Council on Aging}

Counties: $\quad$ Golden Valley, Billings

\section{Service Data}

Total trips:

2,901

Vehicles:

3

Vehicle miles:

90,844

Vehicle hours:

3,720

Operating expense: $\quad \$ 134,216$ 


\section{Grand Forks: Cities Area Transit}

$\begin{array}{ll}\text { Counties: } & \text { Grand Forks } \\ \text { Service provided: } & \text { Fixed-route; Door-to-door }\end{array}$

\section{Service Data}

\section{Fixed-Route}

Total trips:

Vehicles:

Vehicle miles:

Vehicle hours:

Operating expense:

Demand-Response

Total trips:

Vehicles:

Vehicle miles:

Vehicle hours:

Operating expense:

Facilities:

Maintenance:

Storage:

Administrative:

Needed upgrades:

Services needed:

Challenges:

Staffing needs:
364,317

\section{1}

382,632

25,124

$\$ 1,908,557$

52,551

9

190,734

20,110

$\$ 957,102$
City of Grand Forks owns the building which does the maintenance and fueling for the Fixed-Route and Demand-Response vehicle of the cities and helps other transit properties in the region with maintenance and repairs as needed.

City of Grand Forks owns the building which does store all 21 Fixed-Route and Demand-Response vehicles inside. It also stores shop vehicles and equipment for snow removal for the department.

City of Grand Forks owns the building which has the offices for the dispatching and drivers and for the office staff to handle coordinated transportation. The current building is in need of major renovation and rehab. The current facility was built in 1982 and has exceeded its capacity for office space and vehicle storage and maintenance. The current facility has a very poor HVAC system and lighting, is very energy efficient, and needs more office space for expanded service and coordination with other agencies in the area. New fixed-route service; Expansion of currently available services; Weekend service; Longer hours of service Funding. As the demand continually rises we are not able to afford and the lack of qualified drivers and staff to do the jobs.

Additional drivers for paratransit services and Fixed-Route. Additional dispatchers and training staff. 
Meeting needs of residents:

Other comments:
Adequately to poor as the need for expanded service and hours of service is always being asked for by passengers and the business to get people to and from work and shopping.

We have the need of providing service to expanding areas of the city for employment, shopping and medical. The need for service on Sundays has been listed as a priority along with longer service hours. Do to the greater demand for service and expansion of the city, we have a severe lack of Federal, State, and local funding. 


\section{Handi-Wheels Transportation}

Counties: Cass

Service provided: Door-to-door

\section{Service Data}

Total trips:

Vehicles:

Vehicle miles:
10,845

4

59,418

\section{Facilities:}

Maintenance:

Handi-Wheels leases three buses from the City of Fargo. All maintenance on these vehicles are done by the city garage. Handi-Wheels owns one bus and we purchase gas from Ted's Tesoro in Fargo. Adrian's Auto does maintenance on this vehicle.

Storage: Three buses are stored in the garage owned by the Fargo Park District. HandiWheels pays $\$ 60.00$ per space for three spaces or $\$ 180.00$ per month for storage of the three buses. One vehicle is not stored indoors during the summer months. Arrangements have yet to be made for the storage of the fourth bus for this coming winter.

Administrative: Handi-Wheels office is located within the New Horizons Manor building which is a public housing facility owned and managed by Fargo Housing \&

Redevelopment Authority. This office space is granted to Handi-Wheels.

Needed upgrades: Handi-Wheels office is very small. We could use a space double in size due to the fact that our office staff are primarily volunteers who use wheelchairs. No plans are in place to rectify this situation.

Services needed: $\quad$ Expansion of currently available services; Weekend service; Longer hours of service

Challenges:

Cost of hiring drivers for extended hours/ weekend service. Fuel and maintenance costs.

Staffing needs:

Within the next three years, two of our office staff will have completed their jobs training program through Experience Works. This program is state and federally funded. Handi-Wheels is very interested in hiring both of these program participants. We are currently unable to make that offer to either of them. We are currently writing grants to cover the cost of general operating expenses. Within the next five years, we can reasonably expect to hire at least two drivers to replace the aging drivers we currently employ.

\section{Meeting needs of residents:} I believe there is a growing population of people in need of demand-response paratransit transportation services. Handi-Wheels is a very small private, nonprofit organization with limited revenue streams to expand our services in the Fargo and West Fargo communities.

Other comments: Handi-Wheels works with North Dakota Medical Assistance to cover the cost of rides to and from medical appointments for passengers who qualify for Medicaid services. Handi-Wheels is currently being reimbursed at a rate of $\$ 12.93$ per one-way ride. The actual cost of a one-way ride is $\$ 21.92$. 


\section{Hazen Busing}

\begin{tabular}{lr} 
Counties: & \multicolumn{1}{l}{ Mercer, Oliver } \\
Service provided: & Curb-to-curb \\
2013 Service Data & \\
Total trips: & 20,732 \\
Vehicles: & 4 \\
Vehicle miles: & 34,714 \\
Vehicle hours: & 2,840 \\
Operating expense: & $\$ 133,999$
\end{tabular}

\section{Facilities:}

Maintenance: $\quad$ Maintenance conducted by local service facilities

Storage: $\quad$ City owned facilities. Capacity for two buses at each location.

Administrative: $\quad$ Office space provided in city hall. One workspace cubicle.

Needed upgrades: As our fleet grows we would like to have additional in-door space to keep the vehicles out of weather extremes. We may be able to use a space currently owned by the city but it will require updates to meet our needs.

\section{Staffing needs: We currently have sufficient staff but if service increases any amount the staffing will also need to increase. \\ Meeting needs of We currently serve the needs of our area well and this can be improved with residents: continued coordination among the area service providers.}




\section{$\underline{\text { James River Senior Citizens }}$}

Counties: $\quad$ Stutsman, Wells, Sheridan

Service provided: Door-to-door

\section{Service Data}

Total trips:

Vehicles:

Vehicle miles:

Vehicle hours:

Operating expense:
68,585

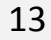

213,764

16,563

$\$ 657,131$

\section{Facilities:}

Maintenance: $\quad$ Private local mechanic shops. We do competitive quotes for all maintenance over $\$ 500.00$.

Storage: $\quad$ We own a 13 vehicle storage facility on the SE part of town. FTA, State and Local dollars financed this building built in 2003.

Administrative: $\quad$ We have all admin offices and dispatch located close to our downtown area. We rent space from LSS. We are a multi service agency providing Public Transportation and Senior meals and tons of fundraising for match dollars for both programs

Needed upgrades: We relocated about a year ago to be closer to downtown. We left our storage facility in the SE part of town. We would love to have our storage facility closer to downtown as the city maintains this area better and in a timely manner. We can get our buses out of that garage but to get moving on a stormy wintery day that area is the last to be cleaned and we battle the city fathers every winter about this issue.

Services needed: $\quad$ New door-through-door or escort service; Longer hours of service

Challenges: financial means. Insurance issues going through the door. Jamestown could use a door through door escort service for many of our riders. We don't have the time or money to provide that type of service.

\section{Staffing needs:}

Bus operators are needed. I put ad in paper I get applicants that don't even have a current license. Work force in our area is terrible. I get people that want no evenings no weekends etc all holidays off.

\section{Meeting needs of residents:} We just changed our evenings hours to close at $7 \mathrm{pm}$ instead of $9 \mathrm{pm}$ as we are not receiving calls after $6 \mathrm{pm}$. We cut back to one driver after $1 \mathrm{pm}$ on Sundays. Our rides are down this transit year. People don't have money to ride. Our fare has been $\$ 2.50$ since 1999

Other comments: Medicaid funding always waiting for our reimbursement. Hard to wait for Federal and State reimbursement some years you may operate for almost 5 months while you wait for your money. 


\section{Kenmare Wheels \& Meals}

\begin{tabular}{|c|c|}
\hline Counties: & Ward (city of Kenmare only) \\
\hline Service provided: & Door-to-door \\
\hline \multicolumn{2}{|l|}{2013 Service Data } \\
\hline Total trips: & 7,648 \\
\hline Vehicles: & 2 \\
\hline Vehicle miles: & 5,994 \\
\hline Vehicle hours: & 1,291 \\
\hline $\begin{array}{l}\text { Operating } \\
\text { expense: }\end{array}$ & $\$ 53,644$ \\
\hline \multicolumn{2}{|l|}{ Facilities: } \\
\hline Maintenance: & Use local garages \\
\hline Storage: & Our own bus garage \\
\hline Administrative: & Our own offices \\
\hline $\begin{array}{l}\text { Meeting needs of } \\
\text { residents: }\end{array}$ & $\begin{array}{l}\text { Service is excellent considering size of community. Lacking evening service } \\
\text { except for work rides. }\end{array}$ \\
\hline Other comments: & There is no dialysis service from our rural area to dialysis treatment center. \\
\hline
\end{tabular}

\section{Kidder/Emmons Senior Services}

Counties:

\section{Service Data}

Total trips:

Vehicles:

Vehicle miles:

Vehicle hours:

Operating expense:
8,739

4

48,702

1,785

Kidder, Stutsman

$\$ 79,713$ 


\section{Minot City Transit}

\section{Counties: Ward \\ Service provided: Traditional fixed-route}

2013 Service Data

Total trips:

Vehicles:

Vehicle miles:

Vehicle hours:

Operating expense:
128,456

15

224,614

17,590

$\$ 677,988$

\section{Facilities:}

Maintenance: $\quad$ Maintenance is performed in the cities vehicle maintenance shop by a mechanic that is assigned to the bus department

Storage: $\quad$ Storage is attached to the maintenance shop and has room for 12 buses

Administrative: $\quad$ Administrative functions are performed in offices located in the vehicle maintenance shop

Needed upgrades: We are in need of a downtown Fixed-Route transfer facility.

Services needed: $\quad$ Expansion of currently available services; Weekend service; Longer hours of service

Challenges: $\quad$ Currently the major challenge is staffing. Very difficult for a municipality to compete with oil field and private companies wages making it difficult to hire and retain drivers.

Staffing Needs: Noted above. 


\section{Nelson County Transit}

Counties: Nelson and rural Grand Forks

Service provided: Door-to-door

2013 Service Data

Total trips: $\quad 5,087$

Vehicles: $\quad 2$

Vehicle miles: $\quad 40,188$

Vehicle hours: $\quad 1,538$

Operating expense: $\quad \$ 106,389$

Meeting needs of We drive up to 7 days a week especially during the summer months. We are residents: making 3 trips a week to Grand Forks for dialysis, other medical and other appointments now. One day a week to Devils Lake for appointments and other reasons, one day a month to Fargo, and one day a week in-county, plus extra trips as well.

Other comments: $\quad$ Advertising and getting out information about this necessary service. 


\section{Northwest Dakota Public Transit}

\begin{tabular}{|c|c|}
\hline Counties: & Divide, McKenzie, Williams \\
\hline Service provided: & Curb-to-curb \\
\hline \multicolumn{2}{|l|}{2013 Service Data } \\
\hline Total trips: & 41,290 \\
\hline Vehicles: & 9 \\
\hline Vehicle miles: & 147,585 \\
\hline Vehicle hours: & 20,872 \\
\hline Operating expense: & $\$ 650,390$ \\
\hline \multicolumn{2}{|l|}{ Facilities: } \\
\hline Maintenance: & 1 NORTH BAY FOR MAINTENANCE \\
\hline Storage: & 3 NORTH BAY AND 2 SOUTH BAY FOR OUR VEHICAL STORAGE \\
\hline Administrative: & $\begin{array}{l}3 \text { OFFICES } 1 \text { FOR DISPATCH } 1 \text { FOR COORDINATOR } 1 \text { DRIVERS } \\
\text { BLDG IS OWNED BY HERITAGE CENTER }\end{array}$ \\
\hline \multicolumn{2}{|l|}{ Needed upgrades: } \\
\hline Services needed: & New fixed-route service; Longer hours of service \\
\hline Challenges: & Funding, need for larger buses, more employees, higher wages \\
\hline Staffing needs: & More drivers and mechanics \\
\hline
\end{tabular}




\section{Nutrition United/Rolette County Transportation}

Counties:

Rolette

\section{Service Data}

Total trips:

7,485

Vehicles:

5

Vehicle miles:

86,913

Vehicle hours:

4,861

Operating expense:

$\$ 100,463$

\section{Pembina County Meals \& Transportation}

Counties:

\section{Service provided:}

\section{Service Data}

Total trips:

Vehicles:

Vehicle miles:

Vehicle hours:

Operating expense:
Throughout Pembina County and for Pembina County residents to Grafton, Park River, Grand Forks, Fargo and Hallock MN.

Door-to-door
4

101,350

4,851

$\$ 158,841$

\section{Facilities:}

Maintenance:

Storage:

Administrative:

Needed upgrades:

Services needed:

Challenges:

Staffing Needs:

Meeting needs of residents:
We hire all of our maintenance from local mechanics.

We rent indoor space during the winter months and vehicles are outside during the summer months.

We rent office space at a senior center for our main office in Drayton, and also rent a small office in Cavalier for drivers and transit supervisor.

We would like to build two parking facilities for vehicles-one in Drayton and one in Cavalier. This is where the vehicles are located. We may need designated office space for a dispatcher in the future.

Weekend service; More trips to regional medical centers

Adequate staffing and funding to hire more staffing.

We need at least one full time driver

We get many requests to regional medical centers for days that we are not scheduled to go there. 


\section{Senior Meals \& Services, Inc.}

Counties: $\quad$ Eddy, Ramsey

Service provided: Door-to-door

\section{Service Data}

Total trips:

Vehicles:

Vehicle miles:

Vehicle hours:

Operating

expense:

\section{Facilities:}

Maintenance:

Storage:

Administrative:

Needed upgrades:

\section{Services needed:}

Staffing needs:

Meeting needs of residents:

Other comments:
29,472

\section{5}

$$
55,723
$$

$$
6,778
$$

$\$ 221,065$

We outsource all maintenance

3 buses are stored in heated garage, 1 bus is stored in unheated garage, and 2 vans sit outside year round.

Administrative functions include but not limited to: dispatching, driving, grant writing, fund raising, computerized data entry, scheduling, training

(presenting and receiving), record keeping, reports

Weekends and nights for customers needing lift rides

All drivers are over 60 and will be looking to retire again

During week day transit hours needs are met very well. Outside of business hours there is no transportation with lifts or in some areas there is no service available at all.

Newer vehicles is always an issue. Trying to find the funding to purchase new vehicles is difficult. Good, honest, reliable drivers is getting more difficult to find. 


\section{Souris Basin Transportation}

Counties: $\quad$ Burke, Renville, Mountrail, Ward, Bottineau, Pierce, and McHenry

Service provided: Curb-to-curb

2013 Service Data

Total trips:

Vehicles:

Vehicle miles:

Vehicle hours:

Operating expense: $\quad \$ 1,099,952$

81,480

23

353,592

27,328
Own. 6875 sq. ft. Includes training room, storage, mechanics office, break room, maintenance pit, storage, wash bay.

Storage: $\quad$ Own. 7500 Square ft. Storage.

Administrative: $\quad$ Own. 2625 sq. ft. Administrative offices.

Needed upgrades: Administrative offices will be too small for adding additional office spaces and dispatching. Storage is limited, next 2-5 years, will need additional vehicle space. Do need 4 small town garages to store our present satellite fleet.

Services needed: New fixed-route service; Expansion of currently available services; Longer hours of service

Finding drivers.

4-12 drivers. 2-4 dispatchers/office admin.

Very limited Fixed-Route system in Minot. Need expansion of services, routes, hours, etc. Rural system is limited to lack of drivers. 


\section{South Central Adult Services}

Counties:

Service provided: Door-to-door

2013 Service Data

Total trips:

Vehicles:

Vehicle miles:

Vehicle hours:

Operating expense: $\quad \$ 1,058,126$

112,665

31

652,751

49,389
Facilities:

Maintenance: $\quad$ All maintenance is provided by outside venders.

Storage: $\quad$ We have a bus garage in Valley City that houses 11 vehicles. The remaining 19 vehicles are located throughout the counties and there are no garages.

Administrative: $\quad$ Administrative offices are located in the Senior Center in Valley City.

Services needed: $\quad$ Expansion of currently available services; Weekend service

Challenges: Inadequate funding, limited vehicles and difficulty in finding drivers.

Staffing needs:

The majority of our employees are near or past retirement age. We will need administrative and direct service staff in the near and distant future.

Meeting needs of residents:

Other comments:
I feel we are meeting the needs, but not necessarily the wants of our residents. There are many things we could do if funding were available.

We are constantly facing increasing costs to provide service and the available funding has not increased to match the costs. We keep having to come up with more and more local/private funding just to maintain where we are at. 


\section{Southwest Public Transit}

Counties:

Service provided:

2013 Service Data

Total trips:

Vehicles:

Vehicle miles:

Vehicle hours:

Operating expense:
Adams, Bowman, Hettinger, Slope

Door-to-door

\section{Facilities:}

Maintenance: $\quad$ Contract out maintenance, no facility.

Storage: $\quad 1$ of 7 stored in rented garage, all others stored outside

Administrative: $\quad$ Rent 3 offices in 3 locations within 4 counties.

Needed upgrades: Need garage space in Bowman. Looking at applying for a grant to house transit offices and garage space within Rec. Center expansion. \$1.4 million project would be transit's portion.

Services needed: $\quad$ Expansion of currently available services

Challenges: Many people still think we are for seniors only. Marketing to get the word out that we are for the public.

Staffing needs: $\quad$ It is difficult to find and keep good drivers in this western ND economy. We have raised wages above the normal raises to keep our drivers after their initial starting wage, up to $\$ 2$ per hour within one year. This is an expense we did not intend on for the immediate, but will allow for the future.

Meeting needs of We have not received any complaints.

residents:

Other comments: We need garage facilities for our vehicles in our counties. 


\section{Spirit Lake Senior Services}

$\begin{array}{lr}\text { Counties: } & \text { Benson, Ramsey } \\ \text { Service provided: } & \text { Curb-to-curb } \\ 2012 \text { Service Data } & \\ \text { Total trips: } & 2,576 \\ \text { Vehicles: } & 8 \\ \text { Vehicle miles: } & 24,323 \\ \text { Vehicle hours: } & 960 \\ \text { Operating expense: } & \$ 67,705\end{array}$

Facilities:

Storage: Garage

Staffing needs: $\quad$ Need 1-2 more drivers.

Other comments: Need new vehicles with lifts. 


\section{Standing Rock Public Transit}

Service provided:

2013 Service Data

Total trips:

Vehicles:

Vehicle miles:

Vehicle hours:

Operating expense:
Sioux, Morton, Burleigh

Fixed-route; Curb-to-curb

Facilities:

Maintenance: $\quad 5,000$ square feet used for maintenance $\&$ storage

Storage:

Administrative: $\quad 2,500$ square feet

Services needed: $\quad$ New door-to-door service; New fixed-route service; Weekend service; Longer hours of service

Challenges:

Rural residences, extreme distances from basic services

Meeting needs of

Due to location and time we are not able to provide the same types of services residents: for every community. For instance, we are unable to transport passengers from Solen to Fort Yates.

Other comments: $\quad$ There is a great need for additional services to transport commuters from Bismarck/Mandan to Fort Yates for employment purposes due to the lack of housing in Sioux County. Securing matching funds is becoming a greater issue as the cost of providing transit continues to increase. 


\section{Trenton Indian Services Area}

\section{Counties: Williams}

2012 Service Data

Total trips: $\quad 2,764$

Vehicles: 6

Vehicle miles: $\quad 49,608$

Vehicle hours: $\quad 6,384$

Operating expense: $\quad \$ 69,728$

\section{Turtle Mountain Transit}

Counties: Rolette

\section{Service Data}

Total trips:

249

Vehicles:

3

Vehicle miles:

38,283

Operating expense: $\quad \$ 150,995$ 


\section{Valley Senior Services}

Counties:

Service provided:

2013 Service Data

Total trips:

Vehicles:

Vehicle miles:

Vehicle hours:

Operating expense:
Cass, Traill, Steele, Richland, Ransom, Sargent and Grand Forks

Door-to-door

395,225

29,295

$\$ 360,958$

\section{Facilities:}

Maintenance: $\quad$ We use local repair shops for vehicle maintenance.

Storage: $\quad$ We rent local garages in the counties we serve.<break>ln Fargo metro we own a vehicle storage facility.

Administrative: $\quad$ Main office located in Fargo with satellite offices in Hillsboro, Lisbon and Wahpeton.

Staffing needs: Will need to hire 10 more drivers and 1 additional dispatcher in next two years.

Meeting needs of We provide a quality service with relatively few turn downs at the present. residents: The demand for more service will continue in the urban area and the challenge will be to provide good service with limited funds and adequate staffing challenges. 


\section{Walsh County Transportation}

Counties:

Service provided: Curb-to-curb; Door-to-door

2013 Service Data

Total trips:

Vehicles:

Vehicle miles:

Vehicle hours:

Operating expense:
Walsh, Pembina, Grand Forks

\section{3}

62,308

3,567

$\$ 140,832$

\section{Facilities:}

Storage:

Administrative:

Needed upgrades:

Services needed:

Challenges:

Staffing needs:

Meeting needs of residents:

Other comments:
Rent a pole barn to store 4 vehicles

Rent office space

Possible heated bus barn

Expansion of currently available services; Longer hours of service

Money, drivers, staff

More drivers, dispatch

We don't have a lot of calls for rides that we can't meet but maybe different people would ride with more services.

Younger drivers, ours are all 65+, since it is a part-time job, heated bus barn would be nice and another "ramp" bus not one with a lift but a ramp. 


\section{West River Transit}

Counties: $\quad$ Eastern Burleigh, Morton, Oliver, Mercer, McLean, Dunn, Grant

Service provided: Curb-to-curb; Door-to-door

2013 Service Data

Total trips:

Vehicles:

Vehicle miles:

Vehicle hours:

Operating expense:
30,644

14

152,667

9,641

$\$ 615,985$

\section{Facilities:}

Maintenance: $\quad$ no maintenance facilities

Storage: $\quad$ all four facilities are for vehicle storage

Administrative: None

Needed upgrades: None

Services needed: $\quad$ Weekend service

Challenges:

Available drivers

Staffing needs: $\quad$ need for one additional office staff, and drivers 


\section{Wildrose Public Transportation}

Counties: Williams, Divide

Service provided: Door-to-door

2013 Service Data

Total trips: 200

Vehicles: $\quad 1$

Vehicle miles: $\quad 6,324$

\section{Facilities:}

Maintenance: $\quad$ Go to the Ford dealer in Minot

Storage: $\quad 1$ vehicle garage owned by transportation

Administrative: $\quad$ My house

Challenges: Having someone to drive

Staffing needs: $\quad$ Could use a few more drivers that are available more often

Meeting needs of We are usually able to get a trip done for the ones that really need the residents: $\quad$ transportation, others have the option to drive or ride with someone else if the van can't take them 


\section{APPENDIX G. COMMENTS FROM TRANSIT AGENCIES}

Table G.1 Challenges to Providing New Services

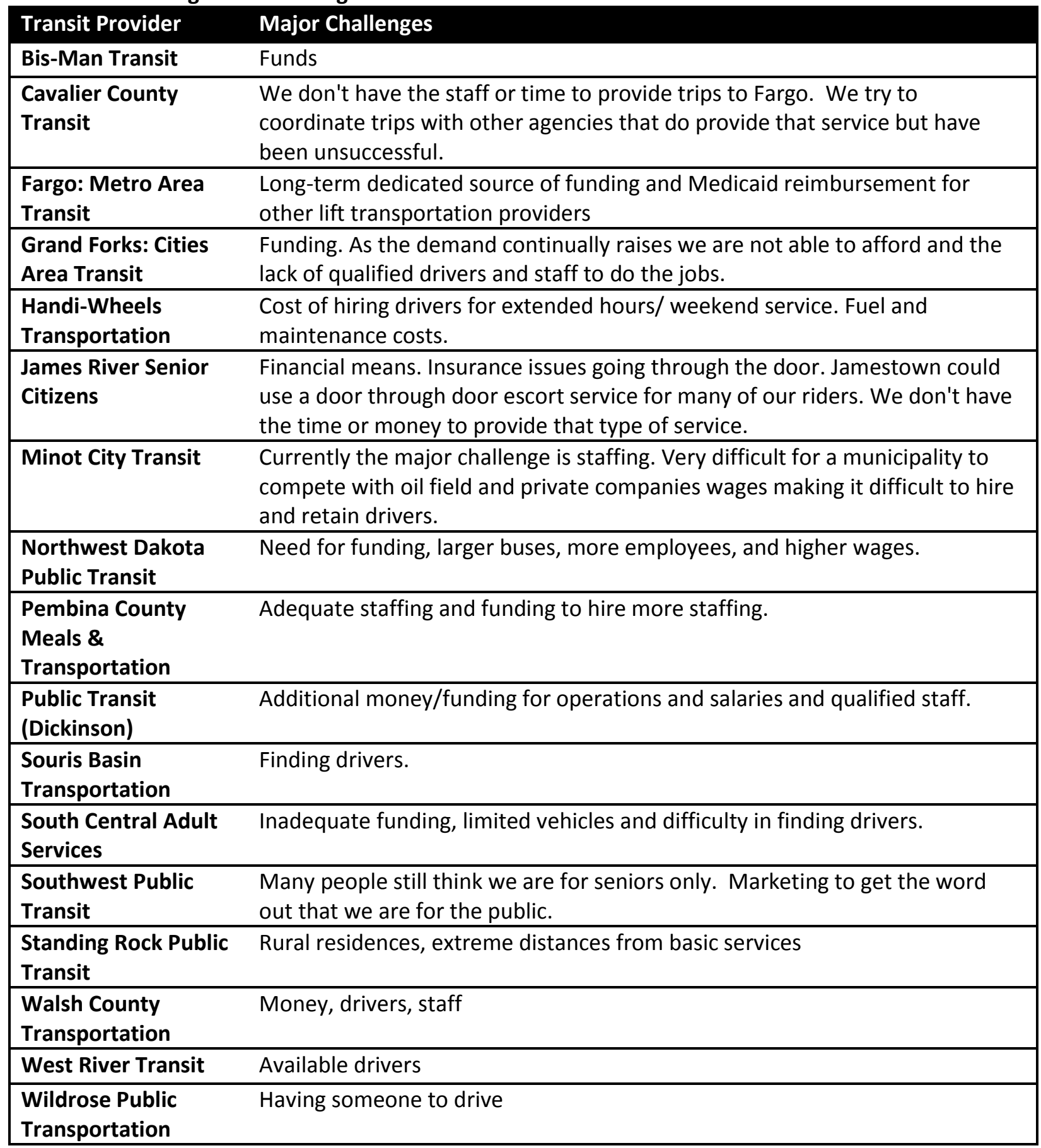


Table G.2 Staffing Needs

\begin{tabular}{|c|c|}
\hline Transit Agency & Staffing Need \\
\hline $\begin{array}{l}\text { Benson County } \\
\text { Transportation }\end{array}$ & $\begin{array}{l}\text { More staff needed if in the future we do more transportation on the } \\
\text { reservation. }\end{array}$ \\
\hline Cavalier County Transit & Currently we have 1 full-time driver, 1 part-time driver and 3 substitutes. \\
\hline $\begin{array}{l}\text { Dickey County } \\
\text { Transportation }\end{array}$ & $\begin{array}{l}\text { If demand increases, then we would need to add driver hours and/or drivers as } \\
\text { current drivers are part time. }\end{array}$ \\
\hline Fargo: Metro Area Transit & More maintenance staff, more drivers and dispatchers, more admin staff. \\
\hline $\begin{array}{l}\text { Grand Forks: Cities Area } \\
\text { Transit }\end{array}$ & $\begin{array}{l}\text { Additional drivers for paratransit services and Fixed-Route. Additional } \\
\text { dispatchers and training staff. }\end{array}$ \\
\hline $\begin{array}{l}\text { Handi-Wheels } \\
\text { Transportation }\end{array}$ & $\begin{array}{l}\text { Within the next three years, two of our office staff will have completed their } \\
\text { jobs training program through Experience Works. This program is state and } \\
\text { federally funded. We are very interested in hiring both of these program } \\
\text { participants but are currently unable to make an offer to either of them. We are } \\
\text { currently writing grants to cover the cost of general operating expenses. Within } \\
\text { the next five years, we expect to hire at least two drivers to replace the aging } \\
\text { drivers we currently employ. }\end{array}$ \\
\hline $\begin{array}{l}\text { Hazen Transit/City of } \\
\text { Hazen }\end{array}$ & $\begin{array}{l}\text { We currently have sufficient staff but if service increases any amount the } \\
\text { staffing will also need to increase. }\end{array}$ \\
\hline Glen Ullin Transportation & Substitute driver \\
\hline $\begin{array}{l}\text { James River Senior } \\
\text { Citizens }\end{array}$ & $\begin{array}{l}\text { Bus operators are needed. I put an ad in paper, and I get applicants that don't } \\
\text { even have a current license. I get people that want no evenings, no weekends, } \\
\text { etc., all holidays off. }\end{array}$ \\
\hline $\begin{array}{l}\text { Northwest Dakota Public } \\
\text { Transit }\end{array}$ & Need more drivers and a mechanic. \\
\hline $\begin{array}{l}\text { Pembina County Meals \& } \\
\text { Transportation }\end{array}$ & We need at least one full time driver \\
\hline Public Transit (Dickinson) & $\begin{array}{l}\text { We need more office and transit staff (drivers and dispatchers). In order to hire } \\
\text { and maintain qualified staff, we need more money for salary and benefits to } \\
\text { attract qualified candidates. Currently, we struggle to get qualified applicants. } \\
\text { HR challenges have increased. }\end{array}$ \\
\hline $\begin{array}{l}\text { Senior Meals \& Services } \\
\text { Inc. (Devils Lake/Eddy Co. } \\
\text { Transit) }\end{array}$ & All drivers are over 60 and will be looking to retire again \\
\hline $\begin{array}{l}\text { Souris Basin } \\
\text { Transportation }\end{array}$ & 4-12 drivers. 2-4 dispatchers/office admin. \\
\hline $\begin{array}{l}\text { South Central Adult } \\
\text { Services }\end{array}$ & $\begin{array}{l}\text { The majority of our employees are near or past retirement age. We will need } \\
\text { administrative and direct service staff in the near and distant future. }\end{array}$ \\
\hline Southwest Public Transit & $\begin{array}{l}\text { It is difficult to find and keep good drivers in this western ND economy. We } \\
\text { have raised wages above the normal raises to keep our drivers after their initial } \\
\text { starting wage, up to } \$ 2 \text { per hour within one year. This is an expense we did not } \\
\text { intend on for the immediate, but will allow for the future. }\end{array}$ \\
\hline Spirit Lake Senior Serv. & Need 1-2 more drivers. \\
\hline Valley Senior Services & Will need to hire 10 more drivers and 1 dispatcher in next two years. \\
\hline Walsh County Trans. & More drivers, dispatch \\
\hline West River Transit & need for one additional office staff, and drivers \\
\hline Wildrose Public Trans. & more drivers that are available more often \\
\hline
\end{tabular}


Table G.3 Comments on How Well Transportation Needs of Service Area Residents are Being Met

\begin{tabular}{|c|c|}
\hline Transit Agency & Comment \\
\hline Bis-Man Transit & e well but we need to work on our on-time performance. \\
\hline $\begin{array}{l}\text { Cavalier County } \\
\text { Transit }\end{array}$ & $\begin{array}{l}\text { We are able to pick people up before and after business hours for medical appointments } \\
\text { when necessary. }\end{array}$ \\
\hline $\begin{array}{l}\text { Dickey County } \\
\text { Transportation }\end{array}$ & $\begin{array}{l}\text { I am sure there are gaps - but what are the additional continuing needs? We do not seem to } \\
\text { get requests for ongoing services. We do not fill the occasional one person wants to go } \\
\text { somewhere once requests that we sometimes get. }\end{array}$ \\
\hline $\begin{array}{l}\text { Fargo: Metro Area } \\
\text { Transit }\end{array}$ & $\begin{array}{l}\text { There are more unmet needs in the community based on input from riders and various } \\
\text { studies; expanded hours, more routes to serve growing areas, more lift equipped } \\
\text { transportation is a high need }\end{array}$ \\
\hline $\begin{array}{l}\text { Grand Forks: Cities } \\
\text { Area Transit }\end{array}$ & $\begin{array}{l}\text { Adequately to poor as the need for expanded service and hours of service is always being } \\
\text { asked for by passengers and the business to get people to and from work and shopping. }\end{array}$ \\
\hline $\begin{array}{l}\text { Handi-Wheels } \\
\text { Transportation }\end{array}$ & $\begin{array}{l}\text { I believe there is a growing population of people in need of demand-response paratransit } \\
\text { transportation services. Handi-Wheels is a very small private, non-profit organization with } \\
\text { limited revenue streams to expand our services in the Fargo and West Fargo communities. }\end{array}$ \\
\hline $\begin{array}{l}\text { Hazen Transit/City o } \\
\text { Hazen }\end{array}$ & $\begin{array}{l}\text { We currently serve the needs of our area well and this can be improved with continued } \\
\text { coordination among the area service providers. }\end{array}$ \\
\hline $\begin{array}{l}\text { James River Senior } \\
\text { Citizens }\end{array}$ & $\begin{array}{l}\text { We just changed our evening hours to close at } 7 \mathrm{pm} \text { instead of } 9 \mathrm{pm} \text { as we are not receiving } \\
\text { calls after } 6 \mathrm{pm} \text {. We cut back to one driver after } 1 \mathrm{pm} \text { on Sundays. Our rides are down this } \\
\text { year. People don't have money to ride. Our fare has been } \$ 2.50 \text { since } 1999 \text {. }\end{array}$ \\
\hline $\begin{array}{l}\text { Kenmare Wheels \& } \\
\text { Meals }\end{array}$ & $\begin{array}{l}\text { Service is excellent considering size of community. Lacking evening service except for work } \\
\text { rides. }\end{array}$ \\
\hline \begin{tabular}{|l|} 
Nelson County \\
Transit
\end{tabular} & $\begin{array}{l}\text { We drive up to } 7 \text { days a week especially during the summer months. We are making } 3 \text { trips } \\
\text { a week to Grand Forks for dialysis, other medical and other appointments now. One day a } \\
\text { week to Devils Lake for appointments and other reasons, one day a month to Fargo, and } \\
\text { one day a week in-county, plus extra trips as well. }\end{array}$ \\
\hline $\begin{array}{l}\text { Pembina Co. Meals \& } \\
\text { Transportation }\end{array}$ & $\begin{array}{l}\text { We get many requests to regional medical centers for days that we are not scheduled to go } \\
\text { there. }\end{array}$ \\
\hline $\begin{array}{l}\text { Public Transit } \\
\text { (Dickinson) }\end{array}$ & $\begin{array}{l}\text { In addition to us, Public Transit, there are several taxis and oil field buses in operation. } \\
\text { Concern is that taxis operating are not licensed in the city and may not be operating } \\
\text { professionally with a high level of safety and customer service standards. }\end{array}$ \\
\hline $\begin{array}{l}\text { Senior Meals \& } \\
\text { Services Inc. (Devils } \\
\text { Lake/Eddy County) }\end{array}$ & $\begin{array}{l}\text { During week day transit hours needs are met very well. Outside of business hours there is } \\
\text { no transportation with lifts or in some areas there is no service available at all. }\end{array}$ \\
\hline \begin{tabular}{|l|} 
Souris Basin \\
Transportation \\
\end{tabular} & $\begin{array}{l}\text { Very limited fixed-route system in Minot. Need expansion of services, routes, hours, etc. } \\
\text { Rural system is limited to lack of drivers. }\end{array}$ \\
\hline $\begin{array}{l}\text { South Central Adult } \\
\text { Services }\end{array}$ & $\begin{array}{l}\text { I feel we are meeting the needs, but not necessarily the wants of our residents. There are } \\
\text { many things we could do if funding were available. }\end{array}$ \\
\hline $\begin{array}{l}\text { Standing Rock Public } \\
\text { Transit }\end{array}$ & $\begin{array}{l}\text { Due to location and time we are not able to provide the same types of services for every } \\
\text { community. For instance, we are unable to transport passengers from Solen to Fort Yates. }\end{array}$ \\
\hline \begin{tabular}{|l|} 
Valley Senior \\
Services
\end{tabular} & $\begin{array}{l}\text { We provide a quality service with relatively few turn downs at the present. The demand for } \\
\text { more service will continue in the urban area and the challenge will be to provide good } \\
\text { service with limited funds and adequate staffing challenges. }\end{array}$ \\
\hline $\begin{array}{l}\text { Walsh County } \\
\text { Transportation }\end{array}$ & $\begin{array}{l}\text { We don't have a lot of calls for rides that we can't meet but maybe different people would } \\
\text { ride with more services. }\end{array}$ \\
\hline $\begin{array}{l}\text { Wildrose Public } \\
\text { Transportation }\end{array}$ & $\begin{array}{l}\text { We are usually able to get a trip done for the ones that really need the transportation, } \\
\text { others have the option to drive or ride with someone else if the van can't take them }\end{array}$ \\
\hline
\end{tabular}


Table G.4 Additional Comments from Transit Agencies

\begin{tabular}{|c|c|}
\hline Transit Agency & Comment \\
\hline Bis-Man Transit & Funds for both operating and capital. \\
\hline $\begin{array}{l}\text { Dickey County } \\
\text { Transportation }\end{array}$ & $\begin{array}{l}\text { This rural county has a lot of services and businesses in the county - more } \\
\text { compared to surrounding counties which seems to lessen the need/desire to } \\
\text { go out of county to access services. }\end{array}$ \\
\hline $\begin{array}{l}\text { Fargo: Metro Area } \\
\text { Transit }\end{array}$ & $\begin{array}{l}\text { Funding is always a challenge for operating and capital - there is not a long } \\
\text { term dedicated resource - this impacts planning and operations. }\end{array}$ \\
\hline $\begin{array}{l}\text { Grand Forks: Cities } \\
\text { Area Transit }\end{array}$ & $\begin{array}{l}\text { We have the need of providing service to expanding areas of the city for } \\
\text { employment, shopping and medical. The need for service on Sundays has } \\
\text { been listed as a priority along with longer service hours. Due to the greater } \\
\text { demand for service and expansion of the city, we have a severe lack of } \\
\text { Federal, State, and local funding. }\end{array}$ \\
\hline $\begin{array}{l}\text { Handi-Wheels } \\
\text { Transportation }\end{array}$ & $\begin{array}{l}\text { Handi-Wheels works with North Dakota Medical Assistance to cover the cost } \\
\text { of rides to and from medical appointments for passengers who qualify for } \\
\text { Medicaid services. Handi-Wheels is currently being reimbursed at a rate of } \\
\$ 12.93 \text { per one-way ride. The actual cost of a one-way ride is } \$ 21.92 \text {. }\end{array}$ \\
\hline $\begin{array}{l}\text { James River Senior } \\
\text { Citizens }\end{array}$ & $\begin{array}{l}\text { Medicaid funding always waiting for our reimbursement. Hard to wait for } \\
\text { Federal and State reimbursement some years you may operate for almost } 5 \\
\text { months while you wait for your money. }\end{array}$ \\
\hline $\begin{array}{l}\text { Kenmare Wheels \& } \\
\text { Meals }\end{array}$ & There is no dialysis service from our rural area to dialysis treatment center. \\
\hline Nelson County Transit & Advertising and getting out information about this necessary service. \\
\hline $\begin{array}{l}\text { Public Transit } \\
\text { (Dickinson) }\end{array}$ & $\begin{array}{l}\text { Overall, the struggle is financial. We need to operate in a professional manner } \\
\text { and we need funding to increase salaries. In addition, there is a need for } \\
\text { security cameras on vehicles and building for our growing community and } \\
\text { influx of people for oil/industry related jobs. We can't compete with oil field } \\
\text { salaries. It is a challenge remaining open from 6:45 am to 10:00 pm every day } \\
\text { of the year (with early closing on holidays) for management. Job burnout is a } \\
\text { concern for management. }\end{array}$ \\
\hline $\begin{array}{l}\text { Senior Meals \& } \\
\text { Services Inc. (Devils } \\
\text { Lake/Eddy County } \\
\text { Transit }\end{array}$ & $\begin{array}{l}\text { Newer vehicles is always an issue. Trying to find the funding to purchase new } \\
\text { vehicles is difficult. Good, honest, reliable drivers is getting more difficult to } \\
\text { find. }\end{array}$ \\
\hline $\begin{array}{l}\text { South Central Adult } \\
\text { Services }\end{array}$ & $\begin{array}{l}\text { We are constantly facing increasing costs to provide service and the available } \\
\text { funding has not increased to match the costs. We keep having to come up } \\
\text { with more and more local/private funding just to maintain where we are at. }\end{array}$ \\
\hline $\begin{array}{l}\text { Southwest Public } \\
\text { Transit }\end{array}$ & We need garage facilities for our vehicles in our counties. \\
\hline $\begin{array}{l}\text { Spirit Lake Senior } \\
\text { Services }\end{array}$ & We need new vehicles with lifts. \\
\hline $\begin{array}{l}\text { Standing Rock Public } \\
\text { Transit }\end{array}$ & $\begin{array}{l}\text { There is a great need for additional services to transport commuters from } \\
\text { Bismarck/Mandan to Fort Yates for employment purposes due to the lack of } \\
\text { housing in Sioux County. Securing matching funds is becoming a greater issue } \\
\text { as the cost of providing transit continues to increase. }\end{array}$ \\
\hline $\begin{array}{l}\text { Walsh County } \\
\text { Transportation }\end{array}$ & $\begin{array}{l}\text { Younger drivers, ours are all 65+, since it is a part-time job, heated bus barn } \\
\text { would be nice and another "ramp" bus, not one with a lift but a ramp. }\end{array}$ \\
\hline
\end{tabular}

